UNIVERSIDADE DE SÃO PAULO

FACULDADE DE ZOOTECNIA E ENGENHARIA DE ALIMENTOS

ALEXANDRE ROSIM PEREIRA

Painéis sanduíche com faces de placas de fibrocimento e núcleo de painéis de partículas de subprodutos agroindustriais

Pirassununga 
ALEXANDRE ROSIM PEREIRA

Painéis sanduíche com faces de placas de fibrocimento e núcleo de painéis de partículas de subprodutos agroindustriais

(Versão Corrigida)

Dissertação apresentada à Faculdade de Zootecnia e Engenharia de Alimentos da Universidade de São Paulo, como parte dos requisitos para a obtenção do Título de Mestre em Ciências do Programa de Pós-graduação em Engenharia e Ciências de Materiais.

Área de Concentração: Desenvolvimento, Caracterização e Aplicação de Materiais Voltados à Agroindústria.

Orientador: Prof. Dr. João Adriano Rossignolo Coorientador: Prof. Dr. Juliano Fiorelli

Pirassununga 
Ficha catalográfica elaborada pelo

Serviço de Biblioteca e Informação, FZEA/USP, com os dados fornecidos pelo(a) autor(a)

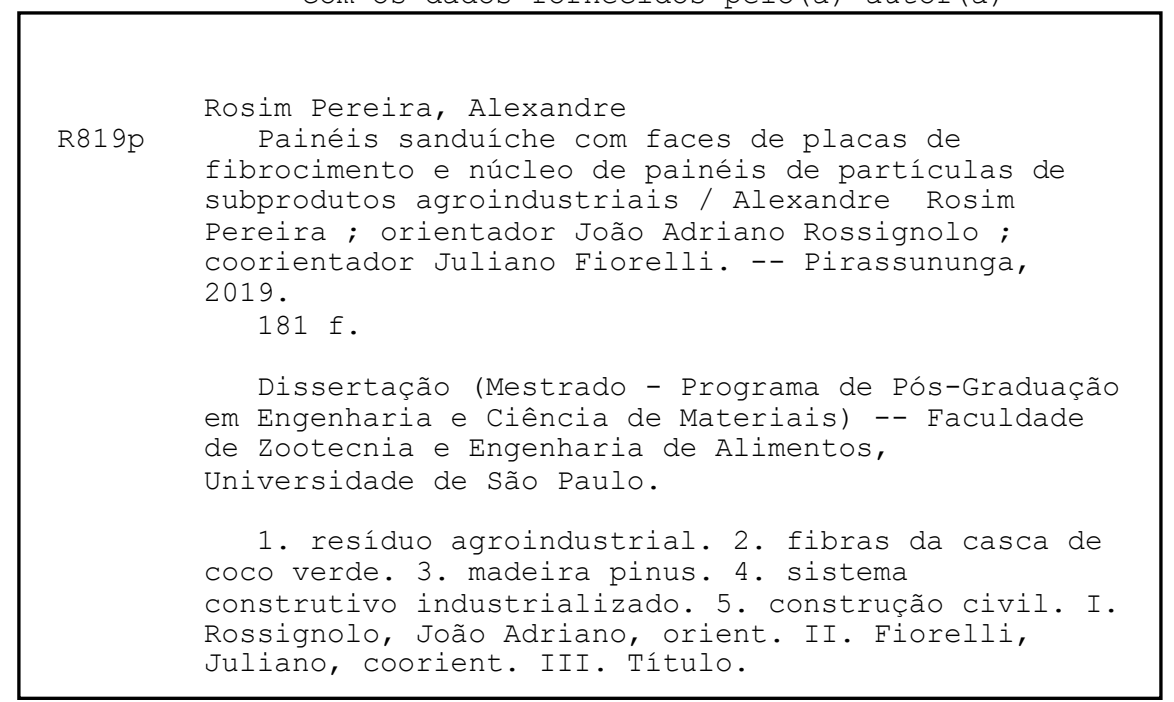

Permitida a cópia total ou parcial deste documento, desde que citada a fonte - o autor 


\section{ALEXANDRE ROSIM PEREIRA \\ Painéis sanduíche com faces de placas de fibrocimento e núcleo de painéis de partículas de subprodutos agroindustriais}

Dissertação apresentada à Faculdade de Zootecnia e Engenharia de Alimentos da Universidade de São Paulo, como parte dos requisitos para a obtenção do Título de Mestre em Ciências, do Programa de Pós-graduação em Engenharia e Ciências de Materiais.

Data de aprovação: -------------/ 2019.

Banca examinadora:

Prof. Dr.

Instituição:

Presidente da Banca Examinadora

Prof. Dr (a).

Instituição:

Prof. Dr (a).

Instituição:

Prof. Dr.

Instituição:

Pirassununga

2019 


\section{AGRADECIMENTOS}

Ao Professor Doutor João Adriano Rossignolo pela oportunidade de trabalhar com essa pesquisa pelo seu equilíbrio em todas as situações que surgiram e em alguns momentos sabe que não foram fáceis. Agradeço pela sua serenidade, bom humor e palavras de motivação. Foi uma honra ser seu orientado e parceiro de trabalho.

Ao Professor Doutor Juliano Fiorelli por toda delicadeza e paciência, que ao me coorientar demonstrou dedicação e confiança. Fiquei honrado pela sua ajuda para completar mais uma etapa da minha vida.

À Professora Doutora Rosimery Aparecida de Carvalho que sempre me incentivou a iniciar essa jornada, que participou de momentos difíceis de minha vida pessoal e sempre tinha uma palavra de conforto.

Ao Grupo Infibra (Infibra S/A) sediada em Leme, São Paulo e a empresa HolamGrow (Holamgrow Comércio e Beneficiamento de Fibras Vegetais Ltda) instalada em Holambra, São Paulo, pelo apoio durante essa pesquisa.

Aos colegas e técnicos do Laboratório de Construções Rurais e Ambiência.

Aos meus colegas de trabalho e sociedade da MacCann Engenharia. 


\section{DEDICATÓRIA}

Aos meus primeiros amores,

Minha mãe, grande "cuidadora”, Maria Onilde Rosim Pereira, professora e amiga, me ensinou a cozinhar, a respeitar e olhar para sua religião e fé, sempre demonstrou a importância da família e me permitiu todos os tipos de brincadeiras e aventuras;

Meu pai “in memoriam”, Wandir Palma Pereira, sábio “construtor”, que infelizmente começou a ler minha pesquisa, mas não pode terminar. Desde minha adolescência rotineiramente desfrutava horas diárias de leitura e com essa atitude incentiva todos de casa a ler, mesmo sem conseguir convencer a todos para o bom hábito adorava este passa tempo. Hoje fico com esta imagem e com saudades o admiro ainda mais. Entre muitas boas histórias, contava a de um filósofo que quando perguntado por que lia tanto respondia, eu quero o saber.

Minha esposa Carolina Cabianca Ramos por tudo que reconstruímos e construímos juntos.

Meus filhos Luca Ramos Pereira e Murilo Ramos Pereira atualmente com sete anos, pelo tempo que deixei de estar e brincar com vocês, para que pratiquem a ciência, se dediquem aos estudos e aos esportes como seu papai.

Amo vocês e muito obrigado! 


\section{RESUMO}

ROSIM PEREIRA. A. Painéis sanduíche com faces de placas de fibrocimento e núcleo de painéis de partículas de subprodutos agroindustriais.

2019. 181 f. Dissertação (Mestrado) - Faculdade de Zootecnia e Engenharia de alimentos, Universidade de São Paulo, Pirassununga, São Paulo, 2019.

O presente trabalho propôs o estudo de desempenho de painéis sanduíche formados por núcleo de painéis de partículas de fibras da casca de coco verde e de madeira pinus, Pinus sp., conformado por placas de fibrocimento de forma a produzir um compósito com propriedades associadas. Os painéis sanduíche foram avaliados por ensaio físico e mecânico, determinaram-se a densidade média de cada tratamento e as tensões de face e núcleo dos painéis sanduíche. Termicamente foram avaliados por equações analíticas e analisados por requisitos normativos. Inicialmente foram analisadas as propriedades físicas das matérias primas e dos componentes das faces e do núcleo. A placa de fibrocimento que compôs as faces foi analisada por ensaios físicos, mecânicos e térmico. Os resultados das propriedades foram comparados com referências normativas e de empresas que fabricam e avaliam produtos de fibrocimento similares. Para a produção dos painéis aglomerados de partículas que formaram os núcleos utilizou-se a fibra da casca de coco verde, Cocos nucifera, em substituição parcial as partículas de madeira pinus, Pinus sp., na proporção de $30 \%$ e $70 \%$ respectivamente. $\mathrm{O}$ adesivo utilizado nos painéis de subprodutos da agroindústria foi a resina poliuretana bicomponente à base de óleo de mamona. Foram produzidos e avaliados painéis com três densidades, sendo $350 \mathrm{~kg} / \mathrm{m}^{3}$ (baixa), $600 \mathrm{~kg} / \mathrm{m}^{3}$ (média) e $850 \mathrm{Kg} / \mathrm{m}^{3}$ (alta). Os painéis de partículas foram avaliados por ensaios físicos, mecânicos e térmico. Como parâmetro de comparação de resultados um painel comercial de média densidade MDP foi avaliado da mesma forma. Os resultados dos testes de todos componentes e dos painéis sanduíches produzidos, foram comparados e analisados em atendimento às normas que os regem e com produtos comercializados nos setores da construção civil. A partir dos resultados concluiu-se que os painéis sanduíche com núcleo de subprodutos da agroindústria apresentaram propriedades similares ao painel sanduíche com núcleo de MDP comercial e aos painéis sanduíche de vedação produzido por empresas da indústria da construção civil. $\mathrm{O}$ estudo demonstrou a potencialidade técnica da possível aplicação do painel sanduíche como componente ou elemento em sistemas construtivos na construção civil.

Palavras-chave: resíduo agroindustrial, fibras da casca de coco verde, madeira pinus, sistema construtivo industrializado, construção civil. 


\begin{abstract}
ROSIM PEREIRA. A. Sandwich panels with faces of fiber-cement flat sheets and particleboard core of agro-industrial by-products.

2019. 181 f. Dissertação (Mestrado) - Faculdade de Zootecnia e Engenharia de alimentos, Universidade de São Paulo, Pirassununga, São Paulo, 2019.

The present work proposes the study of sandwich panel performance formed by homogeneous particleboard panels of green coconut shell fibers and pinus wood particles, coated with nonasbestos cement flat sheets in order to produce a composite with associated properties. The sandwich panel was evaluated by physical and mechanical tests. The physical test determined the density mean of each treatment, and the mechanical test obtained the sandwich panels face and core tensions, thermally was evaluated by analytical equations and analyzed by standards requirements. Firstly, the physical properties of the raw materials of the facings and cores were analyzed according to the standard requirements. The fiber cement board that composed the faces was tested in physical, mechanical and thermal tests. The results of the properties tested were compared with references of technical standards and manufactured similar industrial products in accordance with current standards for cementitious products. For the production of the panels, the fiber of the green coconut shell, Cocos nucifera, was used in partial substitution of the pine wood particles, Pinus sp., in the proportion of $30 \%$ and $70 \%$ respectively. The adhesive used in the panels of agro-industry by-products was the bicomponent resin based on castor oil. Panels with densities ranging from low $350 \mathrm{~kg} / \mathrm{m}^{3}$, medium $600 \mathrm{~kg} / \mathrm{m}^{3}$ and high $850 \mathrm{~kg} / \mathrm{m}^{3}$ were produced. The particleboards were evaluated by mechanical, physical and thermal tests. As a parameter of comparison of results a MDP medium density commercial panel (density between $551 \mathrm{Kg} / \mathrm{m}^{3}$ and $750 \mathrm{~kg} / \mathrm{m}^{3}$ ) was tested in the same conditions. The results of the tests of all constituent components and the sandwich panels and were compared and analyzed in compliance with the current standards and commercial products market in the construction sectors. The results concluded that the sandwich panel particleboard core made by-products of agro-industry presented similar properties of the sandwich panel of commercial MDP core and those from construction industrial products. The study demonstrated that the technical capability of the possible application of the sandwich panel as a component or element in constructive systems of the civil construction.
\end{abstract}

Keywords: agroindustrial residue, green coconut shell fibers, pine wood, industrialized building system, construction. 


\section{LISTA DE FIGURAS}

Figura 1 - Sistema construtivo de vedação vertical em placas de gesso Drywall

Figura 2 - Vedação vertical com placas de fibrocimento - Drywall .......................26

Figura 3 - Sistema construtivo de vedação vertical em painéis de concreto ..............27

Figura 4 - Centro de produção de sistema de vedação industrializado

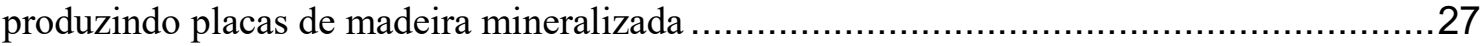

Figura 5 - Sistema pré-moldado de vedação vertical em blocos cerâmicos ...............28

Figura 6 - Sistema construtivo de vedação vertical em GRC .............................29

Figura 7 - Sistema construtivo estrutural em madeira tipo plataforma Wood Frame 30

Figura 8 - Sistema Wood Frame com painéis de partículas OSB ...........................30

Figura 9 - Sistema Steel Frame com painéis de partículas OSB ............................31

Figura 10 - Constituição do fruto do coqueiro anão verde ..................................37

Figura 11 - Aeronave produzida em painel sanduíche ....................................49

Figura 12 - Painel sanduíche com sistema caixão perdido ….............................50

Figura 13 - Painel sanduíche com núcleo celular........................................51

Figura 14 - Exemplos de núcleos para painéis sanduíche ...............................53

Figura 15 - Painéis sanduíche e tipos de núcleos canelados ..............................53

Figura 16 - Painéis sanduíches aplicados como cobertura ...............................58

Figura 17 - Painel sanduíche com núcleo de madeira balsa para plataforma de ponte

Figura 18 - Ponte Bex montada em painel sanduíche com núcleo de madeira balsa

Figura 19 - Painel sanduíche polimérico reforçado com fibra de vidro para cobertura......

Figura 20 - Exemplo de aplicação do painel sanduíche de fibras de madeira como forro isolante térmico em instalação rural ....

Figura 21 - Painel sanduíche de núcleo ES com aplicação para isolação térmica 
Figura 22 - Sistema S.I.P de construção residencial em madeira e painéis

Figura 23 - Painel sanduíche Eternit com núcleo em madeira laminada e faces de fibrocimento 64

Figura 24 - Painel sanduíche com núcleo em poliestireno expandido e faces de fibrocimento

Figura 25 - Sistema construtivo a seco para escada e pisos de painéis sanduíche

Figura 26 - Painel sanduíche com núcleo de madeira reconstituída 68

Figura 27 - Configurações padrão de carga (Standard and Non-Standard Configuration)

Figura 28 - Configuração de carga quatro pontos para painel sanduíche .74

Figura 29 - Representação das dimensões em espessura de um tipo de painel sanduíche

Figura 30 - Fluxograma das atividades desenvolvidas no trabalho de pesquisa

Figura 31 - Fluxograma das atividades desenvolvidas para o estudo do painel sanduíche.

Figura 32 - Picador com malha para classificação primária das matérias primas

Figura 33 - Estufa com circulação de ar para a preparação das matérias primas

Figura 34 - Balança eletrônica digital com amostra de fibra de coco verde..... .90

Figura 35 - Aparelho Multipicnômetro com amostra de maravalha da madeira de pinus

Figura 36 - Estufa para secagem das partículas de madeira pinus e fibras de coco verde.

Figura 37 - Conjunto de peneiras sobre agitador para classificação granulométrica das matérias primas

Figura 38 - Etapas de processamento para a fabricação dos painéis aglomerado de subprodutos da agroindústria 96

Figura 39 - Serra elétrica de bancada para preparação de corpos de prova 98 
Figura 40 - Câmara climática com amostras dos painéis aglomerados de subprodutos da agroindústria e MDP comercial para estabilização 100

Figura 41 - Amostras de painéis aglomerado de subprodutos da agroindústria e MDP comercial submersas. 102

Figura 42 - Máquina universal de ensaios mecânicos EMIC 104

Figura 43 - Corpo de prova do painel aglomerado de subprodutos da agroindústria posicionado na máquina universal EMIC durante ensaio de flexão 104

Figura 44 - Corpo de prova de painel MDP comercial ensaiado no bloco de tração 106

Figura 45 - Corpo de prova de painel aglomerado de subprodutos da agroindústria em ensaio de arranque de parafuso na superfície e no topo.

Figura 46 - Equipamento de medição de condutividade térmica DTC-300 .............109

Figura 47 - Serra de corte para materiais cimentícios.....................................110

Figura 48 - Amostras da placa de fibrocimento submersas ...............................112

Figura 49 - Amostra da placa de fibrocimento em pesagem imersa.....................113

Figura 50 - Resina PU nas faces da placa de fibrocimento .............................117

Figura 51 - Resina aplicada sobre as faces dos painéis de partículas aglomeradas de subprodutos da agroindústria e painel MDP comercial....

Figura 52 - Painéis sanduíche compostos por núcleo de painéis aglomerados de partículas de subprodutos da agroindústria e MDP comercial com faces de placa de fibrocimento após prensagem

Figura 53 - Perfil do painel sanduíche formado por núcleo de painel aglomerado de partículas de subprodutos da agroindústria com faces de placa de fibrocimento e espessura aproximada de um dos corpos de prova

Figura 54 - Posicionamento do corpo de prova do painel sanduíche com núcleo de painéis de partículas de subprodutos da agroindústria e placas de fibrocimento na configuração de carga em três pontos e durante ensaio de flexão chegando à ruptura

Figura 55 - Curvas de tensão e deformação específica representativos da média de cada tratamento experimental dos painéis de partículas aglomerados.

Figura 56 - Curvas dos ensaios de flexão (MOR) e (MOE) para os painéis sanduíche formados por núcleos de painéis aglomerados de subprodutos da agroindústria e painel MDP comercial com faces de placa de fibrocimento 
Figura 57 - Curva representativa dos seguimentos que descrevem o mapa

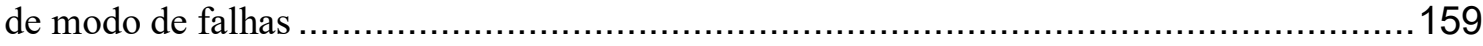

Figura 58 - Curvas do ensaio de tensão máxima de ruptura de cisalhamento de núcleo do painel sanduíche de todos os tratamentos experimentais

Figura 59 - Curvas do ensaio de tensão máxima na face dos painéis sanduíche para todos os tratamentos experimentais

Figura 60 - Curvas do ensaio de tensão de cisalhamento de núcleo dos painéis sanduíche em $2 \%$ de deformação de todos os tratamentos experimentais.

Figura 61 - Amostras de todos os tratamentos experimentais dos painéis sanduíche após ensaios mecânicos de flexão estática para análise das falhas mecânicas 


\section{LISTA DE QUADROS}

Quadro 1 - Eficiência estrutural do painel sanduíche em razão da espessura t.....

Quadro 2 - Características físicas do painel sanduíche ...................................65

Quadro 3 - Ensaios realizados e características físicas do painel sanduíche ..............66

Quadro 4 - Cargas máximas de utilização do painel sanduíche .............................67

Quadro 5 - Especificações do painel sanduíche com faces de fibrocimento para mezanino e laje seca

Quadro 6 - Normas referenciadas em algumas pesquisas sobre painel sanduíche

Quadro 7 - Resumo de algumas normas revisadas e avaliadas pelo comitê ASTM D30 no ano de 2009

Quadro 8 - Códigos de identificação das falhas do painel sanduíche na configuração de carga em três pontos

Quadro 9 - Delineamento experimental para os painéis de partículas aglomeradas de subprodutos da agroindústria.

Quadro 10 - Planejamento de corte dos corpos de prova dos painéis de partículas aglomeradas

Quadro 11 - Planejamento de corte dos corpos de prova da placa de fibrocimento.

Quadro 12 - Delineamento experimental para os painéis sanduíche

Quadro 13 - Planejamento de corte dos corpos de prova dos painéis sanduíche 


\section{LISTA DE TABELAS}

Tabela 1 - Teor de umidade média das matérias primas para produção dos painéis de partículas

Tabela 2 - Densidade real média das matérias primas para produção dos painéis de partículas

Tabela 3 - Densidade média dos painéis aglomerado de partículas e fibras e MDP comercial

Tabela 4 - Teor de umidade média dos painéis de partículas e fibras e MDP comercial

Tabela 5 - Inchamento médio da espessura dos painéis de partículas e fibras e MDP comercial

Tabela 6 - MOR e MOE médio dos painéis de partículas e fibras e MDP comercial

Tabela 7 - Resistência á tração perpendicular dos painéis de partículas e fibras e MDP comercial.

Tabela 8 - Resistência ao arranque de parafuso na superfície dos painéis de partículas e fibras e MDP comercial.

Tabela 9 - Resistência ao arranque de parafuso no topo dos painéis de partículas e fibras e MDP comercial.

Tabela 10 - Resistência e condutividade térmica dos painéis de partículas e fibras e MDP comercial.

Tabela 11 - Condutividade térmica de painéis de partículas de fibras lignocelulósicas

Tabela 12 - Absorção de água e porosidade aparente das amostras da placa de fibrocimento

Tabela 13 - Densidade seca e saturada das amostras da placa de fibrocimento.

Tabela 14 - Propriedades mecânicas da placa de fibrocimento: MOR (módulo de resistência à flexão estática), LPO (Limite de proporcionalidade) e MOE (módulo de elasticidade)

Tabela 15 - Resistência e condutividade térmica da placa de fibrocimento

Tabela 16 - Densidade média dos painéis sanduíche, das faces e núcleos

Tabela 17 - Resultados de (MOR) e (MOE) de cada tratamento dos painéis sanduíche... 
Tabela 18 - Resultado médio da Tensão máxima de cisalhamento de

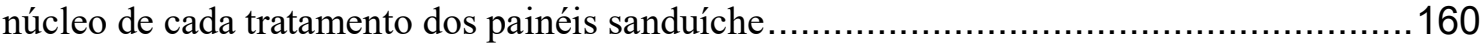

Tabela 19 - Resultado médio da tensão máxima nas faces de cada

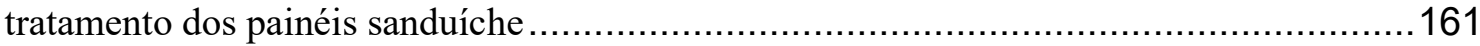

Tabela 20 - Resultado médio da tensão de cisalhamento de núcleo de cada tratamento dos painéis sanduíche em $2 \%$ de deformação .............................................163

Tabela 21 - Resistência e condutividade térmica de cada tratamento dos

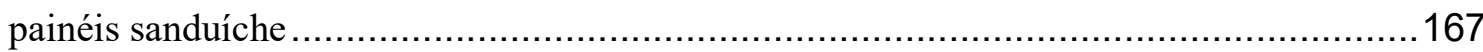




\section{LISTA DE GRÁFICOS}

Gráfico 1 - Medianas e dispersões de resultados de todos os tratamentos experimentais para os ensaios de densidade das amostras dos painéis aglomerado de partículas e fibras e MDP comercial

Gráfico 2 - Medianas e dispersões de resultados de todos os tratamentos experimentais para os ensaios de teor de umidade das amostras dos painéis aglomerado de partículas e fibras e MDP comercial

Gráfico 3 - Medianas e dispersões de resultados de todos os tratamentos experimentais para os ensaios de inchamento em espessura das amostras dos painéis aglomerado de partículas e fibras e MDP comercial

Gráfico 4 - Medianas e dispersões de resultados de todos os tratamentos experimentais para os ensaios de MOR das amostras dos painéis aglomerado de partículas e fibras e MDP comercial

Gráfico 5 - Medianas e dispersões de resultados de todos os tratamentos experimentais para os ensaios de MOE das amostras dos painéis aglomerado de partículas e fibras e MDP comercial

Gráfico 6 - Medianas e dispersões de resultados de todos os tratamentos experimentais para os ensaios de tração perpendicular das amostras dos painéis aglomerado de partículas e fibras e MDP comercial

Gráfico 7 - Medianas e dispersões de resultados de todos os tratamentos experimentais para os ensaios de arranque de parafuso na superfície das amostras dos painéis aglomerado de partículas e fibras e MDP comercial

Gráfico 8 - Medianas e dispersões de resultados de todos os tratamentos experimentais para os ensaios de arranque de parafuso no topo das amostras dos painéis aglomerado de partículas e fibras e MDP comercial 


\section{Sumário}

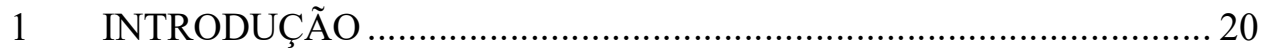

1.1 Justificativa e relevância da pesquisa .......................................... 22

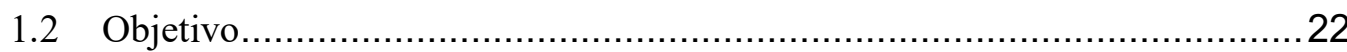

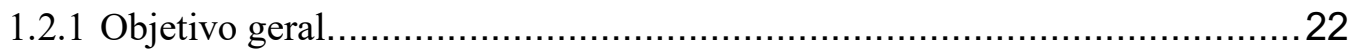

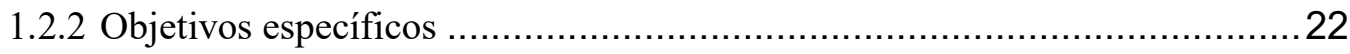

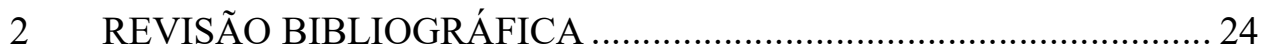

2.1 Opções comerciais de sistemas de vedações vertical industrializadas............24

2.2 Painéis de partículas aglomerados ................................................. 32

2.2.1 Painéis de partículas aglomeradas de madeira ................................... 32

2.2.2 Reaproveitamento dos subprodutos da agroindústria ........................... 35

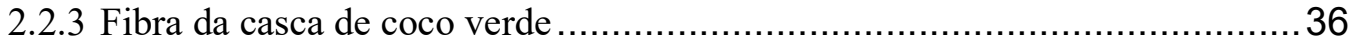

2.2.4 Painéis aglomerados de partículas de subprodutos agroindustriais ...............38

2.2.5 Parâmetros de produção dos painéis de partículas...................................4 41

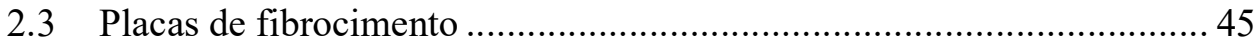

2.3.1 Parâmetros de avaliação comercial para a escolha da placa de fibrocimento .. 45

2.3.2 Parâmetros para a caracterização físico-mecânica da placa de fibrocimento .. 46

2.4 Painéis sanduíche 48

2.4.1 Breve histórico 48

2.4.2 Componentes construtivos e propriedades estruturais do painel sanduíche ....51

2.4.3 Considerações sobre painéis sanduíche disponíveis na indústria da construção

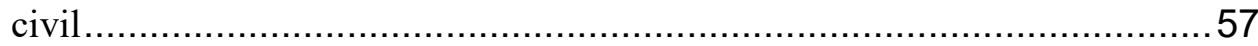

2.4.4 Características e aplicações dos painéis sanduíche no mercado nacional .......63

2.4.5 Especificações dos ensaios em painéis sanduíche: núcleos e faces................69

2.4.6 Significância e propósito da norma ASTM 393/393M - 11 ........................71

2.4.7 Comportamentos mecânico e falhas estruturais de painéis sanduíche............77 
2.4.8 Análises estatísticas 79

2.4.9 Painéis aglomerados de partículas revestidos com placas de fibrocimento: uso de subprodutos da agroindústria

81

3 MATERIAIS E MÉTODOS 83

3.1 Materiais. 84

3.1.1 Painéis de partículas aglomerados de subprodutos da agroindústria 84

3.1.2 Painel de partículas aglomerado constituído de madeira .85

3.1.3 Placas de fibrocimento 85

3.1.4 Painéis sanduíche. 86

3.1.5 Equipamentos 86

3.2 Métodos 88

3.2.1 Caracterização dos materiais: partículas e fibras de subprodutos da agroindústria $\ldots \ldots \ldots \ldots \ldots \ldots \ldots \ldots \ldots \ldots \ldots \ldots \ldots \ldots \ldots \ldots \ldots \ldots \ldots \ldots \ldots \ldots \ldots \ldots . \ldots \ldots$

3.2.2 Processo de produção dos painéis de partículas aglomerados de subprodutos da

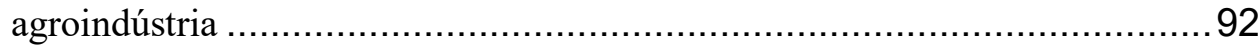

3.2.3 Caracterização física, mecânica e térmica dos painéis de partículas

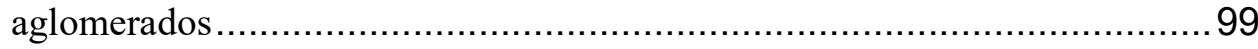

3.2.4 Diretrizes de recebimento da placa de fibrocimento ............................. 110

3.2.5 Caracterização físico-mecânica e térmica da placa de fibrocimento ............ 111

3.2.6 Processo de produção do painel sanduíche..........................................116

3.2.7 Caracterização física, mecânica e térmica do painel sanduíche...................121

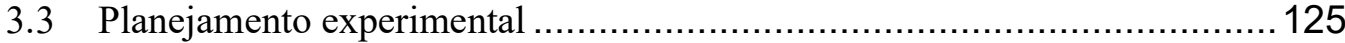

3.3.1 Planejamento estatístico para os ensaios das amostras dos painéis de partículas de subprodutos da agroindústria e MDP 125

3.3.2 Planejamento estatístico para os ensaios das amostras da placa de fibrocimento126 3.3.3 Planejamento estatístico para os ensaios das amostras do painel sanduíche 127 


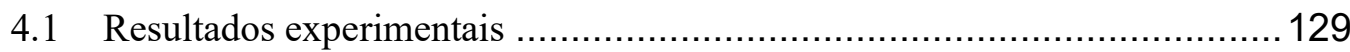

4.2 Apresentação das propriedades físicas, mecânicas e térmicas dos painéis aglomerado de partículas ................................................................ 129

4.2.1 Propriedades físicas ................................................................ 129

4.2.2 Considerações sobre as propriedades físicas ...................................... 137

4.2.3 Propriedades mecânicas........................................................... 138

4.2.4 Considerações sobre as propriedades mecânicas................................ 147

4.2.5 Condutividade e resistência térmica dos painéis de partículas homogêneas .148

4.2.6 Considerações sobre as propriedades térmicas ................................... 150

4.3 Apresentação das propriedades físicas, mecânicas e térmicas da placa de

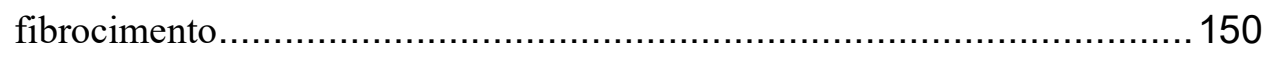

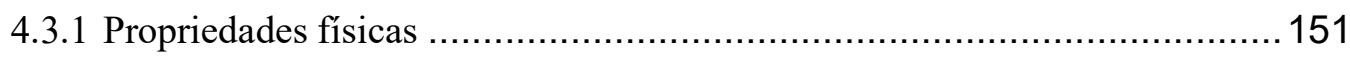

4.3.2 Considerações sobre as propriedades físicas ................................. 152

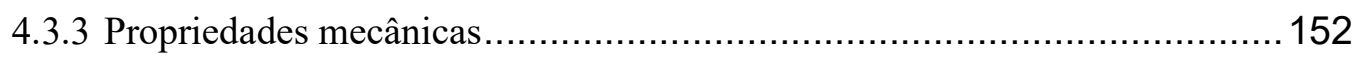

4.3.4 Considerações sobre as propriedades mecânicas............................... 152

4.3.5 Condutividade e resistência térmica das amostras da placa de fibrocimento 153

4.3.6 Considerações sobre as propriedades térmicas ................................... 153

4.4 Apresentação das propriedades físicas, mecânicas e térmicas dos painéis

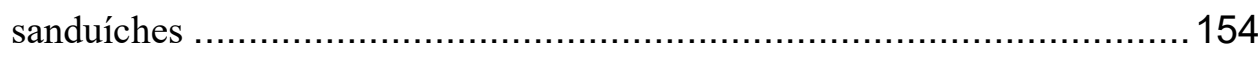

4.4.1 Propriedades físicas dos painéis sanduíche …................................ 154

4.4.2 Considerações sobre as propriedades físicas .................................... 155

4.4.3 Propriedades mecânicas dos painéis sanduíche - ensaio de flexão ............... 156

4.4.4 Considerações sobre os ensaios de flexão ......................................... 164

4.4.5 Falhas mecânicas dos painéis sanduíche ....................................... 165

4.4.6 Considerações sobre as falhas mecânicas......................................... 166 
4.4.7 Condutividade e resistência térmica dos painéis sanduíche

4.4.8 Considerações sobre as propriedades térmicas

5 CONCLUSÕES

170 


\section{INTRODUÇÃO}

As fibras vegetais ou materiais lignocelulósicos são considerados por muitos um resíduo da agroindústria. A disposição final deste subproduto se apresenta como um problema social, econômico e ambiental para muitos países, assim a utilização deste componente como material renovável para aplicação na construção civil pode auxiliar na redução de passivos ambientais. Dessa forma, pesquisas direcionadas na reutilização de materiais lignocelulósicos puderam demonstrar seu potencial para a fabricação de painéis de partículas em substituição parcial à madeira; matéria prima preferida pelas indústrias do Brasil que produzem painéis aglomerados; valorizando o subproduto e direcionando este material para a mesma atividade que a madeira como uma alternativa sustentável (GARZON BARRERO, 2015).

Com o desenvolvimento da construção civil, a produção e a utilização de novos materiais, mais leves e resistentes são crescentes. O uso de compósitos nomeados estruturas sanduíche se expande em diversas aplicações por causa da sua capacidade de combinar alta rigidez à flexão e baixo peso (GAGLIARDO, 2008).

Motta et al. (2016) expõe que o desenvolvimento dos setores da construção civil precisa adotar a necessidade de se utilizar recursos renováveis para a produção de novos materiais. $\mathrm{O}$ uso de compósitos que empregam diferentes fibras vegetais começou a receber considerável atenção de pesquisadores e empresas do setor.

Diante desta evolução, os painéis sanduíche também foram desenvolvidos para serem utilizados como paredes, telhados, forros e pisos. Inicialmente produzidos com faces de madeira compensada, eram coladas sobre enrijecedores longitudinais também de madeira, porém maciça. Posteriormente se desenvolveu um núcleo de papelão tipo "colmeia de abelha", tratado com resina fenólica, funcionando como um verdadeiro sanduíche. Outras composições foram desenvolvidas, muitas delas para obras de interesse social, portanto desenvolver alternativas para contribuir em soluções de problemas existentes no processo de construção de habitações justifica as pesquisas sobre a temática (BERTINI, 2002).

Painéis sanduíche aplicados como componentes de vedação e produzidos com materiais compósitos podem ter razoável desempenho térmico-acústico quando comparado a outros sistemas tradicionais. Além disso, os painéis sanduíche compósitos apresentam elevada relação de resistência e densidade relativa, dessa forma com propriedades adequadas para aplicações em sistemas de vedação. Por essas razões, a utilização dos painéis sanduíche como 
componente de sistemas de vedação vertical tem se tornado tema de pesquisas (ABDOLPOUR, et al., 2017).

Dentro deste contexto, os painéis sanduíche podem ser produzidos por vários materiais, com núcleos compostos de madeiras ou com outras fibras lignocelulósicas, ainda pode representar a oportunidade de se alcançar melhores desempenhos com a aplicação de materiais similarmente eficientes aos convencionais (WAY, et al.,2016).

O fato dos painéis sanduíche demonstrarem uma evolução da tecnologia dos materiais e das técnicas de projeto e execução em relação aos componentes e elementos convencionais aplicados nos sistemas construtivos, não o isenta das patologias da construção. As ocorrências patológicas são responsáveis por uma parcela da manutenção predial, um melhor detalhamento de projeto e escolha de materiais adequados para os sistemas construtivos poderiam evitar grande parte das intervenções de reparo nas habitações (TAGUCHI, 2010).

Assim os componentes e elementos de um sistema construtivo devem apresentar um bom desempenho térmico, físico e mecânico. A norma ABNT NBR 15575-5: 2013 Edificações habitacionais - Desempenho Parte 4: Sistemas de vedações verticais internas e externas - SVVIE aborda, entre outros itens, o atendimento às exigências dos usuários que utilizam uma habitação, apresenta critérios e requisitos de desempenho e durabilidade para a vida útil dos sistemas construtivos.

Dessa forma este trabalho apresentou o estudo das propriedades físicas, mecânicas e térmicas dos painéis sanduíche com núcleo de painéis aglomerados de subprodutos da agroindústria com a proposta de agregar valor a estes materiais para serem utilizados como matéria prima e estimular pesquisas que avaliem a potencialidade técnica de produção de novos componentes ou elementos não convencionais para a aplicação nos setores da construção civil. 


\subsection{Justificativa e relevância da pesquisa}

Diante do exposto na introdução e após revisão bibliográfica desta pesquisa, desenvolver e avaliar um painel sanduíche com núcleo de painéis aglomerado de partículas de subprodutos da agroindústria e MDP comercial com faces de placas de fibrocimento tem relevância pelas possíveis contribuições:

* Propõe um destino mais produtivo e agregador aos subprodutos da agroindústria;

* Poder ajudar a impulsionar as pesquisas de produção de painéis de partículas aglomeradas lignocelulósicas diferente da madeira;

* Poder auxiliar na divulgação e desenvolvimento de pesquisas relacionadas aos sistemas construtivos da construção civil que utilizem painéis sanduíche;

* Pode divulgar produtos inovadores e propor um elemento para ser aplicado em um sistema construtivo industrializado.

\subsection{Objetivo}

\subsubsection{Objetivo geral}

Desenvolver e avaliar painel sanduíche composto por núcleo de painéis aglomerado de partículas de fibra da casca de coco verde (Cocos nucifera) e de partículas de madeira pinus (Pinus sp.) e MDP comercial conformado com faces de placa de fibrocimento com vistas à aplicação nos setores da construção civil.

\subsubsection{Objetivos específicos}

Para alcançar o objetivo geral e avaliar as propriedades dos painéis sanduíche foram planejadas as seguintes atividades: 
- Avaliar o desempenho físico, mecânico e térmico de painéis aglomerado de partículas de fibra da casca de coco verde e de madeira pinus, de painel de partículas de madeira (MDP) comercial e de placa de fibrocimento comercial;

- Avaliar o desempenho físico, mecânico e térmico de painéis sanduíche com núcleo de painéis aglomerado de partículas de fibra da casca de coco verde e de madeira pinus e de painel de partículas de madeira (MDP) comercial conformado com faces de placas de fibrocimento comercial. 


\section{REVISÃO BIBLIOGRÁFICA}

O objetivo deste capítulo é apresentar o inicio da divulgação e o emprego dos sistemas industrializados de vedações verticais, as opções comerciais utilizadas nos dias atuais e parte das pesquisas desenvolvidas sobre o tema.

Inicialmente o capítulo descreve um breve histórico sobre os painéis de partículas, sua produção e aplicação. Em seguida expõem-se os estudos relacionados aos painéis aglomerado de partículas, parâmetros de produção e as pesquisas no reaproveitamento de subprodutos da agroindústria para a substituição parcial ou total à madeira.

O texto apresenta os parâmetros de avaliação para a aquisição e caracterização da placa de fibrocimento comercial.

Finalmente os últimos itens contextualizam o histórico dos painéis sanduíches, a evolução e aplicação como material da construção civil. Apresentam-se seus componentes construtivos estruturais, as opções no mercado nacional e internacional, parte das normativas para a caracterização e avaliação das suas propriedades e considerações sobre o comportamento mecânico e falhas estruturais dos painéis sanduíche.

\subsection{Opções comerciais de sistemas de vedações vertical industrializadas}

A Agência Brasileira de Desenvolvimento Industrial (ABDI, 2015) apresenta os principais sistemas de vedação vertical encontrados no mercado brasileiro até o estágio atual. Expõe que o sistema estrutural metálico, que se iniciou no Brasil em 1957, com a construção do edifício garagem América, em São Paulo, com 16 pavimentos, ainda é considerado novo. A estrutura metálica exigiu um sistema de vedação vertical com características particulares, atendendo as exigências da interface entre vedações e estrutura. Atualmente quase todos os sistemas de vedações verticais compatibilizam com a estrutura em aço, inclusive a vedação vertical em componentes cerâmicos. Um dos sistemas mais comuns é o light Steel Framing, empregam os painéis arquitetônicos metálicos de fachada e/ou os painéis metálicos termoacústicos. Estes painéis metálicos termoacústicos são empregados comumente em obras industriais onde se demanda o controle de temperatura, normalmente produzidos em aço com núcleo de material isolante são conhecidos como painéis sanduiche. 
Segundo Holanda (2003), o retorno do sistema de vedação vertical utilizando chapas de gesso cartonado ao mercado ocorreu em 1994 com a constituição da empresa "Drywall", representou uma inovação tecnológica nos sistemas de vedação vertical. Aplicados em edificações residenciais de classe média este sistema é composto por uma estrutura de aço (Steel Framing) onde as placas de gesso são instaladas. $\mathrm{O}$ autor acrescenta que a partir deste ano empresas de outros países ingressaram no mercado, como a francesa Lafarge, a inglesa Placo do Brasil e a alemã Knauf, também a empresa Eucatex que importava produtos dos Estados Unidos da América. No fim da década de 1990 o consumo de placas de gesso cresceu e o sistema de vedação com placas passou a ser adotado em grande escala, aplicados em hotéis, escritórios, residências e Shopping Centres (Figura 1).

Figura 1 - Sistema construtivo de vedação vertical em placas de gesso - Drywall

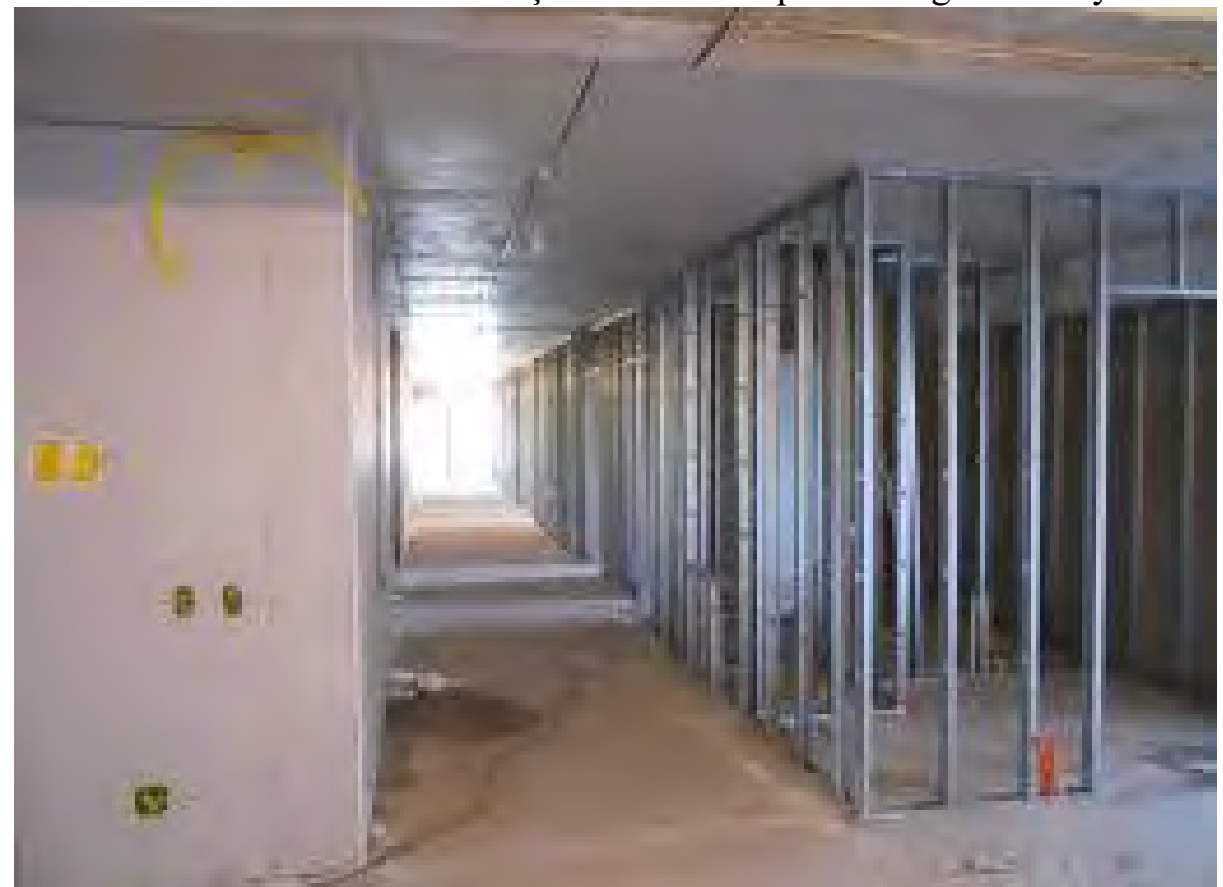

Fonte: Imagens google scholar - www.valefoco.com.br, (2017) - Steel Framing com placa de gesso.

Outra opção de vedo para a estrutura Steel Framing, segundo Fontenelle (2012), é o sistema formado por placas de fibrocimento, considerado como um sistema de vedação leve, com menos de $100 \mathrm{~kg} / \mathrm{m}^{2}$ serve como revestimento interno e externo para edificações, com a possibilidade de aplicar revestimentos utilizando métodos construtivos tradicionais (Figura 2). 
Figura 2 - Vedação vertical com placas de fibrocimento - Drywall

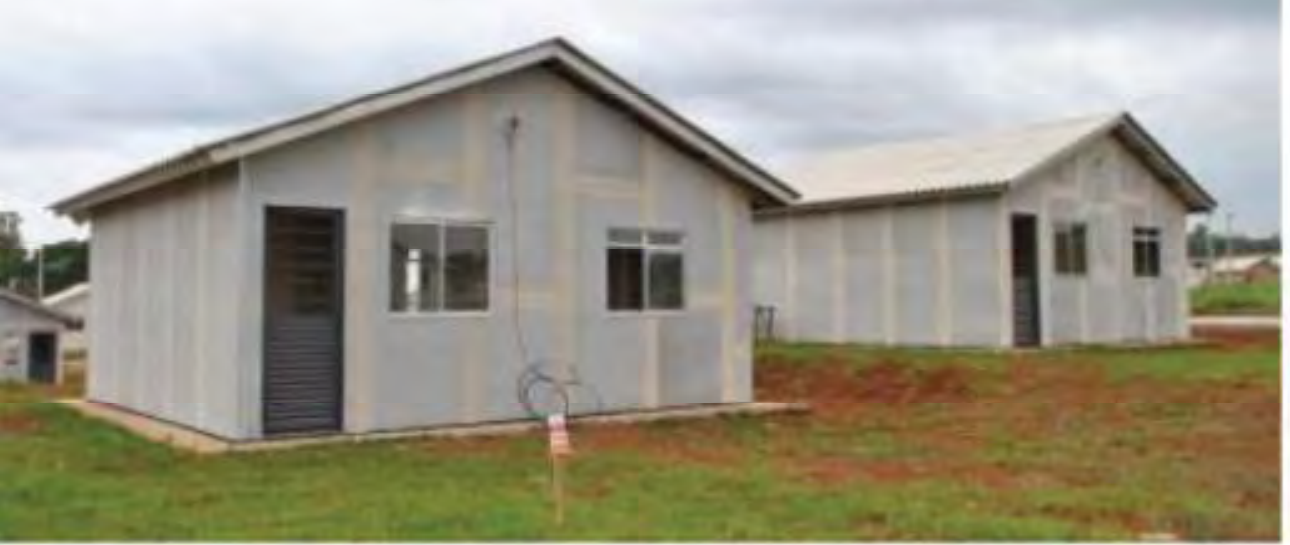

Fonte: Manual da construção industrializada, (ABDI, 2015).

Pereira (2012) descreve o uso de pré-moldados em concreto armado e apresenta o histórico da aplicação da argamassa armada como sistema de vedação vertical a partir da década de 1970. O autor expõe a tendência da construção civil em transferir parte do canteiro de obra para o ambiente de fábrica utilizada como uma base de produção.

Silva e Silva (2004) apresentam no "Manual de Construção em Aço (IBS/CBCA)" os painéis em concreto armado pré-moldados como uma opção para vedação vertical, principalmente utilizado no sistema construtivo estrutural em aço. Os pesquisadores acrescentam que podem ser utilizados como elemento estrutural ou de vedação, são produzidos industrialmente ou no canteiro de obras, possuem acabamentos variados como borracha, textura, pigmentados em cores, com pedras ornamentais ou posteriormente revestidos (INSTITUTO BRASILEIRO DE SIDERURGIA CENTRO BRASILEIRO DA CONSTRUÇÃO EM AÇO, 2004) (Figura 3a e Figura 3b). 
Figura 3 - Sistema construtivo de vedação vertical em painéis de concreto

(a)

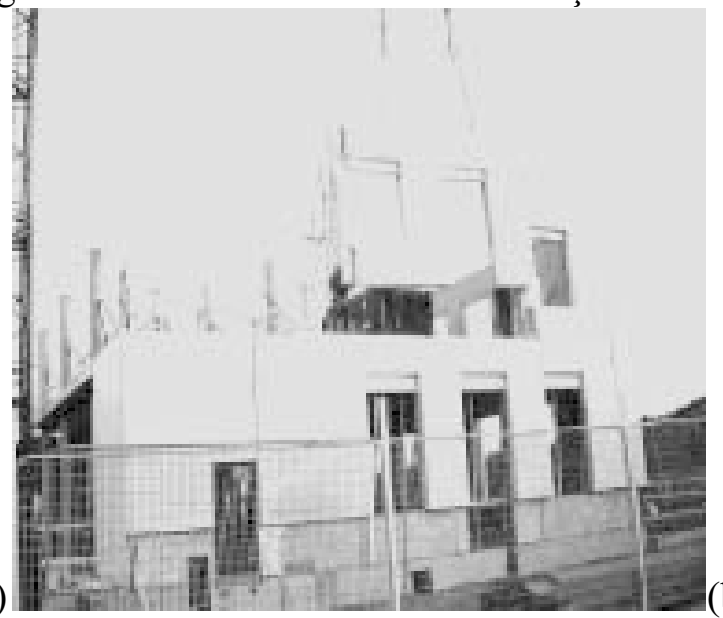

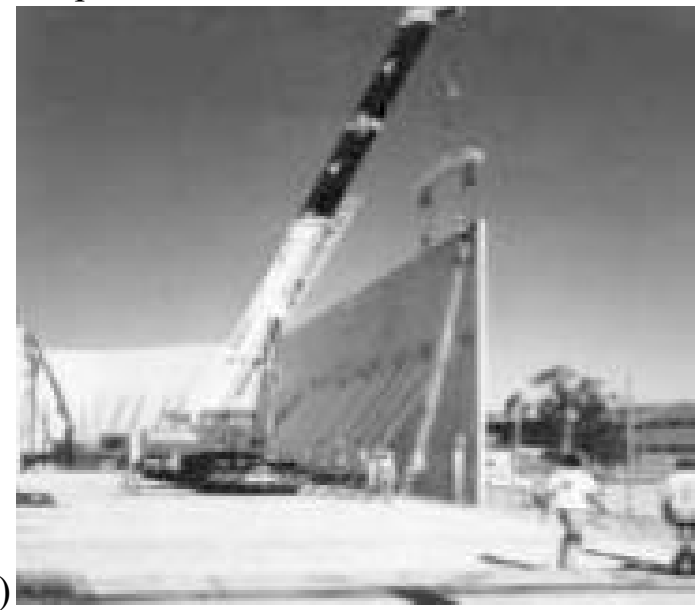

b) (a) Içamento do painel de concreto e (b) Instalação do painel com escoras provisórias. Fonte: Manual de construção em aço, (IBS/CBCA, 2004).

Camillo (2010) descreve em seu trabalho uma placa produzida com partículas de madeira aglutinadas com cimento conhecida como placa de madeira mineralizada (PCMM). A produção iniciou-se na Alemanha em 1880 e eram fabricadas com madeira, gesso e água. Atualmente são produzidas em vários continentes como o Africano, Asiático, Europeu e Americano. No Brasil as placas eram produzidas em Porto Alegre, no estado do Rio Grande do Sul pela empresa Movimax-Epex e atualmente também pela empresa Garge localizada em Blumenau, no estado de Santa Catarina (Figura 4).

Figura 4 - Centro de produção de sistema de vedação industrializado produzindo placas de madeira mineralizada

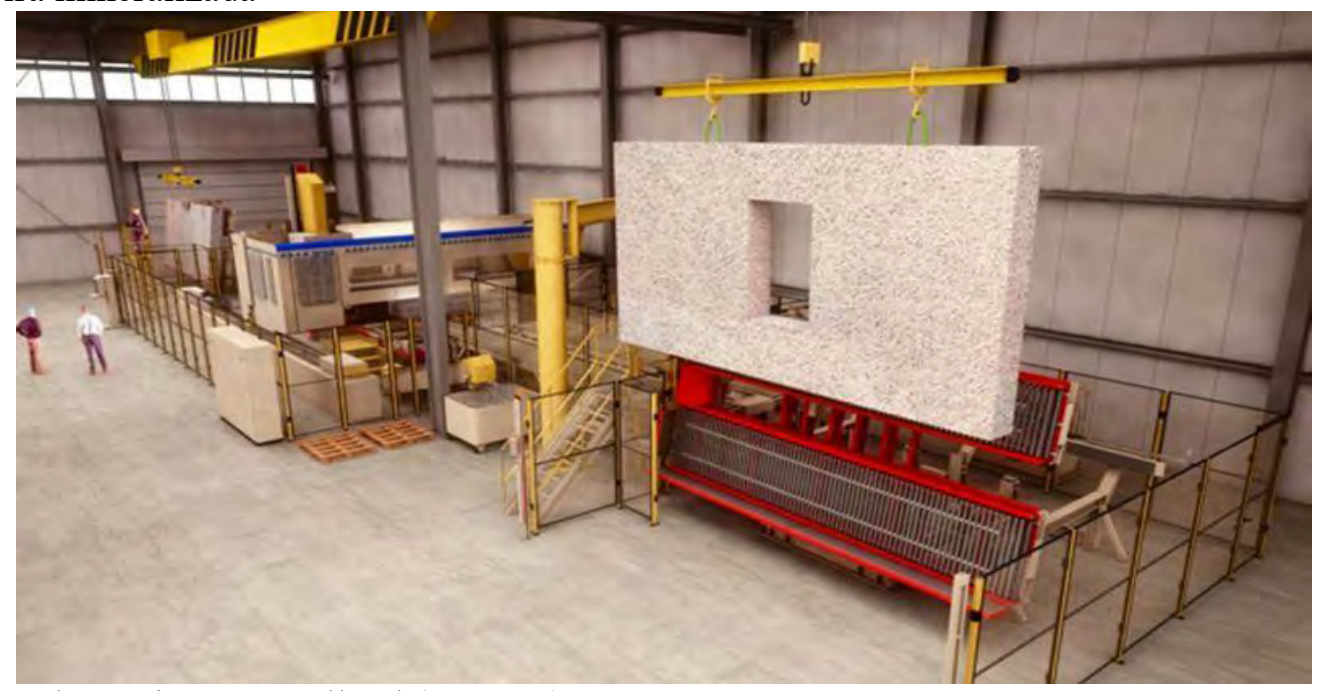

Fonte: Eltomation BV Holland (WWCB). 
O manual da construção industrializada expõe outro tipo de vedação vertical conhecida como painéis portantes, utilizados em conjuntos habitacionais, com espessura média de 10 centímetros, são produzidos em concreto ou argamassa armada, servem como isolamento interno ou externo. Similar aos painéis portantes, o sistema formado por painéis pré-moldados compostos por bloco cerâmico e concreto armado possuem nervuras de reforço, as instalações elétricas e hidráulicas acompanham o processo produtivo e ficam embutidas na concretagem do painel (Figura 5) (ABDI, 2015).

Figura 5 - Sistema pré-moldado de vedação vertical em blocos cerâmicos

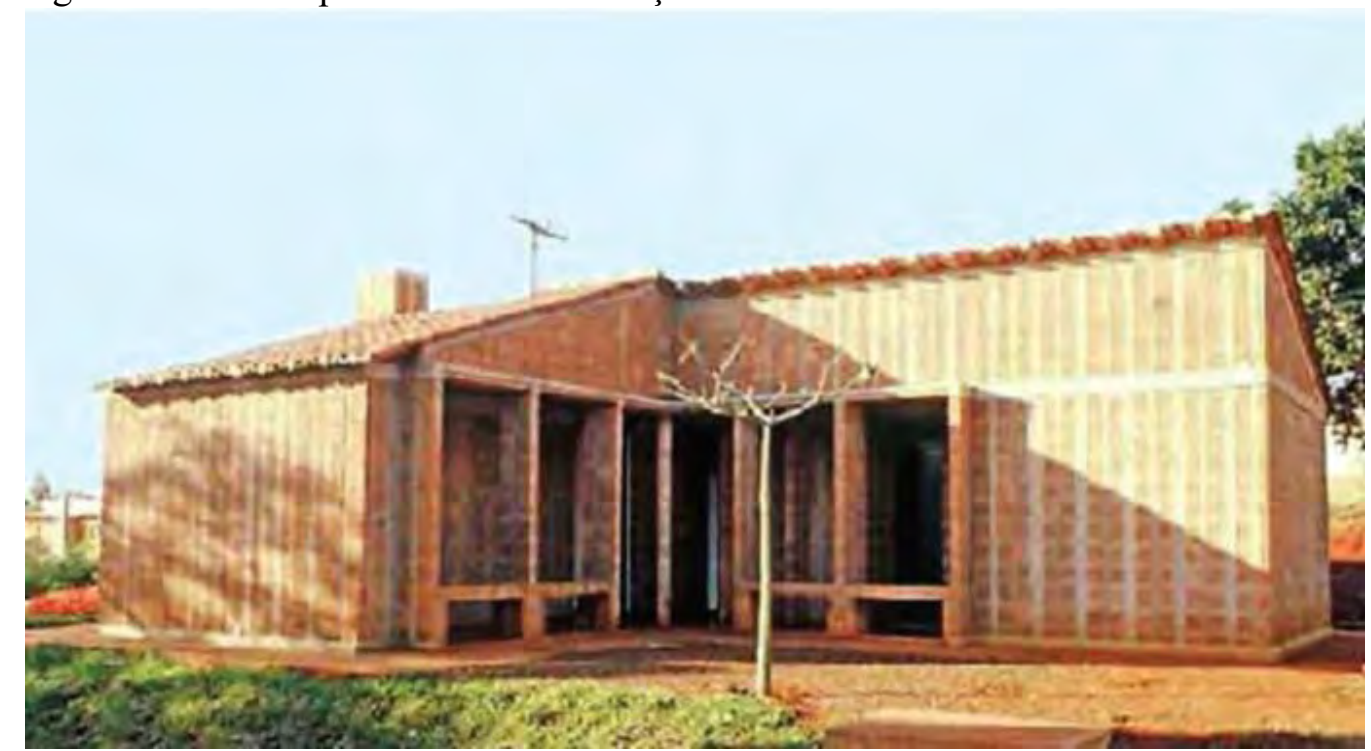

Fonte: Manual da construção industrializada, (ABDI, 2015).

Silva e Silva (2004) apresentam outra opção de painel, os painéis de fibrocimento reforçados com fibra de vidro (GRC - Glassfibre Reinforced Cement). Segundo os autores um componente leve, de elevado desempenho mecânico e conforto ambiental, conciliam flexibilidade de aplicação, mas são comumente em fachadas por permitirem a reprodução fiel do projeto em cor e textura, podem ser utilizados também em restaurações de edifícios históricos (INSTITUTO BRASILEIRO DE SIDERURGIA - CENTRO BRASILEIRO DA CONSTRUÇÃO EM AÇO, 2014) (Figura 6a e Figura 6b). 
Figura 6 - Sistema construtivo de vedação vertical em GRC

(a)

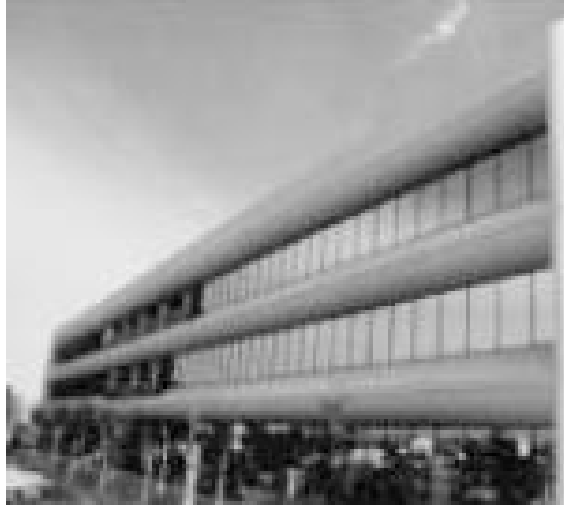

(b)

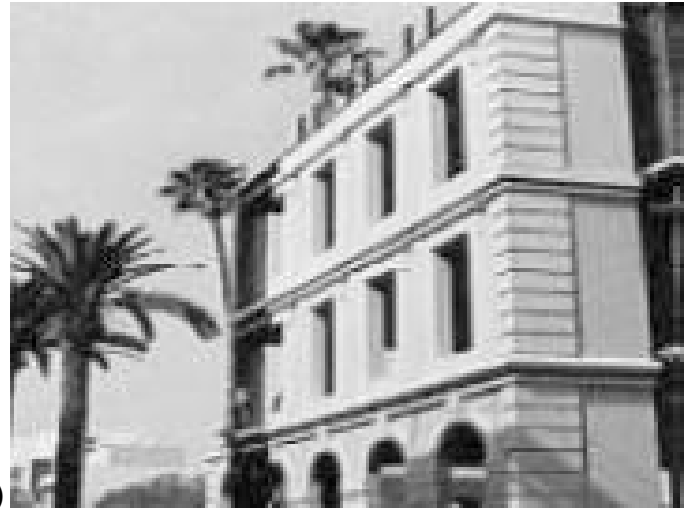

(a) e (b) Fachada com diferentes formas e dimensões nos Estados Unidos da América, estado da Califórnia.

Fonte: Manual de construção em aço (IBS/CBCA, 2004).

Outro tipo de construção industrializada é o sistema construtivo conhecido como Wood Frame, derivado dos sistemas leves em madeira adotou a tecnologia do modelo Plataforma. Seus componentes são nervurados (esqueleto de madeira) e podem formar o piso de cada pavimento, sobre estes em planos verticais são instalados as subdivisões da edificação, nos pavimentos sobressequentes são construídos com a mesma técnica e disposição. A partir da década de 1960, avançou para o sistema Panelizado, onde os painéis podem ser produzidos industrialmente fora do canteiro de obra e depois instalados sobre os pavimentos, este método contribuiu posteriormente com os outros tipos de sistemas de casas industrializadas (AGÊNCIA BRASILEIRA DE DESENVOLVIMENTO INDUSTRIAL, 2015).

De acordo com Laroca (2002) o modelo Plataforma é considerado um sistema leve de construção, porém com as paredes e o piso dimensionados para terem função estrutural. $\mathrm{O}$ autor expõe que $70 \%$ das construções residenciais nos Estados Unidos da America e no Canadá utilizam este sistema como pode ser visto na (Figura 7). 
Figura 7 - Sistema construtivo estrutural em madeira tipo plataforma - Wood Frame

(a)

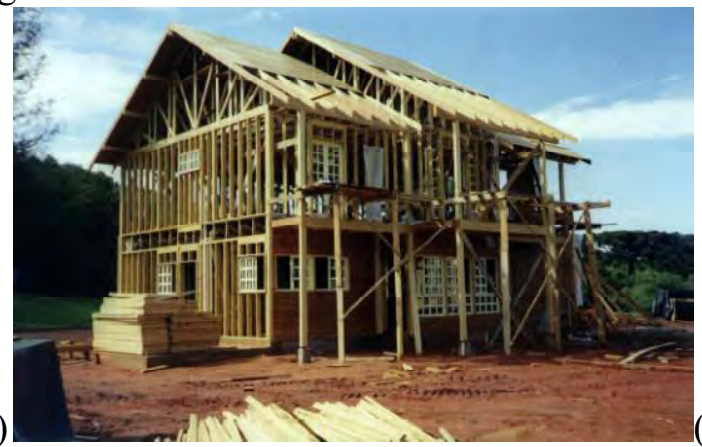

(a) Ossatura estrutural do sistema plataforma (b) Fonte: Laroca, (2002).

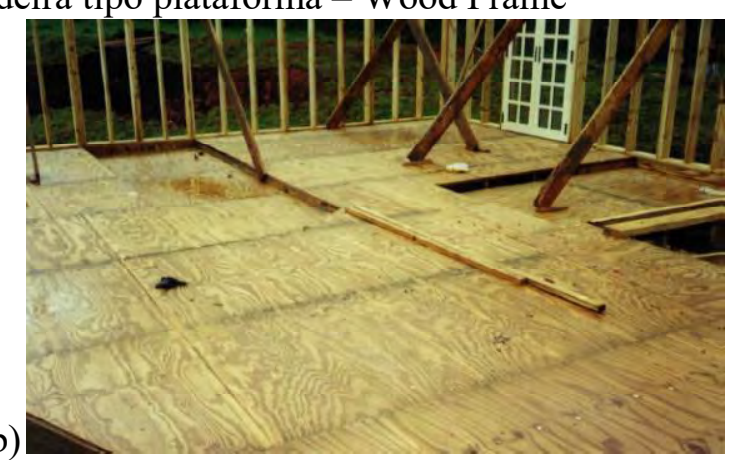

(b) Piso formado por painéis

Atualmente no Brasil, depois de alguns anos de avaliação, acompanhamento e aprovação do SINAT, em 2013 foi homologado pelo Ministério das Cidades um sistema de vedação em Wood Frame conforme (Figura 8a e 8b). Nas figuras é possível observar o uso da madeira maciça como sistema estrutural e do OSB (Oriented Strand Board) como vedação, placa de derivados de partículas de madeira, como componente formador das faces da vedação vertical, (ABDI, 2015).

Figura 8 - Sistema Wood Frame com painéis de partículas OSB

(a)
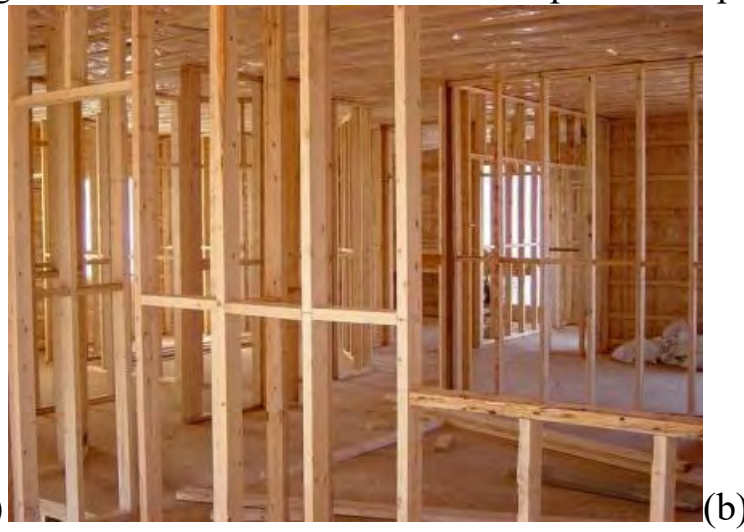

(a) Estrutura Wood Frame para painéis OSB (esqueleto de madeira) Wood Frame

Fonte: (a) site pensamentoverde, 2017; (b) site catalogodearquitetura, 2017.

O Wood Frame é considerado um sistema de vedação industrializado a seco que pode proporcionar a redução dos resíduos de obra em 90\%, tem bom desempenho térmico e ressalta-se que o processo de produção apesar de consumir recursos naturais pode diminuir o 
impacto ambiental, inclusive no canteiro de obra, com possível reuso de material empregado (AGÊNCIA BRASILEIRA DE DESENVOLVIMENTO INDUSTRIAL, 2015).

Outra versão disponível no mercado onde os painéis de OSB são utilizados é o sistema de vedação composto por estruturas em aço (esqueleto em aço dobrado a frio), onde os painéis são instalados de maneira similar ao sistema Steel Frame com placas de fibrocimento (Figura 9).

As escolhas dos novos métodos construtivos de vedação vertical interna ou externa estão relacionadas com a disponibilidade de matéria prima e ao domínio tecnológico empregado no processo. Nos países com maior domínio tecnológico é possível observar a utilização dos sistemas industrializados constituídos por painéis de dimensões moduladas e normalmente instalados em elementos estruturais leves (CAMILLO, 2010).

Figura 9 - Sistema Steel Frame com painéis de partículas OSB

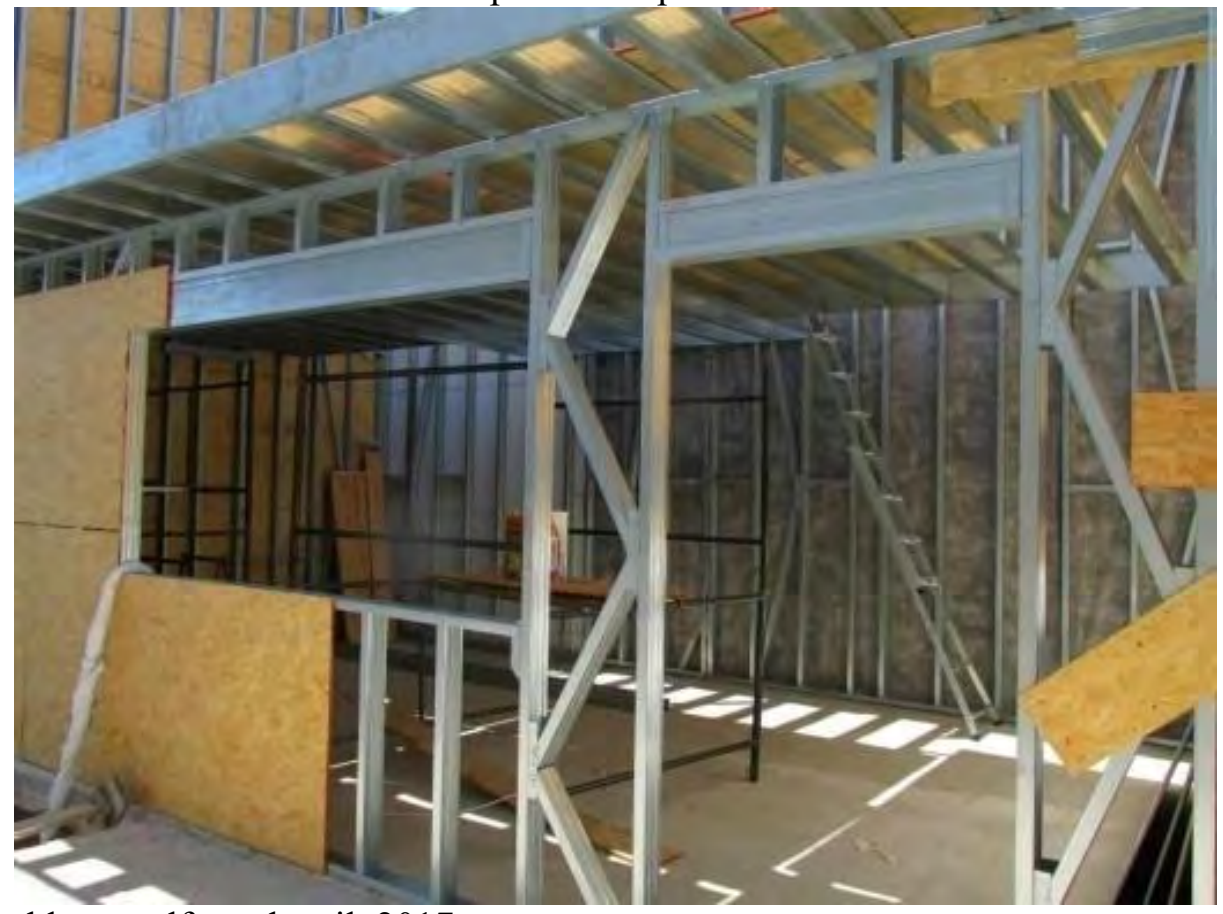

Fonte: blog steelframebrasil, 2017.

Diante do exposto, o caminho que os sistemas construtivos de vedações verticais devem percorrer, mesmo que num processo evolutivo iniciado pela racionalização como prérequisito para se atingir a industrialização, ainda está andamento, mas que para muitos pesquisadores é uma evolução inevitável. É evidentemente que os componentes e elementos têm muito a evoluir, que as empresas muito que desenvolver, fatores que demonstram 
oportunidades de crescimento de novas pesquisas sobre o tema. Portanto as próximas seções expõem o estudo de novos materiais com potencial de aplicação como componente ou elemento em sistema de vedação vertical ou em outros setores da construção civil.

\subsection{Painéis de partículas aglomerados}

Historicamente a racionalização e a industrialização dos sistemas construtivos estão associadas à coordenação modular dos componentes e elementos construtivos e um desses são os sistemas de vedação vertical com o uso de painéis. A padronização dimensional pode assegurar a intercambialidade entre componentes produzidos por diferentes indústrias da construção e dessa forma fortalecer o mercado para uma industrialização aberta. Além do reaproveitamento racional da madeira, o painel aglomerado de partícula pode proporcionar um sistema construtivo de montagem modulada padronizada e também auxiliar na redução de desperdícios. A industrialização para todos os envolvidos, fabricantes, projetistas e executores, pode trazer racionalização operacional e organizacional, sustentadas por repetições de processos e técnicas executivas, ainda contar com controle eficiente de custos de produção (BALDAUF, 2004).

Da mesma maneira que a modulação da alvenaria tradicional racionalizada e a padronização dimensional das esquadrias que impactaram a industrialização dos elementos da construção civil, o crescente interesse nos sistemas de vedação vertical utilizando painéis pode elevar esses componentes construtivos a patamares maiores e serem considerados definitivamente um avanço tecnológico como parte de um sistema de vedação, visto e considerado um forte concorrente de mercado entre os sistemas construtivos. Dessa forma, confirmar sua aptidão para a melhoria da produtividade, contribuir para a qualificação e redução de custos da industrialização dos sistemas construtivos de edificações (BALDAUF, 2004).

\subsubsection{Painéis de partículas aglomeradas de madeira}

A norma ABNT NBR 14810- 2013: Painéis de partículas de média densidade Parte 1: Terminologia descreve o painel de partículas de média densidade como um componente que pode ser produzidos com densidades variando entre de $551 \mathrm{~kg} / \mathrm{m}^{3}$ e $750 \mathrm{~kg} / \mathrm{m}$, o processo 
de produção do produto ocorre com a aglomeração das partículas de madeira por uma resina sintética termofixa que aglutinam as partículas e consolidam o componente sob a ação conjunta de pressão e temperatura (ASSOCIAÇÃO BRASILEIRA DE NORMAS TÉCNICAS, 2013).

A norma ANSI A208.1 - 1999 Particleboard, publicada pela Composite Panel Association (CPA), descreve o painel de partícula como um compósito que pode ser fabricado com materiais lignocelulósicos (normalmente madeira), geralmente na forma de partículas, diferentes de fibras, aglomerado por um sistema de aglutinação e que pode receber aditivos. A norma propõe estabelecer um consenso e o reconhecimento de um padrão sobre a indústria de painéis de partículas, entre aqueles que produzem e usam os produtos. Desta forma suas diretrizes propõem classificações que designam as resistências e aplicações gerais e específicas para cada tipo de painel de partículas segundo intervalos de densidades (AMERICAN NATIONAL STANDARD INSTITUTE, 1999).

Em seu guia de consumidores a CPA indica usos comerciais e residenciais para os painéis de partículas em móveis, tampo de balcões, armários de cozinhas, miolo de portas, piso de escadas, base para pisos laminados (Figura 7b), entre outros (CPA Buyers Guide 2018-2019 - COMPOSITE PANEL ASSOCIATION).

De acordo com Poleto et al. (2013) as primeiras produções de painéis de partículas ocorreram na Alemanha Ocidental durante a $2^{\mathrm{a}}$ Guerra mundial devido a escassez de madeira. Iniciou-se em 1943 com duas empresas que utilizaram resíduos de serraria, em 1944 desenvolveram-se tecnologias com a utilização das primeiras máquinas para a produção de painéis. Com o passar dos anos a tecnologia de produção chegou ao Brasil com a primeira empresa instalada em Curitiba em 1966.

Segundo Colli et al. (2010) os painéis também surgiram para amenizar as variações dimensionais da madeira maciça, bem como diminuir seu peso, aproveitar suas propriedades isolantes, térmicas e acústicas. Adicionalmente, com a diversidade atual de sua aplicação para vários fins, as taxas de produção desse produto vêm aumentando. A madeira utilizada e transformada em partículas de formas e geometrias variadas, bem como os tratamentos utilizados até a produção final do painel pode conferir uma variação ampla de propriedades, assim o produto final pode ser aplicado em funções específicas. Os painéis de partículas de madeira são popularmente reconhecidos na aplicação em móveis residenciais, principalmente em armários. Mas seu uso pode abranger uma variedade muito grande de aplicação. A 
evolução do uso de painéis de partículas de madeira vem avançando juntamente com as pesquisas sobre o uso da madeira processada para sistemas construtivos.

Segundo Brito et al. (2004) no país, em função da experiência no cultivo de espécies florestais de crescimento rápido, o Brasil apresenta plenas condições de produzir grandes quantidades de painéis para os diversos fins. Sendo a madeira uma matéria-prima renovável, de baixo custo para ser processada apresenta vantagens em relação a outros tipos de painéis com a mesma aplicação, porém produzidos com diferentes matérias-primas. Desde a década de 1966, o processo de produção de painéis de madeira tem sido praticamente o mesmo até os dias atuais, as toras são processadas por picadores especiais em partículas que, posteriormente são dispostas em multicamadas e prensadas com adesivos especais, os painéis produzidos dessa maneira são comumente chamados de aglomerado.

Bonilla Bueno (2015) descreve em seu trabalho que os painéis de madeira possuem forma plana, podem ser fabricados com partículas de madeira ou qualquer outro material lignocelulósico, misturados por meio de uma resina e adensados sob a ação de pressão e temperatura durante um tempo suficiente para que a cura do adesivo ocorra. $\mathrm{O}$ autor expõe que o painel de madeira de média densidade (MDP) é uma evolução da chapa de madeira aglomerada, com processo produtivo e produto final de melhor qualidade. As partículas mais finas são posicionadas nas faces e as maiores na região central formando um perfil de três camadas. Os fabricantes de MDP comercializam painéis com densidades que variam entre $600-700 \mathrm{~kg} / \mathrm{m}^{3}$ conforme o processo industrial, as espessuras podem variar entre 12 a 30 mm de acordo com a aplicação desejada.

O mesmo autor expõe que alguns trabalhos acadêmicos pesquisaram painéis produzidos em multicamadas com três tipos de madeira (Eucalyptus grandis, Eucalyptus urophilla e Pinus elliottii) obtendo densidade aproximada de $750 \mathrm{~kg} / \mathrm{m}^{3}$ e espessura de 15 $\mathrm{mm}$. Afirma que os painéis produzidos com resina de mamona apresentaram propriedades superiores aos produzidos na indústria. $\mathrm{O}$ autor também cita a produção de painéis produzidos com pinus (Pinus taeda), eucalipto (Eucalyptus saligna), bracatinga (Mimosa scabrella) e uva-do-japão (Hovenia dulcis) em diferentes proporções de misturas. Acrescenta que Nascimento et al. (2013) avaliaram painéis de partículas produzidos com espécies de madeiras do nordeste do Brasil como angico, algabora e jurema preta, os painéis produzidos apresentaram características físico-mecânicas equivalentes a painéis comerciais produzidos industrialmente. 
Uma grande quantidade de resíduo produzido pela indústria madeireira continua sendo pouco aproveitado e quando isso ocorre é para a produção de energia. Uma parcela significativa desses resíduos são cascas, entretanto as partículas de madeira apresentam boas condições de serem incorporadas no processo produtivo de painéis em substituição ou combinação com outras matérias primas. Pesquisas científicas relatam a importância de se reutilizar resíduos da indústria madeireira e resíduos urbanos como o papel e/ou sua polpa. Descreve o papel como um dos resíduos mais encontrados no mercado, pode ser aplicado em painéis de isolamento, na composição do gesso cartonado e em compósitos de fibrocimento (BRITO et al., 2004).

Assim seguindo essa tendência, pesquisas que estudam a reutilização de resíduos da agroindústria demonstram há alguns anos sua importância cada vez maior, buscam entre outras questões o desenvolvimento de materiais e produtos com o propósito de agregar valor aos subprodutos da agroindústria, por meio da incorporação ou substituição de matérias primas na produção de novos compósitos.

\subsubsection{Reaproveitamento dos subprodutos da agroindústria}

De acordo com Pereira (2012) os subprodutos da agroindústria são oriundos da indústria agrícola, têxtil, de papel, madeireira, automobilística e de processamento de metais. O autor afirma que devido a sua produção concentrada torna-se mais fácil sua reutilização; destaca que a reutilização de um subproduto demanda conhecimento das características físicas e químicas do material para evitar problemas e riscos ao meio ambiente. O pesquisador acrescenta que as fibras vegetais ganharam notoriedade em diversos estudos científicos, que focam a aplicação de materiais construtivos não convencionais como as placas de cimento e telhas reforçadas com fibras vegetais em substituição ao amianto.

Segundo Bonilla Bueno (2015) as fibras vegetais são renováveis, de baixo custo, em grande disponibilidade, menos abrasivas e muitas vezes vista como resíduo, possibilitando o reaproveitamento como uma matéria prima economicamente viável. O autor complementa o apelo ambiental que o produto apresenta, destaca que o Brasil disponibiliza uma variedade de fibras com potencial de aproveitamento como as do bagaço de cana, do pseudocaule da bananeira, polpa de celulose de eucalipto, sisal, fibra da casca de coco verde, entre outras. 
Segundo Pereira (2012) a fibra da casca de coco verde começou a ser utilizada na indústria da construção civil para a produção de compósitos com matrizes poliméricas e cimentícias com o propósito de reforço dos materiais desenvolvidos. Com baixa densidade, e boas características de resistência e durabilidade apresentam potencial para a produção de painéis pré-moldados e placas de fibrocimento.

Passos (2005) aponta a crescente possibilidade do aproveitamento de resíduos da agroindústria, tanto por questões socioeconômicas como ambientais. Diante deste fato, uma grande retomada no estudo do desenvolvimento de novos materiais com a utilização de subprodutos da agroindústria demonstra seu potencial. $\mathrm{O}$ autor destaca pesquisas recentes de aproveitamento de fibras vegetais, particularmente a fibra da casca de coco verde. Expõe que são parte do montante de resíduos gerados no meio urbano e que têm participação nas emissões de gases de efeito estufa.

Conforme Pereira (2012) outro impacto gerado é o visual, pois o descarte inadequado da casca de coco verde por ambulantes na região litorânea cria condições adversas sociais, ambientais e econômicas. Além de degradarem a paisagem e produzirem mau cheiro atraem animais peçonhentos procurando fonte de alimento, assim colocando em risco a saúde pública. Dessa forma o reaproveitamento dos resíduos pode evitar a disposição final incorreta ou ainda evitar a sobrecarga nos aterros sanitários.

\subsubsection{Fibra da casca de coco verde}

A fibra da casca de coco verde é produzida da desfibrilação do mesocarpo (Figura 10), casca externa do coco verde onde se obtém a fibra do tipo celulósica com alto teor de lignina. A fibra da casca de coco verde se enquadra na família de fibras duras como a do sisal, composta por celulose e lenho proporciona elevados índices de rigidez, dureza, resistência e durabilidade (BONILLA BUENO, 2015). 
Figura 10 - Constituição do fruto do coqueiro anão verde

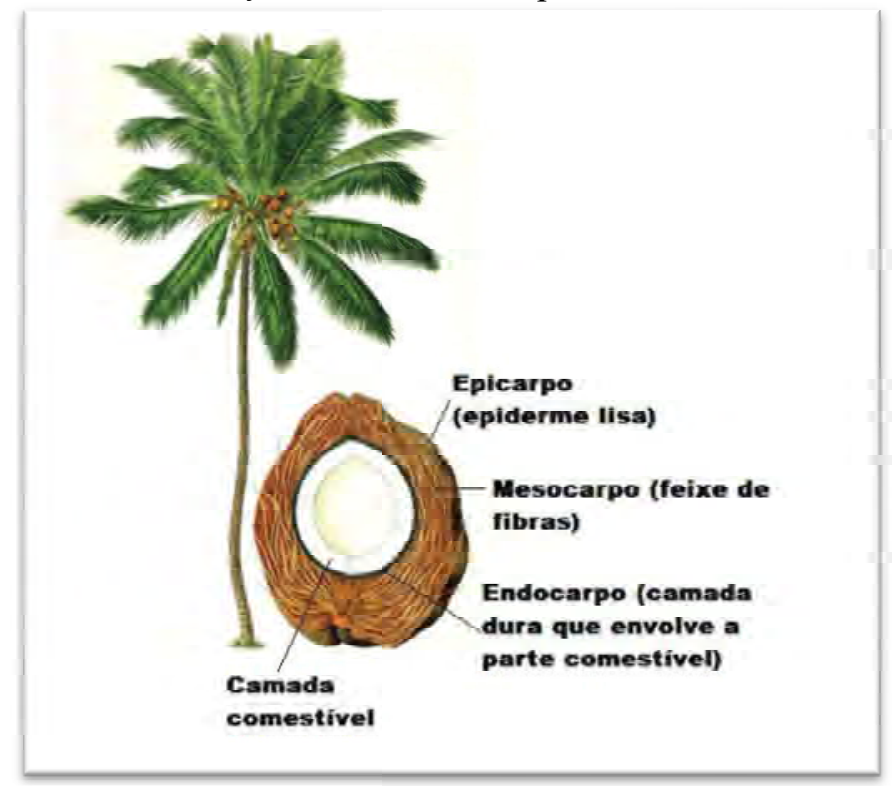

Fonte: Adaptado de Benassi, (2006).

Pereira (2012) relata que o coqueiro por ser uma planta de origem asiática, que se adapta muito bem em clima tropical, encontrou condições propícias para se desenvolver no Brasil em varias regiões como o Norte, Nordeste e recentemente no Sudeste.

Segundo o Instituto Brasileiro de Geografia e Estatística (IBGE) a área destinada à colheita de coco verde no sudeste no ano de 2015 foi de 18.720 hectares, sendo 1845 no estado de São Paulo e a quantidade de frutos produzida foi de 23.439 toneladas por mês (INSTITUTO BRASILEIRO DE GEOGRAFIA E ESTATÍSTICA, 2018).

A Empresa Brasileira de Pesquisa Agropecuária (Embrapa) aponta que em 2012 se encontravam em funcionamento apenas 12 unidades em todo o país processando 10 toneladas de cascas de coco verde por dia, expondo que o restante era depositado como resíduo. A empresa descreve que o volume processado é direcionado à produção de substrato agrícola para plantio e fibras para a confecção de vasos e xaxins. Destaca ainda a iniciativa de estudos direcionados ao reaproveitamento das fibras para a produção de painéis de partículas (EMPRESA BRASILEIRA DE PESQUISA AGROPECUÁRIA, 2018).

No item a seguir destacam-se algumas pesquisas que abordam as propriedades e possibilidades de aplicação das fibras da casca de coco verde na produção dos painéis de partículas aglomerados em substituição parcial ou total à madeira. 


\subsubsection{Painéis aglomerados de partículas de subprodutos agroindustriais}

A composição química de alguns materiais lignocelulósicos se assemelha ao da madeira de alta densidade que possui menor teor de lignina e maior teor de hemiceluloses do tipo pentosanas (COLLI et al., 2010). Os autores expõem que os painéis particulados podem ser produzidos por qualquer material lignocelulósico, porém a madeira ainda é a matéria prima mais usada. Portanto qualquer outro material lignocelulósico que conferir resistência mecânica e peso específico pré-estabelecido, similares ou maiores que as das madeiras normalmente utilizadas podem proporcionar a produção de painéis de partículas de boa qualidade. Dentre esses materiais lignocelulósicos, os autores citam inúmeras possibilidades de matérias-primas para a produção de painéis como, o bagaço de cana, a palha de cereais, o talo de algodão, bambu e fibra da casca do coco verde.

Segundo Brito et al. (2004), dos frutos do coco verde pode-se extrair fibras duras e elásticas, resistentes à ação da água podem ser aplicadas na industria têxtil, situação que já ocorre em alguns países asiáticos. Pouco utilizada no Brasil, a fibra de coco verde é um resíduo muito abundante, sua palmeira é de fácil manutenção capaz de gerar um sistema autossustentável de exploração e de acordo com o autor seu fruto pode ser utilizando por completo.

Fiorelli et al. (2015), relata que em 1990 o Brasil ocupava a décima posição no ranking mundial de cultivo de coco verde, produzindo em torno de 477 mil toneladas. Os dados do ano de 2001, com uma produção de 2,8 milhões de toneladas colocam o país como o quarto maior produtor do mundo.

No Brasil segundo Colli et al. (2010), o aproveitamento do fruto do coco ainda é tímido, as cascas são comumente levadas aos aterros sanitários com potencial de emissão de metano como toda matéria orgânica. Infelizmente ainda tratado como resíduo, o material pode produzir fibras com características particulares e potenciais para a produção de compósitos. As fibras vegetais possuem baixa massa específica e boa resistência, e segundo os autores possuem potencialidade como material alternativo de reforço em compósitos como demonstrado em muitas pesquisas. Afirmam que uma maneira de reaproveitar os resíduos da agroindústria é direcionar estudos para o desenvolvimento e produção de painéis de partículas lignocelulósicas semelhantes aos de madeira. 
Passos (2005) expõe que a fibra de coco verde tem grande quantidade de lignina, baixa densidade e grande percentual de alongamento. Em relação a resistência a tração e o módulo de elasticidade o autor relata que a fibra apresenta valores baixos, porém sua aplicação na produção de compósitos tende a diminuir a densidade do composto com boa capacidade de reforço e aumentando a possibilidade de melhorar a interação matriz-fibra, devido a ação aglutinante da lignina. $\mathrm{O}$ autor acrescenta que a ação do calor no processo de produção dos compósitos tende a aumentar a interação matriz-fibra.

Painéis de fibra da casca de coco verde apresentaram baixa condutividade térmica e resistência inferior às encontradas em painéis de madeira, entretanto foram indicadas para o uso como elementos isolantes térmicos em paredes e tetos, (KHEDARI et al., 2003).

Colli et al. (2010) fabricaram e avaliaram painéis com partículas de madeira de Paricá (Schyzolobium amazonicum Huber ex. Ducke) e fibras da casca de coco verde (Cocus nucifera L.), expõem que os valores médios das propriedades mecânicas foram afetadas pela adição de fibras de coco verde, de modo geral ocasionou aumento no módulo de ruptura, obtendo os painéis mais resistentes com o tratamento contendo 20 ou $30 \%$ de fibras. O módulo de elasticidade não foi afetado pela composição das partículas, concluíram que a madeira paricá com adição da fibra da casca de coco verde é apropriada para a confecção de painéis aglomerados.

Brito et al. (2004) produziram painéis com fibras de coco (Cocus nucifera L.) e partículas convencionais de Pinus elliottii, o menor valor absoluto de inchamento em espessura 2 horas e 24 horas foi obtido pelo tratamento com $80 \%$ de partículas de Pinus elliottii e $20 \%$ de fibra da casca de Coco nucifera L. com $8 \%$ de resina, com $14 \%$ de inchamento para 2 horas e $17 \%$ em 24 horas. Conclui-se que o aumento da porcentagem de fibra de coco na composição do painel contribuiu para a redução do inchamento, embora não ocorreu a mesma tendência para a absorção em água. Para o módulo de ruptura os painéis mostraram-se viáveis quando comparados aos valores da norma CS-236-66, para o módulo de elasticidade os resultados foram inferiores aos valores mínimos citados pela norma, segundo os autores isso indica a necessidade de trabalhos complementares.

Cravo (2013) avaliou painéis de partículas de baixa densidade produzidos com casca de amendoim e fibra da casca de coco verde adensados com resina poliuretana à base de óleo de mamona para aplicação em forros de aviários. O autor entre outras caracterizações determinou o ganho de calor solar do painel, o qual demonstrou que o compósito quando 
aplicado como forro reduz a transferência de radiação solar para o interior do ambiente, comprovando o potencial do material. O pesquisador acrescenta que a condutividade térmica do material ultrapassa valores de materiais isolantes inorgânicos e orgânicos.

Fiorelli et al. (2015) testaram painéis de partículas produzidos com maravalha de Pinus $s p$ e fibras da casca de coco verde com densidades médias de $0,80 \mathrm{~g} / \mathrm{cm}^{3}$. Os painéis fabricados com $25 \%$ de fibra de casca de coco verde, $75 \%$ de maravalha de Pinus sp e $10 \%$ de resina PU-mamona apresentaram os melhores resultados para MOR e MOE e indicam potencial para aplicações na indústria moveleira e afins.

Passos (2005) propôs a substituição da madeira na proporção de $10 \%$ a $30 \%$ de fibras da casca de coco verde, Cocos nucifera, e 90\% a 70\% de partículas de madeira Pinus elliottii para a produção de painéis aglomerados com densidade nominal média de $0,70 \mathrm{~g} / \mathrm{cm}^{3}$.

Bonilla Bueno (2015) produziu painéis multicamadas de baixa e média densidade (529 kg/m³ e $692 \mathrm{~kg} / \mathrm{m}^{3}$ respectivamente) com partículas de cana-de-açúcar e fibras da casca de coco verde com o propósito de agregar valor aos subprodutos da agroindústria. O autor conclui que as características físicas, mecânicas e térmicas dos painéis de baixa densidade são adequadas para aplicações como materiais isolantes térmicos. O pesquisador afirmou que os painéis de média densidade podem ser utilizados de forma não estrutural em ambientes internos.

Pesquisas acadêmicas apresentaram resultados que indicam a viabilidade da aplicação de materiais lignocelulósicos para a produção de painéis aglomerados, alguns exemplos como o de (CRAVO, 2013) que fabricou painéis de baixa densidade com partículas da casca de amendoim e fibra da casca de coco verde concluiu que o painel poderia ser aplicado em instalações aviárias como forro; (BONILLA BUENO, 2015) produziu painéis aglomerados multicamadas de fibra da casca de como verde e bagaço de cana e concluiu que o painel de baixa densidade pode ser aplicado como material isolante e em condições internas não estruturais e (PASSOS, 2005) concluiu que os compósitos produzidos com fibras da casca de coco verde podem ser aperfeiçoados e aplicados como isolantes acústicos, devido sua beleza rústica serem utilizados como acabamentos e forrações onde não sejam utilizados estruturalmente.

A revisão permite afirmar que os estudos de reutilização de subprodutos da agroindústria traçam um caminho sólido o qual demonstra o grande potencial de reutilização, desenvolvimento, produção e aplicação de novos materiais. Entretanto muitas pesquisas 
foram feitas e estão em andamento para o conhecimento do processo de produção e caracterização destes painéis compósitos como exemplificado no item a seguir.

\subsubsection{Parâmetros de produção dos painéis de partículas}

Fiorelli (2013) expõe em seu estudo bibliográfico que no processo de produção dos painéis de partículas existem variáveis que podem afetar as propriedades microestruturais do material a ser agregado e consequentemente as propriedades físico-mecânicas do produto final, por isso o controle destes fatores se faz de grande importância para a estabilidade dimensional e resistência mecânica dos painéis. Entre as variáveis está a geometria das partículas (tamanho e tipo) que pode influenciar as propriedades do painel com as seguintes correlações: (i) índice de esbeltez (relação entre o comprimento e a espessura das partículas), exerce influencia sobre a área de contato entre as partículas, o consumo de resina, a qualidade de acabamento e a usinabilidade do painel; (ii) razão de planicidade tem relação com o volume relativo de material dimensionado para o colchão de produção do painel e a (iii) área superficial específica também influência o consumo de resina.

Bonilla Bueno (2015) expõe que as camadas externas podem ser produzidas com partículas mais finas confeccionando painéis com um bom acabamento e aspecto visual liso e melhor usinabilidade. Por outro lado o centro produzido com partículas mais longas compondo um painel de multicamadas não prejudica as propriedades físico-mecânicas.

Fiorelli (2013) acrescenta que o bom acabamento da superfície proporciona características ideais para a confecção de móveis facilitando a aplicação de revestimento ou pintura. Entretanto os painéis produzidos com maior quantidade de partículas finas apresentam menores valores de ligação interna, prejudicam a ligação entre a camada interna e externa.

A densidade (razão entre massa e volume do painel) influência as propriedades físico-mecânicas, painéis com maior densidade possuem melhores propriedades mecânicas, porém perdem na estabilidade dimensional. Distintamente, os painéis produzidos com menores densidades apresentam redução do inchamento em espessura, melhoram as propriedades dimensionais, de isolamento térmico e acústico (FIORELLI, 2013).

Bonilla Bueno (2015) descreve a razão de compactação como a relação entre a densidade aparente do painel e a densidade aparente da espécie da madeira que originou as 
partículas para a produção do painel, o autor cita estudos desenvolvidos que indicam uma faixa aceitável dessa relação entre os valores 1,3 a 1,6 Kg/m³ $\left(1300\right.$ a $\left.1600 \mathrm{Kg} / \mathrm{m}^{3}\right)$, faixa que proporciona a ocorrência de um contato maior entre as partículas pela ligação adesiva.

Estes valores classificam o grau de densificação do produto final e apresenta relação com as propriedades físico-mecânicas do painel. A razão de compactação deve ser adequada, se a relação for muito alta em partículas de espécies de baixa densidade pode ocorrer aumento de inchamento em espessura e alteração da estabilidade dimensional, se for muito baixa, prejudica a aderência das partículas e consequentemente a resistência do painel, alterando a absorção de água por causa de maiores quantidades de vazios entre as partículas (FIORELLI, 2013).

O teor de umidade das partículas utilizadas para a produção de painéis varia entre $3 \%$ e $6 \%$. O excesso de umidade pode gerar vapor de água no colchão de partículas durante a prensagem a quente, o processo ocorre partir da face mais próxima ao prato de aquecimento para o interior do colchão e do centro para as bordas. Umidade em excesso requer maior tempo de prensagem devido à influência causada sobre a cura do adesivo. Porém, a baixa umidade do colchão reduz a transferência de calor da superfície para o centro do colchão, requerendo uma força maior de prensagem para evitar ligações de baixo desempenho entre as partículas (BONILLA BUENO, 2015).

Desconsiderando o tipo de resina, a quantidade ideal proporciona um incremento nas propriedades mecânicas e estabilidade dimensional dos painéis, por outro lado teores elevados podem gerar resíduos de material ligante, comprometendo a resistência do produto. Segundo o autor esse fato ocorre devido à disponibilidade excessiva de resina por área superficial de partícula, melhorando as ligações. Porém, acima de certo nível de excesso, o aumento do teor de resina, não melhora as ligações interpartículas, somente eleva o recobrimento superficial. O autor destaca o fato de que o modo de aplicação e distribuição da resina pode atuar sobre as características mecânicas dos painéis como, a adesão interna e o módulo de ruptura. Para resinas Poliuretanas (PU) em geral, a cura do adesivo ocorre com teor de umidade das partículas variando entre 8 e 12\% (FIORELLI, 2013).

Segundo Iwakiri (1989) a prensagem é a fase mais crítica para o bom desempenho do painel, as variáveis controláveis na prensagem dos painéis de partículas são: (i) tempo de fechamento da prensa; (ii) tempo de prensagem; (iii) temperatura e (iv) pressão de prensagem. 


\section{i) Tempo de fechamento}

O tempo de fechamento ocorre desde o contato inicial do prato de prensagem com a face do colchão de partículas, até o alcance da espessura final do painel e exerce grande influência sobre a formação do gradiente vertical de densidade (IWAKIRI, 1989).

\section{ii) Tempo de prensagem}

O tempo de prensagem é o tempo gasto do momento em que o colchão é comprimido á espessura final até a abertura dos pratos da prensa, parâmetro determinante para o rendimento do processo produtivo em escala industrial (IWAKIRI, 1989). O autor expõe que a prensagem depende da transferência de calor, parâmetro que define o tempo mínimo do processo, que por sua vez, varia de acordo com a espessura do painel, a temperatura de prensagem e a umidade do colchão de partículas.

O tempo de prensagem deve ser suficiente para que o excesso de água atinja a superfície do painel antes do tempo final do processo. Observando estas variáveis é possível controlar a temperatura do miolo do colchão de partículas para que atinja o nível requerido para a cura da resina, sem submeter a superfície do painel temperaturas excessivas. Painéis com cura inadequada de miolo podem resultar em delaminação após o término de prensagem, porque a pressão de vapor gerada é maior que a resistência da ligação interna do painel (IWAKIRI, 1989).

\section{iii) Temperatura de prensagem}

A densificação das partículas do painel ocorre durante o processo de produção mecânico de deformação por flexão e compressão até a espessura final do painel, durante esse período ocorre o aquecimento do material seguido de um processo químico que conduz à cura da resina por policondensação. A temperatura acelera a polimerização da resina que nada mais é a aceleração das reações físico-químicas distribuída entre as partículas (FIORELLI, 2013).

As principais funções da prensagem a quente no processo são: plasticização da madeira para diminuir a resistência à compressão, consolidação do colchão para alcançar a espessura e densidade programada e polimerização entre as partículas adjacentes. Maior temperatura de prensagem pode proporcionar melhores propriedades mecânicas, a densificação das camadas mais internas do painel resulta em maiores resistências das ligações internas e resistência à flexão estática (IWAKIRI, 1989). 
No entanto, temperaturas muito elevadas podem degradar a estrutura cristalina da cadeia celulósica da partícula, fato que reflete diretamente nas propriedades mecânicas do painel (FIORELLI, 2013).

Alguns autores utilizando madeiras do gênero Pinus sp e resina fenólica obtiveram bons resultados produzindo painéis com temperaturas entre 160 e $180^{\circ} \mathrm{C}$ (IWAKIRI, 1989).

\section{iv) Pressão}

A prensagem é a fase mais crítica para o bom desempenho do painel. Durante esse período vários fatores se interagem, estudos vêm demonstrando que pressões entre 40 a 50 $\mathrm{kgf} / \mathrm{cm}^{2}$ podem garantir a polimerização da resina e aglomeração das partículas. A principal função da pressão no processo é assegurar o contato entre as partículas, consolidando o colchão pela compressão. Durante a compressão uma pressão adicional é desnecessária até ser atingida a espessura final do painel. A influência que a pressão causa sobre as propriedades mecânicas do painel está relacionada com a velocidade de fechamento da prensa fator que afeta as propriedades de resistência, onde a flexão estática é a mais alterada (FIORELLI. 2013).

Muitos trabalhos abordam os parâmetros de produção de painéis de partículas homogêneas que proporcionaram referências para a escolha dos parâmetros do processo de produção e delineamento experimental deste estudo que mais a frente serão apresentados. A revisão bibliográfica destes parâmetros foi importante para a composição dos painéis formadores do núcleo do painel sanduíche, o qual foi proposto com aproximadamente $30 \mathrm{~mm}$ de espessura. Porém formados por dois painéis, pois de acordo com o estudo bibliográficos sobre o assunto espessuras maiores que $20 \mathrm{~mm}$ produzidas em laboratório podem apresentar problemas de composição estrutural, fato que pode ocorrer devido a limitações do processo de produção. Assim o núcleo proposto foi composto por dois painéis de partículas homogêneas de subprodutos da agroindústria com aproximadamente $15 \mathrm{~mm}$ de espessura, que posteriormente colados alcançaram espessuras médias equivalentes a núcleos formadores de painéis sanduiche produzidos e utilizados nos setores da construção civil. 


\subsection{Placas de fibrocimento}

\subsubsection{Parâmetros de avaliação comercial para a escolha da placa de fibrocimento}

Por definição toda placa que contém cimento, composta por uma mistura de fibras minerais, de celulose ou sintética, e agregados é chamada cimentícia, atualmente definida por norma como placa de fibrocimento, (FONTENELLE e AGOPYAN, 2012).

A utilização de materiais reforçados com fibra como componentes construtivos mais leves, com desempenho mecânico e conforto térmico adequado é uma nova tendência no mercado da construção civil (SILVA e SILVA, 2004). As autoras comparam as fibras como um atuante de reforço similarmente ao aço no concreto, aumentando a capacidade de absorver deformações à tração e impactos. Aleatoriamente disposta na matriz cimentícia, o reforço evita a propagação de fissuras e garante a tenacidade do compósito ampliando a capacidade de suporte da matriz após a fissuração.

A ABNT NBR 15498:2016 Placa de fibrocimento sem amianto - Requisitos e métodos de ensaio define placa de fibrocimento como um produto que pode ser composto por agregados, adições ou aditivos, com reforço de fibras, fios, filamentos ou telas, com exceção de fibras de amianto, misturados com cimento. A versatilidade de aplicação dos painéis reforçados com fibras é discutida e citada por muitos pesquisadores, mas o emprego mais nobre ocorre na construção civil na forma de painéis de vedação e revestimento (SILVA e SILVA, 2004).

As placas de fibrocimento produzidas pela maioria das empresas possuem largura de 1,2 metros e comprimento de 2,4 a 3,0 metros, com espessuras que variam de 6 a $12 \mathrm{~mm}$ e densidades entre 1,4 a $1,7 \mathrm{~g} / \mathrm{cm}^{3}$. Acabamento em um lado das faces com aspecto liso e a outra com aparência irregular, decorrente ao processo de produção a que a placa é submetida. As propriedades físico-mecânicas das placas de fibrocimento devem atender aos critérios de desempenho de resistência funcional das vedações verticais descritas na norma ABNT NBR 15.575-4 - 2013 - Edificações habitacionais - Desempenho - Parte 4: Sistemas de vedações verticais internas e externas - SVVIE (FONTENELLE e AGOPYAN, 2012).

Algumas empresas de maneira pioneira oferecem soluções inovadoras, desenvolvendo tecnologias que utilizam fibras sintéticas em substituição ao amianto. 
Produzida dessa maneira, algumas características físico-mecânicas gerais encontradas e atestadas por laboratórios renomados, são divulgadas pelos fabricantes como: (i) incombustibilidade; (ii) baixa absorção de água; (iii) inoxidável; (iv) durabilidade ("microconcreto armado de fibra e cimento); (v) flexibilidade; (vi) produção de baixo impacto ambiental; entre outras. Outras empresas se valem do conceito de eco eficiência por utilizar matérias-primas de baixo impacto como polpa de fibras vegetais associadas a fios sintéticos empregados como reforço de matrizes cimentícia, baixo consumo de energia e reutilização de água em seu processo (FONTENELLE e AGOPYAN, 2012).

\subsubsection{Parâmetros para a caracterização físico-mecânica da placa de}

\section{fibrocimento}

A caracterização da placa de fibrocimento pode ser feita por ensaios de desempenho de acordo com os requisitos mínimos de normas como a ABNT NBR 15498: 2014 Placa de fibrocimento sem amianto - Requisitos e métodos de ensaio e as recomendações da RILEM DRAFT RECOMMENDATIONS - Testing Methods for Fibre Reinforced Cement-based Composites determinam. Alguns dos requisitos gerais e específicos de caracterização apresentados em normas nacionais e internacionais são: dimensão e geometria da placa; espessura nominal; tolerância dimensional; tolerância de forma e características mecânicas e físicas (resistência à tração na flexão MOR, MOE e EE; densidade aparente; absorção de água; permeabilidade e comportamento sob a ação do fogo) (ASSOCIAÇÃO BRASILEIRA DE NORMAS TÉCNICAS, 2014).

\section{- Propriedades Mecânicas}

Conhecer as propriedades mecânicas dos materiais submetidos a esforços variados tem fundamental importância para que o elemento estrutural atinja o desempenho adequado e resistência à fratura. As propriedades mecânicas de compostos cimentícios são normalmente avaliadas por meio de ensaios de tração na flexão. Esses ensaios utilizam técnicas de carregamento de 3 ou 4 pontos, as amostras são solicitadas por esforços de tração e compressão. Os parâmetros determinados nestes ensaios são o módulo de ruptura (MOR), o módulo de elasticidade (MOE), limite de proporcionalidade (LOP) e energia específica (EE) (BALLESTEROS, 2014). 


\section{- $\quad$ Propriedades Físicas}

Segundo Ballesteros (2014) as propriedades físicas mais importantes a serem determinadas em compósitos cimentícios são as seguintes: porosidade aparente, densidade aparente e absorção de água. O autora expõe que o melhor desempenho dos materiais compósitos pode ser atingido se a absorção de água for limitada, que o resultado dessas propriedades pode auxiliar a avaliação da influência da adição de fibras, a condição estrutural, a ocorrência de degradação do composto e o desempenho estrutural do compósito.

As placas não são impermeáveis, mas devem atender os critérios de estanqueidade à água, característica que tem influência sobre a expansão e retração do material. Nas diretrizes das normas, as categorias e resistências à tração na flexão são subdivididas em cinco, de acordo com as classes A e B em que as placas se enquadram. As placas da classe A são indicadas para aplicações externas sujeitas a intempéries variadas, as da classe B são indicadas para aplicações internas, se forem utilizadas para aplicações externas devem estar protegidas por algum revestimento, no entanto algumas normas não especificam como fazer essa proteção. As amostras das placas da classe A devem ser ensaiadas na condição saturada e as da classe B na condição de equilíbrio (FONTENELLE e AGOPYAN, 2012).

\section{- Condutividade Térmica}

O desempenho térmico apresentado pelas placas de fibrocimento é incomparável ao de outros produtos de maior massa e espessura como, por exemplo, elementos cerâmicos para vedações verticais. Assim as placas de fibrocimento necessitam de outras camadas com materiais específicos para a composição de uma vedação vertical com o desempenho que atenda as exigências normativas (FONTENELLE e AGOPYAN, 2012).

A condutividade térmica é uma das propriedades auxiliares para prever o comportamento térmico de um material, pois pode determinar os níveis de temperatura de trabalho de um material homogêneo e problemas envolvendo transferência de calor. A condutividade térmica varia proporcionalmente com o conteúdo de água e densidade absoluta que o material apresenta (BALLESTEROS, 2014).

Gagliardo (2008) expõe que o painel sanduíche é um tipo especial de laminado, o qual possui faces com a função de suportar tensões normais de tração, compressão e cisalhamento, afastadas pelo núcleo podem ser constituídas por inúmeros materiais e entre estes a placa de fibrocimento reforçada com fibras sintéticas e naturais. 
Diante das características da placa de fibrocimento descritas anteriormente e de acordo com as funções das faces do painel sanduíche (GAGLIARDO, 2008), as placas de fibrocimento podem se apresentar como uma opção de material para formar o revestimento deste compósito, agregar características específicas ausentes no material utilizado como núcleo do painel, dessa forma associados podem compor uma estrutura eficiente com possibilidades variadas de aplicação.

\subsection{Painéis sanduíche}

Estruturas sanduíche utilizam um eficiente design que permite o desenvolvimento de projetos de estruturas crucialmente leves (WAY, 2015). Produzidos como um tipo de laminado especial possui um núcleo espesso recoberto por duas faces externas finas (GAGLIARDO, 2008).

\subsubsection{Breve histórico}

No passado, uma das primeiras aplicações da estrutura sanduíche registrou-se em 1919 na indústria aeronáutica dos Estados Unidos aplicadas em flutuadores de hidroaviões. $\mathrm{Na}$ Alemanha, em 1924, registrou-se a primeira patente de uma estrutura sanduíche aplicada em um planador (SANTOS, 1994).

A partir da década de 1950 as estruturas sanduíche passaram a ser usadas com sucesso em várias áreas da indústria, como por exemplo, a aeroespacial, produzindo itens como: (i) pás de rotor de helicópteros; (ii) bicos de aeronaves; (iii) faces das asas dos aviões; (iv) piso de compartimento de cargas entre outros. Na indústria militar para a construção de partes de mísseis e veículos, como: (i) aletas (quilhas) e superfícies de controle; (ii) antenas; (iii) tanques e (iv) contêineres de carga (GAGLIARDO, 2008).

O primeiro pouso lunar de um veículo tripulado em 20 de julho de 1969 continha a tecnologia de estruturas sanduíche, justamente com o intuito de se utilizar composições mais leves e resistentes para suportar os esforços do lançamento (NOGUEIRA DO Ó, 2009).

Allen em 1969 fez um estudo sobre o comportamento dos painéis sanduíche, onde aplicou a teoria simples de vigas da resistência dos materiais, discutindo a rigidez à flexão de faces finas e núcleos sem rigidez alguma. Seguiu a análise sobre faces grossas com 
significativa rigidez à flexão e núcleo fraco, considerando isoladamente os efeitos do momento fletor e força cortante (BERTINI, 1995).

Inicialmente utilizaram-se materiais como a madeira balsa para o núcleo, contraplacado com outras madeiras nas faces. O núcleo posteriormente se apresentou na forma de favos de abelha e telas de algodão impregnadas de verniz, enquanto as faces passaram a materiais mais modernos como a liga de alumínio. Em modelos recentes, ocorre a existência de núcleos feitos também de alumínio, porém, causando problemas de ligações com as faces, assim, surgem os núcleos de materiais sintéticos expandidos, com uma relação peso/resistência mais favorável que a balsa, porém não descartando a possibilidade da aplicação de núcleos maciços (SANTOS, 1994).

Segundo Almeida (2009) durante a Segunda Grande Guerra surgiram os primeiros escritos sobre painéis sanduiches, historiadores associam o nome de Fair Bairn como um dos primeiros responsáveis pelo registro deste compósito. Ainda a ideia da construção em sanduíche pode ter ocorrido de formas diferentes e por vários engenheiros. Utilizado em estruturas mais antigas e menos grandiosas, a aeronave "Mosquito" é considerada a primeira estrutura de importância a receber painéis sanduíche. Concebida durante a Segunda Grande Guerra, foi produzida com laminas de madeira folheada em multicamadas com núcleo de madeira balsa (Figura 11).

Figura 11 - Aeronave produzida em painel sanduíche

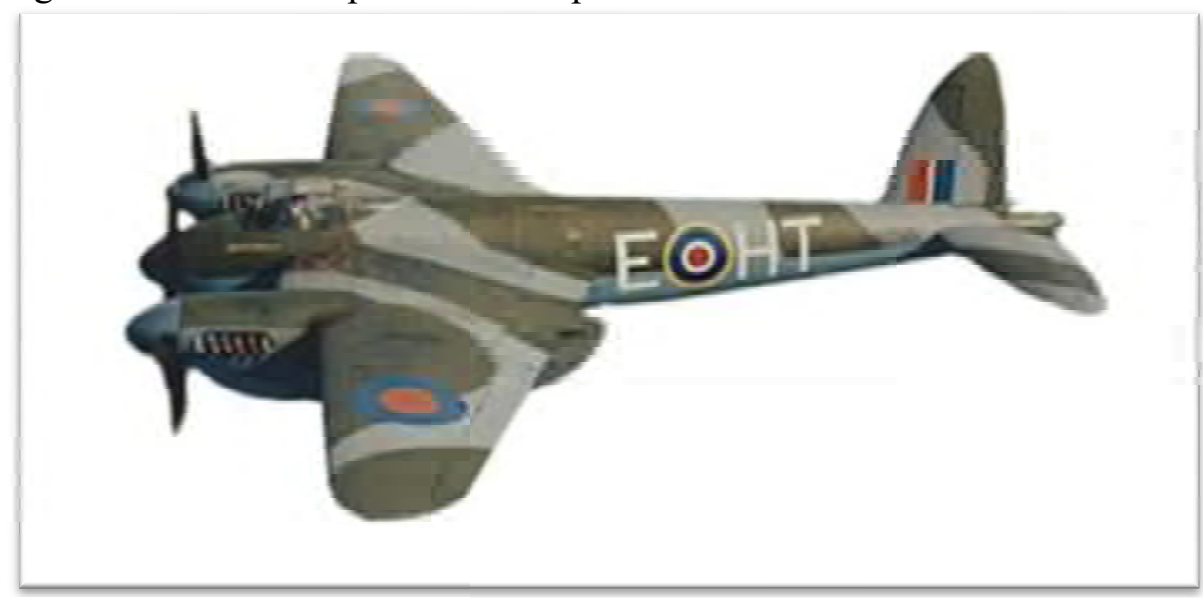

Fonte: Almeida (2009).

Segundo Bertini (1995) um sistema construtivo formado por pré-painéis chamado MONOLITE e utilizado em vários países europeus como Alemanha, Espanha, França, 
Inglaterra e Itália, foi utilizado na América Latina inicialmente na Argentina e depois trazido ao Brasil. No Brasil constituído de uma chapa de poliestireno expandido contornada por telas soldadas, ligadas entre si por fios transpassados eram revestidas por argamassa.

Outro sistema desenvolvido nos Estados Unidos no fim da década de 1970, com incentivo do governo federal, nomeado CHANG, foi preparado para a demanda de construções populares. O painel sanduíche foi utilizado como componente de paredes, piso e coberturas. As faces eram compostas por argamassa armada e o núcleo por nervuras moldadas em papelão como formas tipo caixão perdido (Figura 12).

Figura 12 - Painel sanduíche com sistema caixão perdido

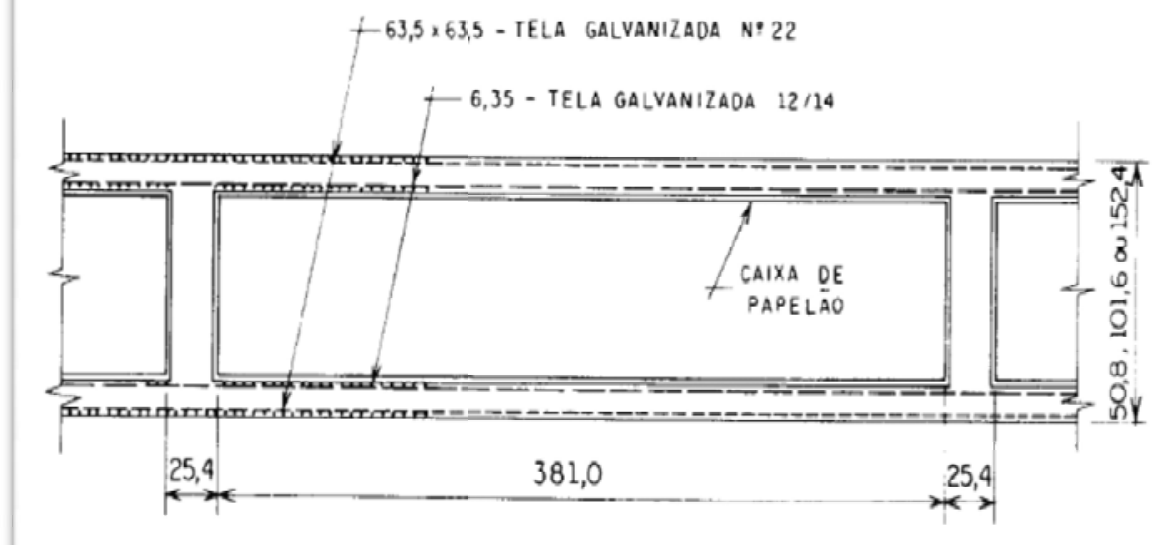

Fonte: Bertini, (1995).

As construções eram relacionadas ao encontro de demandas de materiais "fortes", não necessariamente apresentavam eficiência em ambos os casos, de utilização e custo. $\mathrm{O}$ desenvolvimento de novos produtos foi necessário para demandas associadas a grandes estruturas, minimizando custos de materiais, transporte, tempo de construção e menores impactos ao meio ambiente, principalmente ao redor do edifício (WAY, 2015).

Em todos os casos a construção de uma estrutura sanduiche pode proporcionar a economia de materiais empregados com possível melhoria de desempenho e elementos mais leves com resistência adequada. $\mathrm{O}$ fato de possuir a configuração básica de duas faces de um material resistente separadas por outro material, em geral de baixa densidade e resistência inferior às faces, mas que em conjunto apresenta resistência à flexão superior a uma placa maciça com o mesmo peso das duas placas externas que compõem as faces, talvez esta seja a causa do grande impulso de sua utilização nas mais diversas áreas (BERTINI, 1995). 
Em seu trabalho Manalo (2013) destaca painéis compósitos de fibra aplicados em obras civis de infraestrutura, apresenta este elemento construtivo como um material de nova geração desenvolvido e utilizado nas ultimas décadas. O autor escreve sua estrutura como um laminado especial, um compósito fabricado unindo duas finas faces com um espesso núcleo, porém leve. O pesquisador acrescenta que por suas características especiais pode melhorar sua rigidez na flexão, sua resistência resulta do tipo de construção a que é submetido combinando propriedades vindas das faces, do núcleo e da interface entre eles.

No próximo item abordamos os conceitos básicos das partes que compõem o painel sanduíche, as variedades de formas e materiais aplicados nesta estrutura tão interessante.

\subsubsection{Componentes construtivos e propriedades estruturais do painel sanduíche}

Entre todas as possibilidades de conceitos de design das estruturas compósitas, muitas idealizações foram e estão surgindo para os painéis sanduíche e vem crescendo popularmente por causa do desenvolvimento de materiais para núcleos conhecidos como celulares. Uma estrutura sanduíche consiste de (PETRAS, 1998): (i) um par de fina, rígida e forte "pele" (revestimentos ou faces); (ii) um espesso e leve núcleo para separar as faces e carregar cargas de uma face para outra e (iii) um adesivo capaz de transmitir cisalhamento e cargas axiais para e provenientes do núcleo (Figura 13).

Figura 13 - Painel sanduíche com núcleo celular

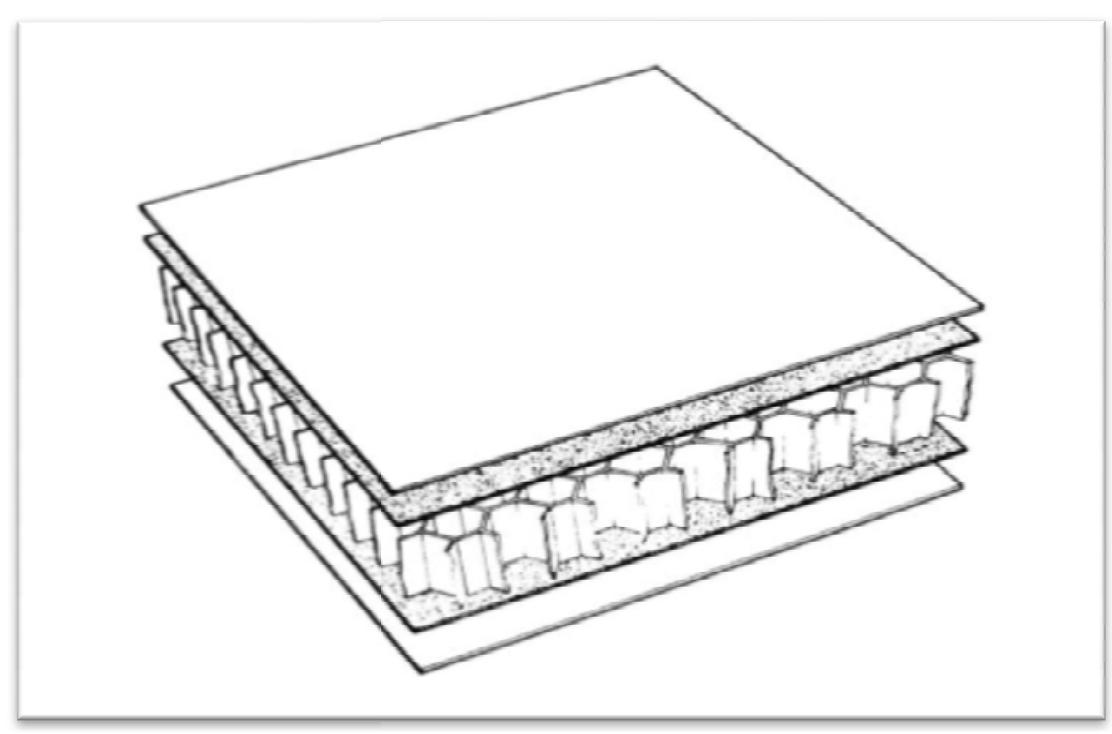

Fonte: Petras, (1998). 
Nogueira de Ó (2009) afirma que uma estrutura sanduíche é sempre constituída por duas faces e um núcleo, entretanto, o projeto de uma estrutura sanduíche não se resume a parâmetros geométricos, mas também em um processo de dimensionamento que integra seleção de materiais e uso.

Uma construção sanduíche pode ocorrer da associação de materiais simples ou compostos, combinados de várias maneiras, fixados um contra o outro. O núcleo e as faces, com funções distintas, igualmente importantes são responsáveis pelo correto funcionamento do painel sanduíche. O núcleo garante a distância ideal entre as faces e a transferência de esforços, deve possuir rigidez capaz de resistir ao cisalhamento e ao escorregamento entre eles. O núcleo, nem sempre com funções estruturais, pode melhorar o conforto térmico e associados a conectores estruturais ou nervuras garantem a composição estrutural do painel sanduíche. A resistência à flexão destes materiais possui valor baixo e desprezível ficando esta função para as faces. Alguns materiais empregados como faces são: (i) metais; (ii) madeira compensada; (iii) fibrocimento; (iv) plásticos e (v) papelão. Como material de núcleo: (i) resinas plásticas expandidas, pré-expandidas e rígidas (poliuretano e poliestireno); (ii) madeira compensada; (iii) papelão e (iv) gesso (BERTINI, 1995).

As faces são produzidas com diversos materiais incluindo ligas de alumínio, plásticos reforçados com fibras, o titânio, o aço e painéis de madeira reconstituída. O núcleo é responsável entre outras funções, ter rigidez suficiente para manter as faces afastadas uma da outra a uma distância ideal, deve também resistir ao cisalhamento e garantir que a estrutura quando fletida, as faces permaneçam aproximadamente paralelas (GAGLIARDO, 2008).

De acordo com Way (2015) os núcleos são classificados em duas categorias: “celulares" e "estruturais". Núcleos celulares têm espaços vazios fechados entre paredes que compõem as faces, como as estruturas em colmeias de abelha. Os estruturais são compostos de redes contínuas feitas de materiais sólidos, como por exemplo, o estado encontrado em painéis de fibras de madeira. Entretanto núcleo estrutural é também composto por estruturas corrugadas, onduladas e em malhas (Figura 14a e 14b). 
Figura 14 - Exemplos de núcleos para painéis sanduíche

(a)

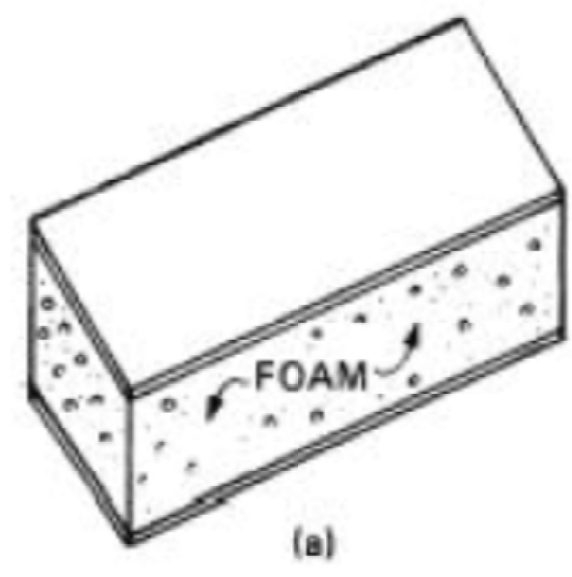

(a)

(a) espuma (b) geometria colmeia hexagonal Fonte: Way, (2015).

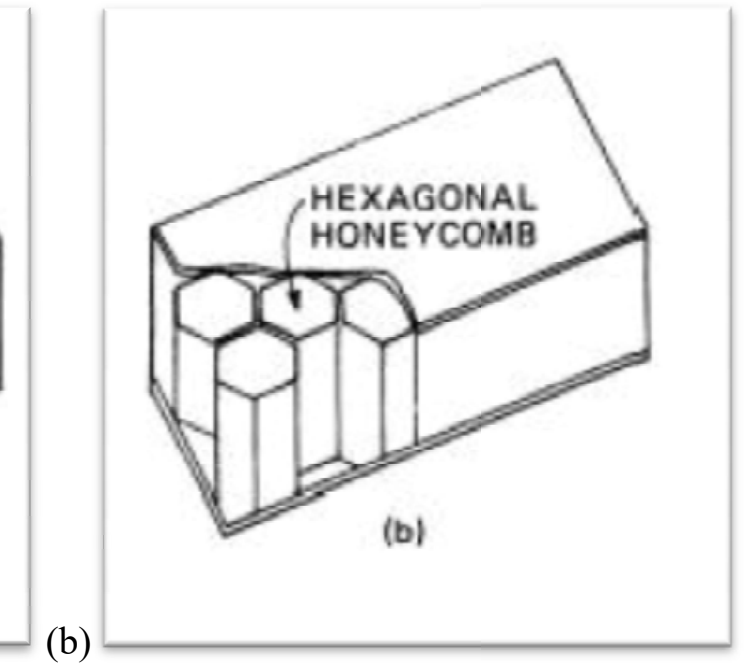

(b)

Similares aos painéis sanduíches de núcleos com a geometria de favo de mel existem os núcleos canelados, são constituídos por células abertas na direção das faces (paralelas às faces), ligadas tangencialmente as faces superior e inferior. Podem ser formados por tiras paralelas perpendiculares às faces (Figura 15a), por elementos tubulares (Figura 15b), por treliças (Figura 15c) e outra forma possível de núcleo se assemelha a estrutura da caixa de ovos (Figura 15d). Segundo o autor com estes tipos de estruturas é possível reduzir a perda de resistência ao esmagamento que ocorre em bordas não apoiadas em núcleos convencionais (ALMEIDA, 2009).

Figura 15 - Painéis sanduíche e tipos de núcleos canelados

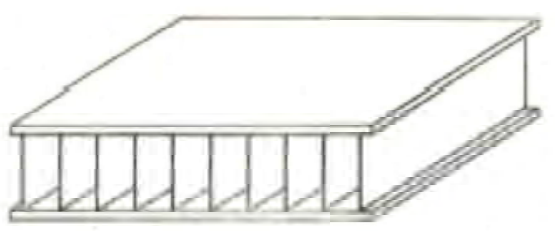

(a)

(a) canelado paralelo perpendicular (b) tubular paralelo Fonte: Almeida, (2009). 

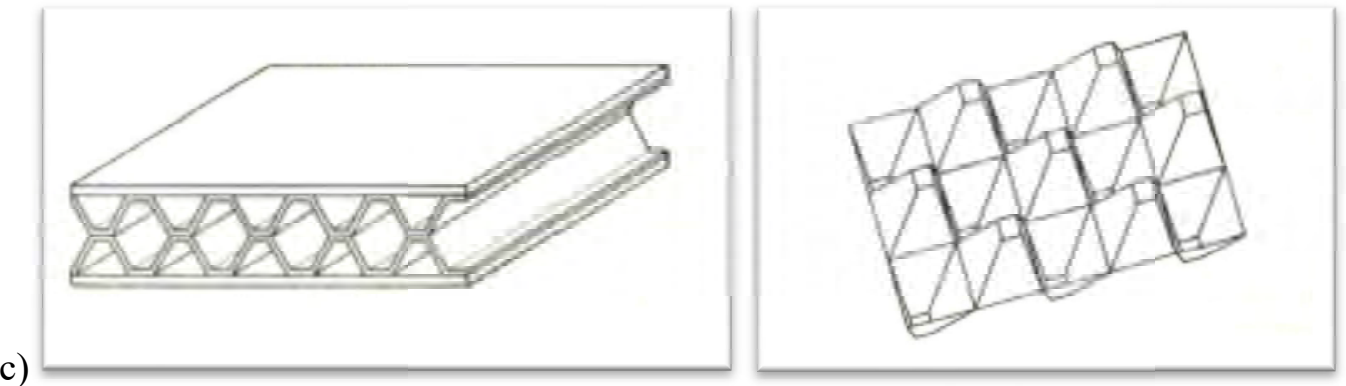

(c) treliçado paralelo (d) similar caixa de ovo

Fonte: Almeida, (2009).

Nogueira de Ó (2009) afirma que o interesse por núcleos de baixa densidade caracteriza a estrutura sanduíche. Os núcleos mais utilizados são em madeira balsa, espumas, materiais de geometria em favo de abelha e material ondulado, demonstrados esquematicamente na (Figura 14). As espumas podem ser poliméricas ou metálicas, injetadas e expandidas entre as faces ou pré-fabricadas e coladas. Os materiais de geometria em favo de abelha podem ser metálicos e não metálicos, que englobam materiais como papel Kraft ondulado, poliméricos, compósitos fibrosos ou papel adensado com resinas. O mesmo autor afirma que os núcleos de espuma proporcionam os melhores isolamentos térmicos, os materiais mais utilizados e aplicados de várias formas são o poliuretano (PUR), polisocianurato (PIR), poliestireno expandido ou extrudado (EPS/XPS), a resina fenólica (FP) e também como função isolante o policloreto de vinil (PVC). A madeira balsa foi o primeiro material a ser utilizado como núcleo para compor um componente estrutural, isto se deve ao fato da madeira ser leve com apenas $160 \mathrm{~kg} / \mathrm{m}^{3}$ aproximadamente, com estrutura celular pode ser moldado com geometria em colmeia de abelha.

Gagliardo (2008) cita alguns materiais utilizados no núcleo dos painéis sanduíches como as espumas (materiais sintéticos), borrachas sintéticas, cimentos inorgânicos, alumínio, papel, fibras de vidro e madeiras de baixa densidade. A autora descreve que as faces durante a flexão não devem deslizar sobre o núcleo, função que o adesivo precisa exercer. Expõe que os adesivos são fabricados em diversas formas, como líquidos, pasta, pós e filmes e os principais adesivos utilizados na produção de painéis de estruturas sanduíche são à base de epóxi, por serem conhecidas em aderir nas mais variadas superfícies.

Sendo a balsa (Ochrom a sp.) a madeira mais leve comercialmente disponível no mercado, é considerada um importante material para o design de núcleos de painéis sanduíche, possui considerável resistência a tensão para seu peso, por isso muito utilizada na 
aplicação de projetos de aeronaves e marinhos. O autor acrescenta que o uso do painel sanduiche compostos por madeiras na construção civil ainda é limitado. Algumas exceções são os painéis utilizados como isolantes que ganham popularidade ao longo dos anos como materiais ecológicos (green materials), possuem boas propriedades isolantes e consistem em um núcleo de espuma polimérica revestida de painéis de madeiras estruturais como faces. Polímeros reforçados com fibras e revestidos com madeira balsa ganharam notoriedade quando aplicados em pontes tipo decks, onde ofereceram resistência a corrosão marinha, redução no tempo de aplicação construtiva, durabilidade e baixa manutenção (WAY, 2015).

Santos (1994) descreve o painel sanduíche como uma estrutura mista, constituída por duas faces de um material de alta resistência, intercaladas por um núcleo mais espesso de um material mais leve e menos resistente. Acrescenta que a existência do núcleo aumenta o momento de inércia (I) da seção transversal por distanciamento das faces, estabiliza o conjunto e retarda o aparecimento de uma instabilidade local.

O princípio do comportamento estrutural do painel sanduíche pode ser comparado ao de uma viga de seção I, a função da face compara-se aos banzos e o núcleo do painel sanduíche se assemelha à alma da viga, assim, no painel sanduíche a rigidez a flexão aumenta de acordo com o distanciamento das faces, ou seja, o incremento da espessura do núcleo, como acontece na viga I com o afastamento dos banzos. Nos dois casos quanto maior for o afastamento maior é a inércia, consequentemente a rigidez à flexão, sem que o painel ganhe um aumento expressivo de peso (CRUZ, 2017).

Complementa Way (2015) expondo que os painéis sanduíche são compósitos estruturalmente análogos a uma viga I. Relativamente finas e resistentes, as faces agem como a mesa da viga I ou ainda como uma casca de reforço, enquanto que o núcleo, espesso com baixa resistência, baixa densidade e muitas vezes com estruturas semivazadas age como uma rede de estrutura ou uma membrana elástica de filamentos.

Segundo Petras (1998) a separação das faces pelo núcleo do painel sanduíche proporciona o incremento do momento de inércia com um pequeno aumento de peso, possibilitando a produção de uma estrutura eficiente para resistir flexões e pressões de carregamentos. $\mathrm{O}$ autor apresenta em seu trabalho o aumento da rigidez e da resistência à flexão do painel sanduíche contra os painéis sólidos, para isso o autor considera a espessura total do painel sanduíche igual a $(\mathrm{t})$. Usando uma teoria de dimensionamento de vigas e adotando o valor (2t) para a espessura de faces e núcleos, o autor expõe que a simples divisão 
do painel sólido em duas metades iguais formando as faces separadas por um material que compõe o núcleo, a nova estrutura majora seu momento de inércia e o resultado desse novo componente é um painel sanduíche. O novo painel minimamente mais pesado pode apresentar resistência e rigidez a tensões na flexão muito maiores que a de seu concorrente maciço, dobrando a espessura do material do núcleo, o painel configura a espessura igual a (4t) proporcionando um aumento ainda maior das suas propriedades.

Nogueira do Ó (2009) acrescenta que a espessura do painel sanduíche é muito importante, fator determinante na rigidez à flexão, a autora afirma que é possível obter valores satisfatórios desta propriedade com materiais de Módulo de Elasticidade inferiores, desde que se adapte a espessura proposta. Estas propriedades encontram-se ilustradas no (Quadro 1) onde se pode observar o incremento da rigidez com o aumento da espessura do núcleo e distanciamento das faces.

Quadro 1 - Eficiência estrutural do painel sanduíche em razão da espessura t

\begin{tabular}{|l|c|c|c|c|}
\hline \multicolumn{5}{|c|}{ Eficiência do painel sanduíche em termos de peso } \\
\hline Representação do crescimento do núcleo e espessura do painel sanduíche: \\
\hline \multicolumn{2}{|c|}{ Propriedades } & Configuração t & Configuração 2t & Configuração 4t \\
\hline Rigidez Relativa em Flexão & 1 & 7 & 37 \\
\hline Resistência Relativa à Flexão & 1 & 3.5 & \multicolumn{2}{|c|}{9} \\
\hline Peso Relativo & 1 & 1.03 & \multicolumn{2}{|c|}{1.06} \\
\hline
\end{tabular}

Fonte: Adaptado Nogueira do Ó, (2009).

Segundo Cruz (2017) a eficiência estrutural à flexão do painel sanduíche está associada aos materiais empregados na composição do painel sanduíche, a interação entre os componentes que segundo o autor é chamada de "efeito sanduíche".

Way (2015) acrescenta que na flexão, as faces são responsáveis por resistirem forças de momento enquanto o núcleo responde por forças de cisalhamento e a estabilidade das faces. As faces devem também igualmente distribuir carga e prevenir ondulações e descolamentos do núcleo. 
Análises próprias de demandas estruturais e um entendimento do comportamento mecânico das faces e núcleo facilitam os procedimentos de modelagem. As faces se comportam de maneira simples, porém, os núcleos em materiais expandidos e em forma de colmeia demandam um pouco mais de atenção (PETRAS, 1998).

Diante das importantes propriedades descritas, os próximos itens apresentam alguns exemplos práticos de aplicação de painéis sanduíches fornecidos pela indústria da construção civil internacional e nacional.

\subsubsection{Considerações sobre painéis sanduíche disponíveis na indústria da construção civil}

Gagliardo (2008) em seu trabalho descreve, a evolução das estruturas a partir da década de 1950, usadas com sucesso em algumas áreas da indústria como a espacial, militar e da construção. Especificamente, da mesma forma como aconteceu com os materiais compostos em geral em outras indústrias, a aplicação dos painéis sanduíches tem avançado em direção a industrialização da construção civil, que a partir da década de 1990 alcançou notoriedade quando surgiram as primeiras aplicações em: (i) abrigos pré-fabricados; (ii) divisórias, forros e pisos; (iii) portas; (iv) lajes e vigas; (v) coberturas e telhas e (vi) passarelas e mezaninos. A área da construção civil passou recentemente a utilizar mais elementos e/ou componentes do tipo sanduíche, no entanto já existem no mercado materiais bem desenvolvidos com características suficientes para se aplicar como elemento construtivo em sistemas variados, resistentes a intempéries, com excelente isolamento térmico e acústico, capazes de resistirem ao fogo, cargas variadas e grandes vãos.

Projetos de estruturas do tipo sanduíche visam estruturas leves e resistentes, são especialmente eficientes na resposta a esforços de flexão e compressão. O seu uso vem aumentando devido sua capacidade de combinar rigidez e baixo peso. Os autores afirmam que para cada finalidade de uso os painéis apresentam propriedades mecânicas específicas (GAGLIARDO e MASCIA, 2010).

Segundo Santos (1994) na engenharia civil técnicas convencionais são as mais utilizadas, porém sistemas alternativos começam ser aplicados para necessidades especiais. Algumas das características conhecidas das estruturas sanduíche é a relação peso/resistência,

o que pode possibilitar junto com a pré-fabricação a facilidade de aplicação, outra 
possibilidade é associar o aproveitamento do núcleo como material isolante, dessa forma pode-se credenciar este elemento como parte de um sistema construtivo em larga escala. $\mathrm{O}$ autor expõe que as aplicações mais comuns são na construção de painéis pré-fabricados para fachadas e coberturas, produzidos com faces metálicas lisas ou corrugadas com núcleos isolantes de espumas sintéticas.

Bertini (1995) expõe o uso de painéis sanduíche na construção civil composto por faces em argamassa armada e núcleo em poliestireno, descreve também o uso de faces em aço ou alumínio. O autor cita a patente da Forest Products Laboratory, obtida nos Estados Unidos na década de 1930, foi utilizada para a pré-fabricação de painéis sanduiche em madeira. Os painéis eram utilizados como paredes, forros e pisos, compostos por faces de madeira compensada colada e enrijecedores de madeira maciça formavam um componente construtivo vazado, o vazio entre eles posteriormente preenchido com material isolante completava o elemento de um sistema construtivo.

Ferreira (2012) expõe que a aplicação de painéis sanduíches é mais comum em edifícios comerciais e industriais, onde a relação peso/rigidez é importante, as cargas atuantes são reduzidas e as estruturas de vedação com exigências térmicas e acústicas. Algumas aplicações são as coberturas acabadas com revestimentos metálicos e núcleos de poliuretano (Figura 16a) e GFRP (Glass Fibre Reinforced Polymer) (Figura 16b).

Figura 16 - Painéis sanduíches aplicados como cobertura

(a)

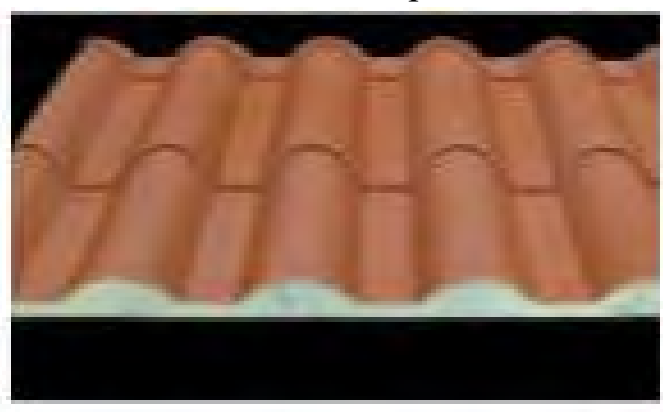

(a) Painel sanduíche ondulado metálico (b) Painel sanduíche em GFRP Fonte: Ferreira (2012).

Santos (2013) descreve a diversidade de aplicação deste tipo de estrutura, variando os materiais empregados em função da utilização, meio ambiente, condições técnicas de produção e naturalmente da viabilidade econômica para substituir materiais mais convencionais oferecidos no mercado. 
Manalo (2013) cita a empresa CarbonLOC Pty Ltda situada na Austrália como a produtora de um novo painel compósito sanduíche de fibra de baixa densidade e material de núcleo com alta resistência. Suas faces são feitas de fibra de vidro E-CR (variante do vidro E "Eletric glass") em formação biaxial (0/90) e um núcleo fenólico enrijecido com resina fenolformaldeído, o painel foi aplicado em algumas construções residenciais e vem sendo aplicada como deck de pontes e infraestrutura de autoestradas. Como plataforma de pontes é uma boa alternativa em rigidez e resistência se comparado pelo peso de outros materiais, como no caso de uma passarela produzida em aço reforçado com concreto. Algumas variáveis deste compósito constituem características descritivas do pré-moldado, como o apoio transversal ou longitudinal entre elementos de suporte, e podem ser suspensos por cabos de tensão. Nos Estados Unidos da América foi produzido um deck de ponte com núcleo de balsa (Figura 17), por ser leve, a estrutura pode ser montada em condições e locais adversos, com controle estrutural próprio e apoiado sobre uma estrutura se apresenta como um sistema diferenciado.

Figura 17 - Painel sanduíche com núcleo de madeira balsa para plataforma de ponte

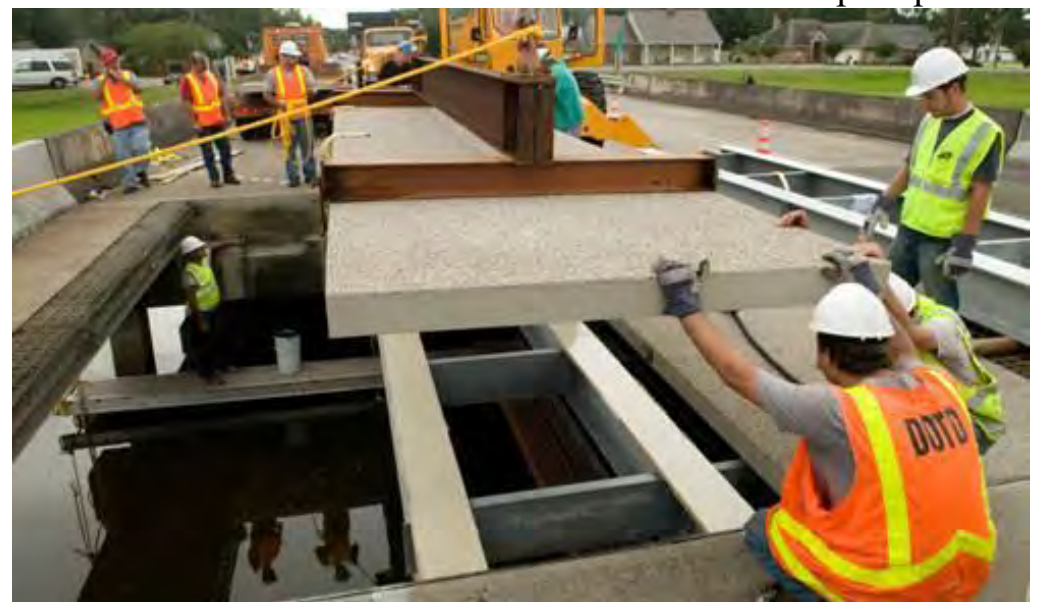

Fonte: Manalo, (2013).

Similarmente, a Ponte Bex sobre o Rio Avançon (Suiça), reconstruída em 2012, recebeu um novo tabuleiro que anteriormente construído em concreto armado, foi substituído por um painel sanduíche de $285 \mathrm{~mm}$ de espessura composto por faces de GFRP (Glass Fibre Reinforced Polymer) e núcleo de madeira balsa. A montagem do painel foi feita na margem do rio e posteriormente colocada sobre as longarinas da ponte, esta solução permitiu aumentar a capacidade de carga da ponte, a durabilidade e diminuir o tempo de interdição de uso do local. O engenheiro projetista Sébastien Lavanchy afirmou que apesar da espessura ser similar 
a uma solução tradicional o peso significantemente menor ficou próximo de $160 \mathrm{~kg} / \mathrm{m}^{3}$ (Figura 18) (CRUZ, 2017).

Figura 18 - Ponte Bex montada em painel sanduíche com núcleo de madeira balsa

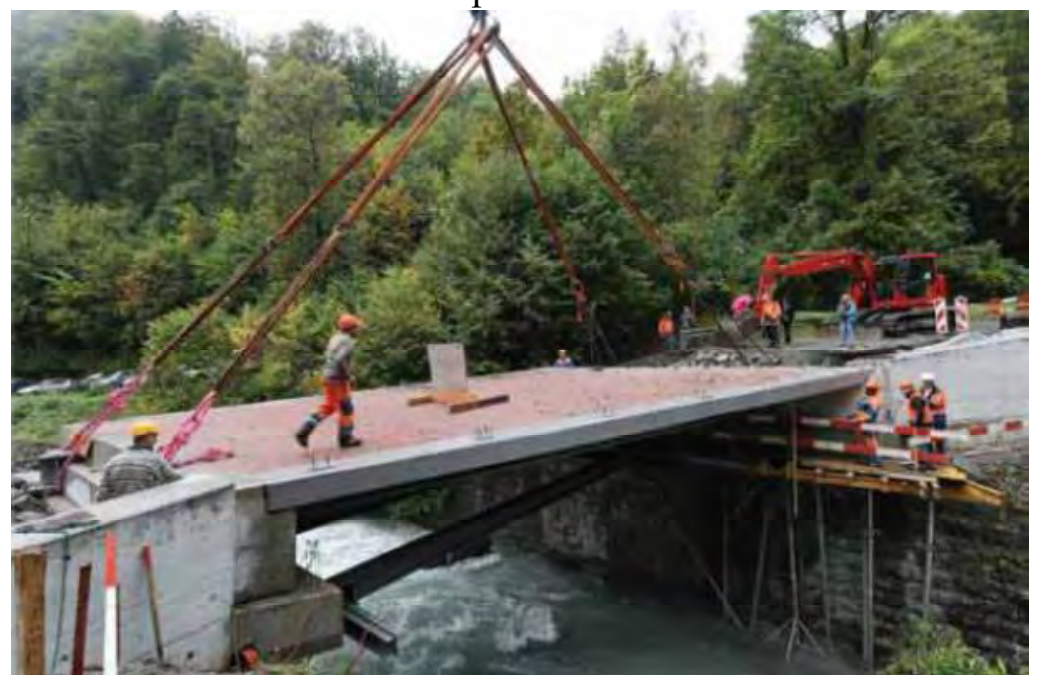

Fonte: Cruz, (2017).

Nogueira de Ó (2009) expõe que as estruturas sanduíche trazem a possibilidade de utilizar cada componente constituinte do elemento no seu limite e também de combinar materiais heterogêneos para formar um compósito que pode viabilizar projetos para aplicações específicas. Projetados com características particulares, as maiores vantagens encontradas pela construção sanduíche são, a elevada rigidez e resistência específica. Desde a aplicação inicial dos materiais compósitos esta característica vem se tornando cada vez mais comum. Os painéis atendem a tensões iguais ou superiores aos dos metais, como os aços e o alumínio, porém, seus Módulos de Elasticidade são mais baixos, o que resulta um comportamento inferior no que diz respeito à estabilidade estrutural. Entretanto, sua aplicação como elemento construtivo é destacada pelo trabalho conjunto do núcleo com as faces que proporcionam a estabilidade exigida, mesmo sob esforços elevados de compressão atendem a demanda se comparados com os valores suportados pelos seus componentes isoladamente.

Manalo (2013) destaca algumas vantagens na construção de residências com painel sanduíche em relação a outros materiais, por ser leve, seu transporte e manuseio durante a montagem ficam facilitados. Características que podem melhorar o tempo de execução de um projeto, facilitar reformas e especialmente a reconstrução de áreas afetadas por calamidades. Uma infinidade de estruturas compósitas sanduíche pode ser aplicada como forro, parede, 
piso e sistemas de subpiso. Em Londres, painéis sanduíche com núcleos de polietileno foram utilizados como paredes e piso em uma construção de dois andares. Na Suíça, um painel sanduíche com função integrada (GFRP), utilizado como cobertura, apresenta propriedades isolantes térmicas, acústicas e hidrófugas, proporcionando um sistema construtivo préfabricado de fácil transporte e instalação (Figura 19).

Figura 19 - Painel sanduíche polimérico reforçado com fibra de vidro para cobertura

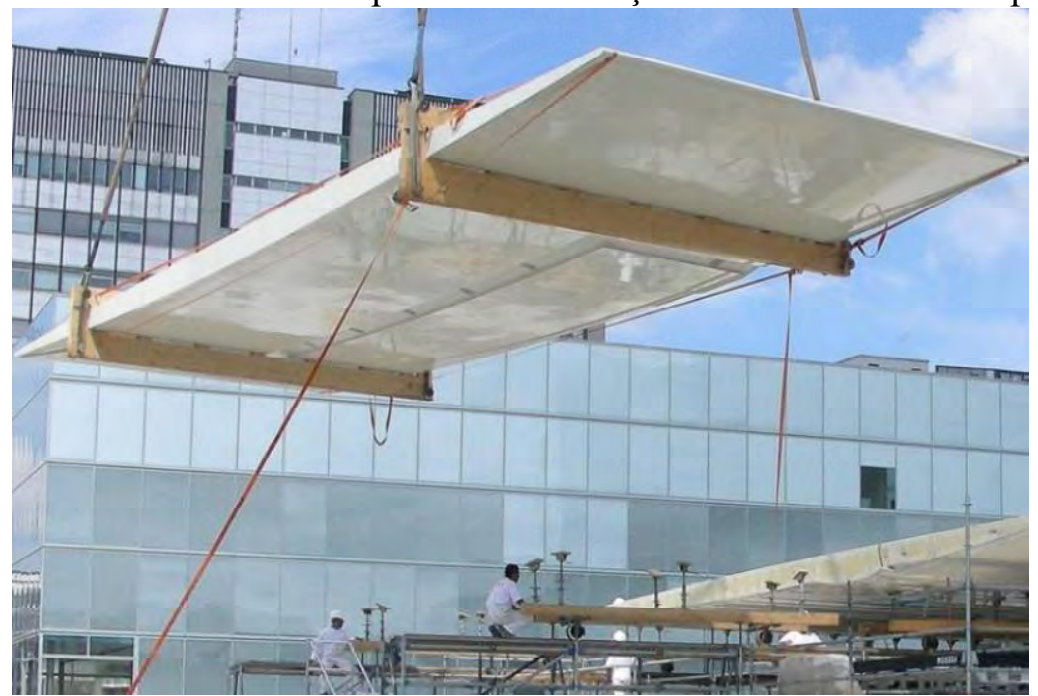

Fonte: Manalo, (2013).

A empresa Knauf Insulation oferece um produto chamado Wood Wool board (Figura 20), fabricado com fibras de madeira aglomeradas com matriz cimentícia, um compósito que de acordo com a empresa pode ser utilizado em isolamento térmico, acústico e contra incêndios na edificação. Alguns campos de aplicação indicados são o revestimento de superfícies de estacionamento, construções em madeira, reabilitação termoacústica de edifícios, subcoberturas e coberturas de telhados residenciais, pisos flutuantes entre outras. As propriedades do painel atende os requisitos da Norma EN 13.168: 2012 Thermal insulation products for buildings - Factory made wood wool (WW) products - Specification, descreve entre as várias aplicações, a utilização na agroindústria, expondo casos em galpões de criação animal que exijam bom fluxo de ar e controle de temperatura, destaca a função de ventilação pelos poros do painel e afirma a capacidade de não contribuir com a transmissão de pestes animais ou vegetais (KNAUF INSULATION FICHA TÉCNICA, 2014). 
Figura 20 - Exemplo de aplicação do painel sanduíche de fibras de madeira como forro isolante térmico em instalação rural

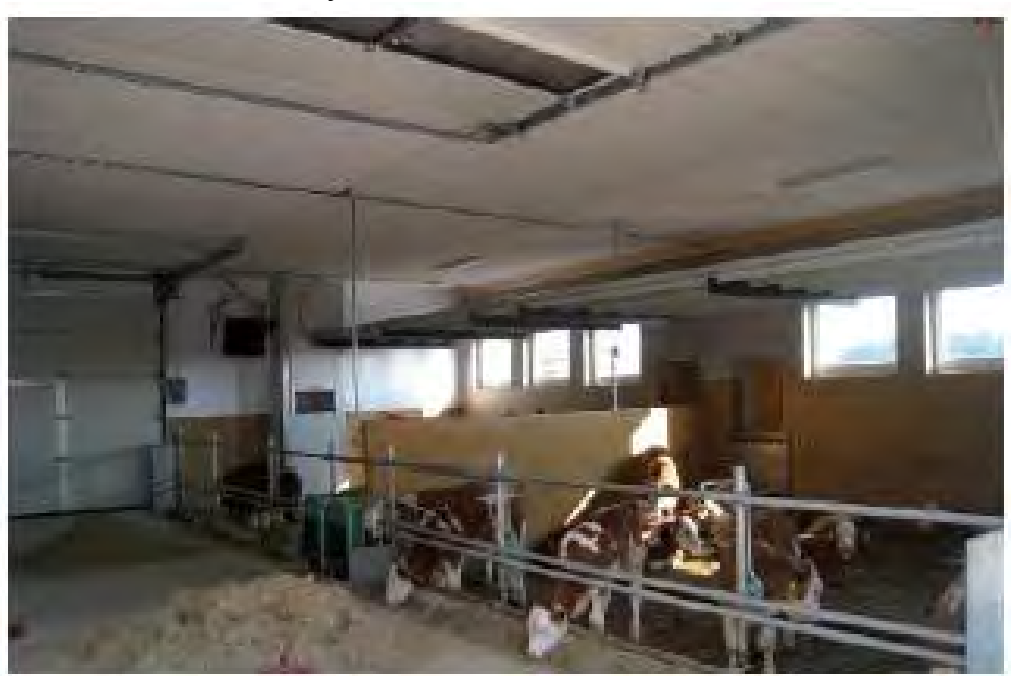

Fonte: Knauf Insulation, (2017).

O painel sanduíche produzido recebe um núcleo de ES ou lã mineral (Figura 21) e pode ser formado por uma ou duas faces, acrescenta que o painel possui propriedades de isolação termoacústica, proteção contra umidade, resistência à compressão e tração na flexão.

Figura 21 - Painel sanduíche de núcleo ES com aplicação para isolação térmica

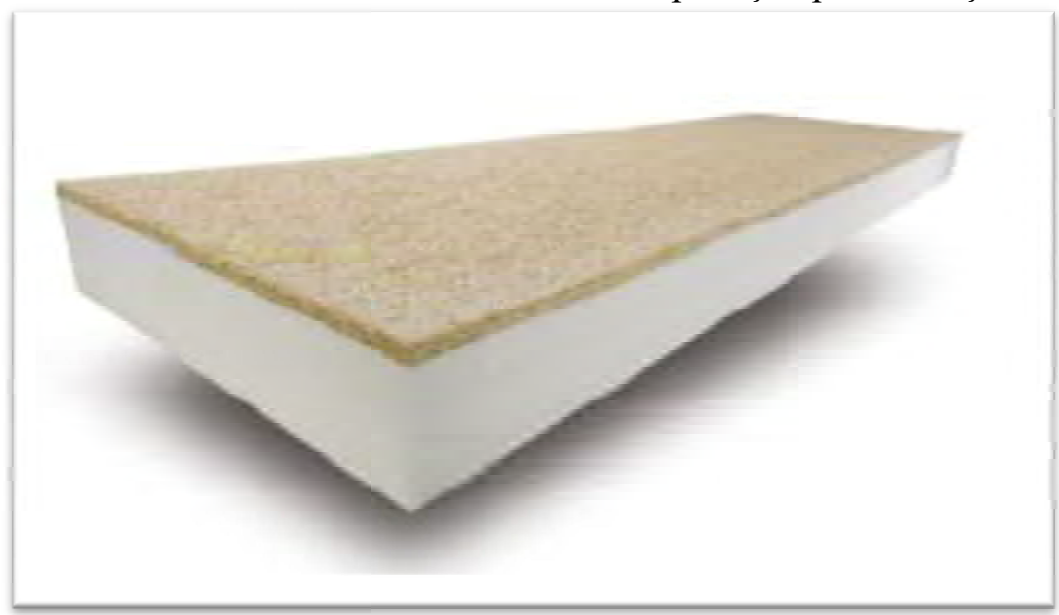

Fonte: Knauf Insulation, (2017).

Patinha (2011) apresenta em seu trabalho sobre construções modulares um sistema chamado Structural Insulated Panels (S.I.P), onde caracteriza-se pela facilidade de execução, é construído em painel sanduíche que inclui isolamento térmico e acústico necessário ao conforto do usuário. Os painéis servem para a construção de paredes, pisos e lajes, são 
formados por placas de OSB (faces) com 1 centímetro de espessura e núcleos de poliuretano expandido com espessura de 8 a 14 centímetros. Os painéis são parafusados em pórticos de perfis metálicos ou de madeira (Figura 22a e Figura 22b).

Figura 22 - Sistema S.I.P de construção residencial em madeira e painéis OSB
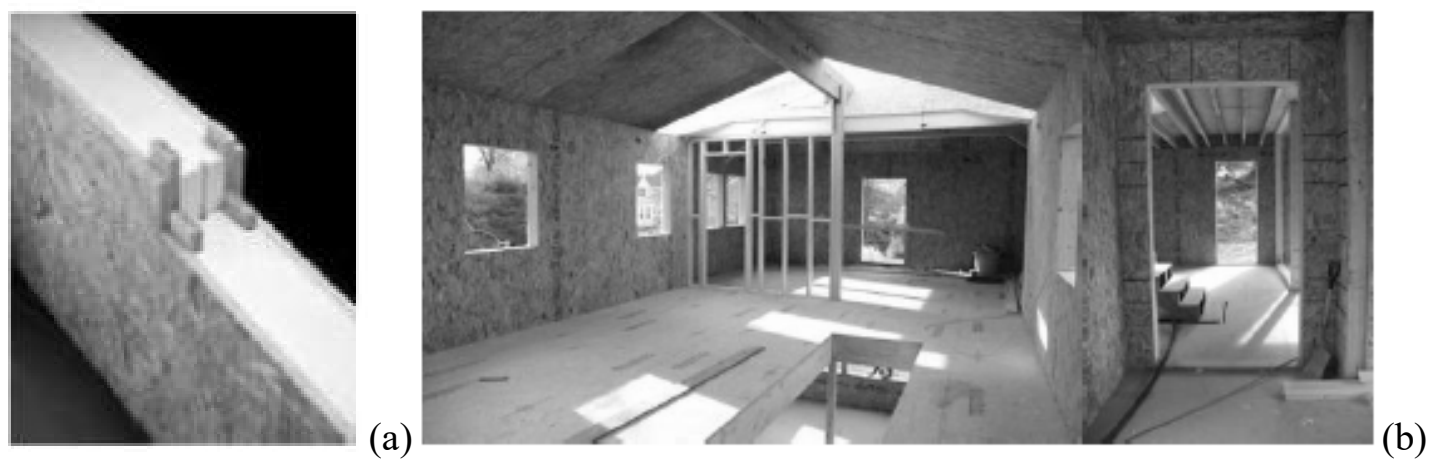

(a) Painel em OSB e poliuretano expandido (b) Interior da residência construída Fonte: Patinha (2011).

Neste item foram apresentadas algumas opções de painéis sanduíche desenvolvidos e aplicados em vários países que demonstraram as possibilidades de utilização deste compósito em sistemas construtivos industrializados. A seguir se apresenta algumas opções de painéis sanduíches produzidos nos setores da indústria da construção civil nacional.

\subsubsection{Características e aplicações dos painéis sanduíche no mercado nacional}

O mercado nacional da construção civil recentemente começou a utilizar os painéis sanduíche. Desenvolvidos com características particulares podem ser aplicados como divisórias, paredes, pisos, forros, mezaninos, passarelas e lajes, possuem resistência a cargas distribuídas, com a condição de vencerem grandes vãos, boa resistência à umidade, excelente isolamento térmico e acústico, resistência a impactos e ao fogo e em alguns casos produzidos com processos que respeitam o meio ambiente (GAGLIARDO, 2008). Conforme exposto pela autora e mesmo com o recente uso do painel sanduíche como um elemento aplicado em sistemas construtivos de vedação o mercado nacional apresenta algumas opções.

A companhia Gypsum S.A. Mineração Indústria e Comércio produz painéis cimentícios para áreas internas que podem ser aplicados como pisos, lajes secas e mezaninos com resistência a cargas de até $500 \mathrm{kgf} / \mathrm{m}^{2}$, porém os apoios devem ser instalados a uma 
distância limite de $1250 \mathrm{~mm}$ e a fixação de parafusos a cada $300 \mathrm{~mm}$ (GUIA DE PRODUTOS GYPSUM, 2017).

A empresa Eternit S.A - Divisão Wall produz componentes para mezaninos, passarelas e forros que aplicados em conjunto com estruturas metálicas compõem um elemento construtivo utilizados em construções industriais, comerciais e hospitalares. $\mathrm{O}$ painel Wall da Eternit é composto por núcleo de madeira maciça, laminada ou sarrafeada, contraplacado por lâminas de madeira e sobrepostas nas faces de placas de fibrocimento, lisas e reforçadas com fibras sintéticas (CRFS - cimento reforçado com fio sintético) (Figura 23), são adesivadas e prensadas a alta temperatura (CATÁLOGO TÉCNICO ETERNIT, 2017).

Figura 23 - Painel sanduíche Eternit com núcleo em madeira laminada e faces de fibrocimento

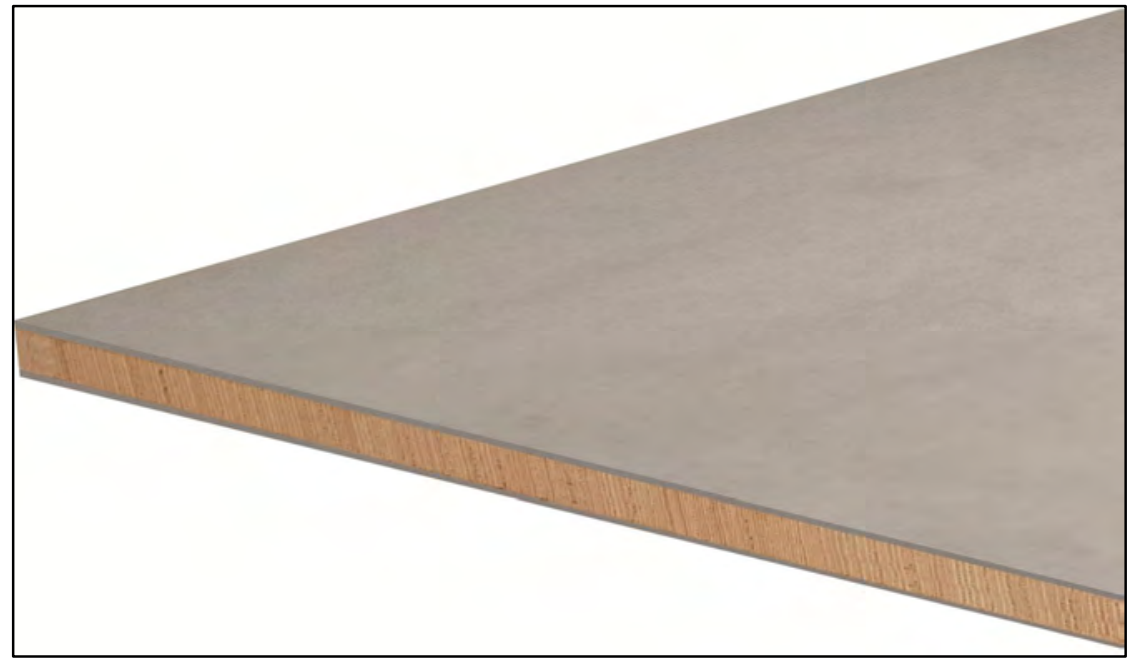

Fonte: Catálogo Eternit, (2017).

Os painéis podem ser cortados e furados com a finalidade de instalar peças e tubulações hidráulicas e elétricas que passam entre as paredes e sua estrutura de fixação. A empresa fornece em seu catálogo algumas propriedades físicas e mecânicas do produto (Quadro 2). 
Quadro 2 - Características físicas do painel sanduíche

\begin{tabular}{|c|c|c|}
\hline \multicolumn{2}{|l|}{ Densidade aproximada } & $\begin{array}{l}40 \mathrm{~mm}: 800 \mathrm{~kg} / \mathrm{m}^{3} \\
55 \mathrm{~mm}: 682 \mathrm{~kg} / \mathrm{m}^{3}\end{array}$ \\
\hline \multicolumn{2}{|c|}{$\begin{array}{l}\text { Resistência a cargas distribuída ( } 3 \text { apoios afastados no máximo } \\
\text { em } 1,25 \text { metros) }\end{array}$} & $550 \mathrm{kgf} / \mathrm{m}^{2}$ \\
\hline \multicolumn{2}{|c|}{ Cargas verticais concentradas } & $150 \mathrm{kgf}$ \\
\hline \multicolumn{2}{|l|}{ Resistência a impactos } & 22.360 Joules (26 impactos) \\
\hline \multicolumn{2}{|l|}{ Cargas suspensas } & $100 \mathrm{kgf}$ \\
\hline \multicolumn{2}{|c|}{ Coeficiente global de transmissão de calor } & $2,18 \mathrm{kcal} / \mathrm{m}^{2} \times \mathrm{h} \mathrm{x}{ }^{\circ} \mathrm{C}$ \\
\hline Comportamento ao fogo & $\begin{array}{l}\text { Isolamento Térmico } \\
\text { Propagação superficial de chamas }\end{array}$ & $\begin{aligned} & 40 \mathrm{~mm}: 50 \mathrm{~min} . \\
& 50 \mathrm{~mm}: 65 \mathrm{~min} . \\
\mathrm{Ip}= & 2(\text { Classe/NBR } 9442)\end{aligned}$ \\
\hline
\end{tabular}

Fonte: Catálogo Eternit, (2017).

Similarmente, a empresa Decorlit produz o Painel Wall (núcleo de madeira) e o Painel Facility EPS (“núcleo de isopor”) (Figura 24), composto por um núcleo de poliestireno expandido contraplacado nas duas faces por placas de fibrocimento CCFS (cimento, celulose e fio sintético), possui baixa densidade e uso específico (CATÁLOGO DECORLIT, 2017).

Figura 24 - Painel sanduíche com núcleo em poliestireno expandido e faces de fibrocimento

Fonte: Catálogo Decorlit, (2017).

A empresa informa que o produto pode ser utilizado como divisórias, paredes e forros, em câmaras frias ou entre outros ambientes. Componente para um sistema construtivo a seco, de uso interno e externo, pode ser aplicado em obras residenciais, comerciais, industriais e de saúde. Os painéis possuem dimensões que variam entre $1200 \mathrm{~mm}$ de largura por 2500 a $3000 \mathrm{~mm}$ de comprimento por 35 a $120 \mathrm{~mm}$ de espessura, com peso variando entre 
43,3 e 76,5 kg por peça apresenta baixa densidade. A empresa fornece em seu catálogo várias características físicas, mecânicas e térmicas do produto (Quadro 3).

Quadro 3 - Ensaios realizados e características físicas do painel sanduíche

\begin{tabular}{|c|c|c|}
\hline Aprovado pela NBR 15.575 - Parte 4 & \multicolumn{2}{|c|}{$\begin{array}{l}\text { Ensaio: CCC 149.030-1/08; 149.030- } \\
\text { 2/08 e 149.030-/08 - Falcão Bauer }\end{array}$} \\
\hline Segurança estrutural & \multicolumn{2}{|c|}{$\begin{array}{l}\text { Ensaio: CCC 214.914-1/11e 214.914- } \\
\text { 2/11- Falcão Bauer }\end{array}$} \\
\hline Estabilidade e resistência estrutural dos sistemas de vedação & \multicolumn{2}{|c|}{ 214.914-2/11-Falcão Bauer } \\
\hline Segurança ao fogo & \multicolumn{2}{|c|}{$\begin{array}{l}\text { Laudo: EE/11208/06 e relatório de } \\
\text { ensaio } 906.884\end{array}$} \\
\hline $\begin{array}{l}\text { Condutividade Térmica (Quanto menor o valor mais isolante é } \\
\text { o material). } \\
\text { Referências: Concreto }=1,70 \mathrm{~W} / \mathrm{mK} \text { e Lã de vidro ou rocha }= \\
0,040 \mathrm{~W} / \mathrm{mK}\end{array}$ & \multicolumn{2}{|c|}{ Painel Facility Wall $(\mathrm{W} / \mathrm{mK})=0,059$} \\
\hline $\begin{array}{l}\text { Resistência Térmica (Quanto maior o valor maior o conforto } \\
\text { térmico); Painel Facility Wall } \\
\text { (pela espessura do painel) } \\
\text { Referência: Tijolo de } 100 \mathrm{~mm}=0,11 \mathrm{k} / \mathrm{W}\end{array}$ & $\begin{array}{l}35 \mathrm{~mm} \\
70 \mathrm{~mm} \\
90 \mathrm{~mm} \\
120 \mathrm{~mm}\end{array}$ & $\begin{array}{l}0,52 \mathrm{~K} / \mathrm{W} \\
1,25 \mathrm{~K} / \mathrm{W} \\
1,52 \mathrm{~K} / \mathrm{W} \\
2,11 \mathrm{~K} / \mathrm{W}\end{array}$ \\
\hline
\end{tabular}

Fonte: Catálogo Decorlit, (2017).

A empresa Brasilit do Grupo Sant Gobain, apresenta um produto com diversas aplicações similares aos seus concorrentes (MANUAL DE MONTAGEM, 2013), um exemplo específico encontrado em seu manual é o painel sanduíche utilizado como elemento de um sistema construtivo a seco para escadas (Figura 25).

Figura 25 - Sistema construtivo a seco para escada e pisos de painéis sanduíche

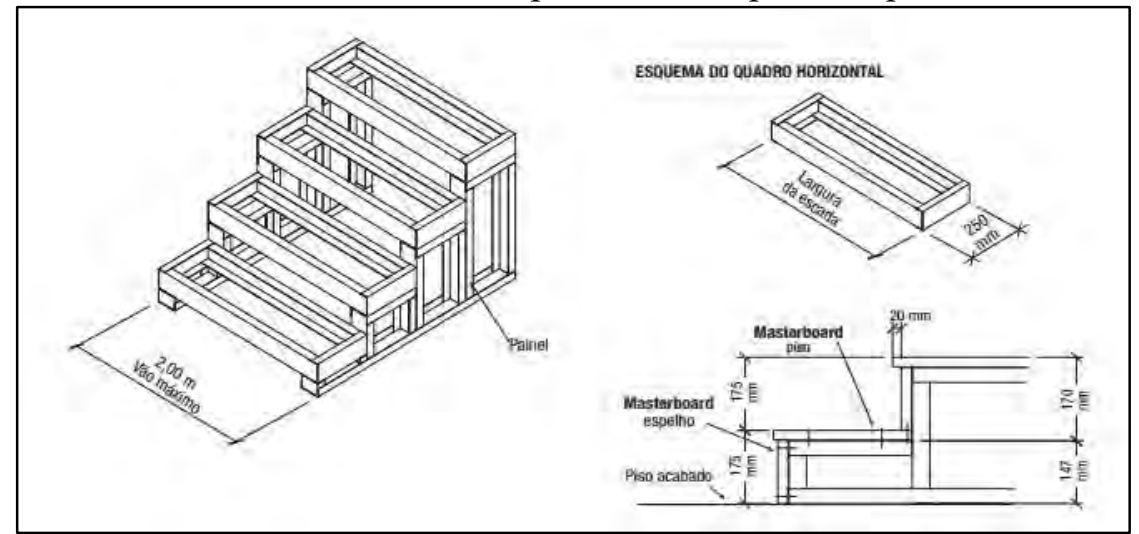

Fonte: Manual de montagem Brasilit, (2013). 
Entre outras possibilidades apresentadas, o fabricante orienta a aplicação do painel em ambientes internos, respeitando sua espessura de acordo com o uso e carga a ser aplicada. O guia do fabricante descreve as diretrizes de aplicação de carga conforme a norma ABNT NBR 6120 - Cargas para o cálculo de estruturas em edifícios. Com isso o guia Brasilit determina a espessura e o número de apoios necessários por painel sanduíche para servir como piso de um mezanino, por exemplo, (Quadro 4). Em seu guia de sistema, entre as características físicas e mecânicas, foi admitido uma resistência média à tração na flexão de 9 MPa de tensão para o painel de densidade igual a $1,25 \mathrm{~g} / \mathrm{cm}^{3}$ (GUIA DE SISTEMAS PARA PRODUTOS PLANOS, 2011).

Quadro 4 - Cargas máximas de utilização do painel sanduíche

\begin{tabular}{|c|c|c|c|}
\hline Espessura dos painéis & Largura dos painéis & Número de apoios & Carga máxima \\
\hline $23 \mathrm{~mm}$ & $2400 \mathrm{~mm}$ & 4 & $300 \mathrm{kgf} / \mathrm{m}^{2}$ \\
\hline $40 \mathrm{~mm}$ & 2000 e $2500 \mathrm{~mm}$ & 3 & $500 \mathrm{kgf} / \mathrm{m}^{2}$ \\
\hline $40 \mathrm{~mm}$ & 2750 e $3050 \mathrm{~mm}$ & 4 & $500 \mathrm{kgf} / \mathrm{m}^{2}$ \\
\hline
\end{tabular}

Fonte: Guia de sistemas para produtos planos Brasilit, (2011).

Para instalação de pisos elevados a norma ABNT NBR 11802: 1991 - Pisos elevados - Especificação atribui à placa de madeira aglomerada de alta densidade encapsulada em aço, os requisitos de $12 \mathrm{KPa}$ para carga uniformemente distribuída (0,012 MPa) e $4400 \mathrm{KPa}$ para carga concentrada admissível (4,40 MPa) (ASSOCIAÇÃO BRASILEIRA DE NORMAS TÉCNICAS, 1991).

A LP Building Products Brasil (empresa filial da Lousiana Pacific Corporation) sediada em Curitiba desde 2008, apresenta vários produtos para a construção civil aplicado mundialmente. Desde coberturas shingle, placas OSB, subcoberturas (manta térmica), painéis revestidos de materiais como alumínio, vinil, fenólicos, PVC entre outros, a empresa produz um painel de fibrocimento com núcleo de madeira reconstituída, desenvolvido como um elemento para um sistema construtivo a seco pode proporcionar agilidade à construção, (CATÁLOGO TÉCNICO LP BRASIL, 2012). Com espessuras variadas o núcleo é feito com um painel OSB (painel de partículas do tipo maravalha) e as faces em placa de fibrocimento sem amianto (Figura 26). 
Figura 26 - Painel sanduíche com núcleo de madeira reconstituída

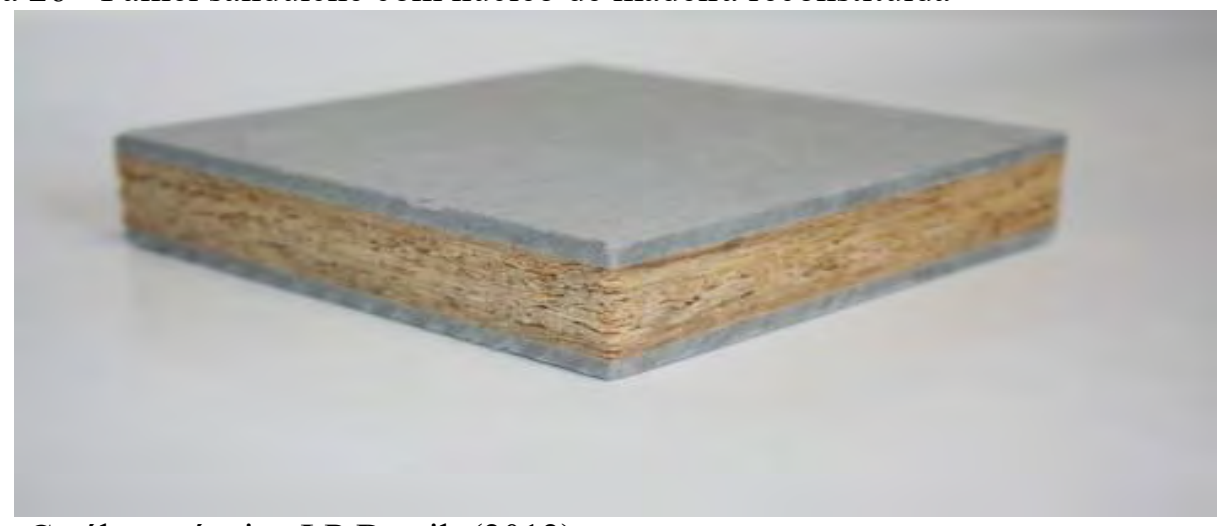

Fonte: Catálogo técnico LP Brasil, (2012).

A empresa sugere algumas aplicações para o painel sanduíche como mezaninos, lajes secas e paredes divisórias. Algumas especificações técnicas do painel da LP Building Products Brasil para mezaninos e lajes secas são similares aos concorrentes e apresentadas no (Quadro 5).

Quadro 5 - Especificações do painel sanduíche com faces de fibrocimento para mezanino e laje seca

\begin{tabular}{|c|c|c|c|c|}
\hline Espessura dos painéis & $\begin{array}{c}\text { Dimensões dos } \\
\text { painéis }\end{array}$ & $\begin{array}{c}\text { Número de } \\
\text { apoios }\end{array}$ & Carga máxima & Peso \\
\hline $23 \mathrm{~mm}$ & $1,20 \times 2,50 \mathrm{~m}$ & 4 & $500 \mathrm{kgf} / \mathrm{m}^{2}$ & $23,30 \mathrm{~kg} / \mathrm{m}^{2}$ \\
\hline $40 \mathrm{~mm}$ & $1,20 \times 2,50 \mathrm{~m}$ & 3 & $500 \mathrm{kgf} / \mathrm{m}^{2}$ & $31,20 \mathrm{~kg} / \mathrm{m}^{2}$ \\
\hline $40 \mathrm{~mm}$ (fenólico) & $1,20 \times 2,50 \mathrm{~m}$ & 3 & $500 \mathrm{kgf} / \mathrm{m}^{2}$ & $24,00 \mathrm{~kg} / \mathrm{m}^{2}$ \\
\hline
\end{tabular}

Fonte: Catálogo LP Brasil, (2012).

Quase todos os fabricantes apresentam em seus catálogos as propriedades físicas, mecânicas e térmicas de seus produtos, sempre referenciando empresas certificadoras renomadas no mercado. Portanto a caracterização dos materiais e produtos apresentados sob as diretrizes de normas nacionais e internacionais pode proporcionar qualidade e confiabilidade, importante também que o fabricante transmita aos usuários consumidores, projetistas e pesquisadores como utilizar o produto e direcionar dimensionamentos de aplicação e tempo de vida útil. Os itens a seguir apresentam discussões sobre as análises das propriedades dos painéis e algumas normas que podem ser aplicadas na caracterização do compósito. 


\subsubsection{Especificações dos ensaios em painéis sanduíche: núcleos e faces}

As normas aplicadas para a caracterização das estruturas sanduíche são variadas de acordo com os materiais empregados nas faces e núcleos, bem como suas formas geométricas. A ASTM (American Society for Testing and Materials) estabelece um conjunto de normas que sobre condições específicas permite avaliar as seguintes propriedades segundo (NOGUEIRA DE Ó. 2009): (i) resistência à flexão; (ii) tensão de cisalhamento do núcleo; (iii) módulo de rigidez do núcleo; (iv) tensões de tração e compressão nas faces e (v) propriedades da ligação adesiva núcleo-face.

Segundo Gagliardo (2008) analisando as diretrizes da norma ASTM C393-62 Standard Test Method for Flexural Properties of Sandwish Construction para o ensaio de flexão, pode-se obter tanto informações sobre as propriedades globais do comportamento do painel sanduíche quanto de seus componentes individualmente conforme descrito a seguir: (i) resistência á tração e à compressão das faces; (ii) rigidez do conjunto; (iii) módulo de elasticidade do núcleo e (iv) resistência cisalhante do núcleo. O (Quadro 6) apresenta algumas normas internacionais que propõem metodologias de ensaios para painéis sanduíche segundo a autora.

Quadro 6 - Normas referenciadas em algumas pesquisas sobre painel sanduíche

\begin{tabular}{|c|c|}
\hline \multicolumn{2}{|c|}{ Normas internacionais aplicáveis a painéis sanduíche } \\
\hline Designação & Assunto/Propriedades \\
\hline ASTM C393-00 & Métodos de ensaio das propriedades na flexão do sanduíche \\
\hline ASTM C364/C364M-07 & Método de ensaio de compressão coplanar (longitudinal) do painel \\
\hline ASTM C365-05 & Método de ensaio de compressão plana (perpendicular) do núcleo \\
\hline ASTM D1781-98(2004) & Método de ensaio de deslocamento de face (resistência ao cisalhamento \\
\hline
\end{tabular}

Fonte: Adaptado Gagliardo, (2008).

Interpretando a norma ASTM C393/C393M 11 Standard Test Method for Core Shear Properties of Sandwich Construction by Bean Flexure conforme item 5 (Significance and Use) os testes de flexão em painéis sanduíche pode conduzir a determinação das seguintes propriedades: (i) rigidez na flexão; (ii) tensão de tração e módulo de cisalhamento do núcleo; (iii) tensão de tração e compressão da face. Testes que avaliam a tração de cisalhamento de núcleo podem também ser aplicados para aferir a tensão de ligação núcleo-face. 
Nos últimos 10 anos um comitê da ASTM revisou e avaliou a evolução das normas para a caracterização das propriedades físicas e mecânicas de compósitos sanduíches. A revisão feita pelo comitê ASTM D30.09 (Quadro 7) apresentou um resumo com o intuito de fornecer a comunidade internacional de pesquisadores de compósitos a seleção dos principais métodos de testes para a caracterização dos painéis sanduíche (ASTM D30 COMMITTE ON COMPOSITE MATERIALS, 2009).

Quadro 7 - Resumo de algumas normas revisadas e avaliadas pelo comitê ASTM D30 no ano de 2009

\begin{tabular}{|c|c|}
\hline \multicolumn{2}{|c|}{ D30.09 ASTM Committee - Core material and Sandwich Structure Standards } \\
\hline Designação & Componente \\
\hline Core Material Standards & Acess Properties \\
\hline C271/C271M-05 & Core Density \\
\hline C 272-07 & Core Water Absorption \\
\hline C 273/C 273M-07 & Core Shear Properties \\
\hline C 363-00 & Honeycomb Core Node Tensile Strength \\
\hline C 365/C 365M-05 & Core Flatwise Compressive Properties \\
\hline C 366/C 366M-05 & Core Thickness Measurement \\
\hline C 393/C 393M-06 & Core Shear Properties by Beam Flexure \\
\hline C 394-08 & Core Shear Fatigue \\
\hline D 6772-07 & Core Dimensional Stability \\
\hline D 6790-07 & Honeycomb Core Poisson's Ratio \\
\hline D 7336/D 7336M-07 & Honeycomb Core Static Energy Absorption \\
\hline F 1645/F 1645M-07 & Honeycomb Core Water Migration \\
\hline Sandwich Structure Standards & Acess Properties \\
\hline C 274/C 274M-07 & Sandwich Terminology \\
\hline C 297/C 297M-07 & Sandwich Flatwise Tensile Strength \\
\hline C 364/C 364M-07 & Sandwich Edgewise Compressive Strength \\
\hline C 480-08 & Sandwich Flexural Creep \\
\hline C 481-05 & Sandwich Laboratory Aging \\
\hline D 6416/D 6416M-07 & Sandwich 2D Plate Flexural Properties \\
\hline D 7249/D 7249M-06 & Sandwich Facing Properties by Beam Flexure \\
\hline D 7250/D 7250M-06 & Practice for Sandwich Beam Flexural \& Shear Stiffness \\
\hline
\end{tabular}

Fonte: Adaptado do Boletim ASTM D30.09, (2009).

Por décadas as instituições normativas de todo mundo buscam continuamente revisar e desenvolver novos métodos para melhorar a qualidade de avaliação das amostras 
compósitas, com o intuito de auxiliar o desenvolvimento, caracterização e aplicação de novos materiais e estruturas para diversos fins.

\subsubsection{Significância e propósito da norma ASTM 393/393M - 11}

A composição deste item foi produzida da análise e interpretação da norma ASTM 393/393M - 11 Standard test Method for Core Shear Properties of Sandwich Construction by Beam Flexure onde se descreve parte do método de caracterização e determinação das propriedades de núcleo e faces do painel sanduíche. Quando o painel é submetido à flexão, de modo que a aplicação do momento produza curvatura na amostra, a análise mecâqnica é iniciada. Os materiais do núcleo podem ser compostos por elementos de adesão contínua ou descontínua às faces, como a madeira balsa e materiais expandidos ou estruturas alveolares como a colmeia de abelha (favo de mel) respectivamente ASTM C393/C393M - 11 (AMERICAM SOCIETY FOR TESTING AND MATERIALS, 2011).

O método consiste em submeter uma viga do painel sanduíche a um momento na flexão normal ao plano de suas faces, medindo a força versus a deflexão do painel. Os modos de falhas aceitas são de cisalhamento de núcleo ou de adesão de núcleo-face. Falhas de faces de painel precedendo falhas de núcleo ou adesão de face e núcleo não são aceitas como modo de falhas para a ASTM 393/393M - 11. Para esse tipo de falha se recomenda seguir o método D7249/D7249M - 12 onde se determina a tração na face do painel sanduíche ASTM C393/C393M - 11 (AMERICAM SOCIETY FOR TESTING AND MATERIALS, 2011).

Teste de flexão em estruturas horizontais tipo sanduíche podem conduzir a determinação da rigidez na flexão, resistência ao cisalhamento de núcleo e módulo de cisalhamento ou de compressão de face e resistência à tensão. Este método objetiva obter a resistência ao cisalhamento de núcleo ou de cisalhamento entre núcleo e face e rigidez do painel sanduíche. Para obter o histórico de deflexão de carregamento para dimensionamento à flexão e rigidez ao cisalhamento do painel, se utiliza o método da Norma ASTM D7250/D7250M - 12. Melhores resultados de resistência de face podem ser determinados em acordo com a mesma norma ASTM C393/C393M - 11 (AMERICAM SOCIETY FOR TESTING AND MATERIALS, 2011).

Todos os testes e métodos citados podem ser legitimados como referência e modo de obtenção de dados para a produção de projetos de painéis sanduíche, especificação de 
materiais, pesquisa e desenvolvimento de aplicações e ainda ser utilizado como controle de qualidade para testes de resinas para painéis. Estes fatores podem influenciar os relatórios que incluem: (i) materiais para a produção de faces e núcleos; (ii) produção de adesivos; (iii) métodos de fabricação de materiais; (iv) geometria de núcleos (tamanho das células); (v) densidade de núcleo; (vi) espessura de adesivos; (vii) preparação, condicionamento e geometria de amostras; (viii) condições ambientais de teste; (ix) procedimento de aplicação de carga e (x) potencial de vazios em adesivos ASTM C393/C393M - 11 (AMERICAM SOCIETY FOR TESTING AND MATERIALS, 2011).

Algumas interferências podem ocorrer na utilização deste método influenciando na coleta de dados e resultados para as aplicações citadas. A seguir a descrição de algumas interferências citadas na ASTM C393/C393M - 11 (AMERICAM SOCIETY FOR TESTING AND MATERIALS, 2011):

(i) Material e preparação de amostras - Danos e deficiência na qualidade da produção de informação são induzidos pela preparação inadequada de amostras. Podem causar coleta de dados dispersos sobre os compósitos e estruturas sanduíche avaliadas. Um fator específico de material que afeta o núcleo do sanduíche é a variação da densidade do material que o compõem. Outros aspectos incluem a existência de juntas, vazios ou descontinuidade do núcleo, curvaturas excêntricas e ondulações da superfície do núcleo.

(ii) Geometria - Fator que afeta a resistência ao cisalhamento do núcleo que incluem a ortotropia (células na direção longitudinal contra a transversal para materiais de núcleo de colmeia) e geometria das células.

(iii) Meio ambiente - Os resultados podem ser afetados pelas condições ambientais de laboratório e como as amostras são acondicionadas. As condições podem alterar as características dos materiais que compõem núcleo, faces e adesivos.

(iv) Materiais de núcleo - Se o material do núcleo apresentar resistência ao cisalhamento e compressão insuficientes pode ocorrer rupturas localizadas e próximas ao ponto de carregamento, assim associar falhas nas faces no local de estresse. Em outros casos, falhas nas faces podem causar rupturas de núcleo. Quando ocorrer ambos os casos em regiões próximas, pode ser difícil se identificar a causa da sequência de falhas durante a inspeção pós-ruptura da amostra, pois a ocorrência se mostra muito similar. 
A metodologia apresenta configurações de aplicação de cargas que consistem em locações de corpos de provas em 3 e 4 pontos, onde o suporte de carga de uma ou duas barras é locado no topo da amostra e a força deve ser aplicada verticalmente às barras de suporte da máquina de teste. A configuração padrão de carga deve ser de três pontos, centralizada sobre os suportes de barra separados por uma distância de $150 \mathrm{~mm}$ (Figura 27).

Figura 27 - Configurações padrão de carga (Standard and Non-Standard Configuration)

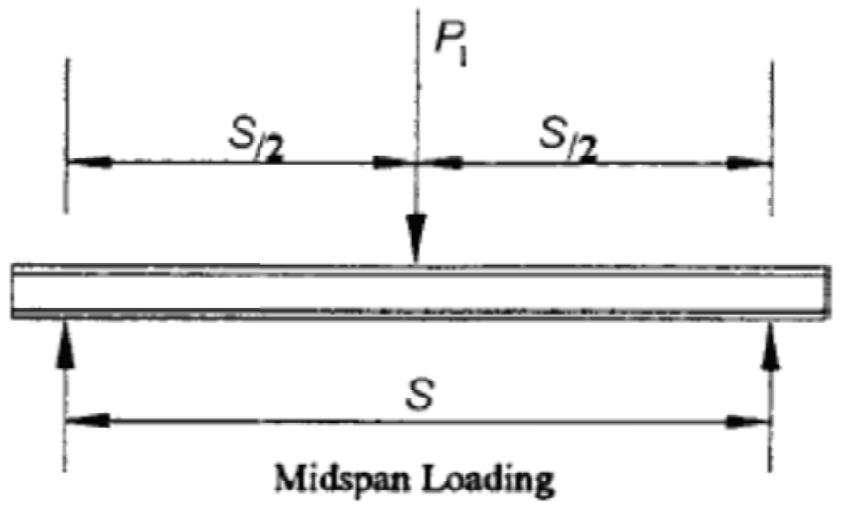

(a) Locação em 3 pontos (3-Point Loading - Standard Configuration)

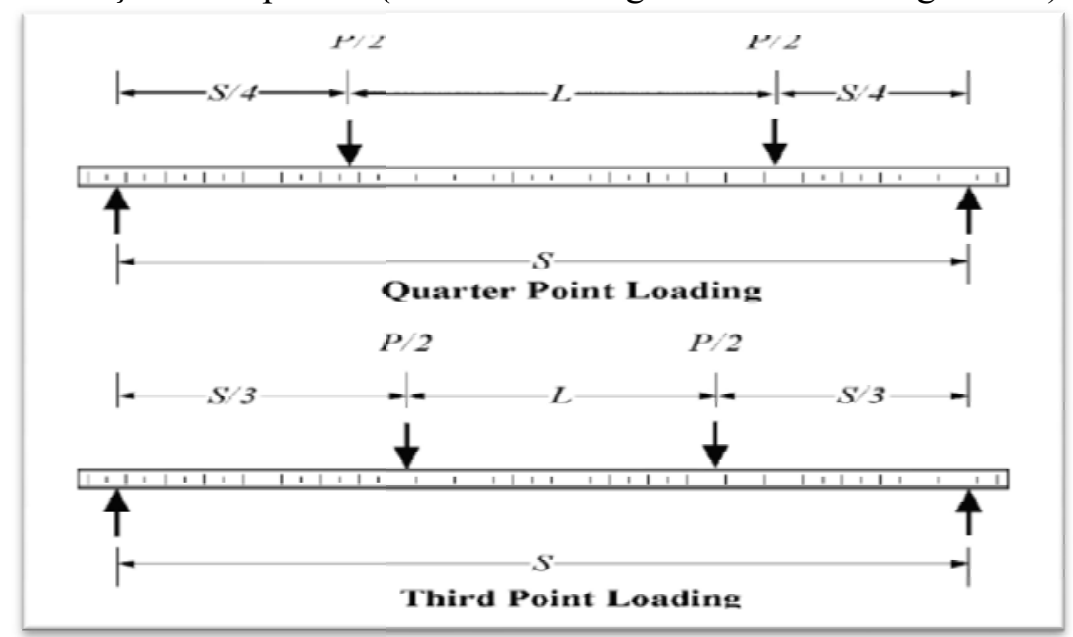

(b) Locação em 4 pontos (4-Point Loading - Non-Standard Configuration) Fonte: ASTM 393/C393M-2011, (2011).

Qualquer outra configuração é denominada fora do padrão, os detalhes da geometria de carga devem ser documentados no relatório como mostra a (Figura 27), uma típica configuração de carga de quatro pontos para vigas curtas de painel sanduíche. Configurações 
3 e 4 pontos não padronizadas podem ser utilizadas quando: (i) para uma continuidade histórica de teste anteriores executados de acordo com outras versões da Norma ASTM C393 que devem ser finalizadas; (ii) algumas amostras de painéis sanduíche requerem o uso da configuração não conforme à norma para atingirem os modos de falhas de núcleo ou adesão de núcleo e face e (iii) seguir as configurações da norma ASTM D7255/D7255M para a obtenção de dados sobre deflexão e rigidez ao cisalhamento ASTM C393/C393M - 11 (AMERICAM SOCIETY FOR TESTING AND MATERIALS, 2011).

A amostragem e os corpos de prova seguem o mesmo princípio da metodologia de posicionamento de carga, ou seja, para configurações padronizadas ou não. As quantidades de amostras são cinco, as amostras padronizadas devem ter seção retangular medindo $75 \mathrm{~mm}$ de largura e $200 \mathrm{~mm}$ de comprimento, a espessura da amostra deve ser a mesma do painel a ser construído. As amostras não padronizadas devem ser preparadas com largura maior que duas vezes e menor que seis vezes a espessura do painel, maior que três vezes a espessura do núcleo e menor que metade da distância entre os apoios do corpo de prova determinado para configurações não padronizadas. O comprimento da amostra deve ser igual a distância entre os apoios como descrito mais $50 \mathrm{~mm}$ ou duas vezes a espessura do painel sanduiche ASTM C393/C393M - 11 (AMERICAM SOCIETY FOR TESTING AND MATERIALS, 2011).

Figura 28 - Configuração de carga quatro pontos para painel sanduíche

Fonte: ASTM 393/C393M-2011, (2011). 
A geometria das amostras segue as diretrizes da norma que indica que o corpo de prova deve produzir falhas de núcleo e núcleo com a face, situação ideal para a sua avaliação. Dimensões apropriadas das amostras para o teste de flexão pode determinar a resistência desejada de projeto do painel ao cisalhamento do núcleo ou adesão de núcleo com a face, que são requisitos que podem evitar falhas na futura construção do painel. As faces devem ser suficientemente espessas para que as forças de cisalhamento não produzam estresse excessivo. Equações podem ser utilizadas para dimensionar as amostras de teste, e assumem que ambas as faces tem a mesma espessura e modulo de rigidez, e que a espessura da face em relação ao núcleo respeite a condição $\mathrm{t} / \mathrm{c} \leq \sim 0,10$, ainda considera-se que a distância do suporte de apoio da amostra satisfaça condições descritas pela ASTM C393/C393M - 11 (AMERICAM SOCIETY FOR TESTING AND MATERIALS, 2011) como seguem:

$$
S \leq \frac{2 K \sigma t}{F S}+L
$$

Ou que resistência ao cisalhamento do núcleo atenda:

$$
F \leq \frac{2 K \sigma t}{(S-L)}
$$

E que a resistência à compressão do núcleo atinja:

$$
F \geq \frac{2(c+t) \sigma t}{(S-L) \operatorname{lpad}}
$$

Onde:

$\mathrm{L}=$ loading span lenght, $\mathrm{mm}$;

$\sigma=$ expected facing ultimate strength, $\mathrm{MPa}$;

$\mathrm{t}=$ facing thickness, $\mathrm{mm}$;

$\mathrm{c}=$ core thickness, mm (Figura 29);

Fs = estimated core shear strength, $\mathrm{MPa}$;

$\mathrm{k}=$ facing strength factor to ensure core failure (recommended $\mathrm{k}=0,75$ );

lpad = dimension of loading pad in specimen lengthwise direction, $\mathrm{mm}$; e

$\mathrm{Fc}=$ core compression allowable strength, $\mathrm{MPa}$. 
Figura 29 - Representação das dimensões em espessura de um tipo de painel sanduíche

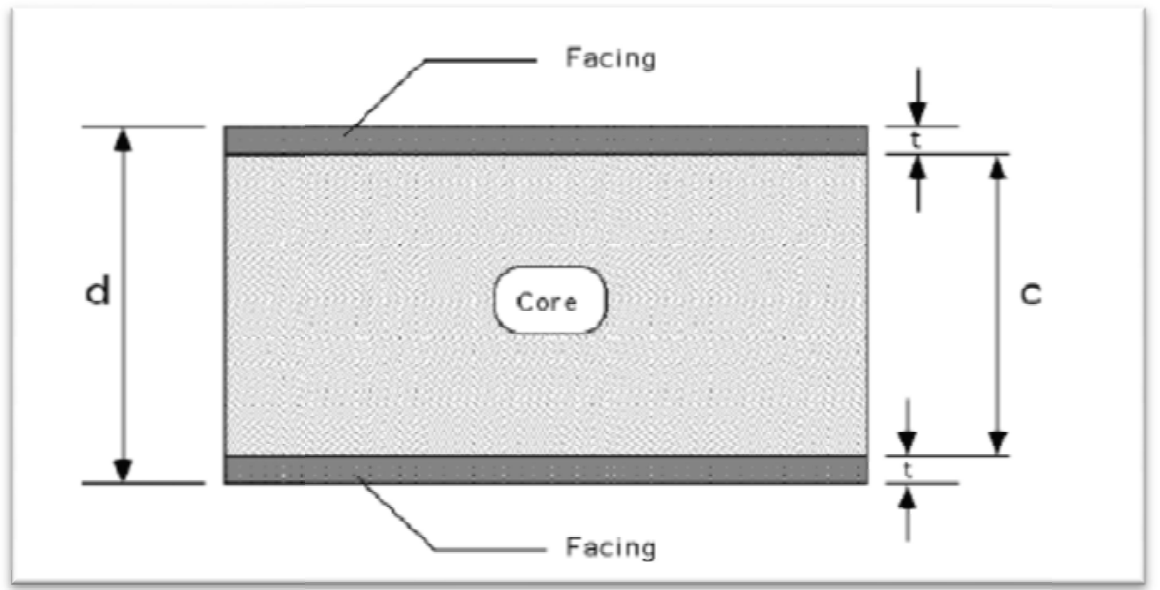

Fonte: ASTM 393/C393M-2011, (2011).

A validação das propriedades testadas das amostras não deve ser aceita para aquelas que apresentarem alguma falha ou ruptura brusca (repentina como um colapso estrutural), a menos que tal falha constitua uma variável em estudo. Os novos testes serão feitos para os mesmos tipos de amostras descartadas. Quando uma fração (população) significante de amostras sofrer fraturas em uma ou ambas as faces a geometria do corpo de prova e a configuração do carregamento devem ser reexaminados ASTM C393/C393M - 11 (AMERICAM SOCIETY FOR TESTING AND MATERIALS, 2011).

Os registros dos dados e tipos de ruptura devem ser identificados e reportados seguindo os códigos e orientações da norma (Quadro 8). Os modos iniciais de falha devem ser observados no relatório e incluem as seguintes características: (i) delaminação da placa ou placas que compõem a face; (ii) descolamento do núcleo da face; (iii) fratura parcial do núcleo e (iv) ruptura local do núcleo. Os métodos de coleta de dados podem ser visual, acústico e eletrônico, observando a força máxima de ruptura; a deflexão máxima do dispositivo de carga tão próximo quanto possível do momento da ruptura ASTM C393/C393M - 11 (AMERICAM SOCIETY FOR TESTING AND MATERIALS, 2011). 
Quadro 8 - Códigos de identificação das falhas do painel sanduíche na configuração de carga em três pontos

\begin{tabular}{|l|c|c|c|c|c|}
\hline \multicolumn{2}{|c|}{ First Character } & \multicolumn{2}{c|}{ Second Character } & \multicolumn{2}{c|}{ Third Character } \\
\hline Failure Type & Code & $\begin{array}{c}\text { Failure } \\
\text { Area }\end{array}$ & Code & $\begin{array}{c}\text { Failure } \\
\text { Location }\end{array}$ & Code \\
\hline Core Crushing & C & At load bar & A & Core & C \\
\hline Skin to core Delamination & D & Gage & G & $\begin{array}{c}\text { Core-facing } \\
\text { Bond }\end{array}$ & A \\
\hline Facing failure & F & $\begin{array}{c}\text { Multiple } \\
\text { areas }\end{array}$ & M & Bottom facing & B \\
\hline Multi-mode & M(xyz) & Outside gage & O & Top facing & T \\
\hline Transverse Shear & S & Various & V & Both Facing & F \\
\hline EXplosive & X & Unknown & U & Various & V \\
\hline Other & O & & & Unknown & U \\
\hline
\end{tabular}

Fonte: Adaptado ASTM 393/C393M-2011, (2011).

\subsubsection{Comportamentos mecânico e falhas estruturais de painéis sanduíche}

Segundo Nogueira do Ó (2009) durante o desenvolvimento do projeto de uma viga, o projetista está preocupado com as tensões as quais a viga está submetida e também as deflexões causadas. Uma deflexão máxima pode ser estipulada e não deve ultrapassar uma pequena porcentagem do vão de apoio. Ainda de acordo com o autor, para materiais isotrópicos e pequenas deformações, as vigas são calculadas em flexão com boa precisão, considerando que os esforços de cisalhamento são desprezados. Continua expondo que os estudos que desprezam os esforços transversais (considerando os longitudinais), provenientes da contribuição da deflexão, adotam a viga em estado de flexão pura, o que significa estar sujeita apenas a esforços binários de igual intensidade e sentidos opostos, e neste caso são nomeadas de vigas de Euler-Bernoulli.

Acrescenta que no caso de materiais compósitos como a viga sanduíche, as deformações causadas pelos esforços cisalhantes devem ser consideradas no cálculo da deflexão. Analisando as hipóteses de Bernulli, em que a seção transversal de uma barra sob flexão permanece plana e perpendicular ao eixo longitudinal mesmo depois da deformação, nega-se a segunda hipótese afirma o autor, isto porque a seção transversal não se mantém 
necessariamente perpendicular ao eixo longitudinal. Assim ao considerar a deflexão e que a seção não permanece perpendicular e somente plana, é usual adotar a hipótese conhecida como Teoria de Primeira Ordem ou Teoria de Deformação por Corte. Conclui expondo que uma viga em que os esforços cisalhantes são contabilizados (deformação de corte) chama-se de Timoshenko, em razão da Teoria de Vigas de Timoshenko.

No painel sanduíche as camadas encontram-se ligadas por um adesivo que transfere os esforços entre os componentes faces e núcleo, a rigidez à flexão aumenta com a espessura do núcleo, similarmente o que ocorre com uma viga, a rigidez aumenta com a distância entre os banzos (ALMEIDA, 2009).

Segundo Nogueira de Ó (2009) a modelagem de uma viga sanduíche na flexão exige algumas propriedades e a primeira delas é a Rigidez à Flexão. No caso da viga isotrópica, o produto do Módulo de Elasticidade pelo Segundo Momento de Inércia define a rigidez da viga sanduíche e o momento de inércia varia de acordo com a espessura, assim se torna um fator muito importante na rigidez à flexão. Podem-se obter valores ideais dessa propriedade com materiais inferiores em Módulos de Elasticidade desde que se adapte a espessura gerando o efeito sanduíche, conforme (PETRAS, 1998) citado na seção 2.4.2 deste trabalho.

\section{- $\quad$ Falhas em vigas Sanduíche}

O comportamento dos materiais no regime elástico que compõem a viga sanduíche é um aspecto importante de análise para as falhas deste tipo de estrutura, bem como os parâmetros de projeto que os caracterizam. Não menos importante, o tipo de carregamento e a localização configurando o estado de tensão sobre a estrutura, podem caracterizar o modo de falha (NOGUEIRA DE Ó, 2009).

O autor apresenta diferentes modos de falha, incluindo os efeitos tridimensionais, afirma que uma análise exaustiva das tensões e aplicações em regiões críticas deve ser conduzida. A análise torna-se difícil devido a interação entre os vários modos de falha e ao comportamento complexo não linear e não elástico dos materiais. Um determinado modo de falha pode ativar ou interagir com outro tipo de falha compondo outra distinta ao do início do carregamento, modificando as características de comportamento até a ruptura.

Conforme apontado na seção 2.4.6 (Quadro 8) deste trabalho, a Norma ASTM 393/393-2011 orienta e reporta alguns códigos de falhas que devem ser observados. Segundo (NOGUEIRA DE Ó, 2009) no início conduzir uma análise de falha torna-se difícil e 
complexo, porém com a prática é possível tirar algumas conclusões sobre a estrutura conforme experiência adquirida (AMERICAM SOCIETY FOR TESTING AND MATERIALS, 2011).

\section{- Modos de falhas mecânicas dos painéis sanduíche}

Os modos de ruptura dos painéis sanduíche dependem das características de cada um de seus componentes, faces, núcleo e da adesão entre eles, são determinantes no modo de ruptura dos painéis e podem ser observadas de várias maneiras como segue: (i) ruptura das faces devido aos esforços; (ii) ruptura por cisalhamento do núcleo e (iii) ruptura nos apoios (FERREIRA, 2012).

Almeida (2009) descreve diversos modos de ruptura que podem limitar e condicionar a resistência do painel sanduíche. A capacidade de carga depende do material empregado nas faces e núcleo e da aderência entre eles; das dimensões do painel como espessura e largura, geometria das faces e núcleo e a geometria da estrutura em si são fatores que podem influenciar diretamente seu desempenho. Acrescenta que o conhecimento das propriedades dos materiais constituintes do núcleo e faces e o processo de fabricação também são determinantes. Entre os vários modos de ruptura o autor apresenta os seguintes: (i) por tração das faces; (ii) por instabilidade local das faces devido a esforços de compressão; (iii) cisalhamento do núcleo ou do adesivo entre eles; (iv) esmagamento da face e/ou núcleo na posição do apoio e (v) nas zonas de ligação por tração, compressão ou cisalhamento.

As considerações e as análises apresentadas pelos pesquisadores sobre o comportamento mecânico e falhas do painel sanduíche se mostraram similares, desta forma, a revisão se presta como base para com os testes mecânicos futuros auxiliar dentro das possibilidades na análise de falhas dos painéis sanduíches produzidos com núcleos de subprodutos da agroindústria.

\subsubsection{Análises estatísticas}

Uma das maneiras de validar um experimento científico é utilizando-se da análise estatística. Obter conclusões válidas para a população de amostras pode certificar a autenticidade do trabalho científico. A palavra população é normalmente definida como um conjunto de indivíduos com certas características, amostra representa uma parte desta 
população e matematicamente população é um conjunto e amostra um subconjunto (CANTERI et.al, 2001).

$\mathrm{Na}$ análise estatística, algumas informações são avaliadas (medidas-resumo) e convenientemente utilizadas para resumir a variabilidade de um conjunto de dados. Os autores acrescentam a conveniência das medidas que sumarizam a variabilidade do grupo de informações observadas e que permite analisar conjuntos diferentes de resultados, segundo algum critério estabelecido. Alguns critérios utilizados como os que medem a dispersão de dados sobre a média são: (i) desvio padrão e (ii) coeficiente de variação. O princípio básico é avaliar os desvios e variâncias em relação aos dados observados, tanto um quanto o outro são medidas de dispersão calculadas sobre a média das observações (MORETTIN; BUSSAB, 2004).

O coeficiente de variação $(\mathrm{CV})$ pode ser uma maneira de estimar a precisão dos resultados em experimentos científicos que possuem a mesma resposta medida (MUNIZ; JUDICE; CAVALHEIRO, 1999).

Segundo Lana et al. (2006) o coeficiente de variação pode avaliar as respostas dos experimentos, pois, é definido pela relação entre o desvio-padrão (s) e a média aritmética $(\bar{x})$ e depende mais do desvio-padrão do que da média.

Ainda segundo Muniz, Judice e Carvalheiro (1999), o (CV) representa o desvio padrão medido como porcentagem da média. Acrescenta (SCHMILDT et al., 2017) que o (CV) mede a variabilidade dos resultados experimentais, sendo útil na confirmação do número de ensaios, pode detectar uma diferença entre médias de tratamentos com uma dada probabilidade, entendido que o $(\mathrm{CV})$ está estritamente relacionado ao erro residual nas análises de variâncias.

Assim fica evidente a importância do estudo do (CV) em experimentos científicos, pois muitas pesquisas comparam seus resultados aos sugeridos por Gomes (1990), o autor estabelece uma classificação por faixas, onde os coeficientes de variação são baixos quando inferiores a 10\% (homogeneidade nas amostras), médios entre 10 e 20\% (média homogeneidade) e altos entre 20 e 30 \% (amostras heterogêneas) (SILVA et al., 2008).

Complementando a análise, a estatística inferencial fundamenta-se na teoria das probabilidades e se preocupa com a análise dos dados e sua interpretação (GUEDES et al., 2008). A estatística inferencial se apoia em testes de hipóteses, utiliza da estimação para fazer 
comparações e predições, é uma suposição numérica cercada de parâmetros, o nível de significância mais usado é de 5\% (RODRIGUES; LIMA; BARBOSA, 2017).

Segundo Souza (2002) o objetivo da variância é analisar diferenças entre as médias aritméticas das amostras, desde que os grupos que geram as médias sejam escolhidos aleatoriamente. Dessa forma é possível analisar a variância entre as amostras considerando que o pesquisador pré-determine as variáveis, assim concluir se entre as médias existem diferenças estatisticamente significativas ou não.

\subsubsection{Painéis aglomerados de partículas revestidos com placas de fibrocimento:} uso de subprodutos da agroindústria

A revisão bibliográfica deste trabalho e especialmente representada pela seção 2.4 em seu conteúdo proporcionou a possibilidade de se pensar em produzir um modelo de painel sanduíche com núcleo e faces similares aos existentes no mercado, embasado na quantidade variada de tipos de painéis existentes. Este trabalho almeja o desenvolvimento de um novo compósito, associar materiais empregados em sistemas construtivos comercializados no mercado da construção civil com outros materiais não convencionais como o caso dos subprodutos da agroindústria.

Conforme vários autores citados na seção 2.2.4 e 2.2.5 deste trabalho, os painéis de partículas de madeira com substituição parcial por outras fibras vegetais e características físico-mecânicas descritas, associadas a placas de fibrocimento podem compor uma estrutura sanduíche conforme (NOGUEIRA DE Ó, 2009) descreve:

Uma estrutura sanduiche é sempre constituída por três elementos base, as duas faces e o núcleo, sendo estes elementos unidos por um adesivo. As faces são as camadas externas e têm pouca espessura, encontrando-se separadas por um núcleo, que forma a camada intermédia, sendo este sempre o elemento de maior espessura no sanduiche. As faces são geralmente fabricadas em materiais de alta resistência (aços, compósitos fibrosos), enquanto que no núcleo normalmente são utilizados materiais com baixo peso específico (madeira balsa, espumas poliméricas, papel kraft em favo de abelha, etc.). 
Sabendo da importância da industrialização da construção civil e seguindo uma das linhas de pesquisa do Programa de Pós-graduação em Engenharia e Ciências de Materiais, Faculdade de Zootecnia e Engenharia de Alimentos da Universidade de São Paulo que desenvolve, caracteriza e aplica novos materiais voltados à agroindústria, o produto desta pesquisa apresenta um caráter inovador, produzido em condições laboratoriais tenta se aproximar timidamente às condições dos processos de produção industrial, foi caracterizado e comparado a produtos existentes no mercado.

Pesquisas que avaliaram painéis sanduíches compostos por núcleos de materiais variados e estudos futuros que analisem as propriedades dos painéis com núcleos formados por subprodutos da agroindústria pode proporcionar um avanço científico e auxiliar no entendimento do comportamento mecânico do compósito.

Assim os painéis sanduíches propostos associaram placas de fibrocimento com painéis de partículas de fibra da casca de coco verde, Coco nucifera e maravalha de Pinus sp., e se possível em estudos futuros propor a utilização do painel como componente ou elemento de um sistema construtivo de vedação vertical. 


\section{MATERIAIS E MÉTODOS}

Para contemplar os objetivos deste trabalho, este capítulo apresenta a descrição da metodologia utilizada no desenvolvimento dessa pesquisa resumida na (Figura 30). Descrevem-se os materiais, parâmetros, métodos e procedimentos para a produção do painel sanduíche, o qual foi composto por painéis aglomerado de partículas homogêneas de subprodutos da agroindústria e painel MDP comercial. O texto detalha a produção dos painéis aglomerado homogêneos (painéis híbridos) compostos por partículas de madeira pinus, Pinus sp, com substituição parcial das partículas de madeira por fibra da casca de coco verde, Cocos nucifera, adensado com resina poliuretana bi componente à base de óleo de mamona, também apresenta os critérios para a aquisição, recebimento e caracterização da placa de fibrocimento que foi escolhida como revestimento dos painéis sanduíche. Relata a preparação dos corpos de prova de todos os componentes construtivos e dos painéis sanduíche propriamente dito para os ensaios de caracterização física, mecânica e térmica. Finalmente expõe o planejamento e experimento estatísticos utilizados para analisar os resultados dos ensaios propostos.

Figura 30 - Fluxograma das atividades desenvolvidas no trabalho de pesquisa

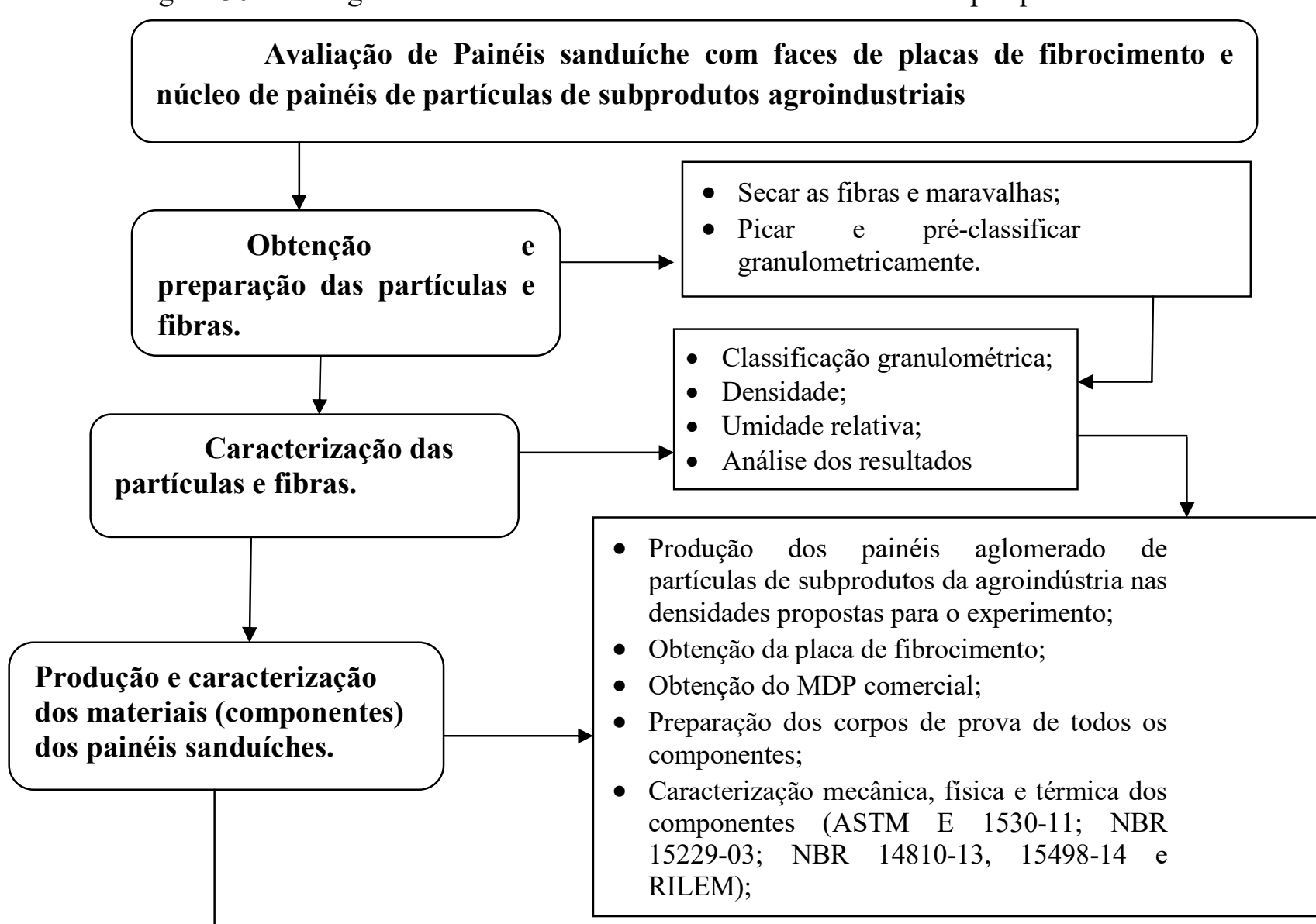


- MOR; MOE; LOP; Adesão Interna (TP); Arranque de parafuso (topo e superficial) (AP) e Energia específica (EE);

- Densidade aparente (D), Densidade aparente saturada (DA), densidade aparente seca (DS) inchamento da espessura (I), teor de umidade (U), absorção de água (AA) e Porosidade aparente (PA).

- Condutividade e resistência térmica;

- Planejamento estatístico experimental e análise dos resultados.

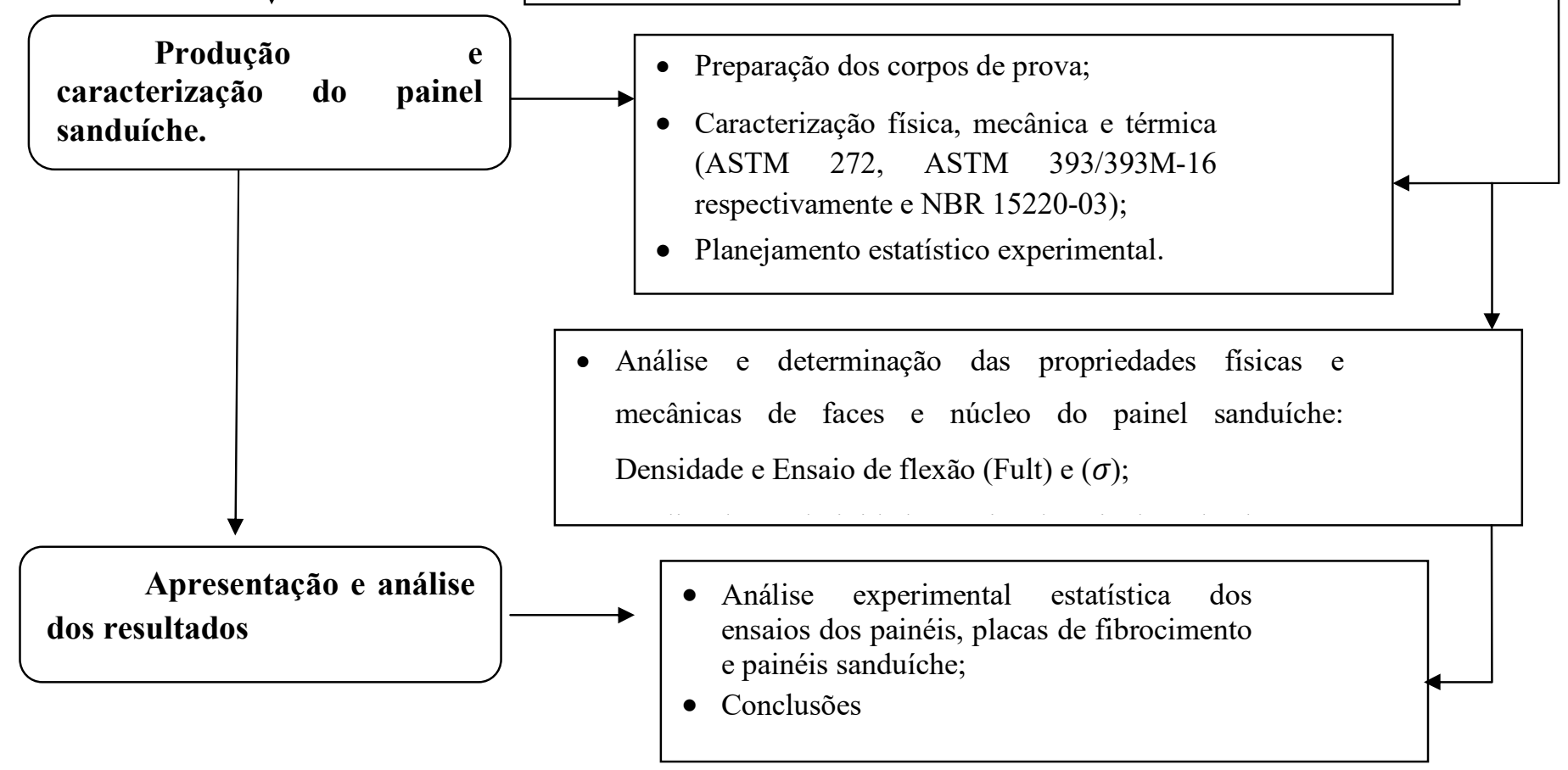

Fonte: Próprio autor.

\subsection{Materiais}

\subsubsection{Painéis de partículas aglomerados de subprodutos da agroindústria}

Os painéis híbridos foram compostos por dois subprodutos da agroindústria. A fibra da casca de coco verde, Cocos nucifera, foi fornecida por uma indústria de reciclagem de resíduos sólidos, instalada no município de Holambra, São Paulo. As partículas de madeira de Pinus sp., nomeadas do tipo maravalha conforme classificação dos subprodutos da indústria de transformação da madeira (FIORELLI et al., 2015), foram adquiridas na Faculdade de Zootecnia e Engenharia de Alimentos da Universidade de São Paulo, no município de Pirassununga, São Paulo, subproduto utilizado no manejo de aves. 
O adesivo para a produção dos painéis de partículas homogêneas de subprodutos da agroindústria e dos painéis sanduíche é uma resina orgânica bi componente poliuretana à base de óleo de mamona. Composta por dois componentes, um derivado vegetal e um isocianato aromático são misturados na proporção 1:1. O derivado vegetal é um poliol para obtenção de

poliuretanas, com aspecto líquido e coloração amarelado tem densidade entre $1,0 \mathrm{~g} / \mathrm{cm}^{3}$ e 1,2 $\mathrm{g} / \mathrm{cm}^{3}$; o isocianato di ou polifuncional é um pré-polimero derivado do petróleo, com aspecto líquido e coloração marrom escuro tem densidade próxima a $1,24 \mathrm{~g} / \mathrm{cm}^{3}$.

$\mathrm{O}$ adesivo utilizado para o ensaio de tração perpendicular foi o etil cianoacrilato, adquirido no comércio local da cidade de Pirassununga, São Paulo, do fabricante ATB Indústria e Comercio de Adesivos S.A - TekBond, instalada na cidade de Embu, São Paulo.

Os parafusos para os ensaios de arranque seguem os requisitos da norma ABNT NBR 14810-2: 2013 - Painéis de partículas de média densidade: Requisitos e métodos de ensaio, adquiridos no comércio local da cidade de Pirassununga, São Paulo.

\subsubsection{Painel de partículas aglomerado constituído de madeira}

O painel escolhido e classificado como MDP comercial, conforme ABNT NBR 14.810-2: 2013 - Painéis de partículas de média densidade: Requisitos e métodos de ensaio, foi adquirido no comercio regional de Pirassununga, na cidade de Campinas, São Paulo. A espessura média aproximada do painel de partículas é de $15 \mathrm{~mm}$, seguindo a dimensão descrita no delineamento experimental deste trabalho para que o sanduíche formado se aproxime das dimensões comerciais pesquisadas. $\mathrm{O}$ adesivo utilizado para o ensaio de tração perpendicular e os parafusos para os ensaios de arranque foram descritos no item 3.1.1.

\subsubsection{Placas de fibrocimento}

Primeiramente foi realizada uma pesquisa de mercado dos principais fabricantes regionais de placas de fibrocimento, a finalidade foi obter informações necessárias para a escolha da empresa que melhor atenderia nossas expectativas. $\mathrm{O}$ uso de materiais não convencionais como reforço estrutural na matriz cimentícia e/ou matérias primas de baixo impacto em seu processo de produção, foram os principais parâmetros utilizados para a escolha dos fornecedores. Assim a placa de fibrocimento que revestiu os painéis de partículas 
homogêneas foi adquirida no comércio regional de Pirassununga, do Fabricante Infibra, instalado na cidade de Leme, São Paulo. A placa escolhida recebe a classificação tipo B conforme Norma ABNT NBR 15.498:2014-Placas de fibrocimento sem amianto, indicadas para uso interno e aplicações externas não sujeitas à ação direta de sol, chuva, calor e umidade.

\subsubsection{Painéis sanduíche}

A produção do painel sanduíche ocorreu da associação da placa de fibrocimento aos painéis de partículas aglomerados de subprodutos da agroindústria (painéis de partículas de madeira pinus, Pinus sp, com substituição parcial por fibra da casca de coco verde, Cocos nucifera) e ao painel comercial MDP. Os painéis produzidos são compostos por faces e núcleo, placa de fibrocimento e painéis de partículas homogêneas respectivamente. Todo o processo decorreu nas dependências da Faculdade de Zootecnia e Engenharia de Alimentos de Pirassununga - FZEA/USP.

A resina orgânica bi componente poliuretana à base de óleo de mamona compôs o conjunto placa de fibrocimento, painéis de partículas aglomeradas. A resina passou previamente por testes feitos em laboratório para que atendesse os parâmetros de processo de produção do painel sanduíche.

\subsubsection{Equipamentos}

No processo de preparação das matérias primas que previamente foram secas (previamente secas conforme descrito no item 3.2.2) e picadas se utilizaram os seguintes equipamentos: (i) moinho de facas (desintegrador e picador de forragens) modelo DPC-1, fabricante Cremasco com tela de malha com dimensões aproximadas de $8 \mathrm{~mm}$ de diâmetro (Figura 35), e (ii) estufa modelo MA035, fabricante Marconi (Figura 39).

Para caracterização física das matérias primas se utilizaram os seguintes instrumentos de medição: (i) balança eletrônica digital analítica, da marca Shimadzu, modelo AY-220, com precisão igual a quatro casas decimais (0,0001g) (Figura 36); (ii) estufa com circulação de ar, marca Nova Etica, modelo 400/5ND (Figura 37) e (iii) multipicnômetro de 
gás hélio, marca Quantachrome Ultrapycnometer 100 e modelo MVP5DC, com porta amostra de volume igual a $56,56 \mathrm{~cm}^{3}$ (Figura 38 ).

Para o processo de produção dos painéis de partículas homogêneas de subprodutos da agroindústria utilizaram-se os equipamentos como segue: (i) agitador do fabricante Marconi (Figura 40) com peneiras variando entre $8 \mathrm{~mm}$ e $0,3 \mathrm{~mm}$; (ii) prensa termohidráulica fabricante Hidral-Mac, com capacidade de prensagem de 100 toneladas, controle de temperatura de $100^{\circ} \mathrm{C}$ e pressão de $5 \mathrm{MPa}$ (Figura 41) e (iii) misturador planetário modelo LA20, fabricante Amadio (Figura 41).

Para a preparação dos corpos de prova utilizaram-se: (i) serra elétrica de bancada (Figura 42), fabricante Makita (ii) serra elétrica de bancada com disco diamantado para materiais cimentícios, fabricante Peres de Oliveira (Figura 49).

Nas caracterizações físicas dos painéis de partículas, da placa de fibrocimento e dos painéis sanduíches ocuparam-se os seguintes equipamentos: (i) câmara climática, modelo SL 206, fabricante Solab (Figura 43); (ii) balança eletrônica digital analítica, da marca Shimadzu, modelo AY-220, com precisão igual a quatro casas decimais (0,0001g) (Figura 36); (iii) paquímetro Mitutoyo modelo CD-8" CX-B (Figura 35b); (iv) recipiente com água destilada; (v) papel absorvente e (vi) estufa com circulação de ar, marca Nova Etica, modelo 400/5ND (Figura 37).

Para as caracterizações mecânicas dos painéis de partículas, da placa de fibrocimento e dos painéis sanduíches foram: (i) câmara climática, modelo SL 206, fabricante Solab (Figura 43); (ii) máquina universal de ensaios mecânicos da marca EMIC, modelo DL 30.000, com capacidade de 30 toneladas e controle de velocidade do atuador e célula de carga com capacidade de 5KN (Figura 45); (iii) paquímetro Mitutoyo modelo CD-8” CX-B (Figura 35b) e (iv) computador com software Tesc versão 1.3 interligado (unidade de aquisição de dados) com a máquina universal (Figura 45).

Para a análise da condutividade térmica dos painéis de partículas e da placa de fibrocimento utilizaram-se: (i) paquímetro Mitutoyo modelo CD-8" CX-B (Figura 35b); (ii) pasta térmica e (iii) equipamento Thermal Conductivity Tester DTC-300, modelo 2022, marca Discovery (Figura 49). 


\subsection{Métodos}

O diagrama seguinte resume o processo metodológico desenvolvido para o estudo do painel sanduíche (Figura 31):

Figura 31 - Fluxograma das atividades desenvolvidas para o estudo do painel sanduíche.

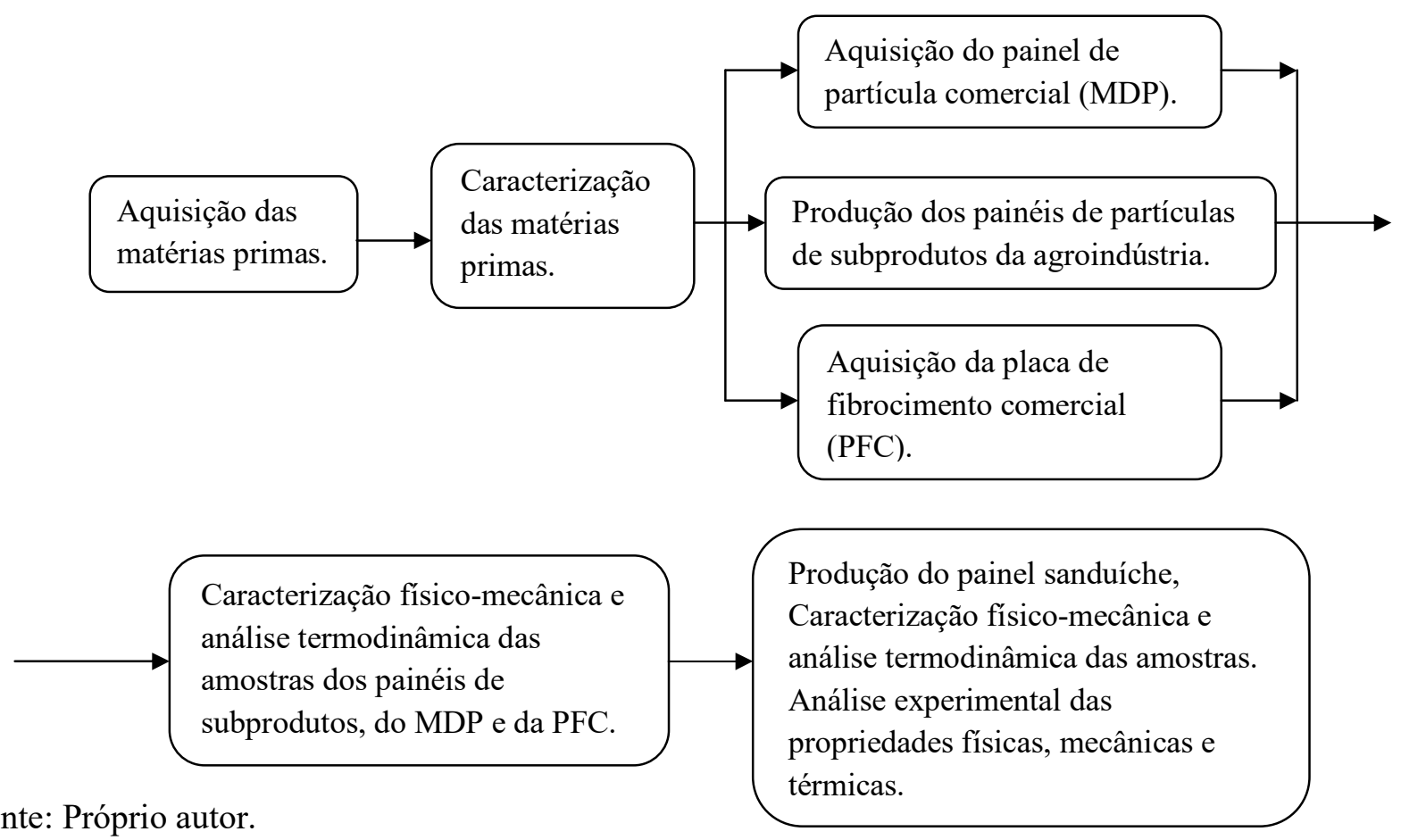

\subsubsection{Caracterização dos materiais: partículas e fibras de subprodutos da} agroindústria

A caracterização das matérias primas, fibra da casca de coco verde, Cocos nucifera, e partículas de madeira, Pinus sp., determina algumas propriedades conforme exposto no item 2.2.5 e demonstra que o material selecionado possui as qualidades necessárias para a produção dos painéis de partículas. Como as matérias primas variam em função de sua natureza orgânica este item torna-se muito importante. Segundo (FIORELLI, 2013) a definição do tamanho e tipo de partícula é o inicio do processo tecnológico de produção de painéis, pois influência diretamente nas propriedades físico-mecânicas. 
Antes da realização dos ensaios físicos, as fibras e as partículas foram previamente secas conforme descrito no item 3.2.2, picadas em moinho de facas (desintegrador e picador de forragens) e passadas por uma tela de malha com dimensões aproximadas de $8 \mathrm{~mm}$ de diâmetro (Figura 32a e 32b) para uma classificação preliminar, similarmente aos procedimentos descritos por (SARTORI, 2012).

Figura 32 - Picador com malha para classificação primária das matérias primas
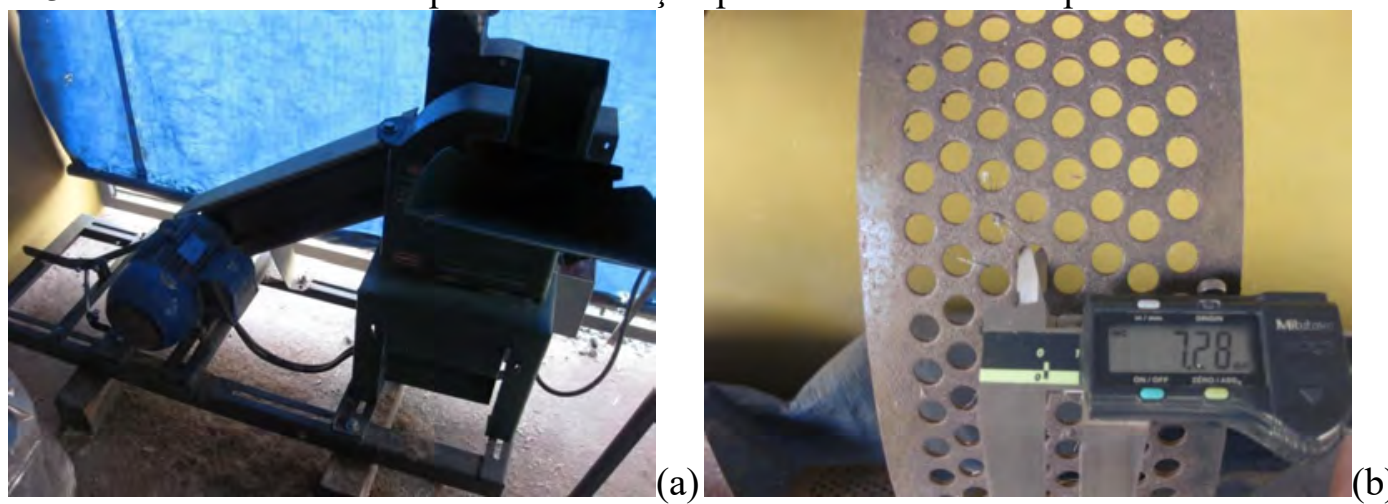

(a) Picador e (b) Malha de classificação Fonte: Própria autoria.

\subsubsection{Teor de umidade das partículas e fibras}

Após previamente tratadas e classificadas conforme descrito no item 3.2.2 as amostras foram pesadas e os valores registrados como massa úmida. Posteriormente foram acondicionadas em estufa com circulação de ar por 24h a uma temperatura média de (103 \pm 2 ${ }^{\circ} \mathrm{C}$ ) onde obtiveram massa constante (Figura 33) e foram pesadas em balança eletrônica digital analítica (Figura 34) registrando os resultados como massa seca.

Figura 33 - Estufa com circulação de ar para a preparação das matérias primas

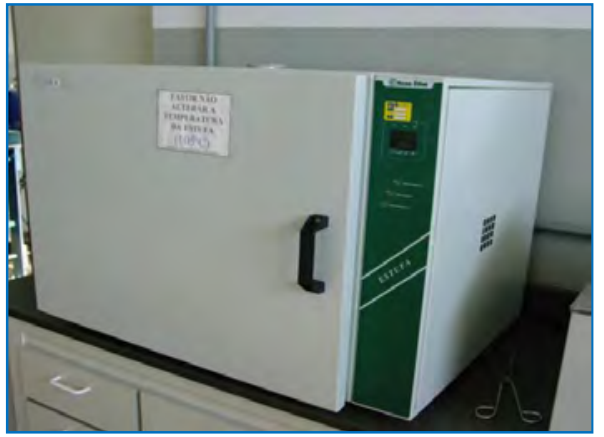

Fonte: Própria autoria. 
Foram feitas medições que não diferiram em $0,1 \%$ em um intervalo mínimo de 6 horas. Os procedimentos descritos seguem as prescrições da norma NBR 14.810-2: 2013Painéis de partículas de média densidade: Requisitos e métodos de ensaio e conforme trabalhos publicados (GOMES et al., 2013). O valor de teor de umidade (U) foi determinado pela equação (1):

$$
U=\frac{M u-M s}{M s} * 100(1)
$$

Onde:

$\mathrm{U}=$ Teor de umidade do $\mathrm{CP}$, expresso em porcentagem (\%);

$\mathrm{Mu}=$ Massa úmida do $\mathrm{CP}$; expressa em gramas (g);

Ms = Massa seca do CP, expressa em gramas $(\mathrm{g})$;

O resultado é a média das medições de cada corpo de prova analisado, expresso em porcentagem (\%), com precisão de $0,1 \%$.

Figura 34 - Balança eletrônica digital com amostra de fibra de coco verde

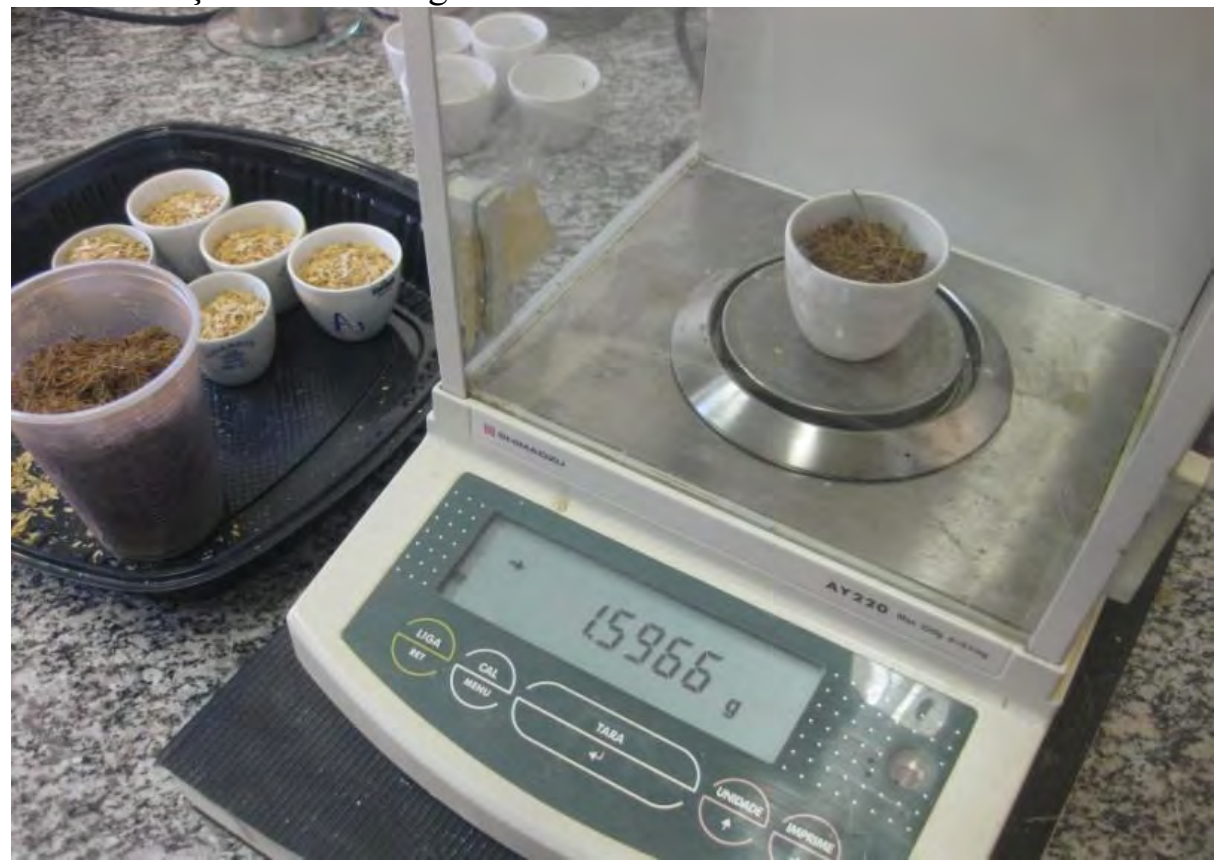

Fonte: Própria autoria. 


\subsubsection{Densidade real das partículas e fibras}

Inicialmente as partículas foram tratadas conforme descrito no item 3.2.1.1 e posteriormente pesadas em balança eletrônica digital analítica (Figura 34).

As densidades foram determinadas utilizando um multipicnômetro de gás hélio. $\mathrm{O}$ equipamento foi calibrado assim que as amostras foram inseridas dentro do aparelho, a chave de pressão é aberta até uma pressão de $117,2 \mathrm{KPa}$, momento em que a chave é fechada conforme orientação do fabricante. O volume é determinado por comparação de pressões, em cada medição um volume de referência é preenchido no aparelho e registrado sua pressão antes do preenchimento do porta-amostra, posteriormente as amostras receberam pressões que foram registradas em sequência a pressão de referência (Figura 35).

Figura 35 - Aparelho Multipicnômetro com amostra de maravalha da madeira de pinus

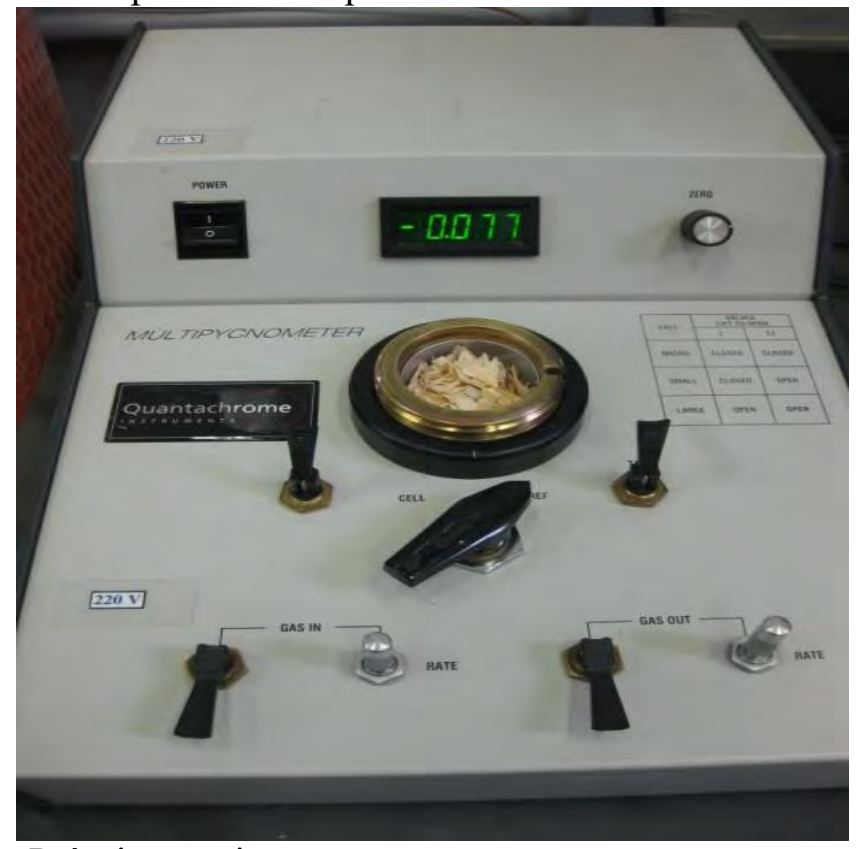

Fonte: Própria autoria.

Para o cálculo da densidade real o porta-amostra com fibras e partículas foram pesados em balança eletrônica digital analítica e inseridos no equipamento. Dentro do aparelho as amostras foram submetidas a pressões, uma medida na câmara com amostra e outra medida na câmara de volume de referência, como o gás hélio penetra nos vazios da amostra é possível determinar o volume real. Da razão entre as massas aferidas, pelos 
volumes reais determinados com o multipicnômetro, foi calculada a densidade média real de cada matéria prima.

Foram realizadas dez medições de cada amostra, com os resultados obtidos pelo aparelho e utilizando planilha eletrônica obteve-se o volume e densidade média real das amostras conforme equações (2) e (3).

$$
\begin{gathered}
V p=V c-V r\left[\left(\frac{P 1}{P 2}\right)-1\right](2) \\
\rho=\frac{m}{v}(3)
\end{gathered}
$$

Onde:

$\mathrm{Vp}=$ volume da amostra expresso em $\left(\mathrm{cm}^{3}\right)$

$\mathrm{Vc}=$ volume do porta amostra expresso em $\left(\mathrm{cm}^{3}\right)$;

$\mathrm{Vr}=$ volume de referência expresso em $\left(\mathrm{cm}^{3}\right)$;

P1 = pressão aferida após a pressurização do volume de referência expressa em (PSI);

P2 = pressão aferida após a inclusão de Vc no multipicnômetro expressa em (PSI).

$\rho=$ densidade real da amostra expressa em $\left(\mathrm{g} / \mathrm{cm}^{3}\right)$;

$\mathrm{m}=$ massa da amostra expressa em $(\mathrm{g})$;

$\mathrm{v}=$ volume da amostra expressa em $\left(\mathrm{cm}^{3}\right)$.

\subsubsection{Processo de produção dos painéis de partículas aglomerados de subprodutos da agroindústria}

Iniciou-se o processo de produção com a obtenção das materiais primas, seu tratamento e caracterização. As partículas de madeira e as fibras da casca de coco verde foram condicionadas em bandejas metálicas e levadas à estufa com circulação de ar (Figura 36a e $36 \mathrm{~b}$ ), a uma temperatura de $60^{\circ} \mathrm{C}$ por 36 horas, com a finalidade de reduzir o teor de umidade entre o intervalo de $5 \%$ a $13 \%$, procedimento que retira a umidade impregnada nas partículas e evita a expansão dos painéis durante o processo de produção (CRAVO, 2013). 
Figura 36 - Estufa para secagem das partículas de madeira pinus e fibras de coco verde
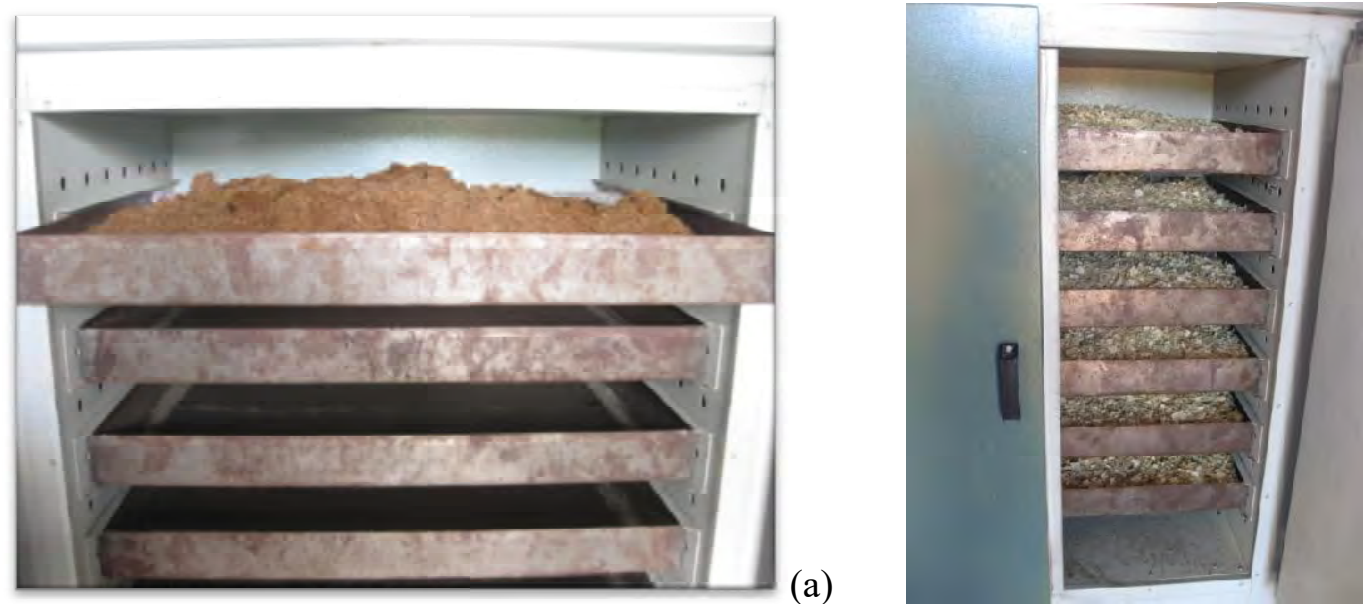

(b)

(a) Bandejas com fibra da casca de coco verde e (b) Bandejas com partículas de madeira Fonte: Própria autoria.

Secas, as fibras da casca de coco verde e as partículas de madeira foram processadas em moinho de facas (desintegrador e picador de forragens) (Figura 32a) com a finalidade de se obter uma granulometria aproximada ao desejado, durante o processamento no moinho de facas as partículas passaram por uma peneira com abertura aproximada de $8 \mathrm{~mm}$ de diâmetro (Figura 32b). Posteriormente as fibras da casca de coco verde foram depositadas em um agitador (Figura 37a) e classificadas em peneiras de abertura entre 1,0 e 4,0 mm, utilizando as fibras retidas na peneira de 1,0 $\mathrm{mm}$ (figura $37 \mathrm{~b}$ ). As partículas de madeira foram classificadas com peneiras de abertura entre 2,0 e $8,0 \mathrm{~mm}$ sendo utilizadas aquelas retidas na peneira de 2,0 $\mathrm{mm}$ e 4,0 mm (Figura 37c e 37d), a escolha deste intervalo pautou-se em estudos de (PASSOS, 2005; BONILLA BUENO, 2015; BRITO et al., 2006) onde utilizaram dimensões similares associadas à fibra da casca de coco verde e partículas de madeira.

As dimensões das partículas e fibras, as proporções de massa de fibras da casca de coco verde e partículas de madeira da espécie pinus, a porcentagem de resina e os parâmetros e variáveis de produção dos painéis aglomerado de partículas homogêneas de subprodutos da agroindústria foram determinadas com base nos trabalhos de (PASSOS 2005; BRITO et al., 2006; CRAVO, 2013; SARTORI, 2012; BONILLA BUENO, 2015; FIORELLI et al., 2015). 
Figura 37 - Conjunto de peneiras sobre agitador para classificação granulométrica das matérias primas

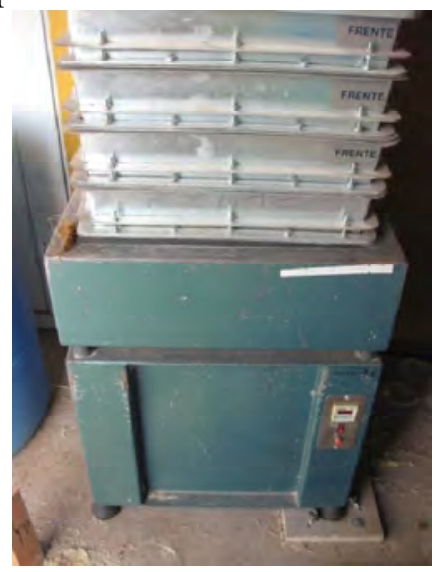

(a)
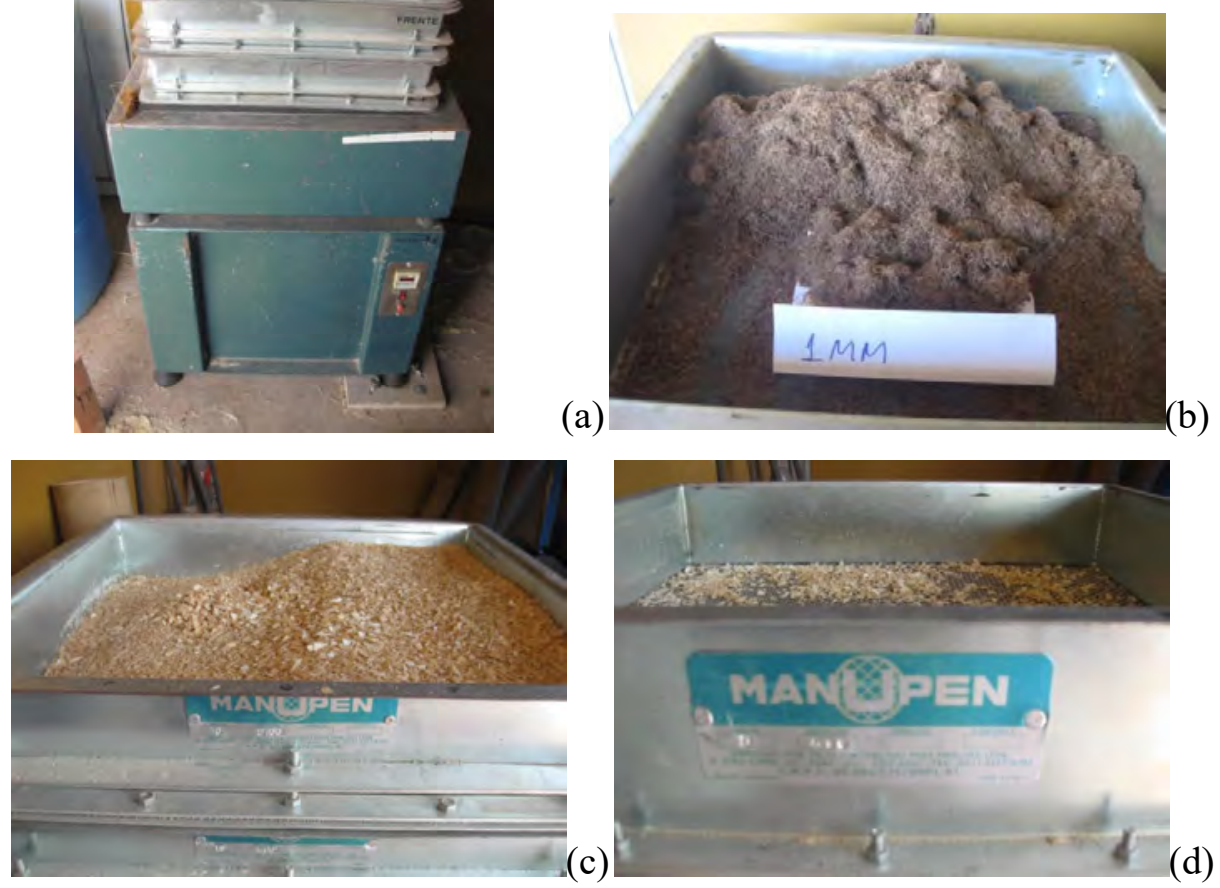

(a) Agitador com conjunto de peneira (b) Fibra retida na peneira de $1 \mathrm{~mm}$ (c) Partículas retidas na peneira de $2 \mathrm{~mm}$ (d) Partículas retidas na peneira de $4 \mathrm{~mm}$

Fonte: Própria autoria.

Estabelecidas as densidades médias experimentais dos painéis (Quadro 9), foram calculadas as quantidades de massa dos subprodutos da agroindústria necessária para a composição dos painéis experimentais. Para determinar a quantidade de matéria-prima a ser utilizada, nomearam-se os lados (L1 e L2) e a espessura (e), considerando os parâmetros de medidas iguais a $400 \mathrm{~mm}$ x $400 \mathrm{~mm}$ (medidas laterais da forma) x $15 \mathrm{~mm}$ (espessura do painel) dimensionou-se o volume do painel aglomerado. O cálculo da quantidade de massa apresenta-se a seguir: (i) diante das dimensões dos painéis a serem produzidos (400 mm x 400 $\mathrm{mm} \times 15 \mathrm{~mm}$ ) calculou-se os volumes (v) para todas as densidades estabelecidas no delineamento experimental; (ii) com o cálculo do volume aplicou-se a equação (4) encontrando a quantidade de massa de matéria-prima seca para cada densidade (CRAVO, 2013). 


$$
D=\frac{m}{v}(4)
$$

Onde:

$\mathrm{V}=\mathrm{L} 1 \times \mathrm{L} 2 \mathrm{x}$ e, volume estabelecido do painel expresso $\mathrm{em}^{3}$;

$\mathrm{D}=$ densidade estabelecida do painel expressa em $\mathrm{g} / \mathrm{cm}^{3}$;

$\mathrm{m}=$ massa a ser determinada expressa em $\mathrm{g}$;

Com o volume, a densidade e a massa total estabelecida como descrito anteriormente, determinou-se a quantidade total de massa com resina (X) e parcial de massa seca de cada matéria prima (m) aplicando a equação (5). Para a determinação da massa proporcional de $70 \%$ de partícula de madeira e $30 \%$ de fibra da casca de coco verde multiplicou-se pelas respectivas porcentagens.

$$
X+0,15 X=m(5)
$$

Onde:

$X=70 \%$ de massa seca de partículas de madeira somado $30 \%$ de massa seca de fibra da casca de coco verde;

$$
\begin{aligned}
& 0,15 \mathrm{X}=15 \% \text { de resina da massa seca total }(70 \%+30 \%) \\
& \mathrm{m}=\text { massa a ser determinada expressa em } \mathrm{g} .
\end{aligned}
$$

Posteriormente ao cálculo da quantidade de matéria-prima, as partículas foram pesadas em balança eletrônica digital analítica e em seguida adicionou-se a resina PUmamona composta por duas fases (são misturados na proporção 1:1) em uma proporção de $15 \%$ do peso da massa seca do material, quantidade necessária para a produção do painel de partículas de madeira e da fibra da casca do coco verde (Figura 38a). Visando melhorar a uniformidade da mistura, as partículas e fibras já com prévia uniformização, foram introduzidas em um misturador planetário (Figura 38b).

Após o tempo de mistura de 10 minutos, as partículas homogeneizadas foram depositadas em um molde formador de painel compondo um "colchão" de partículas e fibras (Figura 38c), a forma (“colchão" pré-prensado com dimensões aproximada de $400 \mathrm{~mm}$ x 40 $\mathrm{mm}$ ) foi posteriormente transferida para uma prensa termo-hidráulica (Figura 38d), onde controlada a uma temperatura de $100^{\circ} \mathrm{C}$, pressão de $5 \mathrm{MPa}$ e tempo de aplicação de carga de 
10 minutos produziram-se os painéis, a espessura foi limitada entre os pratos da prensa por um espaçador de aço (barra quadrada de $15 \mathrm{~mm}$ ).

Ao término do processo de prensagem, os painéis devem ser estocados em condições locais livre de umidade e em temperatura ambiente (Figura 38e), período em que ocorre a continuação do processo de cura da resina (FIORELLI, 2013).

Figura 38 - Etapas de processamento para a fabricação dos painéis aglomerado de subprodutos da agroindústria

(a)

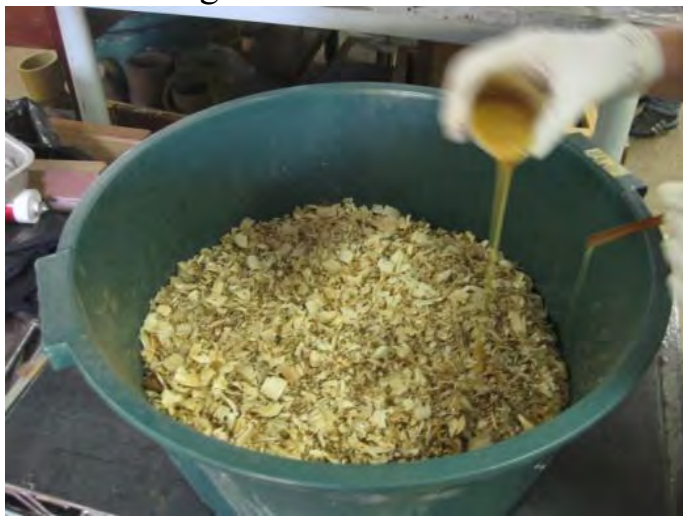

(c)

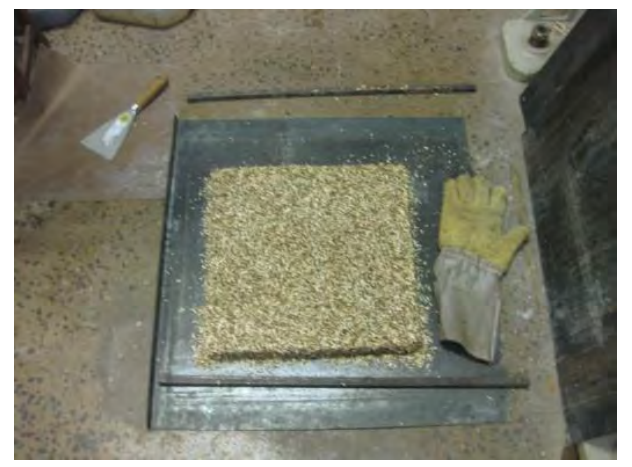

(e)

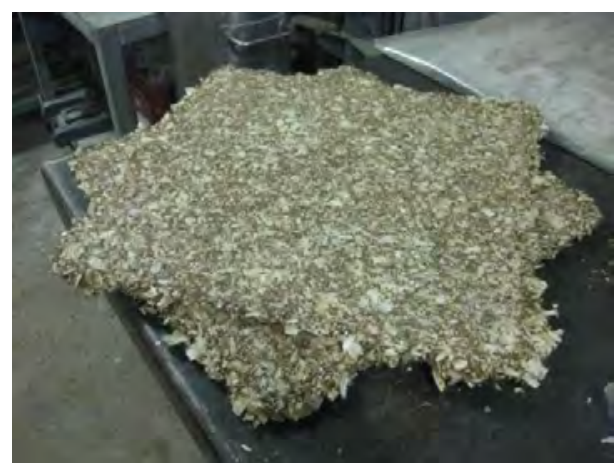

(b)
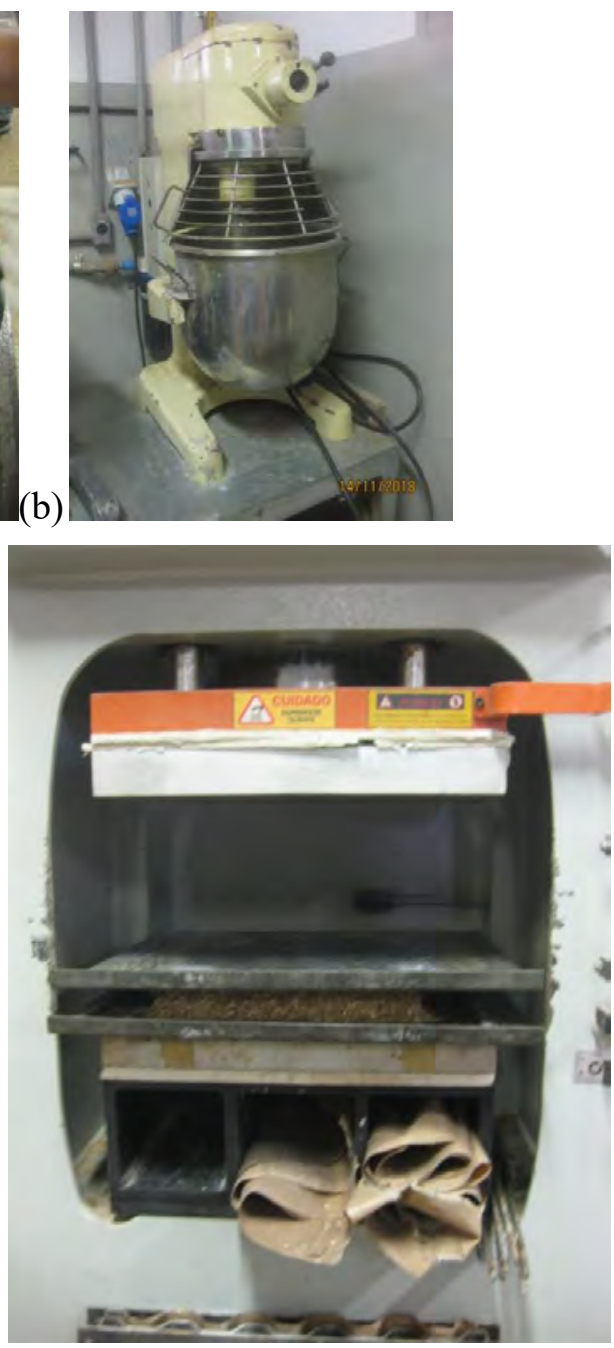

(d)

(a) Aplicação da resina (b) Misturador planetário (c) Colchão de partículas e fibras (d) Colchão na prensa hidráulica (e) Painel aglomerado Fonte: Própria autoria. 
A espessura de $15 \mathrm{~mm}$ dos painéis de partículas foi proposta de maneira que associado (sobreposto) a outro painel pudessem compor dimensões aproximadas ao núcleo de painéis sanduíche comerciais. Diante disso e fundamentado na pesquisa de mercado o núcleo do painel sanduíche (painéis de partículas aglomeradas de subprodutos da agroindústria) deste estudo foi estabelecido em aproximadamente $30 \mathrm{~mm}$, o processo de produção dos painéis de partículas se encontra no item 3.2.2.

O delineamento experimental propôs investigar as características físico-mecânicas e térmicas dos painéis de partículas e adotou as proporções em massa seca de matéria-prima em $70 \%$ para partículas de madeira e 30\% para fibras da casca de coco verde em substituição parcial da madeira e 15\% para a resina poliuretana à base de mamona (sem incluir as perdas).

O fator experimental considerado foram as densidades classificadas em alta, média e baixa. Para os painéis fabricados no Laboratório de Construções Rurais e Ambiência de FZEA/USP de Pirassununga foram estabelecidas densidades com faixas variando entre 350 $\mathrm{kg} / \mathrm{m}^{3}$ para baixa densidade; $600 \mathrm{~kg} / \mathrm{m}^{3}$ para média densidade e $850 \mathrm{~kg} / \mathrm{m}^{3}$ para alta densidade, como descrito a seguir neste trabalho. As densidades foram escolhidas para se aproximarem ao máximo dos parâmetros e requisitos das normas ABNT NBR 14810-2: 2013 - Painéis de partículas de média densidade: Requisitos e métodos de ensaio e ANSI A208.1-1999 Particleboard e dos núcleos dos painéis sanduíche comerciais existentes.

O Quadro 9 é dividido em duas seções, onde a primeira parte apresenta os parâmetros e variáveis do processo de produção dos painéis de partículas de subprodutos da agroindústria e a segunda o delineamento experimental dos tratamentos.

O delineamento experimental foi composto por quatro tratamentos, todos os tratamentos foram utilizados como componentes do núcleo dos painéis sanduíches (NS), o tratamento $\mathrm{T} 1$ representa o painel aglomerado de partículas de subprodutos da agroindústria de baixa densidade (NS1-BD), o tratamento T2 painel aglomerado de partículas de subprodutos da agroindústria de média densidade (NS2-MD), o tratamento T3 painel aglomerado de partículas de subprodutos da agroindústria de alta densidade (NS3-AD) e o tratamento T4 painel comercial aglomerado de partículas de madeira de média densidade (NS4-MDP). 
Quadro 9 - Delineamento experimental para os painéis de partículas aglomeradas de subprodutos da agroindústria

\begin{tabular}{|c|c|c|c|}
\hline \multicolumn{4}{|c|}{ Parâmetros e variáveis de produção } \\
\hline \multicolumn{2}{|c|}{ Comprimento médio das partículas de madeira } & \multicolumn{2}{|c|}{$2-8 \mathrm{~mm}$} \\
\hline \multicolumn{2}{|c|}{ Comprimento médio das fibras de coco verde } & \multicolumn{2}{|c|}{$1-4 \mathrm{~mm}$} \\
\hline \multicolumn{2}{|c|}{ Densidade média experimental de projeto proposta } & \multicolumn{2}{|c|}{$(350 ; 600$ e 850$) \mathrm{kg} / \mathrm{m}^{3}$} \\
\hline \multicolumn{2}{|c|}{ Espessura média do painel híbrido } & \multicolumn{2}{|c|}{$15 \mathrm{~mm}$} \\
\hline \multicolumn{2}{|c|}{ Quantidade de resina com perdas } & \multicolumn{2}{|c|}{$15 \%$ da massa seca das partículas } \\
\hline \multicolumn{2}{|c|}{ Pressão de adensamento } & \multicolumn{2}{|c|}{$5 \mathrm{MPa}$} \\
\hline \multicolumn{2}{|c|}{ Temperatura de prensagem } & \multicolumn{2}{|c|}{$100^{\circ} \mathrm{C}$} \\
\hline \multicolumn{2}{|c|}{ Tempo de prensagem } & \multicolumn{2}{|c|}{$10 \mathrm{~min}$} \\
\hline \multicolumn{4}{|c|}{ Tratamento experimental } \\
\hline Tratamento & Configuração & Densidade média & Teor de adesivo \\
\hline T1: (NS1-BD) & $30 \%$ coco $/ 70 \%$ madeira & 350 & 15 \\
\hline T2: (NS2-MD) & $30 \%$ coco $/ 70 \%$ madeira & 600 & 15 \\
\hline T3: (NS3-AD) & $30 \% \operatorname{coco} / 70 \%$ madeira & 850 & 15 \\
\hline T4: (NS4-MDP) & MDP comercial & $(551-750)$ & ---- \\
\hline
\end{tabular}

Fonte: Própria autoria.

\subsubsection{Preparação dos corpos de prova}

As amostras foram preparadas e esquadrejadas para os ensaios de caracterização físicos, mecânicos e térmicos com auxílio de uma serra elétrica de bancada (Figura 39). As quantidades e dimensões dos corpos de provas estão resumidas no (Quadro 10).

Figura 39 - Serra elétrica de bancada para preparação de corpos de prova

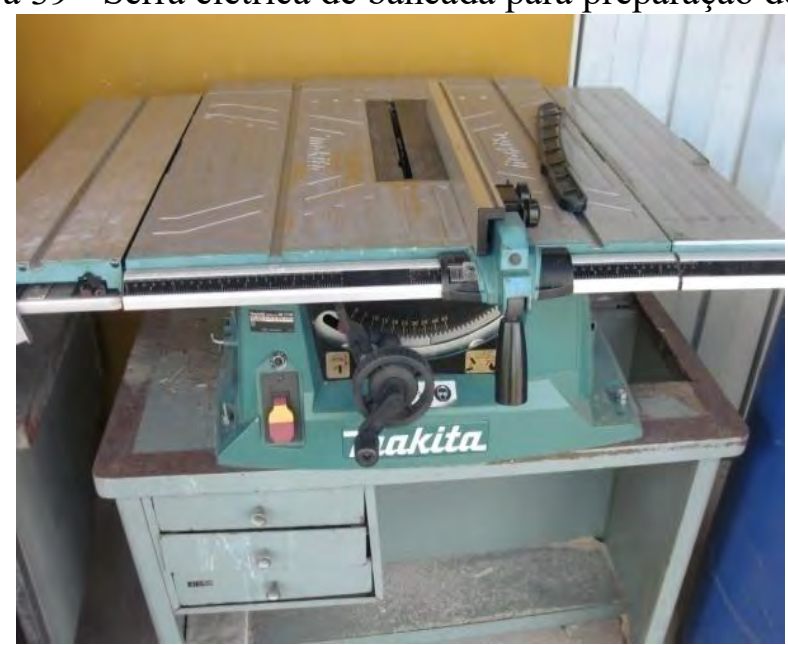

Fonte: Própria autoria. 
Quadro 10 - Planejamento de corte dos corpos de prova dos painéis de partículas aglomeradas

\begin{tabular}{|l|c|c|c|}
\hline \multicolumn{4}{|c|}{ Dimensões e quantidades de corpos de prova avaliados } \\
\hline Propriedades & Comprimento $(\mathrm{mm})$ & Largura $(\mathrm{mm})$ & Quantidade \\
\hline Teor de umidade & 50 & 50 & 40 \\
\hline Densidade & 50 & 50 & 40 \\
\hline $\begin{array}{l}\text { Inchamento durante 24 } \\
\text { horas }\end{array}$ & 50 & 50 & 40 \\
\hline $\begin{array}{l}\text { Módulo de resistência à } \\
\text { flexão estática e módulo } \\
\text { de elasticidade }\end{array}$ & 20 x espessura +50 & 50 & 40 \\
\hline $\begin{array}{l}\text { Resistência à tração } \\
\text { perpendicular }\end{array}$ & 50 & 50 & 40 \\
\hline Condutividade térmica & Circular & Diametral = 50 & 20 \\
\hline
\end{tabular}

Fonte: ABNT NBR 14810-2: 2013 - Painéis de partículas de média densidade.

\subsubsection{Caracterização física, mecânica e térmica dos painéis de partículas} aglomerados

Para a preparação dos corpos de prova e realização dos ensaios físicos e mecânicos seguiu-se as diretrizes da norma ABNT NBR 14810-2: 2013 - Painéis de partículas de média densidade: Requisitos e métodos de ensaio e da norma internacional ASTM D 1037 - 06a Standard Test Methods for Evaluating Properties of Wood-base Fiber and Particle Panel Materials; para determinar as seguintes propriedades: densidade aparente (D); inchamento da espessura em 24 horas (I) e teor de umidade (Um); módulo de resistência à flexão estática (módulo de ruptura - MOR); módulo de elasticidade na flexão (MOE); resistência à tração perpendicular (adesão interna - TP) e arranque de parafuso na superfície e no topo (APS e APT respectivamente).

Para a preparação dos corpos de prova e realização do ensaio de condutividade térmica dos painéis de partículas e da placa de fibrocimento seguiu-se os procedimentos descritos pela norma ASTM E1530-11 - Evaluating the Resistance to Thermal Transmission of Material by the Guarded Heat Flow Meter Technique e conforme trabalhos de (BALLESTEROS, 2014 e BONILLA BUENO, 2015).

Posteriormente a preparação dos corpos de prova e antes dos ensaios, com exceção do ensaio para a determinação do teor de umidade, os corpos de prova foram armazenados em 
camara climática até atingirem a umidade de equilíbrio (Figura 40), condicionados em meio ambiente com $(65 \pm 5) \%$ de umidade relativa e temperatura de $(20 \pm 3){ }^{\circ} \mathrm{C}$, seguindo as diretrizes da norma ABNT NBR 14810-2: 2013. A umidade de equilíbrio foi atingida quando as massas dos corpos de prova se encontram estabilizada, isto é, em um intervalo de 24 horas não apresentou diferença de massa em $0,1 \%$.

Figura 40 - Câmara climática com amostras dos painéis aglomerados de subprodutos da agroindústria e MDP comercial para estabilização

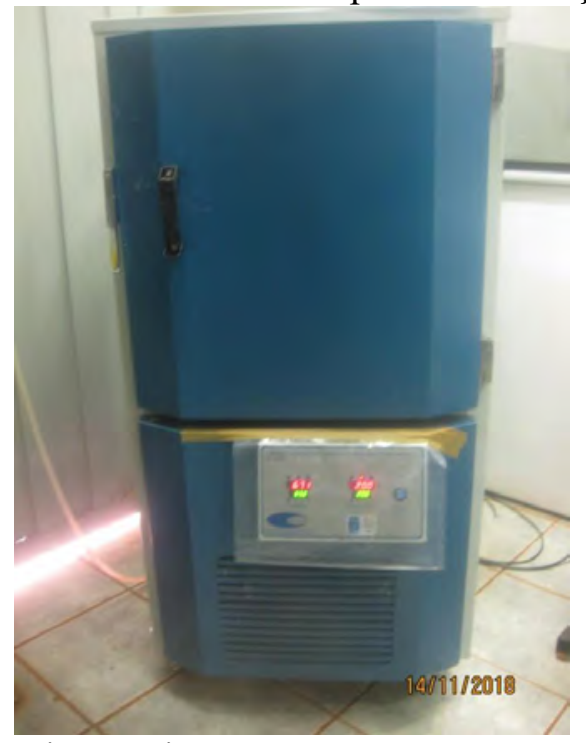

Fonte: Própria autoria.

Os resultados obtidos na caracterização físico-mecânica dos painéis foram analisados sob as prescrições da norma internacional ANSI A208.1 - 1999 Particleboard e da norma ABNT NBR 14810-2: 2013 - Painéis de partículas de média densidade.

Com os resultados da caracterização térmica dos painéis seguindo as prescrições da norma ABNT NBR 15220 Desempenho térmico de edificações parte 2: Métodos de calculo da transmitância térmica, da capacidade térmica, do atraso térmico e do fator solar de elementos e componentes de edificações, foi avaliada a propriedade térmica dos painéis de partículas e da placa de fibrocimento isoladamente.

Finalmente os resultados dos tratamentos (NS1 - BD, NS2 - MD e NS3 - AD) dos painéis de partículas homogêneas aglomeradas de subprodutos da agroindústria foram comparados aos resultados do painel comercial MDP (NS4 - MDP). 


\subsubsection{Caracterização física das amostras dos painéis de partículas}

\section{- Teor de umidade}

A caracterização do teor de umidade segue as diretrizes da ABNT NBR 14810-2: 2013 - Painéis de partículas de média densidade: Requisitos e métodos de ensaio, onde foram preparados 40 corpos de provas com dimensões de $50 \mathrm{~mm}$ x $50 \mathrm{~mm}$ x $15 \mathrm{~mm}, 10$ corpos de prova para cada tratamento proposto no delineamento experimental. Após medir suas massas (massa úmida) em uma balança eletrônica digital analítica, foram acondicionados em estufa com circulação de ar por $24 \mathrm{~h}$ a uma temperatura média de $\left(105 \pm 3{ }^{\circ} \mathrm{C}\right)$, até que as amostras obtivessem massa constante. Finalmente foram feitas medições (massa seca) que não diferiram em $0,1 \%$ em um intervalo mínimo de 6 horas. Para o cálculo do valor do teor de umidade (U) aplicou-se a equação (1):

O resultado é a média das absorções de cada corpo de prova analisado, expresso em porcentagem (\%), com precisão de $0,1 \%$.

\section{- Densidade}

Seguindo a diretriz da norma ABNT NBR 14810-2: 2013 - Painéis de partículas de média densidade: Requisitos e métodos de ensaio foram preparados 40 corpos de provas $(\mathrm{CP})$ com dimensões de $50 \mathrm{~mm}$ × $50 \mathrm{~mm}$ × $15 \mathrm{~mm}, 10$ corpos de prova para cada tratamento proposto no delineamento experimental. Após aferidos em uma balança eletrônica digital analítica, mediu-se a espessura no ponto de intersecção das diagonais da face das amostras e as dimensões laterais em dois pontos paralelos distintos de cada lado determinando sua largura média e finalmente o volume de cada corpo de prova. Foram determinadas as densidades de cada amostra dos painéis de partículas por meio da equação (4):

$$
D=\frac{m}{v}(4)
$$

Sendo:

$v=b 1 * b 2 * e$

Onde:

$\mathrm{D}=$ densidade do $\mathrm{CP}$ expressa em quilograma por metro cúbico $\left(\mathrm{kg} / \mathrm{m}^{3}\right)$; 
$\mathrm{m}=$ massa do $\mathrm{CP}$ expressa em gramas $\mathrm{g}$;

$\mathrm{v}=$ volume do CP expressa em milímetros cúbicos $\left(\mathrm{mm}^{3}\right)$;

b1 e b2 = dimensões laterais do corpo de prova, expressa em milímetros (mm);

e = espessura do corpo de prova, expressa em milímetros ( $\mathrm{mm})$.

Calcula-se a densidade média (Dmédia) expressando o resultado em quilogramas por metro cúbico, com precisão de $1 \mathrm{~kg} / \mathrm{m}^{3}$.

\section{- Inchamento da espessura em 24 horas}

Seguindo a diretriz da norma ABNT NBR 14810-2: 2013 - Painéis de partículas de média densidade: Requisitos e métodos de ensaio foram preparados 40 corpos de provas (CP) com dimensões de $50 \mathrm{~mm}$ x $50 \mathrm{~mm}$ x $15 \mathrm{~mm}, 10$ corpos de prova para cada tratamento proposto no delineamento experimental. Foram medidas as espessuras no encontro das diagonais das amostras com um paquímetro e após os corpos de prova submersos $25 \mathrm{~mm}$ abaixo da superfície em água destilada com temperatura de $20{ }^{\circ} \mathrm{C}$ onde se iniciou o ensaio (Figura 41).

Figura 41 - Amostras de painéis aglomerado de subprodutos da agroindústria e MDP comercial submersas

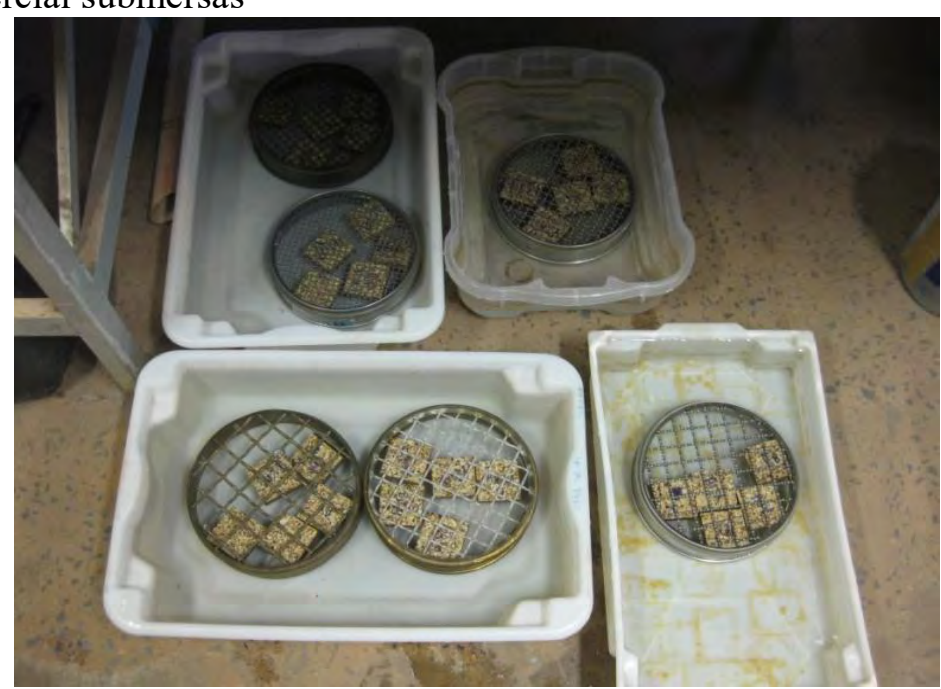

Fonte: Própria autoria.

Passado (24 h \pm 36 min.) o período normativo de imersão retirou-se os corpos de prova do recipiente e removeu-se o excesso de água com papel absorvente realizando a medida da espessura novamente. $O$ cálculo do inchamento foi determinado pela equação (5): 


$$
I=\frac{E 1-E 2}{E 2} * 100(5)
$$

Onde:

$\mathrm{I}=$ Inchamento da espessura do CP, expresso em porcentagem (\%);

$\mathrm{E} 1$ = Espessura do $\mathrm{CP}$ após o período de imersão considerado; expressa em milímetros (mm);

$\mathrm{E} 2$ = Espessura do CP antes da imersão, expressa em milímetros (mm).

O resultado é a média dos inchamentos de cada corpo de prova analisado, expresso em porcentagem $(\%)$, com precisão de $0,1 \%$.

\subsubsection{Caracterização mecânica das amostras dos painéis de partículas}

Seguindo as diretrizes da norma ABNT NBR 14810-2: 2013 - Painéis de partículas de média densidade: Requisitos e métodos de ensaio, antes dos ensaios, os corpos de prova foram armazenados em ambiente climatizado, condicionados em meio ambiente com (65 \pm 5$)$ $\%$ de umidade relativa e temperatura de $(20 \pm 3){ }^{\circ} \mathrm{C}$ para que atingissem a umidade de equilíbrio. A umidade de equilíbrio foi confirmada quando a pesagem dos corpos de prova se encontrou estabilizada, isto é, em um intervalo de 24 horas não apresentou diferença de massa em $0,1 \%$.

\section{- MOR (Módulo de resistência à flexão estática) e MOE (Módulo de} elasticidade)

Seguindo a diretriz da norma ABNT NBR 14810-2: 2013 - Painéis de partículas de média densidade: Requisitos e métodos de ensaio foram preparados 40 corpos de provas (CP) com dimensões de $350 \mathrm{~mm}(20$ x espessura $+50 \mathrm{~mm})$ x $50 \mathrm{~mm}$ x $15 \mathrm{~mm}, 10$ corpos de prova para cada tratamento do delineamento experimental. Foram aferidas as medidas das dimensões das amostras com um paquímetro e inseridas no software Tesc versão 1.3 (unidade de aquisição de dados), a máquina universal de ensaios mecânicos (Figura 42) transmitiu as informações do atuador de carga ao software até a finalização do ensaio. 
Figura 42 - Máquina universal de ensaios mecânicos EMIC

Fonte: Própria autoria.

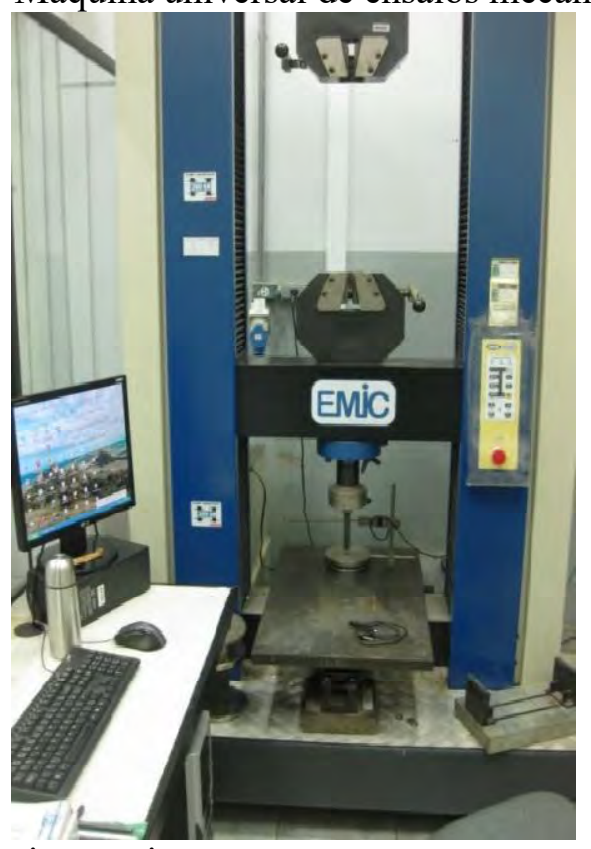

Cada amostra foi posicionada sobre os apoios da máquina universal (Figura 43), os apoios foram distanciados em 20 vezes a dimensão da espessura média dos corpos de prova e submetidos ao ensaio de flexão estática.

Figura 43 - Corpo de prova do painel aglomerado de subprodutos da agroindústria posicionado na máquina universal EMIC durante ensaio de flexão

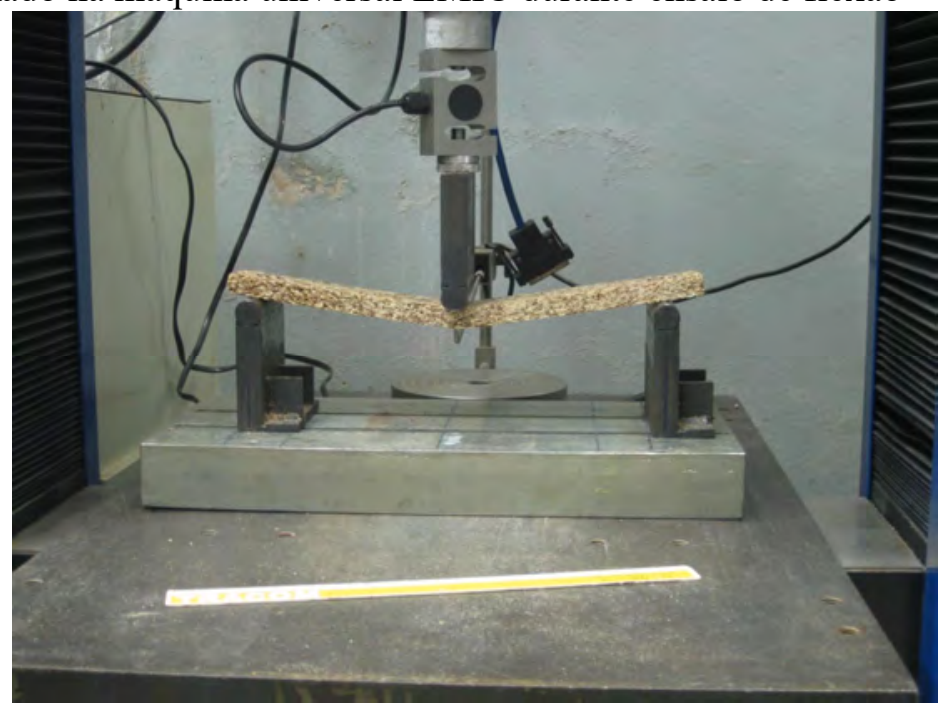

Fonte: Própria autoria. 
O ensaio ocorreu a uma velocidade ideal de $5 \mathrm{~mm} / \mathrm{min}$ para que a ruptura das amostras acontecesse no intervalo de $(60 \pm 30)$ s, após a ruptura determinou-se a força máxima aplicada em cada corpo de prova e a posterior geração de arquivo txt proporcionou futuras análises de cada ensaio. Para o calculo dos valores do módulo de ruptura (MOR) e de elasticidade (MOE) foram utilizadas as equações (6) e (7):

$$
\begin{aligned}
& M O R=1,5 * \frac{(P * D)}{B *(E)^{2}}(6) \\
& M O E=\frac{\left(P 1 * D^{3}\right)}{4 * B *\left(E^{3}\right)} * d(7)
\end{aligned}
$$

Onde:

MOR = módulo de resistência à flexão estática, expresso em newtons por milímetro quadrado $\left(\mathrm{N} / \mathrm{mm}^{2}\right)$;

$\mathrm{P}=$ carga de ruptura expressa em Newton $(\mathrm{N})$;

$\mathrm{D}=$ distância entre os apoios da máquina universal de ensaio, expressa em milímetros (mm);

$\mathrm{B}=$ largura do corpo de prova, expressa em milímetros $(\mathrm{mm}) ;$

$\mathrm{E}=$ espessura do corpo de prova, expressa em milímetros ( $\mathrm{mm})$.

MOE = módulo de elasticidade, expresso em Newton por milímetro quadrado $\left(\mathrm{N} / \mathrm{mm}^{2}\right)$;

$\mathrm{P} 1$ = carga no limite de proporcionalidade, expressa em $(\mathrm{N})$;

$\mathrm{D}=$ distância entre os apoios da máquina universal de ensaio, expressa em milímetros (mm);

$\mathrm{d}=$ deflexão correspondente a $\mathrm{P} 1$, expressa em milímetros ( $\mathrm{mm})$;

$\mathrm{B}=$ largura do corpo de prova, expressa em milímetros ( $\mathrm{mm})$;

$\mathrm{E}=$ espessura do corpo de prova, expressa em milímetros (mm).

O resultado do ensaio é a media dos resultados dos corpos de prova com precisão de $1 \mathrm{~N} / \mathrm{mm}^{2}$ para o MOR e $10 \mathrm{~N} / \mathrm{mm}^{2}$ para o MOE. 


\section{- Resistência à tração perpendicular}

Seguindo a diretriz da norma ABNT NBR 14810-2: 2013 - Painéis de partículas de média densidade: Requisitos e métodos de ensaio foram preparados 40 corpos de provas (CP) com dimensões de $50 \mathrm{~mm}$ x $50 \mathrm{~mm} \times 15 \mathrm{~mm}, 10$ corpos de prova para cada tratamento do delineamento experimental. Com um paquímetro foram medidas as dimensões laterais em dois pontos paralelos distintos de cada lado dos corpos de prova classificados como b1 e b2. Após serem colados nos blocos de tração perpendicular (Figura 44) com um adesivo de secagem rápida, os corpos de prova foram posicionados na máquina universal de ensaio (a mesma descrita para o ensaio de MOR e MOE) e submetidos a esforços de tração a uma velocidade ideal de $6 \mathrm{~mm} / \mathrm{min}$ para que a ruptura ocorresse no intervalo de $(60 \pm 30) \mathrm{s}$.

Figura 44 - Corpo de prova de painel MDP comercial ensaiado no bloco de tração

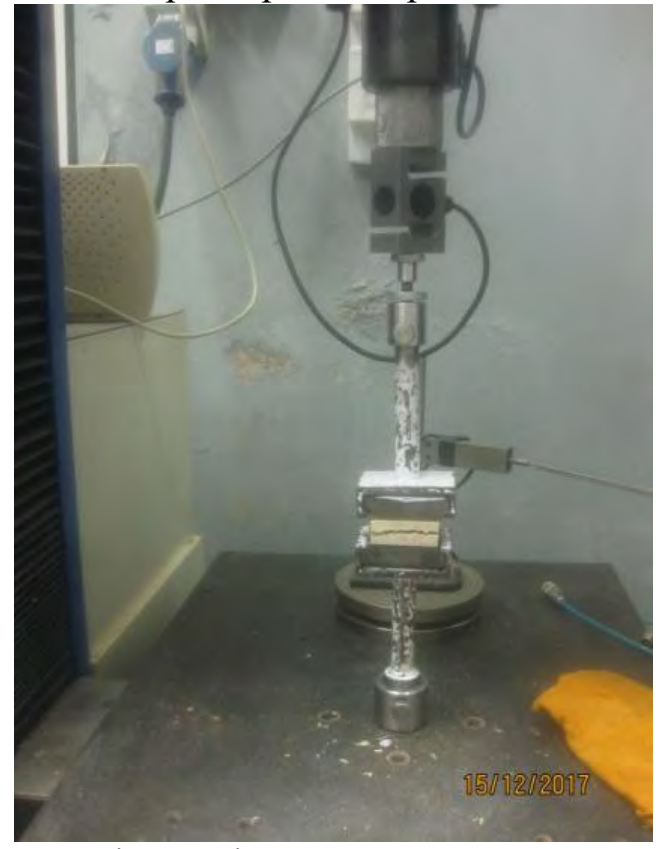

Fonte: Própria autoria.

Terminado os ensaios, e com os valores de carga fornecidos pelo computador interligado ao equipamento de teste, determinou-se a adesão interna de cada amostra do painel de partículas por meio da equação (8):

$$
T P=\frac{P}{S}(8)
$$

Sendo:

$$
S=b 1 X b 2
$$


Onde:

$\mathrm{TP}=$ resistência à tração perpendicular, expressa em Newton por milímetro quadrado $\left(\mathrm{N} / \mathrm{mm}^{2}\right)$;

$\mathrm{P}=$ carga de ruptura, expressa em Newton $(\mathrm{N})$;

$\mathrm{S}=$ área da superfície da amostra, expressa em milímetros quadrados $\left(\mathrm{mm}^{2}\right)$;

b1 e b2 = dimensões do corpo de prova, expressas em milímetros (mm).

O resultado do ensaio é a media dos resultados dos corpos de prova com precisão de $0,01 \mathrm{~N} / \mathrm{mm}^{2}$.

\section{- Arranque de parafuso na superfície e topo}

Seguindo a diretriz da norma ABNT NBR 14810-2: 2013 - Painéis de partículas de média densidade: Requisitos e métodos de ensaio foram preparados 40 corpos de provas (CP) com dimensões de $50 \mathrm{~mm}$ x $50 \mathrm{~mm}$ x $15 \mathrm{~mm}, 10$ corpos de prova para cada tratamento do delineamento experimental. Após seguir os procedimentos de perfuração e fixação dos parafusos (Figura 45), os corpos de prova foram posicionados na máquina universal de ensaio (a mesma descrita para o ensaio de MOR e MOE) e submetidos a esforços de tração a uma velocidade ideal de $10 \mathrm{~mm} / \mathrm{min}$., terminado o ensaio o valor foi registrado no indicador de carga e expresso em Newton com precisão de $0,1 \mathrm{~N}$.

Figura 45 - Corpo de prova de painel aglomerado de subprodutos da agroindústria em ensaio de arranque de parafuso na superfície e no topo
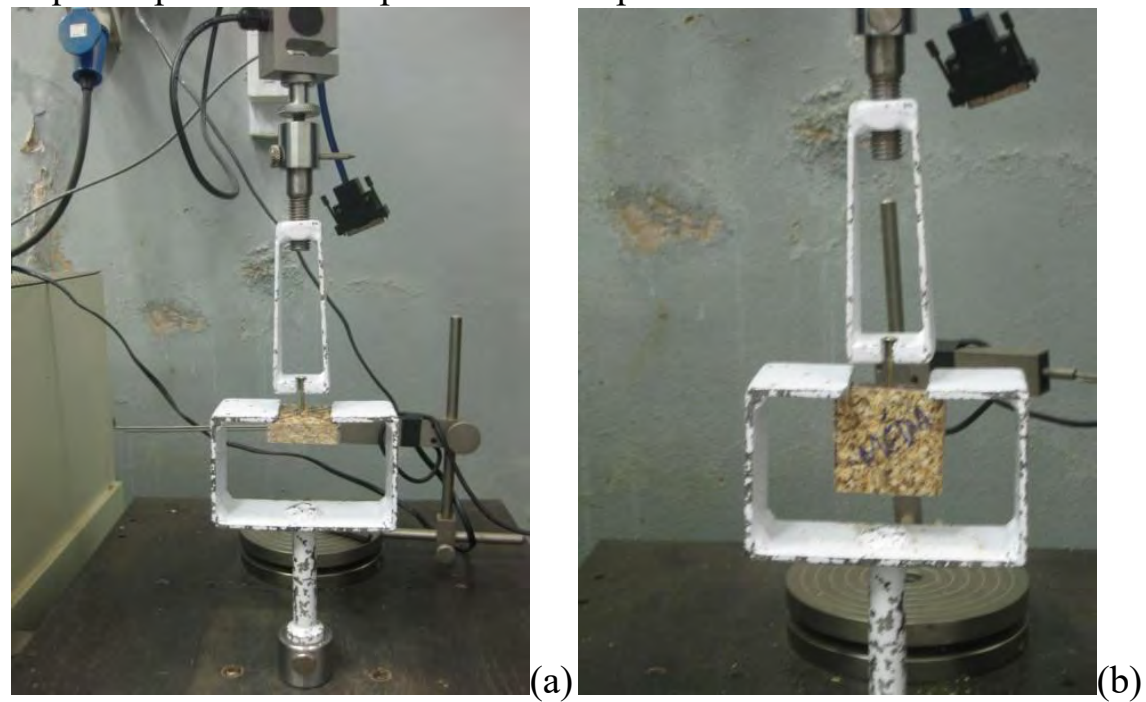

(a) Arranque de parafuso na superfície (b) Arranque de parafuso no topo Fonte: Própria autoria. 


\subsubsection{Análise da condutividade e resistência térmica das amostras dos} painéis de partículas

A condutividade térmica pode ser considerada como uma propriedade natural dos materiais homogêneos e isotrópicos, considerando que materiais fibrosos, celulares e granulares são termicamente homogêneos, o conceito de condutividade térmica pode ser empregado para descrever seu comportamento em diversas aplicações (ABNT NBR 15220-4: 2003 - Desempenho térmico de edificações Parte 4: medição da resistência térmica e da condutividade térmica pelo princípio da placa quente protegida). A resistência térmica de elementos e componentes são definidas como a relação de equivalência entre a diferença de temperatura verificada entre as superfícies de um elemento ou componente construtivo pela densidade do fluxo de calor (ABNT NBR 15220-1: 2003 - Desempenho térmico de edificações Parte 1: Definições, símbolos e unidades).

Similarmente ao trabalho de Ballesteros (2014), para a avaliação da condutividade térmica dos painéis de partículas foram preparados oito corpos de prova com dimensões diametrais de 5 centímetros e 15 milímetros de espessura para os painéis de partículas homogêneas. $\mathrm{O}$ autor descreveu a necessidade de utilizar uma pasta térmica entre a amostra e o equipamento nas faces inferiores e superiores com o propósito de reduzir a resistência.

Bonilla Bueno (2015) também seguiu as diretrizes da norma ASTM E1530-11 Evaluating the resistance to Thermal Transmission of Material by the Guarded Heat Flow Meter Technique para determinar a condutividade e resistência térmica dos painéis de partículas. As dimensões das amostras seguem as diretrizes da norma e para o ensaio foi utilizado o equipamento DTC-300 modelo 2022 (Figura 46). A norma descreve que o corpo de prova faz um sanduíche com as placas controladoras de temperatura, onde ocorre o fluxo de calor. 
Figura 46 - Equipamento de medição de condutividade térmica DTC-300

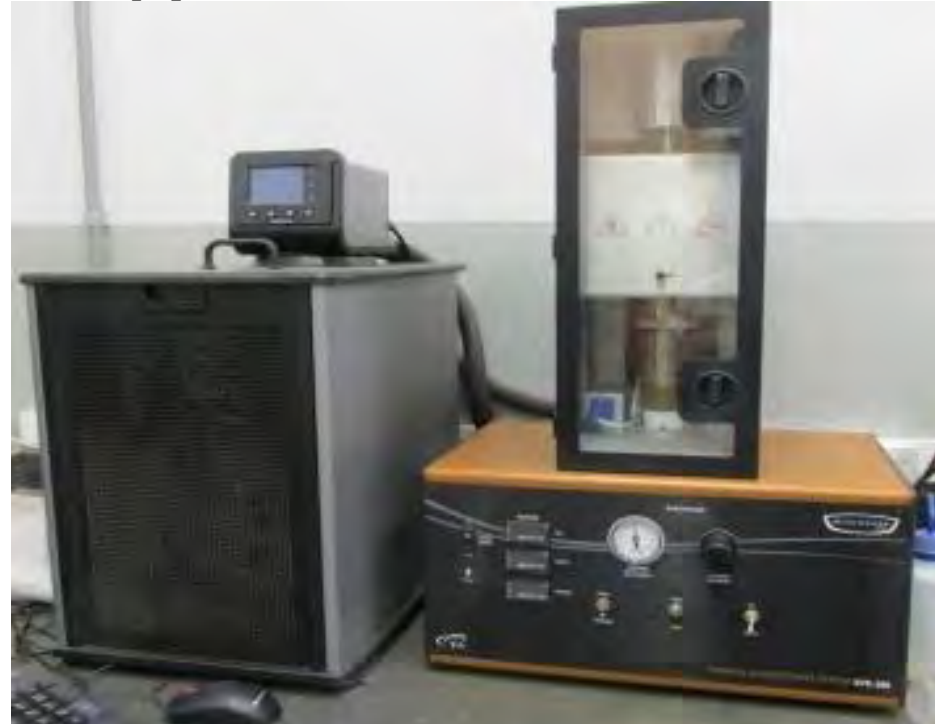

Fonte: Própria autoria.

No estado estacionário do sistema mediram-se as diferenças de temperatura entre as superfícies, assim determinou-se a condutividade e calculou-se resistência térmica conforme as equações (9) e (10):

$$
\begin{gathered}
\text { Rtermica }=N\left[\frac{T u-T m}{Q}\right]-\operatorname{Rint}(9) \\
\text { Rtermica }=\left[\frac{e}{\lambda}\right](10)
\end{gathered}
$$

Onde:

Rtermica $=$ resistência térmica da amostra expressa em $\left(\mathrm{m}^{2} \mathrm{~K} / \mathrm{W}\right)$;

$\mathrm{Tu}=$ temperatura da placa superior expressa em $\left({ }^{\circ} \mathrm{C}\right) ;$

$\mathrm{Tm}=$ temperatura da placa inferior expressa em $\left({ }^{\circ} \mathrm{C}\right)$;

$\mathrm{Q}=$ fluxo de calor expresso em (W);

Rint $=$ resistência total da interface entre a amostra e a superfície das placas expressa em $\left(\mathrm{m}^{2} \mathrm{~K} / \mathrm{W}\right)$;

$\mathrm{N}=$ constante de calibração do fluxo de calor expresso em $\left(\mathrm{Wm}-{ }^{2} \mathrm{mV}-{ }^{1}\right)$;

$e=$ espessura da amostra expressa em (m) e

$\lambda=$ condutividade térmica expressa em $(\mathrm{W} / \mathrm{mK})$ 


\subsubsection{Diretrizes de recebimento da placa de fibrocimento}

Conforme descrito na seção 3.1.3, as placas de fibrocimento foram adquiridas na indústria de materiais de construção e as propriedades físicas, mecânicas e térmicas foram fornecidas pelo fabricante. A norma ABNT NBR 15.498:2014-Placas de fibrocimento sem amianto estabelece diretrizes de conformidade para a aceitação do produto na seção 9.1. O tipo de placa adquirida recebe a classificação tipo B indicadas para uso interno e aplicações externas não sujeitas à ação direta de sol, chuva, calor e umidade. Alguns requisitos específicos de ensaios de aceitação são: (i) comprimento, largura e espessura e (ii) linearidade das bordas e esquadro. O nível de qualidade aceitável é uma verificação da possível condição do lote da placa de fibrocimento, exigências da norma para garantir conformidade em relação a dimensões e geometrias.

\subsubsection{Preparação dos corpos de prova}

O corte da placa de fibrocimento para a preparação dos corpos de prova ocorreu com o auxílio de uma serra elétrica de bancada com disco diamantado (Figura 47), seguindo um plano de corte e preparação de corpos de prova de acordo com as diretrizes da RILEM TECHNICAL COMITTEE 49 TRF - Testing Methods for Fibre Reinforced Cement-Based Composites e ASTM E1530-11 - Evaluating the Resistance to Thermal Transmission of Material by the Guarded Heat Flow Meter Technique, as amostras foram preparadas para a determinação das características físicas, mecânicas e térmicas conforme (Quadro 11). Antes dos ensaios as amostras foram preparadas de acordo com as diretrizes de cada norma específica.

Figura 47 - Serra de corte para materiais cimentícios

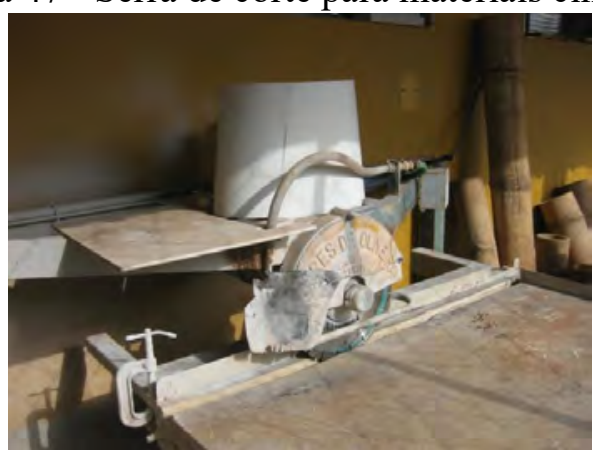

Fonte: Própria autoria. 
Quadro 11 - Planejamento de corte dos corpos de prova da placa de fibrocimento

\begin{tabular}{|l|c|c|c|}
\hline \multicolumn{4}{|c|}{ Dimensões e quantidades de corpos de prova avaliados } \\
\hline \multicolumn{1}{|c|}{ Propriedades } & Comprimento $(\mathrm{mm})$ & Largura $(\mathrm{mm})$ & Quantidade \\
\hline AA, PA, DA e DS & 50 & 50 & 6 \\
\hline $\begin{array}{l}\text { Módulo de resistência à flexão } \\
\text { estática, limite de } \\
\text { proporcionalidade e módulo de }\end{array}$ & 160 & 50 & 6 \\
\hline Condutividade térmica & Circular & Diametral $=50$ & 8 \\
\hline
\end{tabular}

Fonte: RILEM - Testing Methods for Fibre Reinforced Cement-Based Composites e ASTM E1530-11 - Evaluating the Resistance to Thermal Transmission of Material by the Guarded Heat Flow Meter Technique.

\subsubsection{Caracterização físico-mecânica e térmica da placa de fibrocimento}

Foram realizados ensaios físicos-mecânicos seguindo as diretrizes da norma específica conforme cada propriedade a ser determinada.

O ensaio de tração na flexão segue diretrizes da RILEM TECHNICAL COMITTEE 49 TRF - Testing Methods for Fibre Reinforced Cement-Based Composites, e foram determinadas as seguintes propriedades mecânicas: módulo de elasticidade (MOE) expresso em MPa, limite de proporcionalidade (LOP) expresso em MPa, módulo de ruptura (MOR) expresso em MPa e energia específica (EE) expressa em $\mathrm{KJ} / \mathrm{m}^{2}$.

A determinação dos valores médios das propriedades físicas tais como, absorção de água (AA), porosidade aparente (PA), densidade aparente saturada (DA) e densidade aparente seca (DS) das placas de fibrocimento foram obtidas pelo método de imersão e seguiram as diretrizes da (Testing Methods for Fibre Reinforced Cement-Based Composites - RILEM).

Para o ensaio de condutividade térmica das placas de fibrocimento seguiram-se os procedimentos descritos pela norma ASTM E1530-11 - Evaluating the Resistance to Thermal Transmission of Material by the Guarded Heat Flow Meter Technique e conforme trabalhos de (BALLESTEROS, 2014; BONILLA BUENO, 2015).

Os resultados das propriedades testadas foram comparados com referências da norma ABNT NBR 15498:2014-Placas de fibrocimento sem amianto e com catálogos de empresas que fabricam produtos similares e que atendem as normas vigentes para produtos cimentícios. 


\subsubsection{Caracterização física das amostras da placa de fibrocimento}

A amostragem foi composta por seis corpos de prova com volume mínimo de $25 \mathrm{~cm}^{3}$ cada um, com espessuras inferiores a 12,5 mm. Recomenda-se que o corpo de prova tenha largura mínima de $50 \mathrm{~mm}$ e comprimento mínimo de $160 \mathrm{~mm}$. Os corpos-de-prova foram submersos em água por $24 \mathrm{~h}$ à temperatura ambiente (Figura 48), depois desse período pesouse a massa imersa (Figura 49) posteriormente retirou-se o corpo-de-prova do recipiente, o excesso de água foi eliminado com o auxilio de um pano úmido limpo e outro seco e posteriormente mediu-se a massa úmida em balança digital analítica (Testing Methods for Fibre Reinforced Cement-Based Composites - RILEM).

Finalmente após a secagem das amostras por $24 \mathrm{~h}$, a uma temperatura média de (105 $\pm 5^{\circ} \mathrm{C}$ ) em estufa com circulação de ar, em uma balança eletrônica digital analítica com precisão de $0,1 \mathrm{~g}$, foram medidas as massas seca das amostras experimentais utilizando o critério de que as leituras não variem em 0,5\% (Testing Methods for Fibre Reinforced Cement-Based Composites - RILEM).

Figura 48 - Amostras da placa de fibrocimento submersas

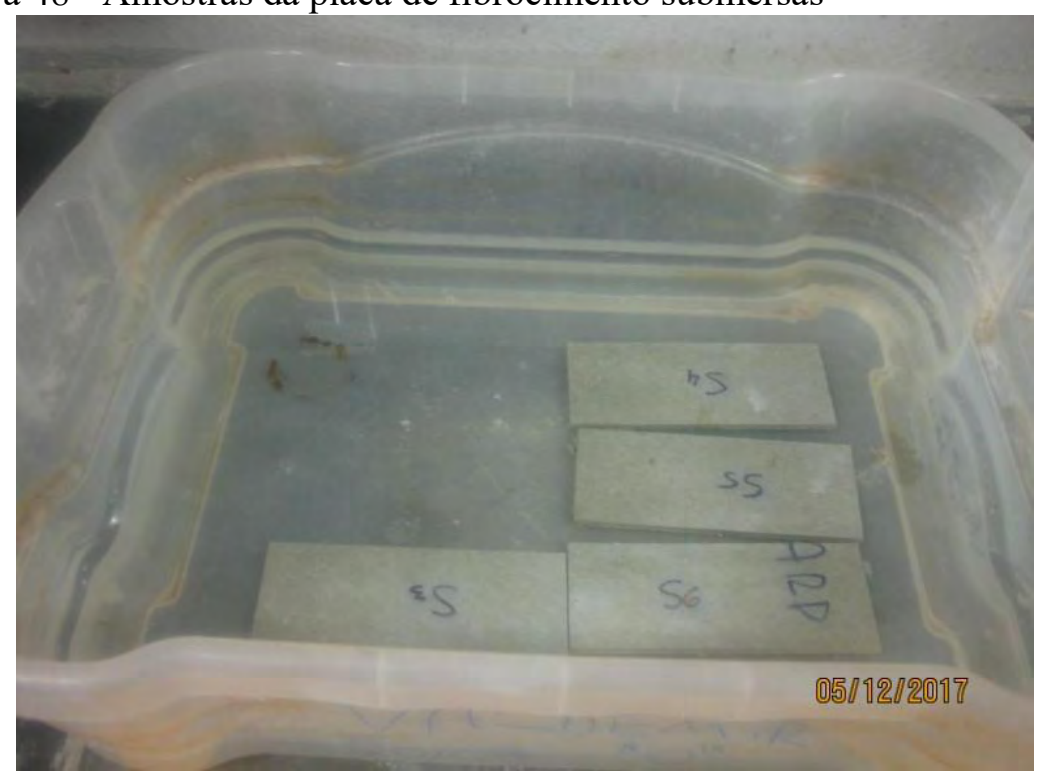

Fonte: Própria autoria. 
Figura 49 - Amostra da placa de fibrocimento em pesagem imersa

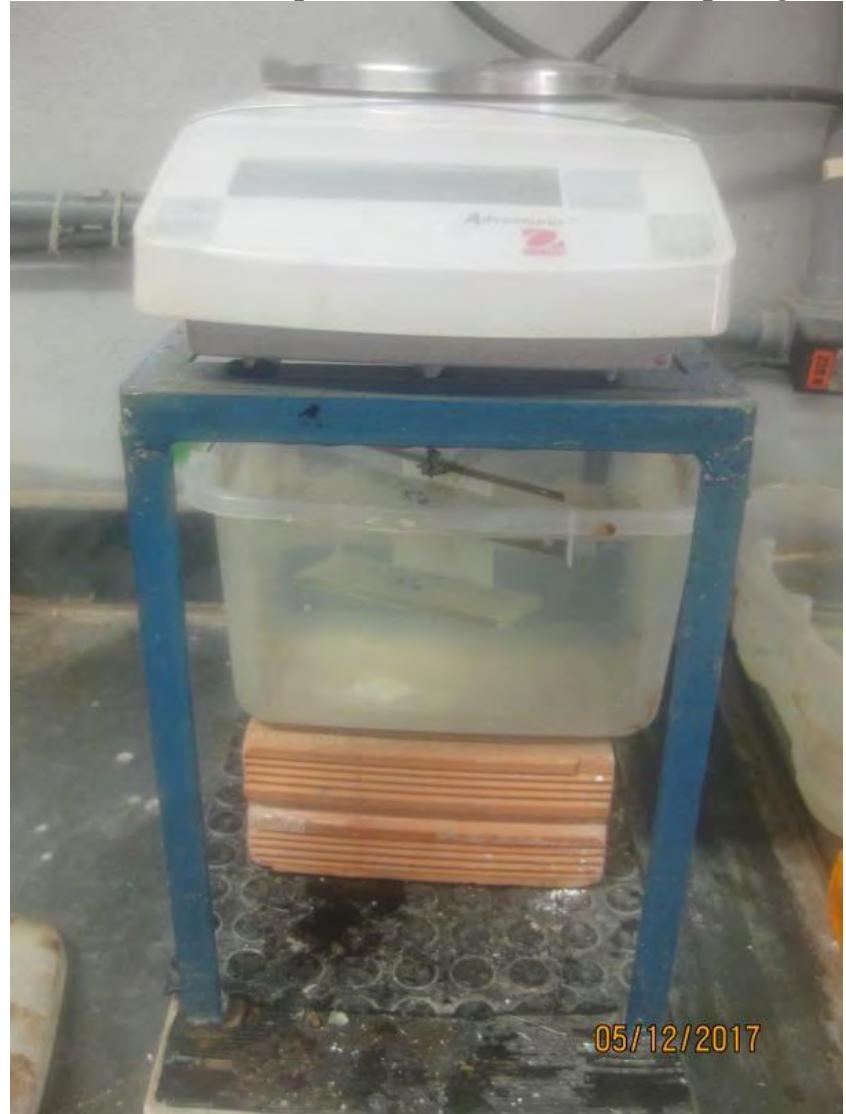

Fonte: Própria autoria.

Com o método adotado as propriedades obtidas foram: absorção de água, densidade aparente saturada, porosidade aparente e densidade aparente seca foram aplicadas as equações (11), (12), (13) e (14) respectivamente:

$$
\begin{aligned}
& A A=\left(\frac{M_{\text {sat }}-M_{\text {sec }}}{M_{\text {sec }}}\right) * 100(11) \\
& D A=\left(\frac{M_{\text {sec }}}{M_{\text {sat }}-M_{\text {ime }}}\right) * D(12) \\
& P A=\left(\frac{M_{\text {sat }}-M_{\text {sec }}}{M_{\text {sat }}-M_{\text {ime }}}\right) \times 100(13) \\
& D S=\left(\frac{M_{\text {sec }}}{M_{\text {sat }}-M_{\text {ime }}}\right) \times D(13)
\end{aligned}
$$


Onde:

$\mathrm{AA}=$ absorção de água expressa em (\%);

$\mathrm{DA}=$ densidade aparente saturada expressa em $\left(\mathrm{g} / \mathrm{cm}^{3}\right)$;

$\mathrm{PA}=$ porosidade aparente expressa em $(\%)$;

$\mathrm{DS}=$ densidade aparente seca $\left(\mathrm{g} / \mathrm{cm}^{3}\right)$;

$\mathrm{M}_{\mathrm{sat}}=$ massa do compósito saturado em água e com superfície seca expressa em (g);

$\mathrm{M}_{\mathrm{sec}}=$ massa do compósito seco em estufa expressa em (g);

$\mathrm{M}_{\mathrm{ime}}=$ massa do compósito saturado imerso em água expressa em (g);

$\mathrm{D}=$ densidade da água, expressa em gramas por centímetro cúbico $\left(\mathrm{g} / \mathrm{cm}^{3}\right)$.

Os valores da densidade aparente da placa e absorção de água, segundo a norma ABNT NBR 15498:2014-Placas de fibrocimento sem amianto, devem ser fornecidos pelo fabricante e podem ser comparadas com os resultados obtidos na caracterização.

\subsubsection{Caracterização mecânica das amostras da placa de fibrocimento}

O ensaio tem por objetivo avaliar as tensões de resistência à tração na flexão do material em condições de equilíbrio. Para o ensaio de flexão em quatro pontos foram preparados seis corpos de provas de $50 \mathrm{~mm}$ x $160 \mathrm{~mm}$ com propósito de se obter as propriedades mecânicas das amostras da placa de fibrocimento. Segundo as diretrizes da RILEM TECHNICAL COMITTEE 49 TRF - Testing Methods for Fibre Reinforced CementBased Composites, a execução do ensaio foi feito com o corpo de prova locado entre os apoios inferiores a uma distância de $135 \mathrm{~mm}$ e $45 \mathrm{~mm}$ entre os superiores, a velocidade de deslocamento do atuador de $1,5 \mathrm{~mm} / \mathrm{min}$. O ensaio foi programado para finalizar quando se constatar uma redução de $50 \%$ da carga máxima de ruptura para cálculo da energia específica.

Seguindo as diretrizes da RILEM, antes da realização do ensaio os corpos de prova foram saturados em água, para isso ficaram imersos por um período entre $12 \mathrm{~h}$ e $24 \mathrm{~h}$. Posteriormente foram secos levemente para retirar o excesso de água. Utilizando um paquímetro digital, foram feitas medições da largura e espessura dos corpos-de-prova em 3 pontos diferentes determinando-se os valores médios (Testing Methods for Fibre Reinforced Cement-Based Composites - RILEM).

Com o computador equipado com o software Tesc, versão 1.3, interligado com uma máquina universal de ensaios mecânicos (Figura 45) equipada com deflectômetro para 
medição de pequenas deformações de até $30 \mathrm{~mm}$, foram determinadas as forças aplicadas e as deflexões sofridas por cada corpo de prova. Com os dados obtidos pelo software determinaram-se os valores de módulo de elasticidade, resultado que expressa a rigidez do material, o limite de proporcionalidade obtido com a carga máxima antes de o ensaio apresentar o desvio da linearidade na curva carga versus deformação, módulo de ruptura à tração na flexão definida com a carga máxima expressa na curva tensão versus deformação e energia especifica (energia absorvida dividida pela área da seção transversal dos corpos de prova na região de fratura) de acordo com a norma RILEM TECHNICAL COMITTEE 49 TRF - Testing Methods for Fibre Reinforced Cement-Based Composites.

Para determinar os valores representativos das propriedades módulo de elasticidade (MOE) expresso em MPa, limite de proporcionalidade (LOP) expresso em MPa, módulo de ruptura (MOR) expresso em MPa e energia especifica (EE) expressa em $\mathrm{KJ} / \mathrm{m}^{2}$ foram aplicadas as equações (14), (15), (16) e (17) respectivamente.

$$
\begin{gathered}
M O R=\frac{F 2 * L}{b * d^{2}}(14) \\
L O P=\frac{F 1 * L}{b * d^{2}}(15) \\
M O E=\frac{276 * P *(L)^{3}}{1296 * b * d^{3}} * \alpha \\
E E=\frac{E A}{A}(17)
\end{gathered}
$$

Onde:

F2 = carga máxima aplicada expressa em Newton $(\mathrm{N})$;

$\mathrm{F} 1$ = carga máxima aplicada antes da curva carga $\mathrm{x}$ deformação desviar-se da linearidade expressa em Newton $(\mathrm{N})$;

$\mathrm{P}=$ carga máxima aplicada antes da curva carga $\mathrm{x}$ deformação desviar-se da linearidade (carga no limite proporcional) expressa em Newton $(\mathrm{N})$;

$\mathrm{L}=$ distância entre apoios inferiores expressa em milímetro ( $\mathrm{mm})$; 
$\mathrm{b}=$ largura do corpo-de-prova expressa em milímetro ( $\mathrm{mm})$;

$\mathrm{d}=$ espessura do corpo-de-prova expressa em milímetro ( $\mathrm{mm})$;

$\mathrm{EA}=$ Energia absorvida: área sob a curva do gráfico carga-deformação expressa em Newton por milímetro $(\mathrm{N} / \mathrm{mm})$;

$\mathrm{A}=$ área da seção transversal do corpo-de-prova expressa em milímetro quadrado $\left(\mathrm{mm}^{2}\right)$

$\alpha=$ coeficiente angular da região linear da curva carga versus deformação.

\subsubsection{Análise da condutividade e resistência térmica das amostras da}

\section{placa de fibrocimento}

Como descrito no item 3.2.3.3 realizou-se o ensaio com o equipamento Thermal Condutivity Tester DTC-300 (Figura 49). Similarmente, para a avaliação da condutividade térmica da placa de fibrocimento foram preparados oito corpos de prova com dimensões diametrais de 5 centímetros e 6 milímetros de espessura.

Para o cálculo da resistência térmica aplicaram-se as equações (9) e (10):

\subsubsection{Processo de produção do painel sanduíche}

Os painéis sanduíche foram produzidos, ensaiados e os resultados analisados com a finalidade de estudar sua possível aplicação como componente ou elemento construtivo nos setores da construção civil. Sua produção ocorreu da associação de placas de fibrocimento com painéis aglomerado de partículas homogêneas de subprodutos da agroindústria com densidades médias entre $359 \mathrm{~kg} / \mathrm{m}^{3}$ para baixa densidade; $571 \mathrm{~kg} / \mathrm{m}^{3}$ para média densidade e $777 \mathrm{~kg} / \mathrm{m}^{3}$ para alta densidade e com painel comercial de partículas de madeira de média densidade (MDP) com densidade média de $647 \mathrm{~kg} / \mathrm{m}^{3}$ (Figura 51).

O processo de fabricação do painel sanduíche iniciou-se com a aplicação da resina PU-mamona nas faces dos componentes construtivos, os painéis de partículas foram curados por 72 horas antes do procedimento. Nas placas de fibrocimento aplicaram-se adesivo somente nas faces mais ásperas (Figura 50a e Figura 50b), que foi escolhida como área de contato aos painéis de partículas que por sua vez receberam adesivo em ambas as faces, pois 
fizeram contato tanto com a placa de fibrocimento como entre si (Figura 51a, Figura 51b e Figura 51c).

Figura 50 - Resina PU nas faces da placa de fibrocimento
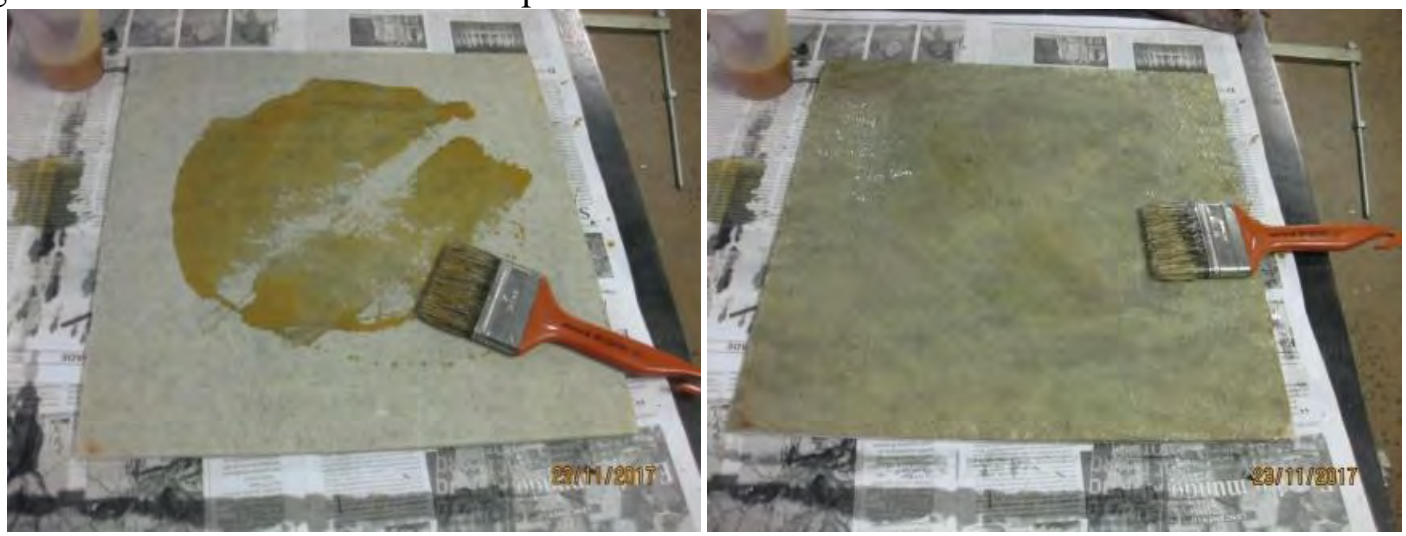

(a) Aplicação de adesivo (b) Superfície recoberta com adesivo Fonte: Própria autoria.

Figura 51 - Resina aplicada sobre as faces dos painéis de partículas aglomeradas de subprodutos da agroindústria e painel MDP comercial

(a)

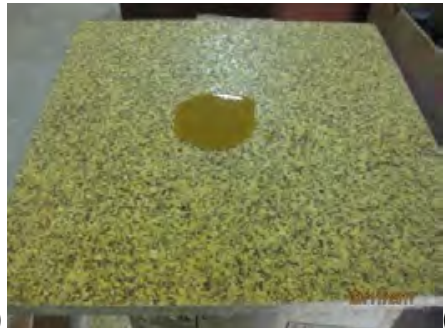

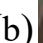

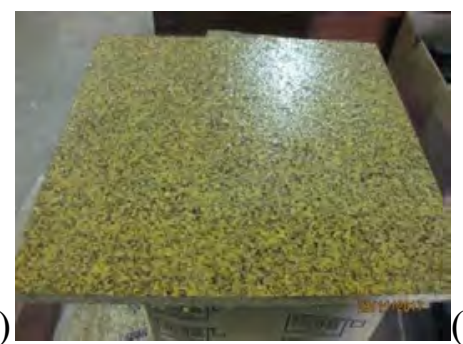

(c)

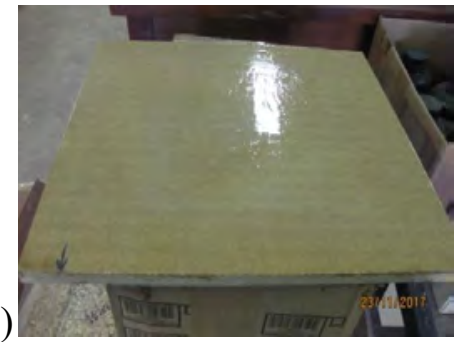

(a) Painel de subprodutos (b) Resina aplicada por completo (c) MDP com resina Fonte: Própria autoria.

Foram aplicados 50 gramas de resina PU a base de óleo de mamona (misturados na proporção 1:1) por face de placas e painéis para a composição proposta, totalizaram-se aproximadamente 300 gramas por painel sanduíche (não considerando as perdas). Durante a prensagem foi observado saída de resina entre as camadas (Figura 52b), porém não foi possível estimar a quantidade exata de resina que permaneceu entre as faces.

A placa de fibrocimento e os painéis de partículas, esquadrejados na mesma dimensão de $40 \mathrm{~mm}$ x $40 \mathrm{~mm}$, e contraplacados em resina, alinhados pelas faces laterais, posicionados no prato da prensa termo-hidráulica (Figura 52a), foram submetidos a uma carga de pressão constante de $1 \mathrm{MPa}$ por um período de 30 minutos em temperatura ambiente para que a reação de adesão ocorresse, testes prévios de produção levaram adotar este tempo de 
prensagem e quantidade de resina. Foi produzido um painel sanduíche como teste, com núcleo de painéis aglomerado de partículas de fibra da casca de coco verde e de madeira pinus, foi preparado com baixa densidade, quatro corpos de prova foram preparados, a amostra foi ensaiada à flexão e respondeu bem ao ensaio, indicou bom desempenho da resina e serviu de referência para a produção dos painéis sanduíche do delineamento experimental.

Figura 52 - Painéis sanduíche compostos por núcleo de painéis aglomerados de partículas de subprodutos da agroindústria e MDP comercial com faces de placa de fibrocimento após prensagem

(a)

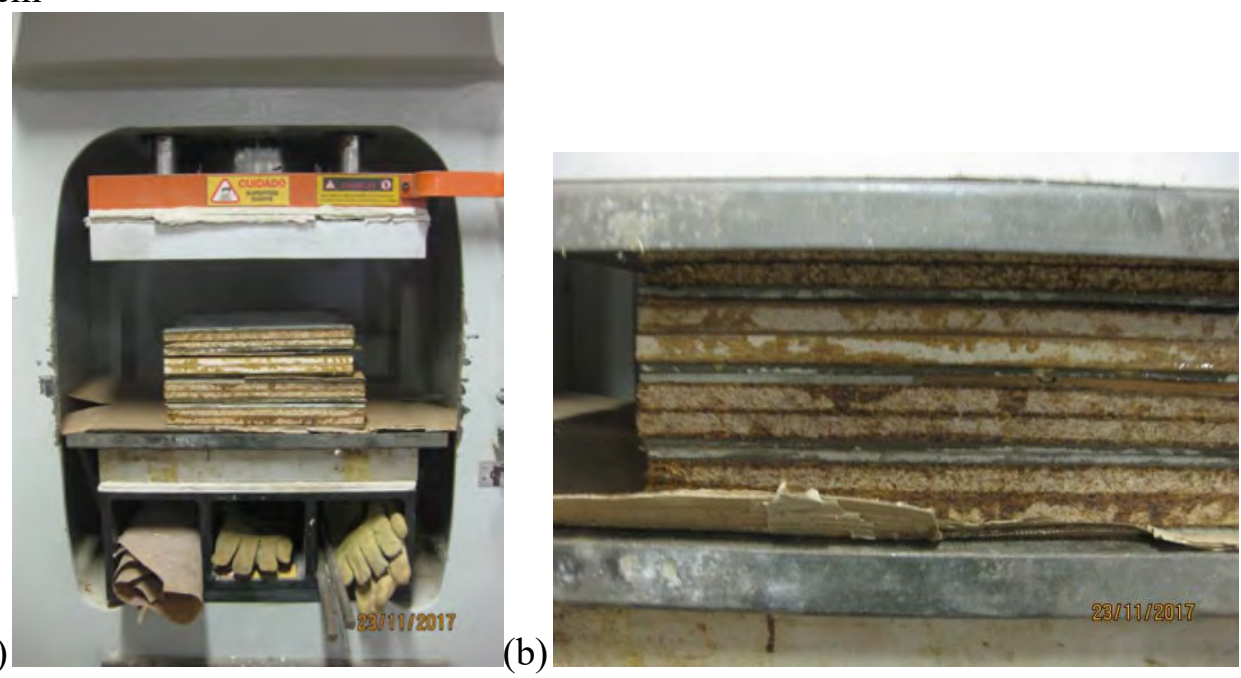

(a) Posicionamento dos painéis sanduíche (b) Detalhe da resina após prensagem Fonte: Própria autoria.

Entre os sanduíches de painéis de partículas e placas de fibrocimento e a base inferior e superior da prensa foram posicionados "folhas de papelão" para proteger os painéis e a prensa da resina que escorreria na hora da prensagem conforme (Figura 55b).

O delineamento experimental dos painéis sanduíche foi composto sobre os tratamentos dos painéis de partículas aglomeradas de subprodutos da agroindústria e do painel comercial de partículas de madeira aglomeradas de média densidade (MDP) como descrito no item 3.2.2 e resumido no (Quadro 9).

Com o delineamento experimental dos painéis de partículas (núcleos do painel sanduíche) descreveu-se o delineamento experimental para os painéis sanduíches como segue: tratamento T5 representa o painel sanduíche com núcleo de painéis aglomerado de partículas de subprodutos da agroindústria de baixa densidade (PS1-BD), o tratamento T6 painel sanduíche com núcleo de painéis aglomerado de partículas de subprodutos da agroindústria de média densidade (PS2-MD), o tratamento T7 painel sanduíche com núcleo de painéis 
aglomerado de partículas de subprodutos da agroindústria de alta densidade (PS3-AD) e tratamento T8 painel sanduíche com núcleo de painéis aglomerado comercial de partículas de madeira de média densidade (PS4-MDP). O (Quadro 12) resume em duas seções os parâmetros e variáveis de produção dos painéis sanduíche e o delineamento experimental descrito anteriormente.

Quadro 12 - Delineamento experimental para os painéis sanduíche

\begin{tabular}{|c|c|c|c|c|}
\hline \multicolumn{5}{|c|}{ Parâmetro e variáveis de produção } \\
\hline \multicolumn{2}{|c|}{ Espessura média dos painéis de partículas } & \multicolumn{3}{|c|}{$2 \times 15 \mathrm{~mm}$} \\
\hline \multicolumn{2}{|c|}{ Densidade média dos núcleos dos painéis } & \multicolumn{3}{|c|}{$359 ; 571 ; 640$ (MDP comercial) e 777} \\
\hline \multicolumn{2}{|c|}{$\begin{array}{l}\text { Espessura média das faces (placas de } \\
\text { fibrocimento) }\end{array}$} & \multicolumn{3}{|c|}{$2 \times 6 \mathrm{~mm}$} \\
\hline \multicolumn{2}{|c|}{ Densidade média das faces não saturadas } & \multicolumn{3}{|c|}{$1337 \mathrm{~kg} / \mathrm{m}^{3}$} \\
\hline \multicolumn{2}{|c|}{ Resina PU-mamona } & \multicolumn{3}{|c|}{300 gramas (50 gramas por face) } \\
\hline \multicolumn{2}{|c|}{ Pressão de laminação } & \multicolumn{3}{|c|}{$1 \mathrm{MPa}$} \\
\hline \multicolumn{2}{|c|}{ Temperatura de prensagem } & \multicolumn{3}{|c|}{ Ambiente } \\
\hline \multicolumn{2}{|c|}{ Tempo de prensagem } & \multicolumn{3}{|c|}{30 min. } \\
\hline \multicolumn{2}{|c|}{ Espessura média proposta do painel sanduíche } & \multicolumn{3}{|c|}{$42 \mathrm{~mm}$} \\
\hline \multicolumn{5}{|c|}{ Tratamento experimental } \\
\hline Tratamento & \multicolumn{2}{|l|}{ Configuração } & $\begin{array}{l}\text { Densidade média } \\
\text { dos núcleos }\left(\mathrm{kg} / \mathrm{m}^{3}\right)\end{array}$ & Adesivo \\
\hline T5: (PS1 - BD) & \multicolumn{2}{|c|}{$\begin{array}{l}2 \text { placas de fibrocimento }+2 \\
\text { painéis de } 15 \mathrm{~mm} \text { híbrido }\end{array}$} & 359 & PU-Mamona \\
\hline T6: (PS2 - MD) & \multicolumn{2}{|c|}{$\begin{array}{l}2 \text { placas de fibrocimento }+2 \\
\text { painéis de } 15 \mathrm{~mm} \text { híbrido }\end{array}$} & 571 & PU-Mamona \\
\hline T7: (PS3 - AD) & \multicolumn{2}{|c|}{$\begin{array}{l}2 \text { placas de fibrocimento }+2 \\
\text { painéis de } 15 \mathrm{~mm} \text { híbrido }\end{array}$} & 777 & PU-Mamona \\
\hline T8: (PS4 - MDP) & \multicolumn{2}{|c|}{$\begin{array}{l}2 \text { placas de fibrocimento }+2 \\
\text { painéis MDP comercial }\end{array}$} & 640 & PU-Mamona \\
\hline
\end{tabular}

Fonte: Própria autoria.

A espessura do painel sanduíche conformado atingiu o valor total aproximado de 42 mm (Figura 53a e Figura 53b), resultado da dimensão dos componentes que os compõem. As placas de fibrocimento com espessura média de $6 \mathrm{~mm}$, formadoras das faces do painel totalizaram $12 \mathrm{~mm}$, o núcleo composto da associação de dois painéis de partículas de 
aproximadamente $15 \mathrm{~mm}$ sobrepostos formaram uma camada média de $30 \mathrm{~mm}$, os quais totalizam medidas comerciais similares as pesquisadas.

Figura 53 - Perfil do painel sanduíche formado por núcleo de painel aglomerado de partículas de subprodutos da agroindústria com faces de placa de fibrocimento e espessura aproximada de um dos corpos de prova
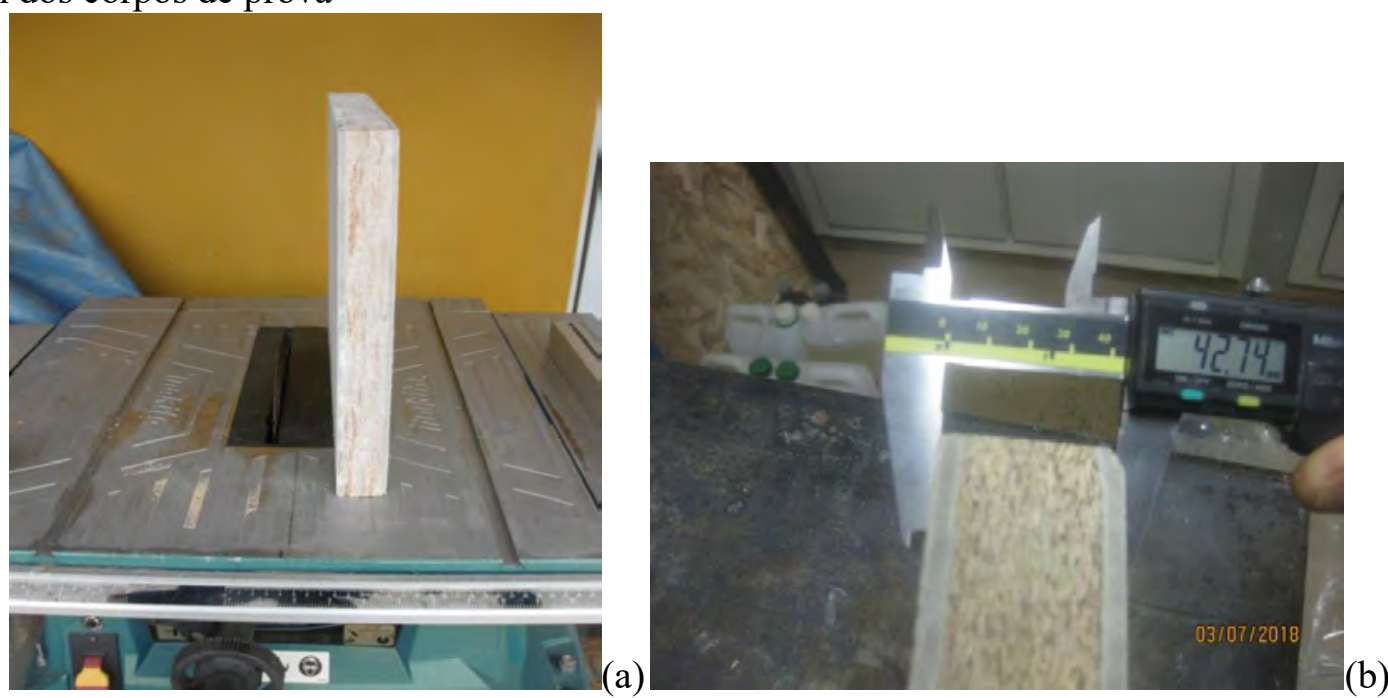

(a) Perfil do painel sanduíche de subprodutos (b) Espessura média do painel Fonte: Própria autoria.

\subsubsection{Preparação dos corpos de prova do painel sanduíche}

Para a preparação dos corpos de prova, os painéis foram esquadrejados com auxílio de uma serra elétrica de bancada com disco diamantado (Figura 47), seguindo um plano de corte e preparação de acordo com as normas referenciadas na seção 3.2.7. As amostras foram preparadas para a caracterização físico-mecânica dos painéis conforme (Quadro 13).

Quadro 13 - Planejamento de corte dos corpos de prova dos painéis sanduíche

\begin{tabular}{|l|c|c|c|}
\hline \multicolumn{3}{|c|}{ Dimensões e quantidades de corpos de prova avaliados } \\
\hline \multicolumn{1}{|c|}{ Propriedades } & Comprimento $(\mathrm{mm})$ & Largura $(\mathrm{mm})$ & Quantidade \\
\hline $\begin{array}{l}\text { Resistência de ruptura de núcleo e } \\
\text { face; e cisalhamento de núcleo na } \\
\text { flexão estática. }\end{array}$ & 200 & 75 & 16 \\
\hline
\end{tabular}

Fonte: ASTM C393/C393M-16 Standard Test Method for Core Shear Properties of Sandwich Construction by Bean Flexure. 
Os ensaios foram feitos com os corpos de prova sem condicionamento prévio conforme item 10.3 das diretrizes da norma ASTM C393/C393M - 2016 Standard Test Method for Core Shear Properties of Sandwich Construction by Bean Flexure.

\subsubsection{Caracterização física, mecânica e térmica do painel sanduíche}

Para a realização do ensaio físico seguiram-se as diretrizes da norma internacional ASTM C 271 - 1999 Standard Test Method for Density of Core Materials.

A caracterização do painel sanduíche seguiu as diretrizes da norma internacional ASTM C393/C393M - 2016 Standard Test Method for Core Shear Properties of Sandwich Construction by Bean Flexure. Os ensaios mecânicos específicos realizados nos painéis sanduíches podem conduzir a determinação de propriedades mecânicas de faces e núcleo. Na seção 5 da norma fica definido o uso e significância dos testes de caracterização mecânica possíveis de se aplicar.

Para prever a condutividade térmica do painel sanduíche foi feito um levantamento de equações analíticas que avaliam o comportamento térmico de materiais homogêneos compostos associados. Tomando os resultados obtidos nos ensaios feitos com os painéis de partículas e as placas de fibrocimento que compõem o painel sanduíche e seguindo as normas ABNT NBR 15220-4: 2005 - Desempenho térmico de edificações Parte 4: Medição da resistência térmica e da condutividade térmica pelo princípio da placa quente protegida e ABNT NBR 15220-2: 2005 - Desempenho térmico de edificações Parte 2: Métodos de cálculo da transmitância térmica, da capacidade térmica, do atraso térmico e do fator solar de elementos e componentes de edificações, foi possível estimar o comportamento térmico do conjunto.

\subsubsection{Caracterização física e mecânica do painel sanduíche}

Com o objetivo de avaliar a densidade aparente do painel sanduíche, foram preparados 16 corpos de provas (CP) com dimensões aproximadas de $42 \mathrm{~mm}$ x $75 \mathrm{~mm}$ x 200 $\mathrm{mm}, 4$ corpos de prova para cada tratamento proposto no delineamento experimental que posteriormente foram utilizados para ensaios mecânicos. Após aferidos em uma balança eletrônica digital analítica, mediram-se a espessura no ponto de intersecção das diagonais da 
face das amostras e as dimensões laterais em dois pontos paralelos distintos de cada lado determinando a largura média e finalmente a espessura para o calculo do volume de cada corpo de prova. Foram determinadas as densidades de cada amostra dos painéis de partículas por meio da equação (4).

Com o objetivo de avaliar as propriedades estruturais dos painéis sanduíche de diferentes densidades como descrito no delineamento experimental, este item conduziu testes mecânicos específicos que avaliaram o painel compósito e gerou informações sobre os elementos que o compõem. Foi realizado quatro ensaios em flexão estática para cada tratamento proposto e seguindo as diretrizes da norma ASTM C393/393M-16 Standard Test Method for Core Shear Properties of Sandwich Construction by Beam Flexure, o teste realizado foi o flexão à ruptura em três pontos.

O ensaio estático de flexão do núcleo e faces é direcionado para investigar a tensão do painel na flexão, a resistência e o módulo de cisalhamento do núcleo ou ainda a resistência à tração e compressão das faces (ALMEIDA, 2010).

Conforme a norma ASTM C393M-16, foram produzidos corpos de prova com dimensões de $75 \mathrm{~mm}$ x $200 \mathrm{~mm}$ para cada uma das diferentes densidades de núcleo préestabelecidas. Antes de iniciar o ensaio, os corpos de prova foram nomeados e medidos com um paquímetro, foram feitas três tomadas de medidas em suas dimensões como comprimento, largura e espessura em três pontos diferentes em cada seção, as medidas do comprimento e largura com precisão de $\pm 0,254 \mathrm{~mm}$ e as medidas da espessura $\pm 0,025 \mathrm{~mm}$.

Aferidas as medidas das dimensões e inseridas no software Tesc versão 1.3 interligado (unidade de aquisição de dados) com a máquina universal de ensaios mecânicos EMIC e deflectômetro para medição de pequenas deformações, cada corpo de prova foi posicionado sobre os apoios, distanciado em $150 \mathrm{~mm}$ e submetidos ao ensaio de flexão estática, após a ruptura (Figura 54b) determinou-se a força máxima aplicada e a deformação sofrida. Também se originou um arquivo txt para futuras análises de cada ensaio. Os painéis foram ensaiados com apoios em rótulas cilíndricas conforme diretrizes da norma e a carga para o ensaio em três pontos foi aplicada a meio vão conforme (Figura 54a). 
Figura 54 - Posicionamento do corpo de prova do painel sanduíche com núcleo de painéis de partículas de subprodutos da agroindústria e placas de fibrocimento na configuração de carga em três pontos e durante ensaio de flexão chegando à ruptura
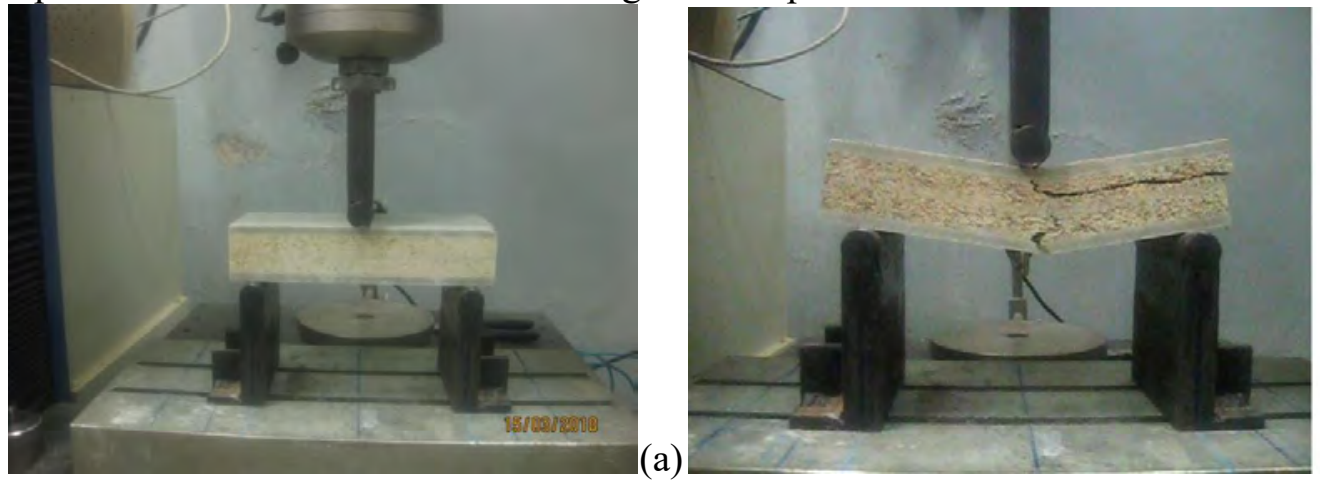

(b)

(a) Atuador aplicado no meio do vão (b) Painel sanduíche em ruptura Fonte: Próprio autor.

A máquina universal foi programada para que o fim dos testes ocorresse no intervalo entre três e seis minutos. Como a tensão de ruptura do material era desconhecida as primeiras tentativas seguiram a sugestão da norma em utilizar a velocidade do atuador em $6 \mathrm{~mm} / \mathrm{min}$. Determinaram-se os valores representativos das propriedades mecânicas do painel sanduíche no carregamento em 3 pontos aplicando as equações (18); (19) e (20) respectivamente:

$$
\begin{gathered}
\text { Fult }=\frac{\text { Pmax }}{(d+c) b}(18) \\
\sigma=\frac{\text { Pmax } X S}{2 t(d+c) b}(19) \\
\text { Fyield }(s)=\frac{\text { Pyield }}{(d+c) b}
\end{gathered}
$$

Onde:

Fult $=$ tensão máxima de cisalhamento de núcleo para carregamento em 3 pontos expresso em (MPa);

$\sigma=$ Estresse da face para carregamento em 3 pontos expresso em (MPa);

Fyield $=$ tensão de cisalhamento de núcleo para carregamento em 3 pontos onde materiais atingem escoamento (deformação) acima de 2\% expresso em (MPa); 
Pmax $=$ força máxima antes da ruptura expressa em $(\mathrm{N})$;

Pyield $=$ força estabelecida a $2 \%$ do escoamento (deformação) em $(\mathrm{N})$;

$\mathrm{t}=$ espessura nominal das faces expressa em $(\mathrm{mm})$;

$\mathrm{d}=$ espessura do sanduíche expressa em $(\mathrm{mm})$;

$\mathrm{c}=$ espessura do miolo expresso em $(\mathrm{mm})$ onde $(\mathrm{c}=\mathrm{d}-2 \mathrm{t}) \mathrm{e}$

$\mathrm{b}=$ largura do sanduíche expresso em $(\mathrm{mm})$;

$\mathrm{S}=$ distância entre apoio expresso em $(\mathrm{mm})$;

\subsubsection{Análise da condutividade e resistência térmica do painel sanduíche}

A condutividade térmica do painel sanduíche foi obtida por equações analíticas que descrevem o comportamento térmico de materiais variados. Adotaram-se os resultados obtidos nos ensaio de condutividade das placas de fibrocimento, dos painéis de partículas de madeira e dos painéis de subprodutos da agroindústria e aplicaram-se as equações recomendadas segundo as normas ABNT NBR 15220-4: 2005 - Desempenho térmico de edificações Parte 4: Medição da resistência térmica e da condutividade térmica pelo princípio da placa quente protegida e ABNT NBR 15220-2: 2005 - Desempenho térmico de edificações Parte 2: Métodos de cálculo da transmitância térmica, da capacidade térmica, do atraso térmico e do fator solar de elementos e componentes de edificações, foi possível estimar o comportamento térmico do conjunto formado por placas e painéis.

A resistência térmica de um componente com camadas homogêneas perpendiculares ao fluxo de calor é determinada pela soma das resistências térmicas das $\mathrm{n}$ camadas homogêneas (ABNT NBR 15220-2: 2005 - Desempenho térmico de edificações Parte 2, conforme equação (21):

$$
R t=R t 1+R t 2+\cdots+R t n(21)
$$

Onde:

$\mathrm{Rt}=$ resistência térmica de superfície a superfície expressa em $\left(\mathrm{m}^{2} \mathrm{~K} / \mathrm{W}\right)$;

$\mathrm{Rt} 1+\mathrm{R} t 2+\ldots+\mathrm{Rtn}=$ resistência térmica das $\mathrm{n}$ camadas homogêneas, determinadas pela equação (10) e expressas em $\left(\mathrm{m}^{2} \mathrm{~K} / \mathrm{W}\right)$. 
A resistência térmica total de um componente é determinada pela equação (22) que expressa a resistência térmica de cada camada, superfície a superfície e ambiente a ambiente:

$$
R T=R s e+R t+R s i(22)
$$

Onde:

$\mathrm{RT}=$ resistência térmica total de um componente expressa em $\left(\mathrm{m}^{2} \mathrm{~K} / \mathrm{W}\right)$;

Rse e Rsi = resistência térmica superficial externa e interna expressas em $\left(\mathrm{m}^{2} \mathrm{~K} / \mathrm{W}\right)$.

Seguindo as diretrizes da norma e com os testes em laboratório de todos os componentes formadores do painel sanduíche foi possível aplicar as fórmulas descritas anteriormente. Dessa forma estimaram-se as resistências térmicas aproximadas das amostras dos painéis sanduiches para os tratamentos propostos. Seguindo o mesmo método utilizado para os painéis de partículas e placa de fibrocimento, calculou-se condutividade dos painéis sanduíches utilizando a equação (10).

A Transmitância térmica é a quantidade de fluxo de calor que atravessa componentes de ambiente a ambiente, é o inverso da resistência total do material ou componente ensaiado, conforme equação (23):

$$
U=\frac{1}{R T}(23)
$$

Onde:

$\mathrm{U}=$ transmitância térmica expressa em $\mathrm{W} /\left(\mathrm{m}^{2} \cdot \mathrm{K}\right)$;

$\mathrm{RT}=$ resistência térmica total de um componente expressa em $\left(\mathrm{m}^{2} \mathrm{~K} / \mathrm{W}\right)$.

\subsection{Planejamento experimental}

3.3.1 Planejamento estatístico para os ensaios das amostras dos painéis de partículas de subprodutos da agroindústria e MDP

Elaborou-se um experimento estatístico de acordo com o delineamento inteiramente casualizado (DIC). A análise inferencial considerou o efeito principal em cada variável 
resposta (teor de umidade, inchamento 24 horas, densidade, resistência à tração perpendicular, resistência à flexão estática, módulo de elasticidade, e resistência ao arranque de parafuso no topo e superfície) determinando assim, se entre as repetições (corpos de prova) existia diferença estatística significativa. Para a realização dos testes foi utilizado o programa Statistical Analysis System (S.A.S versão 9.3), as variáveis foram analisadas por meio de Teste F. Posteriormente mediante a análise de variância e teste de Tukey a $5 \%$ de significância $(\mathrm{p}<0,05)$, comparou-se as médias de cada propriedade avaliada com probabilidade de $95 \%$.

Foi proposto um fator densidade com quatro níveis, classificados em baixa densidade com $350 \mathrm{~kg} / \mathrm{m}^{3}$, média densidade com $600 \mathrm{~kg} / \mathrm{m}^{3}$, alta densidade com $850 \mathrm{~kg} / \mathrm{m}^{3}$ e MDP comercial com $700 \mathrm{~kg} / \mathrm{m}^{3}$.

Para se verificar os parâmetros de produção, organizar e resumir as propriedades físicas, mecânicas e térmicas dos painéis de partículas utilizou-se da Estatística Descritiva, onde a média aritmética foi utilizada como medida de tendência central, o desvio padrão e o coeficiente de variação como medida de dispersão.

Para os resultados médios de cada ensaio físico-mecânico foram utilizadas dez unidades experimentais para cada tratamento seguindo as diretrizes da norma ABNT NBR 14810-2: 2013 - Painéis de partículas de média densidade: Requisitos e métodos de ensaio.

Para o ensaio de condutividade térmica foram preparadas oito unidades experimentais para cada tratamento seguindo as diretrizes da norma ASTM E1530-11 Evaluating the resistance to Thermal Transmission of Material by the Guarded Heat Flow Meter Technique.

\subsubsection{Planejamento estatístico para os ensaios das amostras da placa de}

\section{fibrocimento}

Para se verificar, organizar e resumir as propriedades físicas, mecânicas e térmicas das placas de fibrocimento adotou-se a Estatística Descritiva, onde a média aritmética foi utilizada como medida de tendência central, o desvio padrão e o coeficiente de variação como medida de dispersão. 
Foram utilizadas seis unidades experimentais para os ensaios físicos e mecânicos, seguindo as diretrizes da norma RILEM - Testing Methods for Fibre Reinforced CementBased Composites.

Para o ensaio de condutividade térmica foram preparados oito corpos de prova experimentais seguindo as diretrizes da norma ASTM E1530-11 - Evaluating the resistance to Thermal Transmission of Material by the Guarded Heat Flow Meter Technique.

\subsubsection{Planejamento estatístico para os ensaios das amostras do painel sanduíche}

Elaborou-se um experimento estatístico de acordo com o delineamento inteiramente casualizado (DIC). A análise inferencial considerou o efeito principal em cada variável resposta (core shear ultimate stress, core shear yield stress e facing stress) determinando assim, se entre as repetições (corpos de prova) existia diferença estatística significativa. Para a realização dos testes foi utilizado o programa Statistical Analysis System (S.A.S versão 9.3), as variáveis foram analisadas por meio de Teste F. Posteriormente mediante a análise de variância e teste de Tukey a $5 \%$ de significância $(\mathrm{p}<0,05)$, comparou-se as médias de cada propriedade avaliada com probabilidade de $95 \%$.

Foi proposto um fator densidade de núcleo com quatro níveis, classificados em baixa densidade com $359 \mathrm{~kg} / \mathrm{m}^{3}$, média densidade com $571 \mathrm{~kg} / \mathrm{m}^{3}$, alta densidade com $777 \mathrm{~kg} / \mathrm{m}^{3}$ e MDP comercial com $640 \mathrm{~kg} / \mathrm{m}^{3}$.

Para se verificar os parâmetros de produção, organizar e resumir as propriedades físicas e mecânicas e térmicas dos painéis sanduíche utilizou-se da Estatística Descritiva, onde a média aritmética foi utilizada como medida de tendência central, o desvio padrão e o coeficiente de variação como medida de dispersão.

Para os resultados médios de cada ensaio físico-mecânico foram utilizadas quatro unidades experimentais para cada tratamento seguindo a diretriz da norma ASTM C393C393M - 2016: Standard Test Method for Core Shear Properties of Sandwich Construction by Beam Flexure.

Para a avaliação da condutividade térmica utilizou-se equações analíticas que descrevem o comportamento térmico de materiais variados. Adotaram-se os resultados obtidos nos ensaio de condutividade das placas de fibrocimento, dos painéis de partículas de madeira (MDP) e dos painéis de partículas de subprodutos da agroindústria. Aplicou-se as 
equações recomendadas segundo as normas ABNT NBR 15220-4: 2005 - Desempenho térmico de edificações Parte 4: Medição da resistência térmica e da condutividade térmica pelo princípio da placa quente protegida e ABNT NBR 15220-2: 2005 - Desempenho térmico de edificações Parte 2: Métodos de cálculo da transmitância térmica, da capacidade térmica, do atraso térmico e do fator solar de elementos e componentes de edificações, assim foi possível analisar o comportamento térmico do compósito formado por placas e painéis e estimar a condutividade conjunta de placas (faces) e painéis (núcleo) de cada tratamento. 


\section{ANÁLISE DOS RESULTADOS E DISCUSSÃO}

\subsection{Resultados experimentais}

Os resultados descritos a partir do próximo item apresentam as propriedades físicas, mecânicas e térmicas de todos os componentes formadores e dos painéis sanduíche propriamente dito. Todos os tratamentos e variáveis foram descritas e analisadas estatisticamente para as considerações seguintes.

\subsection{Apresentação das propriedades físicas, mecânicas e térmicas dos painéis} aglomerado de partículas

Os quadros seguintes resumem as propriedades das amostras das matérias primas e dos painéis aglomerado de partículas e fibras experimentais de cada tratamento proposto e apresentam as seguintes medidas: (i) média aritmética das propriedades; (ii) desvio padrão (DP) e (iii) coeficiente de variação (CV). Para a análise inferencial foram avaliadas as variáveis propostas considerando o fator densidade de acordo com o item 3.3.

\subsubsection{Propriedades físicas}

Os resultados apresentados são a média dos corpos de prova de cada amostra analisada por tratamento. As tabelas seguintes (Tabela 1) e (Tabela 2) resumem as propriedades físicas das matérias primas para a produção e as propriedades físicas, mecânicas e térmicas dos painéis aglomerados de subprodutos da agroindústria (fibras da casca de coco verde e da maravalha de madeira).

\section{- Teor de umidade das partículas e fibras}

O teor de umidade médio expresso em (\%) das amostras das fibras da casca de coco verde, Cocos nucifera e das partículas de madeira pinus, Pinus sp, (Tabela 1), foram analisadas para se verificar o excesso de umidade, segundo revisão bibliográfica o teor de umidade das matérias primas é umas das variáveis que podem afetar as propriedades mecânicas dos painéis, conforme exposto por (BONILLA BUENO, 2015). Em seu trabalho o 
autor tratou a matéria prima utilizada na produção de painéis multicamadas de bagaço de cana e fibras da casca de coco verde em um teor de umidade entre $8 \%$ e $10 \%$.

Tabela 1 - Teor de umidade média das matérias primas para produção dos painéis de partículas

\begin{tabular}{lcccc}
\hline \multicolumn{1}{c}{ Matéria prima } & *Requisito & $\begin{array}{c}\text { Teor de umidade } \\
\text { médio (\%) }\end{array}$ & DP (\%) & CV (\%) \\
\hline Fibra da casca de coco verde & $5 \%-13 \%$ & $\pm \mathbf{1 2 , 0 6}$ & 1,06 & 8,82 \\
Partícula de madeira & $5 \%-13 \%$ & $\pm \mathbf{2 , 7 8}$ & 0,19 & 6,91 \\
\hline
\end{tabular}

Nota: *Requisito adotado de acordo com revisão bibliográfica

Fonte: Próprio autor.

Segundo Cravo (2013) a redução do teor de umidade antes do processo de produção pode evitar a possibilidade de expansão dos painéis aglomerados por evaporação da água impregnada nas matérias primas.

\section{- Densidade real das partículas e fibras}

A densidade média real das amostras de fibras da casca de coco verde, Cocos nucifera, e das partículas de madeira pinus, Pinus sp apresentaram valores aproximados (Tabela 2).

Tabela 2 - Densidade real média das matérias primas para produção dos painéis de partículas

\begin{tabular}{lccc}
\hline \multicolumn{1}{c}{ Matéria prima } & $\begin{array}{c}\text { Densidade real média } \\
\left(\mathbf{g} / \mathbf{c m}^{\mathbf{3}}\right)\end{array}$ & DP $\left(\mathbf{g} / \mathbf{c m}^{3}\right)$ & CV (\%) \\
\hline Fibra da casca de coco verde & $\mathbf{1 , 4 0}$ & 0,014 & 1,062 \\
Partícula de madeira & $\mathbf{1 , 3 4}$ & 0,009 & 0,688 \\
\hline
\end{tabular}

Fonte: Próprio autor.

No estudo de Bonilla Bueno (2015) o valor médio da densidade da fibra da casca de coco verde resultou em $1420 \mathrm{~kg} / \mathrm{m}^{3}$, o autor cita valores entre $1400 \mathrm{~kg} / \mathrm{m}^{3}$ (PEREIRA, 2012) e $1300 \mathrm{~kg} / \mathrm{m}^{3}$ (FIORELLI et al., 2014). O autor apresentou outros valores de densidades, das 
fibras da madeira pinus, Pinus spp, variando entre $800 \mathrm{~kg} / \mathrm{m}^{3}$ (FIORELLI et al., 2014) e 900 $\mathrm{kg} / \mathrm{m}^{3}$ de acordo com (BERTOLINI, 2011).

Fiorelli (2013) apresentou em seu trabalho resultado médio para a densidade real das partículas de Pinus spp em $0,82 \mathrm{~g} / \mathrm{cm}^{3}$. Em outro trabalho (FIORELLI et al. 2015) encontraram resultados médios de $1,24 \mathrm{~g} / \mathrm{cm}^{3}$ de densidade real para as partículas de Pinus spp e $1,30 \mathrm{~g} / \mathrm{cm}^{3}$ para as fibras da casca de coco verde.

Diante dos valores obtidos para a densidade real das matérias primas e conforme estudo de (BONILLA BUENO, 2015), que analisou a densidade real das fibras da casca de coco verde e expôs em seu trabalho o potencial dos subprodutos da agroindústria para a produção de painéis de partículas, obteve resultado para a densidade das fibras superior a da madeira pinus utilizada na indústria de aglomerados. Assim os resultados obtidos para este experimento se apresentaram satisfatórios e similares a outras pesquisas acadêmicas (Tabela 2).

Os resultados seguintes resumem as propriedades físicas, mecânicas e térmicas dos painéis de partículas aglomerados de subprodutos da agroindústria (fibras da casca de coco verde e da maravalha de madeira pinus) e do painel MDP comercial. As propriedades foram analisadas em um único grupo cruzando todos os tratamentos e a análise inferencial resultou em valores médios avaliando a diferença estatística significativa $(\mathrm{p}<0,05)$. O resultado obtido pelo teste Tukey apresenta os grupos das médias de cada tratamento. Para todas as tabelas do agrupamento de Tukey, as médias seguidas das mesmas letras não apresentaram diferença estatística significativa $(\mathrm{p}>0,05)$.

\section{- Densidade aparente das amostras dos painéis de partículas homogêneas} aglomerados

A Tabela 3 apresenta as densidades médias de cada tratamento experimental e as análises estatísticas das amostras dos painéis de partículas e fibras e do painel comercial MDP. A amostra do painel de partícula aglomerada de subprodutos da agroindústria de baixa densidade tratamento NS1-BD atendeu a faixa estabelecida pela norma internacional ANSI A208.1 - 1999 Particleboard, onde os painéis não devem ultrapassar os $640 \mathrm{~kg} / \mathrm{m}^{3}$.

Da mesma forma as amostras do painel de média densidade de subprodutos da agroindústria tratamento NS2-MD e do painel comercial de partículas de madeira MDP tratamento NS4-MDP resultaram em densidades que atenderam aos requisitos da norma 
ABNT NBR 14810-2: 2013 - Painéis de partículas de média densidade: Requisitos e métodos de ensaio, faixa que varia entre $551 \mathrm{~kg} / \mathrm{m}^{3}$ e $750 \mathrm{~kg} / \mathrm{m}^{3}$. O tratamento NS4-MDP atingiu a faixa inicial para o requisito da norma internacional ANSI A208.1 - 1999 que estabelece intervalo entre $640 \mathrm{~kg} / \mathrm{m}^{3}$ e $800 \mathrm{~kg} / \mathrm{m}^{3}$.

O resultado médio da amostra do tratamento NS3-AD não ultrapassou a faixa estabelecida pela norma internacional que fica acima de $800 \mathrm{~kg} / \mathrm{m}^{3}$. Observa-se que os painéis produzidos apresentaram densidades próximas as delineadas para o experimento com um distanciamento maior para o tratamento NS3-AD painel de partícula aglomerada de subprodutos da agroindústria de alta densidade com um desvio padrão de 45,03 kg/m³.

Tabela 3 - Densidade média dos painéis aglomerado de partículas e fibras e MDP comercial

\begin{tabular}{lcccc}
\hline $\begin{array}{l}\text { Tratamento } \\
\text { proposto }\end{array}$ & $\begin{array}{c}\text { Agrupamento } \\
\text { de Tukey }\end{array}$ & $\begin{array}{c}\text { Densidade aparente } \\
\text { média }\left(\mathbf{k g} / \mathbf{m}^{3}\right)\end{array}$ & $\begin{array}{c}\text { Desvio Padrão } \\
\left(\mathbf{k g} / \mathbf{m}^{3}\right)\end{array}$ & CV(\%) \\
\hline (NS1-BD) & $\mathbf{D}$ & $\mathbf{3 5 9}$ & 20,18 & 5,618 \\
(NS2-MD) & $\mathbf{C}$ & $\mathbf{5 7 1}$ & 18,22 & 3,191 \\
(NS3-AD) & $\mathbf{A}$ & $\mathbf{7 7 7}$ & 45,03 & 5,799 \\
(NS4-MDP) & $\mathbf{B}$ & $\mathbf{6 4 0}$ & 17,34 & 2,710 \\
\hline
\end{tabular}

Fonte: Próprio autor.

A propriedade física resultou em valores de densidades média dos painéis com diferença estatística significativa $(p<0,05)$ (Tabela 3$)$ e o fato da dispersão se apresentar baixa, conforme Gráfico 1, em relação às médias das densidades de cada tratamento, pode indicar confiabilidade dos parâmetros e variáveis adotadas no processo de produção dos painéis de partículas de subprodutos da agroindústria de acordo com (BONILLA BUENO, 2015). Vale acrescentar que os coeficientes de variação de cada tratamento resultaram abaixo dos $10 \%$, o que indica homogeneidade das amostras e baixa dispersão de valores (SILVA et al., 2008). 
Gráfico 1 - Medianas e dispersões de resultados de todos os tratamentos experimentais para os ensaios de densidade das amostras dos painéis aglomerado de partículas e fibras e MDP comercial

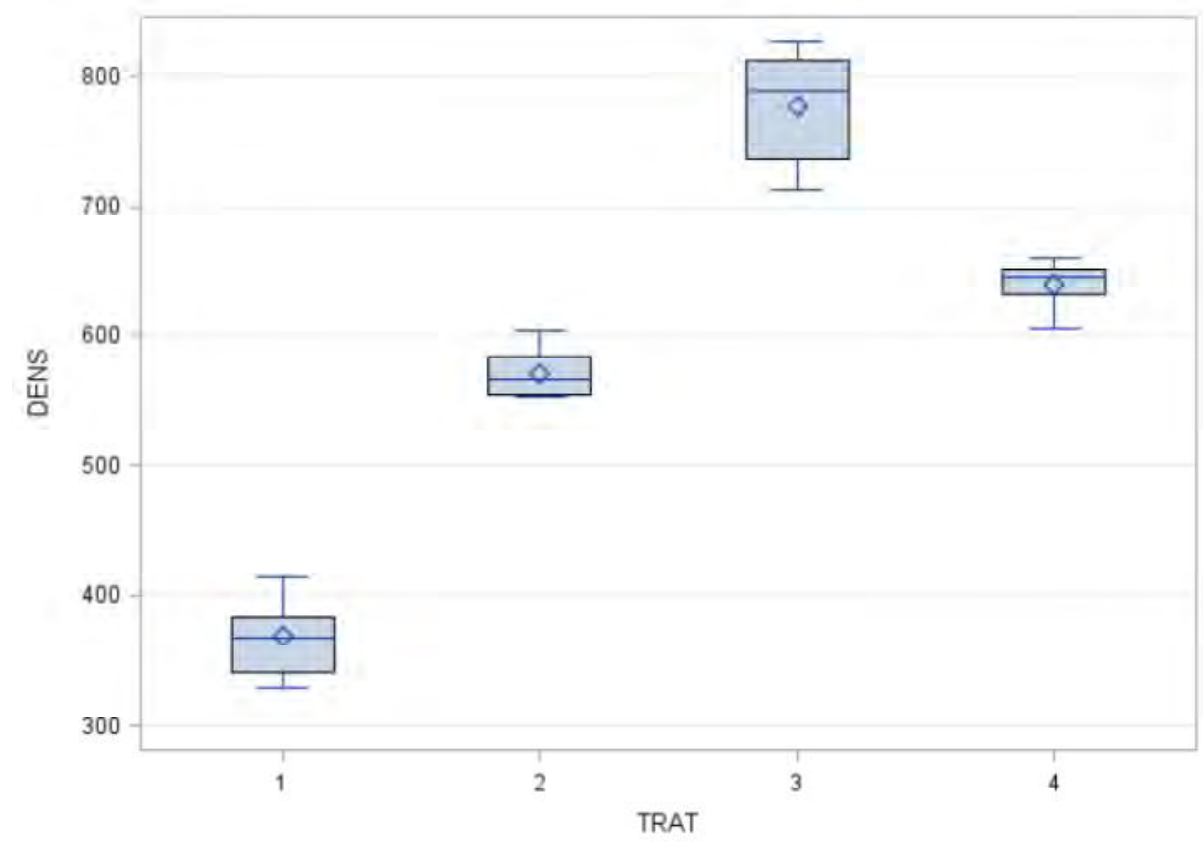

Fonte: Próprio autor.

\section{- Teor de umidade das amostras dos painéis de partículas homogêneas}

Os resultados obtidos para o teor de umidade atenderam os requisitos da norma ABNT NBR 14810-2: 2013 - Painéis de partículas de média densidade: Requisitos e métodos de ensaio (Tabela 4). O resultado obtido pelo teste Tukey apresentou os grupos das médias de cada tratamento e resultaram em valores de teor de umidade sem diferença estatística significativa $(\mathrm{p}>0,05)$ (Tabela 4).

Colli et al. (2009) produziram painéis com densidade aproximada de $360 \mathrm{~kg} / \mathrm{m}^{3}$, fabricados com 30\% de fibra de coco verde, Cocus nucifera $L$., e $70 \%$ de partículas de madeira Paricá, Schyzolobium amazonicum Huber ex. Ducke, obtiveram resultados para teor de umidade médio de $14 \%$ com porcentagem de adesivo ureia-formaldeído sobre a massa de matéria prima variando entre $6 \%$ e $8 \%$. 
Tabela 4 - Teor de umidade média dos painéis de partículas e fibras e MDP comercial

\begin{tabular}{lccccc}
\hline $\begin{array}{l}\text { Requisito NBR } \\
\text { 14810-2: 2013 }\end{array}$ & Tratamento & $\begin{array}{c}\text { Agrupamento } \\
\text { de Tukey }\end{array}$ & $\begin{array}{c}\text { Teor de } \\
\text { umidade médio } \\
\mathbf{( \% )}\end{array}$ & $\begin{array}{c}\text { Desvio } \\
\text { Padrão (\%) }\end{array}$ & CV(\%) \\
\hline (NA) & (NS1-BD) & $\mathbf{A}$ & $\mathbf{9 , 8 9}$ & 3,357 & 33,84 \\
$\mathbf{5 \% - 1 3 \%}$ & $\mathbf{( N S 2 - M D ) ~}$ & $\mathbf{A}$ & $\mathbf{8 , 0 8}$ & 1,785 & 22,08 \\
(NA) & (NS3-AD) & $\mathbf{A}$ & $\mathbf{8 , 3 9}$ & 2,018 & 24,05 \\
$\mathbf{5 \% - 1 3 \%}$ & $\mathbf{( N S 4 - M D P )}$ & $\mathbf{A}$ & $\mathbf{7 , 8 5}$ & 0,124 & 1,58 \\
\hline
\end{tabular}

Nota: $*(N A)=$ Não se aplica

Fonte: Próprio autor.

A maior medida de dispersão foi apresentada pelo tratamento NS1-BD. Os valores de CV (\%) para os tratamentos NS2-MD e NS3-AD demonstrou homogeneidade média das amostras e para o tratamento NS1-BD amostras heterogêneas (SILVA et al., 2008). No Gráfico 2 nota-se uma maior dispersão nos tratamentos NS1-BD e NS3-AD; o tratamento NS2-MD apresentou outliers entre os extremos apesar da média homogeneidade do coeficiente de variação. Os resultados indicam que a variação de densidades dos painéis de partículas e fibras não influenciou na propriedade avaliada.

Gráfico 2 - Medianas e dispersões de resultados de todos os tratamentos experimentais para os ensaios de teor de umidade das amostras dos painéis aglomerado de partículas e fibras e MDP comercial

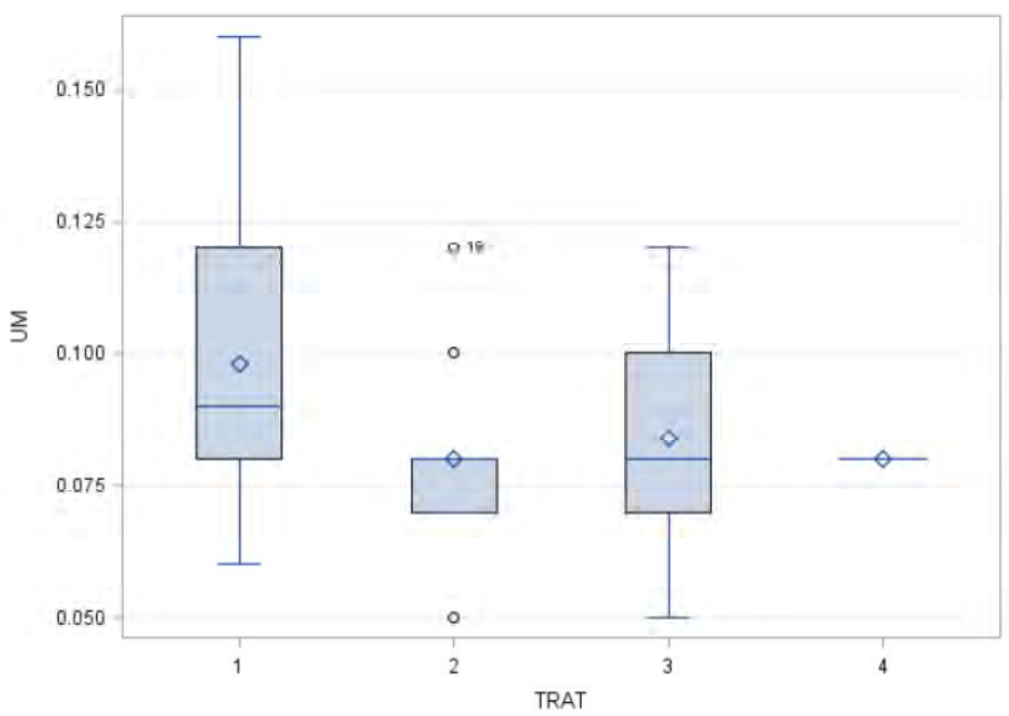

Fonte: Próprio autor. 


\section{- Inchamento médio da espessura das amostras dos painéis de partículas homogêneas}

Os resultados dos ensaios obtidos para os tratamentos experimentais propostos, com exceção do tratamento NS4-MDP, atenderam aos requisitos da norma ABNT NBR 14810-2: 2013 - Painéis de partículas de média densidade: Requisitos e métodos de ensaio. A (Tabela 5) resume as análises estatísticas da propriedade para os tratamentos experimentais e indica a homogeneidade dos resultados pelos valores de dispersão.

Tabela 5 - Inchamento médio da espessura dos painéis de partículas e fibras e MDP comercial

\begin{tabular}{lccccc}
\hline \begin{tabular}{c} 
Requisito \\
NBR 14810-2: \\
\multicolumn{2}{c}{ Trat3 }
\end{tabular} & $\begin{array}{c}\text { Agrupamento } \\
\text { de Tukey }\end{array}$ & $\begin{array}{c}\text { Inchamento médio } \\
\text { da espessura (\%) }\end{array}$ & $\begin{array}{c}\text { Desvio } \\
\text { Padrão (\%) }\end{array}$ & CV(\%) \\
\hline (NA) & (NS1-BD) & $\mathbf{D}$ & $\mathbf{1 0 , 8 8}$ & 1,676 & 15,40 \\
Máx.18\% & (NS2-MD) & $\mathbf{C}$ & $\mathbf{1 4 , 5 7}$ & 1,039 & 7,14 \\
$(\mathrm{NA})$ & (NS3-AD) & $\mathbf{B}$ & $\mathbf{1 7 , 5 6}$ & 1,354 & 7,71 \\
Máx.18\% & (NS4-MDP) & $\mathbf{A}$ & $\mathbf{2 4 , 3 2}$ & 1,171 & 4,82 \\
\hline
\end{tabular}

Nota: $*(N A)=$ Não se aplica

Fonte: Próprio autor.

O tratamento NS3-AD apresentou o maior valor médio para o ensaio de inchamento da espessura em 24 horas entre os painéis de partículas aglomeradas de subprodutos da agroindústria, próximo ao limite estabelecido pela norma ABNT NBR 14810-2: 2013. O tratamento NS4-MDP apresentou a maior média entre as amostras.

O tratamento NS1-BD com densidade igual a $359 \mathrm{~kg} / \mathrm{m}^{3}$ apresentou inchamento da espessura em 24 horas de 10,88\%, resultou no menor valor entre os tratamentos.

Colli et al. (2009) produziram painéis com densidade aproximada de $360 \mathrm{~kg} / \mathrm{m}^{3}$, fabricados com 30\% de fibra de coco verde, Cocus nucifera L., e $70 \%$ de partículas de madeira Paricá, Schyzolobium amazonicum Huber ex. Ducke, obtiveram resultados para inchamento da espessura em 24 horas de 10,46 \%. 
Passos (2005) avaliou oito tratamentos de painéis de partículas de madeira de Pinus elliotti e fibra da casca de coco verde, Cocus nucifera, com densidade média de $0,65 \mathrm{~g} / \mathrm{cm}^{3}$, um dos tratamentos com $30 \%$ de fibras da casca de coco verde e $70 \%$ de partículas madeira apresentou resultados de $22 \%$ e $18 \%$ para inchamento em espessura em 24 horas, os valores são referentes a painéis produzidos com $6 \%$ e $8 \%$ de resina respectivamente.

Segundo Cravo (2013) a variação de densidade pode causar alteração na proporção de espaços vazios da estrutura dos painéis de partículas, porém afirma que a massa específica isoladamente não é um parâmetro adequado para prever a variação de porcentagem do inchamento da espessura em 24 horas. Considerando os resultados deste experimento, a afirmação do autor é relevante, pois o painel de menor densidade de subprodutos da agroindústria apresentou o menor valor para inchamento e o painel comercial de partículas de madeira MDP de média densidade o maior valor (Tabela 5).

Fiorelli et al. (2015) testaram painéis de partículas monocamadas fabricados com resíduos de madeira e fibra de coco verde em substituição a madeira (nas proporções de $0 \%$, $25 \%, 50 \%, 75 \%$ e $100 \%$ ), utilizaram resina poliuretana bicomponente derivada de mamona em $10 \%$ sobre a massa das partículas. Os resultados médios para inchamento da espessura em 2 horas e para o painel produzido com densidade aproximada de $0,80 \mathrm{~g} / \mathrm{cm}^{3}$ foi de $12,37 \%$, $18,10 \%, 14,28 \%, 23,08 \%$ e $6,92 \%$ respectivamente, apresentaram os menores valores para a composição $100 \%$ de fibra da casca de coco verde, porém nota-se que a inclusão de fibras da casca de coco verde nas partículas de madeira aumentou o inchamento em 2 horas.

Brito et al. (2004) experimentaram painéis variando entre $0,58 \mathrm{~g} / \mathrm{cm}^{3}$ e $0,73 \mathrm{~g} / \mathrm{cm}^{3} \mathrm{de}$ densidade e tratamentos com fibra da casca de coco verde em substituição a madeira nas proporções de $0 \%, 10 \%, 20 \%$ e $30 \%$, utilizaram adesivo ureia-formaldeído nas porcentagens de $6 \%$ e $8 \%$ obtiveram resultado para inchamento em 24 horas iguais a $57 \%$ e $43 \% ; 35 \%$ e $18 \% ; 20 \%$ e $17 \% ; 20 \%$ e $18 \%$ respectivamente, neste trabalho o aumento de fibras da casca de coco verde contribuiu para a redução do inchamento em 24 horas.

O resultado obtido pelo teste Tukey apresentou os grupos das médias de cada tratamento que resultaram em valores de inchamento médio em espessura em 24 horas com diferença estatística significativa $(\mathrm{p}<0,05)$ (Tabela 5). No Gráfico 3 nota-se a baixa dispersão para todos os tratamentos, mesmo para o tratamento (NS4-MDP) que resultou num inchamento a cima do requisito máximo da norma ABNT NBR 14810-2: 2013. 
Gráfico 3 - Medianas e dispersões de resultados de todos os tratamentos experimentais para os ensaios de inchamento em espessura das amostras dos painéis aglomerado de partículas e fibras e MDP comercial

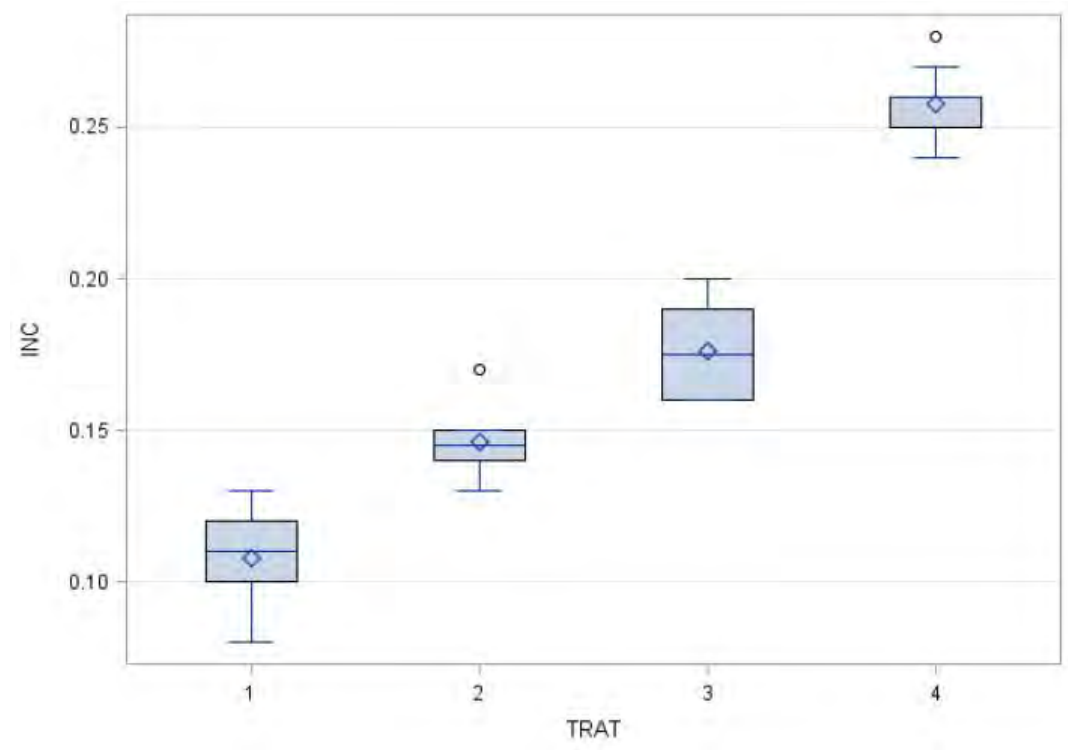

Fonte:

Próprio autor.

\subsubsection{Considerações sobre as propriedades físicas}

Diante dos valores obtidos para a densidade real das matérias primas (Tabela 2) e conforme estudo de Bonilla Bueno (2015), que avaliou a porcentagem de celulose e a densidade real das fibras da casca de coco verde e onde expôs a importância da densidade e o potencial da matéria prima para a produção de painéis de partículas, se conclui que os resultados obtidos para esta propriedade podem ser considerados satisfatórios, visto que a densidade das fibras e partículas se apresentaram superiores a da madeira pinus utilizada na indústria para o mesmo fim.

Os valores de densidade média dos painéis apresentaram diferença estatística significativa e o fato da dispersão se apresentar baixa em relação às médias das densidades de cada tratamento, pode indicar confiabilidade dos parâmetros e variáveis adotadas no processo de produção dos painéis aglomerados de partículas de subprodutos da agroindústria de acordo com (BONILLA BUENO, 2015).

Segundo Cravo (2013) a variação de densidade pode causar alteração na proporção de espaços vazios da estrutura dos painéis de partículas, porém afirma que a massa específica 
isoladamente não é um parâmetro adequado para prever a variação de porcentagem do inchamento da espessura em 24 horas.

\subsubsection{Propriedades mecânicas}

- Ensaios de flexão estática: MOR (Módulo de resistência à flexão estática) e MOE (Módulo de elasticidade)

Determinaram-se os valores de módulo de ruptura (MOR) e módulo de elasticidade (MOE) na flexão estática conforme diretrizes da norma ABNT NBR 14810-2: 2013 - Painéis de partículas de média densidade: Requisitos e métodos de ensaio. Para os resultados dos ensaios mecânicos observaram-se os requisitos mínimos da norma nacional ABNT NBR 14810-2: 2013 e internacional ANSI A208.1 - 1999 Particleboard apresentados na (Tabela 6).

Tabela 6 - MOR e MOE médio dos painéis de partículas e fibras e MDP comercial

Módulo de ruptura (MOR)

\begin{tabular}{|c|c|c|c|c|c|c|}
\hline $\begin{array}{c}\text { Requisitos } \\
\text { NBR 14810- } \\
\text { 2: } 2013\end{array}$ & $\begin{array}{c}\text { Requisitos } \\
\begin{array}{c}\text { ANSI A208.1 } \\
-1999\end{array}\end{array}$ & Tratamento & $\begin{array}{c}\text { Agrupamento } \\
\text { de Tukey }\end{array}$ & $\begin{array}{c}\text { MOR } \\
\left(\mathbf{N} / \mathbf{m m}^{2}\right)\end{array}$ & $\begin{array}{c}\text { Desvio Padrão } \\
\left(\mathbf{N} / \mathbf{m m}^{2}\right)\end{array}$ & CV (\%) \\
\hline$\overline{(\mathrm{NA})}$ & 3,00 & (NS1-BD) & $\mathrm{C}$ & 3,10 & 0,47 & 15,15 \\
\hline 11,00 & 11,00 & (NS2-MD) & B & 12,31 & 1,10 & 8,9 \\
\hline (NA) & 16,50 & (NS3-AD) & $\mathbf{A}$ & 22,33 & 4,58 & 20,5 \\
\hline 11,00 & 11,00 & (NS4-MDP) & B & 13,54 & 0,649 & 4,79 \\
\hline
\end{tabular}

Módulo de elasticidade (MOE)

\begin{tabular}{|c|c|c|c|c|c|c|}
\hline $\begin{array}{c}\text { Requisitos } \\
\text { NBR 14810- } \\
\text { 2: } 2013\end{array}$ & $\begin{array}{c}\text { Requisitos } \\
\text { ANSI A208.1 } \\
\quad-1999\end{array}$ & Tratamento & $\begin{array}{c}\text { Agrupamento } \\
\text { de Tukey }\end{array}$ & $\begin{array}{c}\text { MOE } \\
\left(\mathrm{N} / \mathbf{m m}^{2}\right)\end{array}$ & $\begin{array}{l}\text { Desvio Padrão } \\
\qquad\left(\mathbf{N} / \mathbf{m m}^{2}\right)\end{array}$ & CV (\%) \\
\hline$\overline{(\mathrm{NA})}$ & 550 & (NS1-BD) & $\mathrm{C}$ & 333 & 54,25 & 16,29 \\
\hline 1600 & 1725 & (NS2-MD) & B & 1403 & 187,60 & 13,33 \\
\hline (NA) & 2400 & (NS3-AD) & $\mathbf{A}$ & 2602 & 464,43 & 17,85 \\
\hline 1600 & 1725 & (NS4-MDP) & $\mathbf{A}$ & 2552 & 125,19 & 4,91 \\
\hline
\end{tabular}

Nota: $*(N A)=$ Não se aplica

Fonte: Próprio autor. 
Os gráficos seguintes representam a média dos ensaios de flexão estática de cada tratamento do experimento, para este propósito foram tomados aleatoriamente os resultados de seis corpos de prova dos dez testados. Foi proposto com os gráficos representar a curva típica do comportamento das amostras ensaiadas na flexão estática, onde se pode observar a aproximação com as médias das tensões de cada tratamento (Figura 55).

Figura 55 - Curvas de tensão e deformação específica representativos da média de cada tratamento experimental dos painéis de partículas aglomerados.

(a)
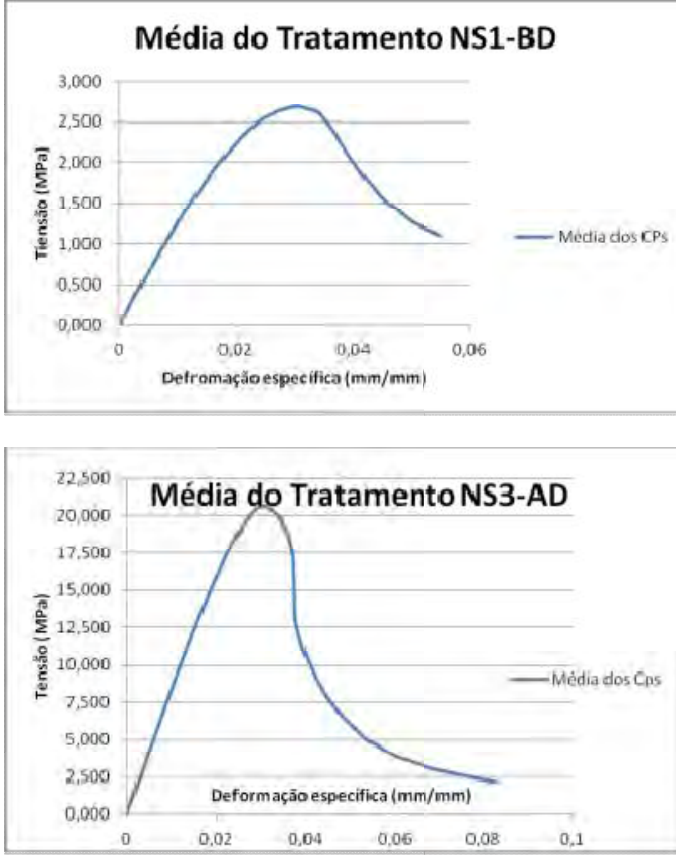

(b)
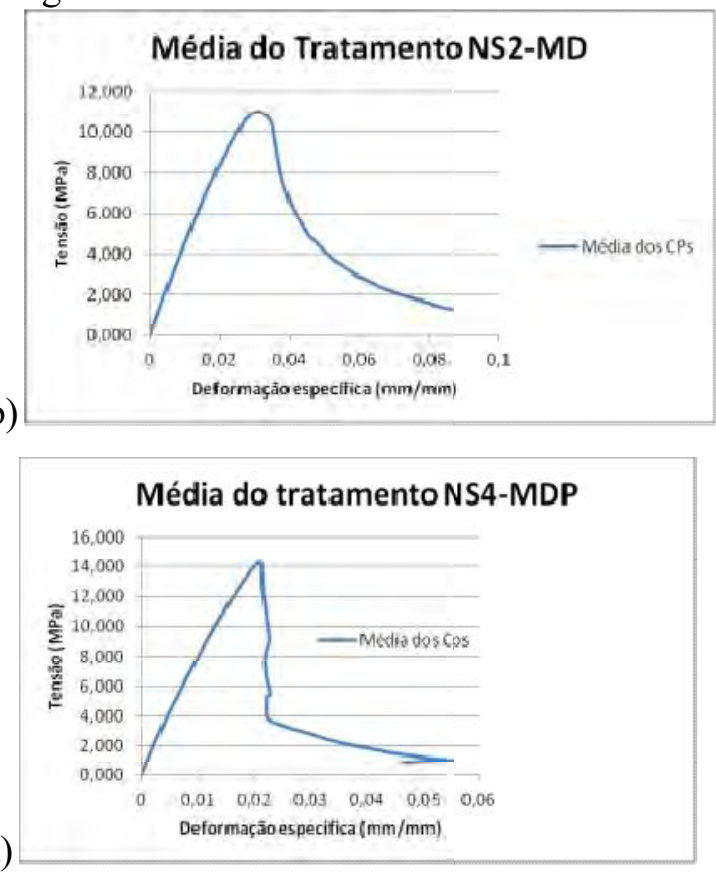

(a) Amostragem de baixa densidade. (b) Amostragem de média densidade. (c) Amostragem de alta densidade. (d) Amostragem de média densidade (MDP Comercial).

Fonte: Própria autoria.

Com relação à propriedade (MOR) todos os tratamentos atenderam aos requisitos da norma nacional e internacional. Os tratamentos NS2-MD e NS4-MDP apresentaram valores similares sem diferença estatística significativa $(\mathrm{p}>0,05)$, o resultado pode indicar que a substituição da madeira pela fibra da casca de coco verde para esta propriedade não alterou significantemente a característica do painel, porém demonstrou o potencial de aplicação das fibras e partículas de subprodutos da agroindústria como matéria prima para a produção de painéis aglomerados. Vale ressaltar que o aumento da densidade alterou as características mecânicas. 
Para a propriedade (MOE) somente os tratamentos NS3-AD e NS4-MDP atenderam os requisitos da norma nacional e internacional. Vale observar que o tratamento NS4-MDP apesar de se apresentar com média densidade atendeu o requisito mínimo estabelecido para painéis de alta densidade, bem superior ao tratamento NS2-MD que não atendeu ao requisito para painéis de média densidade. $\mathrm{O}$ fato de o MDP atender ao requisito da norma pode indicar uma melhor aglomeração das partículas de madeira ou que apresentaram maior resistência e elasticidade (Cravo, 2013). Conforme exposto pelo autor as fibras da casca de coco verde junto com o aumento da densidade podem ter melhorado as características das amostras para a propriedade MOE.

Passos (2005) testou painéis de partículas de madeira de Pinus elliottii e fibra da casca de coco verde, Cocus nucifera, com densidade média de $0,65 \mathrm{~g} / \mathrm{cm}^{3}$, um dos tratamentos com $30 \%$ de fibras da casca de coco verde e $70 \%$ de partículas madeira apresentou resultados de 15,5 MPa e 13,0 MPa para (MOR) e $1602 \mathrm{MPa}$ e $1277 \mathrm{MPa}$ para (MOE), os valores são referentes a painéis produzidos com $6 \%$ e $8 \%$ de resina respectivamente.

Fiorelli et al. (2015), para painéis de partículas monocamadas fabricados com resíduos de madeira e fibra de coco verde em substituição a madeira na proporção de $75 \%$ e $25 \%$ respectivamente e com densidade aproximada de $0,80 \mathrm{~g} / \mathrm{cm}^{3}$, obtiveram resultados médios iguais a 25,85 MPa para (MOR) e $2274 \mathrm{MPa}$ para (MOE). Os autores concluíram que a inclusão de fibra da casca de coco verde na produção de painéis proporcionou um aumento no (MOR) e uma redução no (MOE).

Colli et al. (2009) produziram painéis com densidade aproximada de $360 \mathrm{~kg} / \mathrm{m}^{3}$, fabricados com $30 \%$ de fibra de coco verde, Cocus nucifera L., e $70 \%$ de partículas de madeira Paricá, Schyzolobium amazonicum Huber ex. Ducke, obtiveram resultados em 4,46 MPa para (MOR) e 258,60 MPa para (MOE).

Brito et al. (2004) experimentaram painéis variando entre $0,58 \mathrm{~g} / \mathrm{cm}^{3}$ e $0,73 \mathrm{~g} / \mathrm{cm}^{3} \mathrm{de}$ densidade e tratamentos com fibra da casca de coco verde em substituição a madeira nas proporções de $0 \%, 10 \%, 20 \%$ e $30 \%$, utilizaram adesivo ureia-formaldeído nas porcentagens de $6 \%$ e $8 \%$ obtiveram resultados médios para (MOR) iguais a 2,23 $\mathrm{MPa}$ e 2,37 $\mathrm{MPa} ; 1,32$ $\mathrm{MPa}$ e 1,87 MPa; $1,46 \mathrm{MPa}$ e 1,88 $\mathrm{MPa}$ e 1,58 MPa e 1,33 MPa respectivamente. O autores concluíram que a inclusão de fibras de casca de coco verde na produção de painéis não proporcionou diferença estatística significativa quando comparados com os produzidos com $100 \%$ de pinus. 
O tratamento NS3-AD apresentou o maior valor de dispersão o que demonstrou média homogeneidade da amostra conforme exposto por (SILVA et al., 2008) e observado no Gráfico 4. Considerando que o aumento da densidade influencia na propriedade mecânica o coeficiente de variação pode indicar um adensamento ou distribuição desigual de partículas e fibras durante a produção, o que pode proporcionar espaços vazios e aglomeração de resina em regiões do painel e por consequência na amostra ensaiada (BONILLA BUENO, 2015).

Gráfico 4 - Medianas e dispersões de resultados de todos os tratamentos experimentais para os ensaios de MOR das amostras dos painéis aglomerado de partículas e fibras e MDP comercial

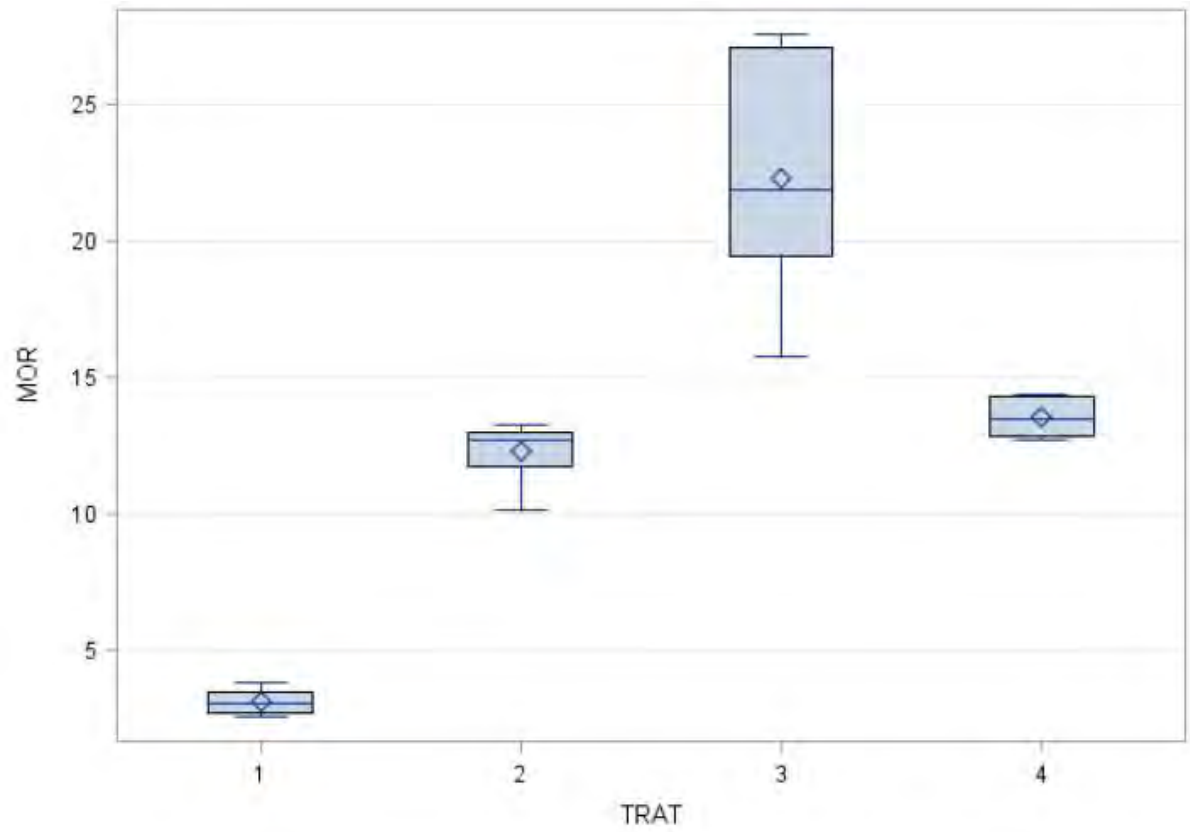

Fonte: Próprio autor.

Para o (MOE) os tratamentos NS1-BD e NS2-MD apresentaram diferença estatística significativa $(\mathrm{p}<0,05)$ entre si e entre os tratamentos NS3-AD e NS4-MDP, o que não ocorreu entre os mesmos. Conforme Gráfico 5 o tratamento NS3-AD apresentou o maior valor de dispersão. 
Gráfico 5 - Medianas e dispersões de resultados de todos os tratamentos experimentais para os ensaios de MOE das amostras dos painéis aglomerado de partículas e fibras e MDP comercial

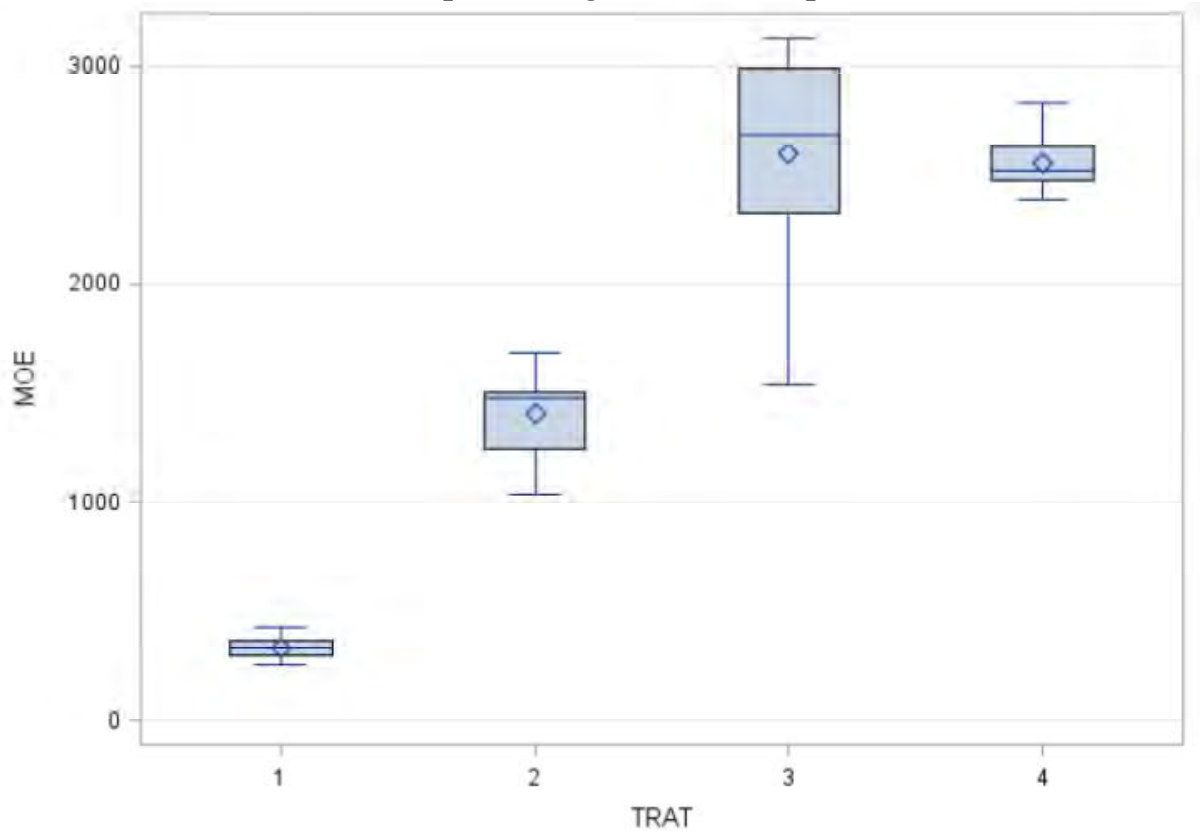

Fonte: Próprio autor.

\section{- Resistência à tração perpendicular}

Os resultados obtidos nos ensaios de tração perpendicular atenderam os requisitos da norma ABNT NBR 14810-2: 2013 - Painéis de partículas de média densidade: Requisitos e métodos de ensaio e da norma internacional ANSI A208.1 - 1999 Particleboard. A (Tabela 7) resume a análise da propriedade obtida.

Tabela 7 - Resistência á tração perpendicular dos painéis de partículas e fibras e MDP comercial

\begin{tabular}{|c|c|c|c|c|c|c|}
\hline $\begin{array}{l}\text { Requisito } \\
\text { NBR 14810- } \\
\text { 2: } 2013\end{array}$ & $\begin{array}{c}\text { ANSI } \\
\text { A208.1 - } \\
1999\end{array}$ & Tratamento & $\begin{array}{c}\text { Agrupamento } \\
\text { de Tukey }\end{array}$ & $\begin{array}{c}\text { Tração } \\
\text { Perpendicular } \\
\left(\mathbf{N} / \mathbf{m m}^{2}\right)\end{array}$ & $\begin{array}{c}\text { Desvio } \\
\text { Padrão } \\
\left(\mathbf{N} / \mathbf{m m}^{2}\right)\end{array}$ & CV(\%) \\
\hline NA & 0,10 & (NS1-BD) & $\mathrm{C}$ & 0,26 & 0,04 & 15,80 \\
\hline 0,35 & 0,40 & (NS2-MD) & B & $\mathbf{0 , 5 7}$ & 0,26 & 46,18 \\
\hline NA & 0,90 & (NS3-AD) & $\mathbf{A}$ & 1,24 & 0,29 & 23,54 \\
\hline 0,35 & 0,40 & (NS4-MDP) & BC & 0,35 & 0,06 & 16,84 \\
\hline
\end{tabular}

Nota: *(NA) = Não se aplica

Fonte: Próprio autor. 
Todos os tratamentos atenderam ao requisito da norma nacional e internacional para a adesão interna com exceção do tratamento NS4-MDP para a norma internacional. O tratamento NS2-MD apresentou média superior ao tratamento NS4-MDP. Os tratamentos NS1-BD e NS4-MDP apresentaram semelhança significativa ( $>00,05)$, cabe salientar que os tratamentos representam a média para baixa densidade e média densidade comercial (MDP) respectivamente (Tabela7). Os resultados podem indicar que as fibras da casca de coco verde influenciaram no desempenho das amostras.

Entre os tratamentos NS4 - MDP e NS2-MD também não ocorreu diferença estatística significativa $(\mathrm{p}<0,05)$, porém o tratamento NS2-MD de subprodutos da agroindústria apresentou a propriedade $38,59 \%$ superior (Tabela 7).

Os resultados do ensaio de tração perpendicular apresentaram coeficientes de variação que indicaram amostras de média homogeneidade e heterogêneas (SILVA et al., 2008). Os valores dos coeficientes de variação podem ser explicados pela falta de distribuição homogenia da resina entre as partículas e fibras durante o processo de fabricação dos painéis aglomerados. A dispersão dos valores obtidos (Grafico 6) pode indicar que o processo de produção deve ser analisado com maior atenção para possíveis melhorias, observando que os ensaios visam apresentar propriedades mecânicas homogêneas de suas amostras (SARTORI, 2012).

O resultado médio do tratamento NS1-BD se igualou ao resultado obtido por (CRAVO, 2013), o autor produziu painel hibrido de $20 \mathrm{~mm}$ de espessura com densidade média de $0,5 \mathrm{~g} / \mathrm{cm}^{3}$ na proporção de massa em $50 \%$ de casca de amendoim e $50 \%$ de fibras de coco verde e obteve resultado médio de $0,26 \mathrm{MPa}$.

Fiorelli et al. (2015), produziram painéis de partículas aglomerados fabricados com resíduos de madeira e fibra de coco verde em substituição a madeira na proporção de $75 \%$ e $25 \%$ respectivamente e com densidade aproximada de $0,80 \mathrm{~g} / \mathrm{cm}^{3}$, os autores obtiveram resultados médios para adesão interna igual a 1,20 MPa.

Colli et al. (2009) produziram painéis com densidade aproximada de $360 \mathrm{~kg} / \mathrm{m}^{3}$, fabricados com 30\% de fibra de coco verde, Cocus nucifera $L$., e $70 \%$ de partículas de madeira Paricá, Schyzolobium amazonicum Huber ex. Ducke, obtiveram resultados de 0,18 MPa para resistência á tração perpendicular.

Brito et al. (2004) experimentaram painéis variando entre $0,58 \mathrm{~g} / \mathrm{cm}^{3}$ e $0,73 \mathrm{~g} / \mathrm{cm}^{3} \mathrm{de}$ densidade e tratamentos com fibra da casca de coco verde em substituição a madeira nas 
proporções 30\%, utilizando adesivo ureia-formaldeído nas porcentagens de $6 \%$ e $8 \%$ obtiveram resultados para ligação interna entre 0,35 $\mathrm{MPa}$ e 0,57 $\mathrm{MPa}$.

Gráfico 6 - Medianas e dispersões de resultados de todos os tratamentos experimentais para os ensaios de tração perpendicular das amostras dos painéis aglomerado de partículas e fibras e MDP comercial

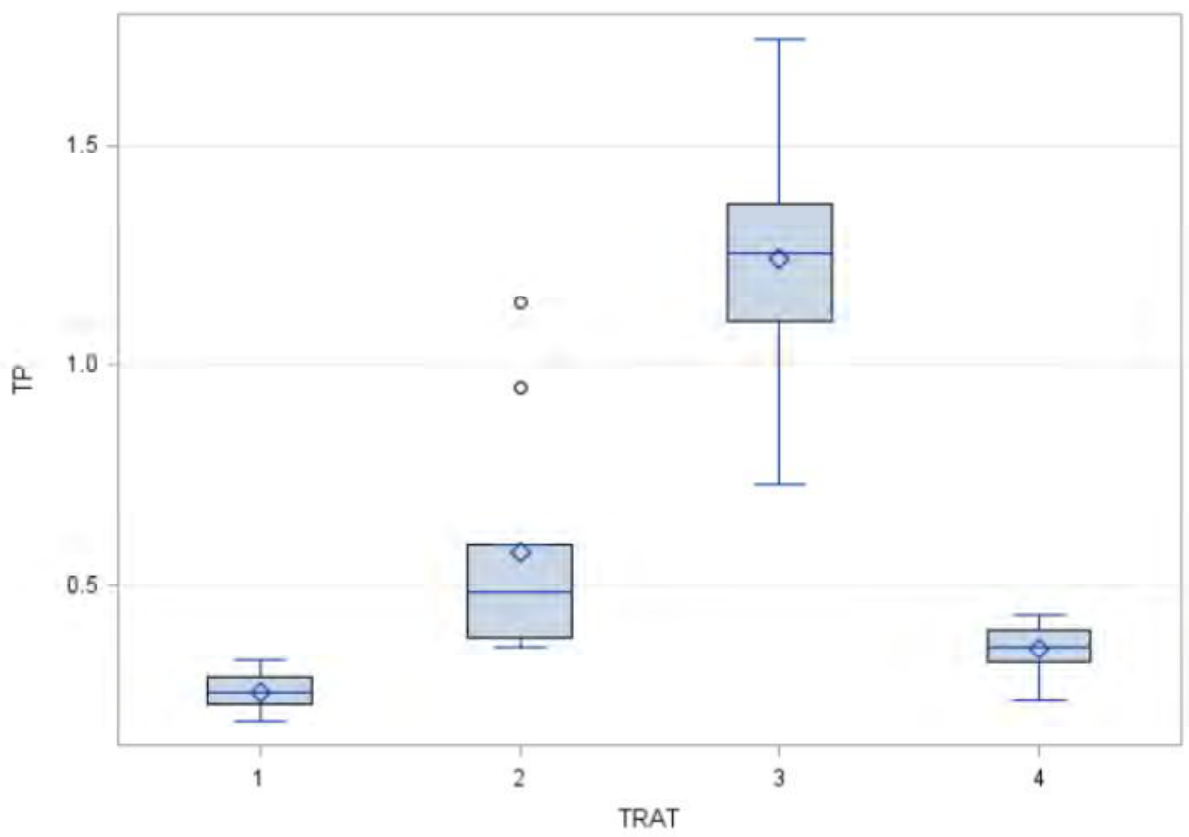

Fonte: Próprio autor.

\section{- Arranque de parafuso na superfície (APS)}

Nenhum dos tratamentos atenderam ao requisito da norma internacional ANSI A208.1 - 1999 Particleboard para os respectivos grupos de densidades (Tabela 8).

Tabela 8 - Resistência ao arranque de parafuso na superfície dos painéis de partículas e fibras e MDP comercial

\begin{tabular}{lccccc}
\hline $\begin{array}{c}\text { Requisito ANSI } \\
\text { A208.1 - 1999 }\end{array}$ & Tratamento & $\begin{array}{c}\text { Agrupamento } \\
\text { de Tukey }\end{array}$ & APS (N) & $\begin{array}{c}\text { Desvio Padrão } \\
\text { (N) }\end{array}$ & CV (\%) \\
\hline 400 & (NS1-BD) & C & $\mathbf{2 0 9 , 9 0}$ & 29,40 & 14,01 \\
900 & (NS2-MD) & B & $\mathbf{5 8 7 , 2 4}$ & 78,33 & 13,34 \\
1800 & (NS3-AD) & $\mathbf{A}$ & $\mathbf{1 . 4 2 7 , 4 4}$ & 263,72 & 18,47 \\
900 & (NS4-MDP) & B & $\mathbf{7 6 4 , 4 6}$ & 56,14 & 7,34 \\
\hline
\end{tabular}

Fonte: Próprio autor. 
Porém o tratamento NS2-MD e o tratamento NS4-MDP atenderam ao requisito da norma internacional ANSI A208.1 - 1999 na categoria baixa densidade até $640 \mathrm{~kg} / \mathrm{m}^{3}$. O tratamento NS3-AD atendeu ao requisito da norma internacional na categoria média densidade entre $640 \mathrm{~kg} / \mathrm{m}^{3}$ e $800 \mathrm{~kg} / \mathrm{m}^{3}$ (Tabela 8).

Colli et al. (2009) produziram painéis com densidade aproximada de $360 \mathrm{~kg} / \mathrm{m}^{3}$, fabricados com $30 \%$ de fibra de coco verde, Cocus nucifera $L$., e $70 \%$ de partículas de madeira Paricá, Schyzolobium amazonicum Huber ex. Ducke, obtiveram resultados de 294,98 $\mathrm{N}$ para arranque de parafuso.

Para a propriedade (APS) os tratamentos NS1-BD, NS2-MD e NS3-AD e NS1-BD com NS4-MDP apresentaram diferença estatística significativa $(p<0,05)$ e os tratamentos NS2-MD e NS4-MDP apresentaram resultados iguais estatisticamente. O tratamento NS3-AD apresentou o maior valor de dispersão entre as amostras (Tabela 8) e o tratamento NS4-MDP a maior uniformidade (Gráfico 7).

Gráfico 7 - Medianas e dispersões de resultados de todos os tratamentos experimentais para os ensaios de arranque de parafuso na superfície das amostras dos painéis aglomerado de partículas e fibras e MDP comercial

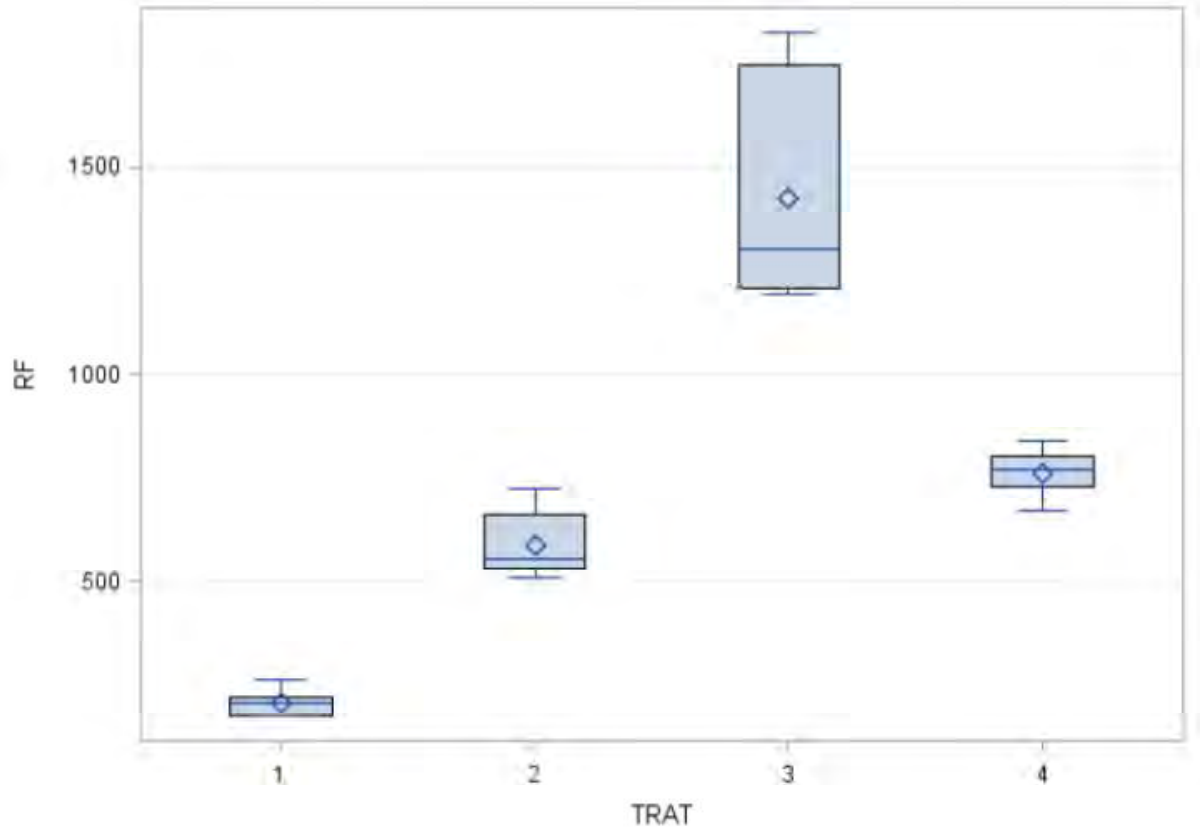

Fonte: Próprio autor. 


\section{- Arranque de parafuso no topo (APT)}

Nenhum dos tratamentos atenderam ao requisito da norma internacional ANSI A208.1 - 1999 Particleboard para os respectivos grupos de densidades (Tabela 9).

Porém o tratamento NS3-AD com densidade media de $777 \mathrm{~kg} / \mathrm{m}^{3}$ atendeu ao requisito da norma internacional ANSI A208.1 - 1999 na categoria média densidade entre $640 \mathrm{~kg} / \mathrm{m}^{3}$ e $800 \mathrm{~kg} / \mathrm{m}^{3}$ (Tabela 9). O tratamento NS2-MD apresentou valor superior ao tratamento NS4-MDP em 47,72\%, indicando que os subprodutos da agroindústria podem influenciar nesta propriedade.

Tabela 9 - Resistência ao arranque de parafuso no topo dos painéis de partículas e fibras e MDP comercial

\begin{tabular}{lccccc}
\hline $\begin{array}{c}\text { Requisito ANSI } \\
\text { A208.1 - 1999 }\end{array}$ & Tratamento & $\begin{array}{c}\text { Agrupamento } \\
\text { de Tukey }\end{array}$ & APT (N) & $\begin{array}{c}\text { Desvio } \\
\text { Padrão (N) }\end{array}$ & CV (\%) \\
\hline NA* & (NS1-BD) & D & $\mathbf{1 7 5 , 8 4}$ & 26,57 & 15,11 \\
\hline 800 & (NS2-MD) & $\mathbf{C}$ & $\mathbf{7 1 6 , 8 3}$ & 136,92 & 19,10 \\
\hline 1325 & (NS3-AD) & $\mathbf{A}$ & $\mathbf{8 7 5 , 8 8}$ & 184,14 & 21,03 \\
\hline 800 & (NS4-MDP) & $\mathbf{B}$ & $\mathbf{3 7 4 , 7 7}$ & 31,75 & 8,47 \\
\hline
\end{tabular}

Nota: *(NA): Não se aplica

Fonte: Próprio autor.

Bonilla Bueno (2015) em sua pesquisa testou painel de fibra de coco verde de baixa e média densidade, $518,43 \mathrm{~kg} / \mathrm{m}^{3}$ e $667,71 \mathrm{~kg} / \mathrm{m}^{3}$ respectivamente e obteve resultados para o arranque de parafuso no topo de $136 \mathrm{~N}$ e $449 \mathrm{~N}$ respectivamente. De acordo com o autor normalmente valores de arranque de parafuso no topo são menores que os da superfície por causa do gradiente de densidade do painel, exatamente onde o parafuso é fixado ocorre uma redução ou variação de densidade conforme dispersão de valores apresentados no Gráfico 8.

Para a propriedade (APT) os tratamentos NS1-BD, NS2-MD, NS3-AD e NS4-MDP apresentaram diferença estatística significativa $(\mathrm{p}<0,05)$. 
Gráfico 8 - Medianas e dispersões de resultados de todos os tratamentos experimentais para os ensaios de arranque de parafuso no topo das amostras dos painéis aglomerado de partículas e fibras e MDP comercial

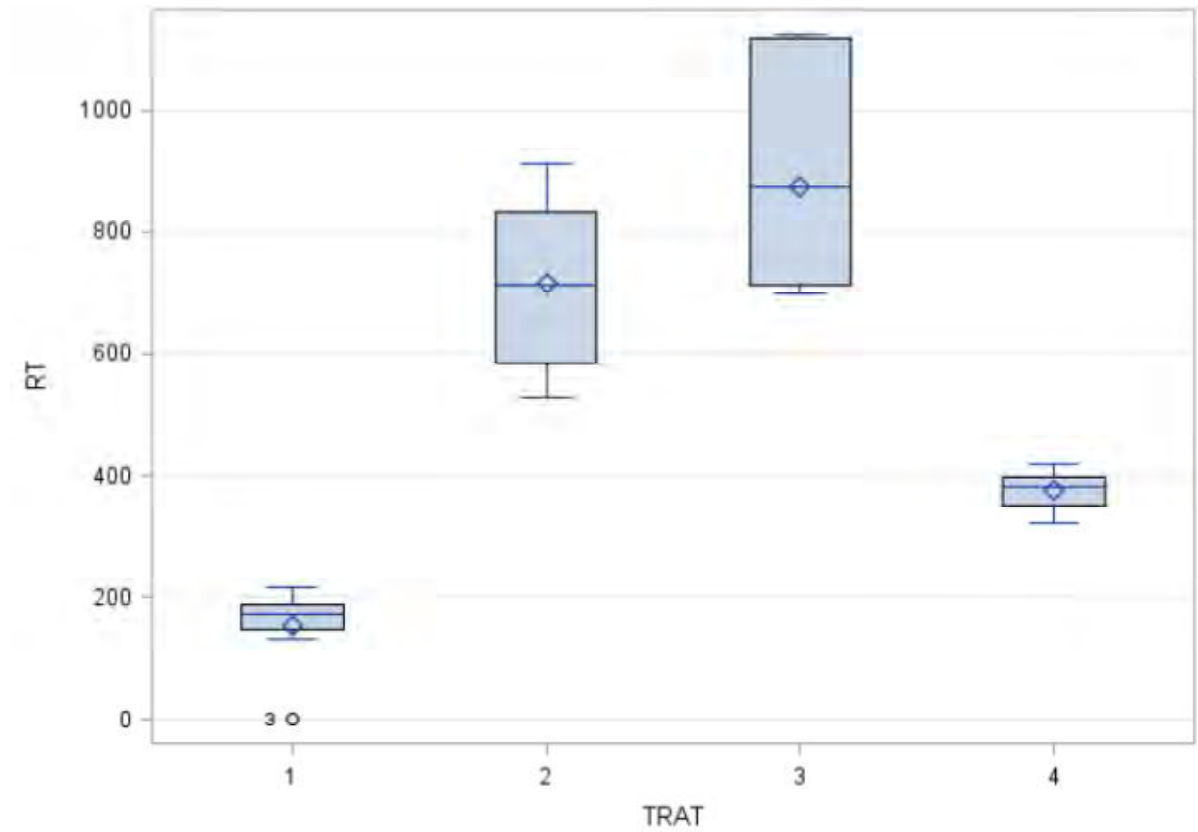

Fonte: Próprio autor.

\subsubsection{Considerações sobre as propriedades mecânicas}

Os resultados para MOR indicaram desempenho similar entre o painel aglomerado de média densidade de subprodutos da agroindústria e o painel comercial MDP, para MOE a similaridade de resultados ocorreu entre o painel aglomerado de alta densidade de subprodutos da agroindústria, fato que pode indicar que as fibras da casca de coco verde junto com o aumento da densidade podem ter melhorado as características das amostras em relação a esta propriedade.

Os resultados do ensaio de tração perpendicular apresentaram coeficientes de variação com porcentagens médias e altas, indicando amostras de média homogeneidade e heterogêneas (SILVA et al., 2008). Os tratamentos NS1-BD, NS2-MD e NS3-AD e os tratamentos NS3-AD e NS4-MDP apresentaram diferença estatística significativa $(p<0,05)$ (Tabela 7). Entre os tratamentos NS1-BD e NS4-MDP e entre os tratamentos NS2-MD e NS4-MDP não ocorreu diferença estatística, o que pode indicar que a substituição parcial das 
partículas de madeira por fibras da casca de coco verde pode ter influenciado na propriedade e que a variação de densidade não afetou o desempenho das amostras.

Em relação aos valores dos coeficientes de variação, as variações das porcentagens podem indicar falta de distribuição homogenia da resisa entre as partículas e fibras durante o processo de fabricação dos painéis aglomerados, porém vale ressaltar que os coeficientes de variação dos tratamentos NS1-BD e NS4-MDP ficaram próximos. Segundo (SARTORI, 2012) a dispersão dos resultados obtidos para esta propriedade pode indicar que o processo de produção deve ser analisado com maior atenção para possíveis melhorias, observando que se esperam valores de resultados homogêneos quando se testa propriedades mecânicas de qualquer natureza.

Bonilla Bueno (2015) em sua pesquisa referencia autores que expõem que resultados inferiores de arranque no topo em relação ao na superfície ocorre pelo fato do parafuso se localizar no ponto médio da espessura do painel de partículas, região onde ocorre o menor gradiente de densidade devido ao efeito de prensagem, fato que ocasiona densidade menor nesta faixa da espessura.

Diante dos resultados pode-se concluir que os tratamentos deste estudo apresentaram melhora nas propriedades mecânicas em função do aumento das densidades e demonstraram similaridade de desempenho entre o painel de média densidade de subprodutos da agroindústria e o painel comercial de média densidade MDP e podem indicar o potencial de aplicação dos subprodutos da agroindústria como matéria prima para a produção de painéis.

\subsubsection{Condutividade e resistência térmica dos painéis de partículas homogêneas}

A norma ABNT NBR 15220-2: 2003 Desempenho térmico de edificações apresenta propriedades térmicas de alguns materiais e a condutividade térmica média do aglomerado de partículas de madeira com densidade entre $550 \mathrm{~kg} / \mathrm{m}^{3}$ a $650 \mathrm{~kg} / \mathrm{m}^{3}$ e $650 \mathrm{~kg} / \mathrm{m}^{3}$ a $750 \mathrm{~kg} / \mathrm{m}^{3}$ é de $0,14 \mathrm{~W} / \mathrm{m} . \mathrm{K}$ e $0,17 \mathrm{~W} / \mathrm{m} . \mathrm{K}$ respectivamente.

A (Tabela 10) apresenta os valores médios da resistência e condutividade térmica de cada amostra dos tratamentos. 
Tabela 10 - Resistência e condutividade térmica dos painéis de partículas e fibras e MDP comercial

\begin{tabular}{|c|c|c|c|c|}
\hline \multicolumn{5}{|c|}{ Resistência térmica (Rt) } \\
\hline Tratamento & $\begin{array}{c}\text { Agrupamento } \\
\text { de Tukey }\end{array}$ & $\begin{array}{c}\text { Resistência } \\
\text { térmica }(\mathrm{Rt}) \\
\left(\mathbf{m}^{2} . \mathbf{K} / \mathbf{W}\right)\end{array}$ & $\begin{array}{l}\text { Desvio Padrão } \\
(\mathrm{Rt})\left(\mathrm{m}^{2} \cdot \mathrm{K} / \mathrm{W}\right)\end{array}$ & $\begin{array}{c}\text { Coeficiente de } \\
\text { variação }(\mathrm{Rt})(\%)\end{array}$ \\
\hline (NS1-BD) & $\mathbf{A}$ & 0,0962 & 0,0025 & 2,63 \\
\hline (NS2-MD) & $\mathbf{A}$ & 0,0925 & 0,0024 & 2,55 \\
\hline (NS3-AD) & $\mathbf{A}$ & 0,0912 & 0,0046 & 4,99 \\
\hline (NS4-MDP) & $\mathbf{A}$ & 0,0900 & 0,0050 & 5,58 \\
\hline \multicolumn{5}{|c|}{ Condutividade térmica $(\mathbf{C t})$} \\
\hline Tratamento & $\begin{array}{c}\text { Agrupamento } \\
\text { de Tukey }\end{array}$ & $\begin{array}{c}\text { Condutividade } \\
\text { térmica }(\mathrm{Ct}) \\
(\mathrm{W} / \mathrm{m} . \mathrm{K})\end{array}$ & $\begin{array}{l}\text { Desvio Padrão } \\
(\mathrm{Ct})(\mathrm{W} / \mathrm{m} . \mathrm{K})\end{array}$ & $\begin{array}{c}\text { Coeficiente de } \\
\text { variação }(\mathrm{Ct})(\%)\end{array}$ \\
\hline (NS1-BD) & B & 0,155 & 0,0043 & 2,78 \\
\hline (NS2-MD) & $\mathbf{A B}$ & 0,162 & 0,0072 & 4,49 \\
\hline (NS3-AD) & $\mathbf{A}$ & 0,167 & 0,0080 & 4,78 \\
\hline (NS4-MDP) & $\mathbf{A}$ & 0,172 & 0,0101 & 5,89 \\
\hline
\end{tabular}

Fonte: Próprio autor.

Para a condutividade os tratamentos NS2-MD, NS3-AD e NS4-MDP não apresentaram diferença estatística significativa $(p>0,05)$, os tratamentos NS1-BD e NS2-BD são estatisticamente iguais. O tratamento NS1-BD apresentou a menor condutividade térmica.

Com o propósito de comparar a condutividade dos painéis de partículas aglomeradas de subprodutos da agroindústria, na (Tabela 11) resumem-se resultados de outros painéis de partículas produzidos com diferentes materiais orgânicos, conforme exposto por (CRAVO, 2013). 
Tabela 11 - Condutividade térmica de painéis de partículas de fibras lignocelulósicas

\begin{tabular}{lccc}
\hline \multicolumn{1}{c}{ Painéis } & $\begin{array}{c}\text { Densidade } \\
\left(\mathbf{K g} / \mathbf{m}^{\mathbf{3}}\right)\end{array}$ & $\begin{array}{c}\text { Condutividade térmica } \\
(\mathbf{C t})(\mathbf{W} / \mathbf{m} . \mathbf{K})\end{array}$ & Fonte \\
\hline Painel de Kenaf & $100-250$ & 0,052 & $\begin{array}{c}\text { Xu et al. (2004) } \\
\text { Panyakaew e } \\
\text { Fotios (2011) } \\
\text { Painel de casca de coco }\end{array}$ \\
$\begin{array}{l}\text { Panyakaew e } \\
\text { Painel de bagaço de cana }\end{array}$ & $250-350$ & 0,057 & Fotios (2011 \\
Painel de caule de algodão & $150-450$ & 0,052 & Zhou et al. (2010) \\
$\begin{array}{l}\text { Painel hibrido (amendoin e } \\
\text { fibras da casca de coco verde) } \\
\text { (NS1-BD) }\end{array}$ & $\mathbf{5 0 0}$ & 0,085 & Cravo (2013) \\
\hline
\end{tabular}

Fonte: Própria autoria - Adaptado Cravo (2013).

\subsubsection{Considerações sobre as propriedades térmicas}

Cravo (2013) referencia em seu trabalho estudos que correlacionam o aumento da densidade ao aumento da condutividade térmica dos painéis de partículas, visto que os vazios entre as fibras dos painéis decrescem com o aumento da densidade. Outro fator que pode alterar a condutividade é a mistura de diferentes matérias primas na produção dos painéis, cada material possui uma condutividade térmica específica. $\mathrm{O}$ autor acrescenta que o tipo de resina e porcentagem aplicada também pode influenciar, quanto maior a porcentagem de resina maior pode ser a condutividade.

Todos os tratamentos apresentaram valores similares e que atendem ao requisito normativo que as classifica como material isolante de acordo com a norma ABNT NBR 15220-2: 2003 - Desempenho térmico de edificações.

\subsection{Apresentação das propriedades físicas, mecânicas e térmicas da placa de} fibrocimento

Seguindo as recomendações da norma RILEM - Testing Methods for Fibre Reinforced Cement-Based Composites determinou-se as propriedades das amostras da placa de fibrocimento. Os corpos de prova da placa de fibrocimento foram ensaiados e como não houve cruzamentos de tratamentos a análise estatística adotada foi a descritiva, os resultados 
se encontram resumidos nos quadros seguintes e comparados a alguns requisitos normativos e referências utilizadas por empresas fabricantes de componentes em fibrocimento.

\subsubsection{Propriedades físicas}

- Absorção de água e porosidade aparente

A (Tabela 12) apresenta os valores médios para absorção de água e porosidade aparente média da amostra da placa de fibrocimento.

Tabela 12 - Absorção de água e porosidade aparente das amostras da placa de fibrocimento

\begin{tabular}{ccccc}
$\begin{array}{c}\text { NBR 7581-2: 2012 } \\
\text { Requisito máximo } \\
\text { para absorção } \\
(\%)\end{array}$ & $\begin{array}{c}\text { Absorção de água } \\
\text { média (\%) }\end{array}$ & $\begin{array}{c}\text { Desvio } \\
\text { Padrão (\%) }\end{array}$ & $\begin{array}{c}\text { Porosidade aparente } \\
\text { média (\%) }\end{array}$ & $\begin{array}{c}\text { Desvio } \\
\text { Padrão (\%) }\end{array}$ \\
\hline $37 \%$ & $\mathbf{2 8 , 0 8}$ & 0,28 & $\mathbf{3 7 , 5 4}$ & 0,25 \\
\hline
\end{tabular}

Fonte: Próprio autor.

A amostra da placa de fibrocimento atendeu ao requisito da norma NBR 7581-1: 2012 para a propriedade absorção de água.

\section{- Densidade seca e saturada}

A (Tabela 13) apresenta os valores médios para densidade seca e saturada da amostra da placa de fibrocimento.

Tabela 13 - Densidade seca e saturada das amostras da placa de fibrocimento

\begin{tabular}{ccccc}
\hline $\begin{array}{c}\text { Requisito NBR } \\
\mathbf{1 5 4 9 8} \\
\left(\mathbf{k g} / \mathbf{m}^{3}\right)\end{array}$ & $\begin{array}{c}\text { Densidade saturada } \\
\text { média }\left(\mathbf{k g} / \mathbf{m}^{3}\right)\end{array}$ & $\begin{array}{c}\text { Desvio Padrão } \\
\left(\mathrm{kg} / \mathrm{m}^{3}\right)\end{array}$ & $\begin{array}{c}\text { Densidade seca } \\
\text { média }\left(\mathbf{k g} / \mathbf{m}^{3}\right)\end{array}$ & $\begin{array}{c}\text { Desvio Padrão } \\
\left(\mathrm{kg} / \mathrm{m}^{3}\right)\end{array}$ \\
\hline $1400-1800$ & $\mathbf{1 7 1 2}$ & 2,20 & $\mathbf{1 3 3 7}$ & 4,49 \\
\hline
\end{tabular}

Fonte: Próprio autor. 
A amostra da placa de fibrocimento atendeu ao intervalo do requisito da norma NBR 7581-1: 2012 para as propriedades densidade seca e saturada.

\subsubsection{Considerações sobre as propriedades físicas}

A amostra da placa de fibrocimento atendeu aos requisitos da norma NBR 15498: 2016 - Placas de fibrocimento sem amianto - Requisitos e métodos de ensaio.

\subsubsection{Propriedades mecânicas}

A Tabela 14 apresenta as propriedades mecânicas das amostras da placa de fibrocimento.

Tabela 14 - Propriedades mecânicas da placa de fibrocimento: MOR (módulo de resistência à flexão estática), LPO (Limite de proporcionalidade) e MOE (módulo de elasticidade)

\begin{tabular}{|c|c|c|c|c|c|c|}
\hline $\begin{array}{l}\text { *Requisito NBR } \\
\text { 15498: } 2016 \\
\text { (Mpa) }\end{array}$ & $\begin{array}{l}\text { MOR } \\
\text { (MPa) }\end{array}$ & $\begin{array}{l}\text { Desvio Padrão } \\
\text { (MPa) }\end{array}$ & $\begin{array}{c}\text { LPO } \\
(\mathrm{MPa})\end{array}$ & $\begin{array}{l}\text { Desvio Padrão } \\
\text { (MPa) }\end{array}$ & $\begin{array}{l}\text { MOE } \\
\text { (MPa) }\end{array}$ & $\begin{array}{c}\text { Desvio } \\
\text { Padrão (MPa) }\end{array}$ \\
\hline $4 \mathrm{Mpa}$ & 7,66 & 0,15 & 4,91 & 0,52 & 4969,83 & 696,43 \\
\hline
\end{tabular}

Nota: *Não se aplica para LPO e MOE

Fonte: Próprio autor.

A amostra deste experimento atende os requisitos da norma NBR 15498: 2016 Placas de fibrocimento sem amianto - Requisitos e métodos de ensaio. Os resultados atenderam aos requisitos para placas da classe A correspondente à condição saturada nas categorias 2 e 3 .

\subsubsection{Considerações sobre as propriedades mecânicas}

Os ensaios mecânicos produziram resultados que indicam a possibilidade da placa de fibrocimento ser aplicada em condições internas e externas se protegidas com revestimento de 
acordo com a norma NBR 15498: 2016 - Placas de fibrocimento sem amianto - Requisitos e métodos de ensaio.

\subsubsection{Condutividade e resistência térmica das amostras da placa de}

\section{fibrocimento}

Determinou-se a resistência e condutividade térmica média da amostra da placa de fibrocimento conforme norma ABNT NBR 15220-2: 2003 Desempenho térmico de edificações (Tabela 15):

Tabela 15 - Resistência e condutividade térmica da placa de fibrocimento

\begin{tabular}{|c|c|c|c|}
\hline \multicolumn{4}{|c|}{ Resistência térmica } \\
\hline $\begin{array}{l}\text { Requisito NBR 15220-2: } \\
2003\end{array}$ & $\begin{array}{c}\text { Resistência térmica } \\
(\mathbf{R t}=\mathbf{R}+\mathbf{R s e})\left(\mathbf{m}^{2} \cdot \mathbf{K} / \mathbf{W}\right)\end{array}$ & $\begin{array}{l}\text { Desvio Padrão } \\
(\mathrm{Rt})\left(\mathrm{m}^{2} \cdot \mathrm{K} / \mathrm{W}\right)\end{array}$ & $\begin{array}{c}\text { Coeficiente de } \\
\text { variação (Rt) (\%) }\end{array}$ \\
\hline$>0,14$ & 0,15 & 0,0008 & 0,53 \\
\hline \multicolumn{4}{|c|}{ Condutividade térmica } \\
\hline $\begin{array}{l}\text { Requisito NBR 15220-2: } \\
2003\end{array}$ & $\begin{array}{c}\text { Condutividade } \\
\text { térmica }(\mathrm{Ct})(\mathrm{W} / \mathrm{m} . \mathrm{K})\end{array}$ & $\begin{array}{c}\text { Desvio Padrão (Ct) } \\
\text { (W/m.K) }\end{array}$ & $\begin{array}{c}\text { Coeficiente de } \\
\text { variação }(\mathbf{C t}) \\
(\%)\end{array}$ \\
\hline$<0,65$ & $\mathbf{0 , 3 5}$ & 0,016 & 4,56 \\
\hline
\end{tabular}

Fonte: Próprio autor.

A amostra da placa de fibrocimento apresentou resultado similar ao requisito da norma NBR 15220-2: 2003 para a propriedade resistência térmica e atendeu ao requisito para a propriedade condutividade térmica.

\subsubsection{Considerações sobre as propriedades térmicas}

A condutividade térmica e a resistência térmica da amostra da placa de fibrocimento atenderam aos requisitos da norma ABNT NBR 15220: 2005 - Desempenho térmico de edificações. Entretanto a placa (sem se associar a outros materiais ou sem compor um sistema de vedação) não atende ao requisito da norma ABNT NBR 15575-4: 2013 Edificações habitacionais - Desempenho Parte 4: Sistemas de vedações verticais internas e externas SVVIE, onde apresenta na tabela 13 que o valor para a propriedade transmitância térmica (U) deve ser menor ou igual a $3,7 \mathrm{~W} / \mathrm{m}^{2} . \mathrm{K}$. De acordo com a norma a transmitância térmica é o 
inverso da resistência total do material (ASSOCIAÇÃO BRASILEIRA DE NORMAS TÉCNICAS, 2013).

\subsection{Apresentação das propriedades físicas, mecânicas e térmicas dos painéis} sanduíches

Os resultados seguintes resumem as propriedades físicas, mecânicas e térmicas dos painéis sanduíches com núcleo de painéis aglomerados de subprodutos da agroindústria (partículas de fibras da casca de coco verde e de madeira pinus) e MDP comercial. As propriedades foram analisadas em um único grupo cruzando todos os tratamentos e a análise inferencial resultou em valores médios avaliando se ocorreu ou não diferença estatística significativa $(\mathrm{p}<0,05)$. Os resultados obtidos pelo teste Tukey apresentam os grupos das médias de cada tratamento. Para todas as tabelas do agrupamento de Tukey, as médias seguidas das mesmas letras não apresentaram diferença estatística significativa ( $p>0,05)$.

\subsubsection{Propriedades físicas dos painéis sanduíche}

\section{- - Densidade aparente das amostras dos painéis sanduíche}

A densidade aparente média de cada tratamento dos painéis sanduíche se encontra na (Tabela 16), os resultados estão descritos com as densidades de seus componentes, a placa de fibrocimento (faces) e os painéis de partículas aglomerado de subprodutos da agroindústria e MDP comercial (núcleos).

Tabela 16 - Densidade média dos painéis sanduíche, das faces e núcleos

\begin{tabular}{|c|c|c|c|c|c|}
\hline Tratamento & $\begin{array}{c}\text { Densidade aparente } \\
\text { média dos painéis } \\
\text { sanduíches } \\
\left(\mathrm{kg} / \mathrm{m}^{3}\right)\end{array}$ & $\begin{array}{c}\text { Desvio } \\
\text { Padrão } \\
\left(\mathrm{kg} / \mathrm{m}^{3}\right)\end{array}$ & CV $(\%)$ & $\begin{array}{c}\text { Densidade } \\
\text { aparente média } \\
\text { das faces } \\
\left(\mathrm{kg} / \mathrm{m}^{3}\right)\end{array}$ & $\begin{array}{c}\text { Densidade } \\
\text { aparente média } \\
\text { dos núcleos } \\
\left(\mathrm{kg} / \mathrm{m}^{3}\right)\end{array}$ \\
\hline (PS1 - BD) & 713 & 12,40 & 1,74 & 1332 & 359 \\
\hline (PS2 - MD) & 814 & 17,88 & 2,20 & 1332 & 571 \\
\hline$(\mathbf{P S 3}-\mathbf{A D})$ & 912 & 20,70 & 2,27 & 1332 & 777 \\
\hline (PS4 - MDP) & 850 & 11,64 & 1,37 & 1332 & 640 \\
\hline
\end{tabular}

Fonte: Próprio autor. 
Para efeito de comparação apresentamos referências normativas e produtos aplicados nos setores da construção civil.

A ABNT NBR 15220: 2003 - Desempenho térmico de edificações apresenta a densidade de diversos materiais aplicados em sistemas de vedação (Tabela B.3), os valores de densidades são relacionados às condutividades desses componentes construtivos e alguns exemplos são: (i) tijolos entre 1000 e $2000 \mathrm{~kg} / \mathrm{m}^{3}$; (ii) gesso cartonado entre $750 \mathrm{~kg} / \mathrm{m}^{3}$ e 1000 $\mathrm{kg} / \mathrm{m}^{3}$; (iii) argamassas entre 1800 e $2100 \mathrm{~kg} / \mathrm{m}^{3}$ e (iv) aglomerado de partículas de madeira entre $650 \mathrm{~kg} / \mathrm{m}^{3}$ e $750 \mathrm{~kg} / \mathrm{m}^{3}$.

A empresa Gypsum S.A Mineração, Indústria e Comércio, produz painel sanduíche de $40 \mathrm{~mm}$ de espessura, com peso médio descrito em $31,2 \mathrm{~kg} / \mathrm{m}^{2}$ e com resultado médio de densidade em $780 \mathrm{~kg} / \mathrm{m}^{3}$.

A empresa Eternit produz painéis de $40 \mathrm{~mm}$ e $55 \mathrm{~mm}$ com densidades entre 800 $\mathrm{kg} / \mathrm{m}^{3}$ e $682 \mathrm{~kg} / \mathrm{m}^{3}$ respectivamente, apesar do aumento da espessura do painel ocorre redução da densidade (DIVISÃO WALL, 2017).

A Empresa Brasilit do Grupo Saint-Gobain apresenta painéis de 14, 23 e $40 \mathrm{~mm}$ de espessura com densidades entre $820 \mathrm{Kg} / \mathrm{m}^{3} ; 980 \mathrm{Kg} / \mathrm{m}^{3}$ e $1250 \mathrm{Kg} / \mathrm{m}^{3}$ respectivamente (GUIA DE SISTEMAS PARA PRODUTOS PLANOS, 2011).

\subsubsection{Considerações sobre as propriedades físicas}

O compósito formado por painéis aglomerados de partículas de subprodutos da agroindústria, por painel MDP comercial e pela placa de fibrocimento proporcionou um material com densidades similares aos produzidos nos setores da indústria da construção civil, conforme exemplos apresentados no item 4.4.1. Vale ressaltar que a espessura média dos painéis sanduíches de todos os tratamentos se aproximou das medidas comerciais oferecidas no mercado da construção civil com $43 \mathrm{~mm}$ de espessura.

Assim componentes e elementos de vedação de densidades inferiores aos sistemas convencionais e que proporcionam similaridades de aplicação e desempenho, podem auxiliar no tempo de execução, custo de transporte, alívio de cargas sobre estruturas de fundação entre outros benefícios.

Observa-se que os resultados sinalizaram a viabilidade técnica de se produzir um compósito de densidades compatíveis aos painéis sanduíche comercialmente fabricados e 
podem incentivar pesquisas sobre a utilização dos subprodutos da agroindústria como matéria prima para a produção de componentes não convencionais construtivos e indicar uma disposição final mais produtiva.

\subsubsection{Propriedades mecânicas dos painéis sanduíche - ensaio de flexão}

Os resultados médios dos ensaios de flexão estática das amostras de cada tratamento dos painéis sanduíche compostos por núcleo de painéis de partículas aglomerado de subprodutos da agroindústria e painel MDP comercial para módulo de ruptura (MOR) e módulo de elasticidade (MOE) seguiram as diretrizes da norma ASTM C393/393M-11 Standard Test Method for Core Shear Properties of Sandwich Construction by Beam Flexure e se encontram resumidos na (Tabela 17).

\section{- MOR (módulo de ruptura) e MOE (módulo de elasticidade)}

O modo de ruptura dos tratamentos foi similar, ocorreu uma pequena diferença de rigidez entre os corpos de prova confirmada pelos baixos valores de dispersão. Os tratamentos PS2 - MD com PS4 - MDP e PS2 - MD com PS3 - AD não apresentaram diferença estatística significativa $(p<0,05)$ para o ensaio mecânico $(M O R)$ e os tratamentos PS2 - MD; PS3 - AD e PS4 - MDP para o (MOE) (Tabela 17).

Empresas que atuam no mercado ${ }^{1}$ da construção civil e produzem painéis sanduíche com faces de placas de fibrocimento e núcleo de madeira maciça ou laminada, com exceção da LP Brasil que utiliza o painel OSB, apresentam resultados de ensaios para carga máxima distribuída de $500 \mathrm{~kg} / \mathrm{m}^{2}$, os painéis variam entre $23 \mathrm{~mm}$ e $55 \mathrm{~mm}$ de espessura e são aplicados como divisórias, lajes secas e mezaninos.

A empresa Brasilit apresenta para seu painel sanduíche $9 \mathrm{MPa}$ de resistência média à ruptura na flexão estática com densidades variando entre $820 \mathrm{~kg} / \mathrm{cm}^{3}$ e $1250 \mathrm{~kg} / \mathrm{cm}^{3}$.

Para a instalação de pisos elevados a norma ABNT NBR 11802: 1991 - Pisos elevados - Especificação atribui à placa de madeira aglomerada de alta densidade encapsulada em aço com espessura de $40 \mathrm{~mm}$ o requisito de 4,40 MPa para carga admissível (ASSOCIAÇÃO BRASILEIRA DE NORMAS TÉCNICAS).

\footnotetext{
${ }^{1}$ Decorlit, Gypsum, Brasilit e LP Brasil.
} 
Tabela 17 - Resultados de (MOR) e (MOE) de cada tratamento dos painéis sanduíche

Módulo de ruptura (MOR)

\begin{tabular}{|c|c|c|c|c|c|}
\hline Tratamento & $\begin{array}{c}\text { Agrupamento } \\
\text { estatístico de } \\
\text { Tukey }\end{array}$ & $\begin{array}{c}\text { Força } \\
\text { Normal (N) }\end{array}$ & MOR (MPa) & $\begin{array}{c}\text { Desvio } \\
\text { Padrão } \\
\text { MOR (MPa) }\end{array}$ & $\begin{array}{c}\text { Coeficiente de } \\
\text { variação MOR } \\
(\%)\end{array}$ \\
\hline (PS1 - BD) & $\mathbf{C}$ & 4168 & 7,40 & 0,52 & 6,98 \\
\hline (PS2 - MD) & $\mathbf{A B}$ & 7377 & 12,05 & 1,87 & 15,48 \\
\hline (PS3 - AD) & $\mathbf{A}$ & 10815 & 15,76 & 2,16 & 13,72 \\
\hline (PS4 - MDP) & B & 6497 & 10,01 & 1,04 & 10,39 \\
\hline \multicolumn{6}{|c|}{ Módulo de elasticidade (MOE) } \\
\hline Tratamento & $\begin{array}{c}\text { Agrupamento } \\
\text { estatístico de } \\
\text { Tukey }\end{array}$ & $\begin{array}{c}\text { Força } \\
\text { Normal (N) }\end{array}$ & MOE (MPa) & $\begin{array}{c}\text { Desvio } \\
\text { Padrão } \\
\text { MOE (MPa) }\end{array}$ & $\begin{array}{c}\text { Coeficiente de } \\
\text { variação MOE } \\
(\%)\end{array}$ \\
\hline (PS1 - BD) & B & 2830 & 601 & 3,23 & 8,86 \\
\hline (PS2 - MD) & $\mathbf{A}$ & 3540 & 1059 & 129,40 & 12,22 \\
\hline (PS3 - AD) & $\mathbf{A}$ & 4329 & 1105 & 82,97 & 7,51 \\
\hline (PS4 - MDP) & $\mathbf{A}$ & 3559 & 911 & 36,96 & 4,05 \\
\hline
\end{tabular}

Fonte: Próprio autor.

Os resultados dos ensaios para os painéis sanduíche de todos os tratamentos, com exceção do tratamento PS1 - BD, superam a tensão média de ruptura na flexão estática dos exemplos citados anteriormente (Tabela 17).

Os painéis sanduíche de subprodutos da agroindústria de média e alta densidade apresentaram um comportamento similar ao painel sanduiche de MDP comercial. A (Figura 56) ilustra a curva da relação tensão-deformação e a similaridade de comportamento dos corpos de prova. 
Figura 56 - Curvas dos ensaios de flexão (MOR) e (MOE) para os painéis sanduíche formados por núcleos de painéis aglomerados de subprodutos da agroindústria e painel MDP comercial com faces de placa de fibrocimento

(a)

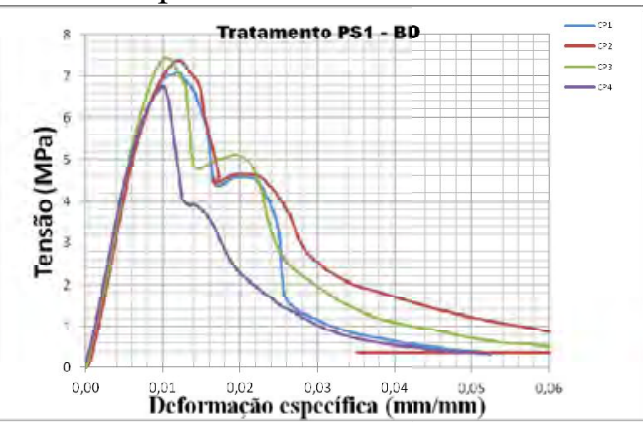

(c)

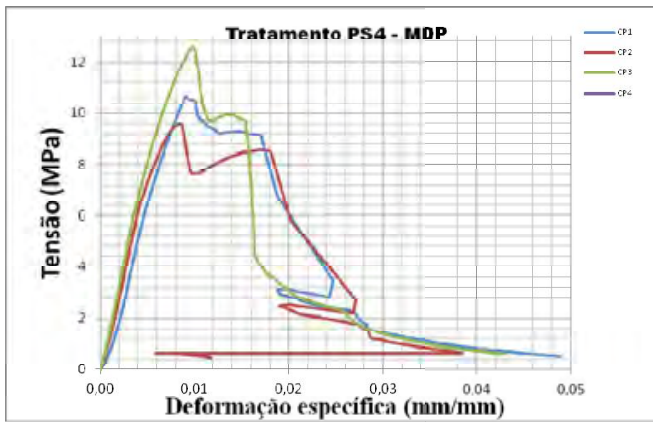

(b)

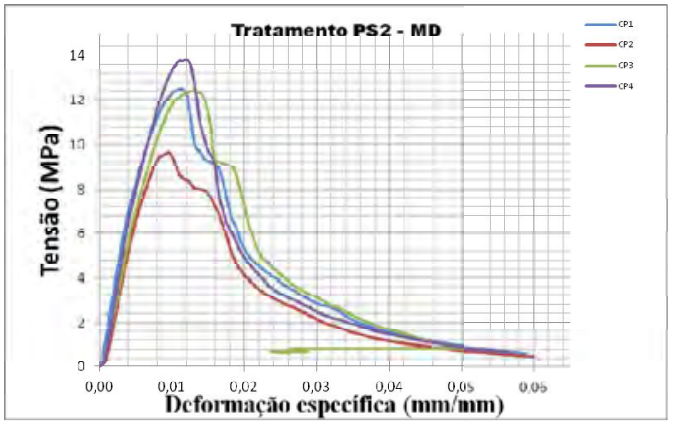

(d)

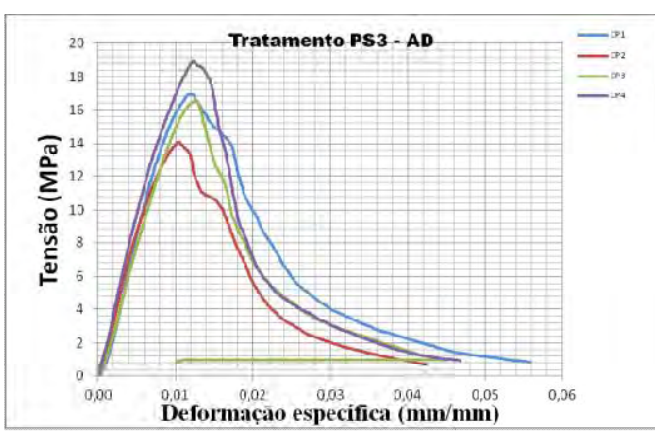

(a) Tratamento PS1-BD (b) Tratamento PS2-MD (c) Tratamento PS4-MDP (d) Tratamento PS3-AD

Fonte: Própria autoria.

- Fs ultimate - Core shear ultimate strength at maximum force to failure (Resistência máxima ao cisalhamento de núcleo); $\sigma$ - Facing stress (Tensão máxima na face do painel sanduíche) e Fs yield - Core shear yield strength at $2 \%$ force offset shear strain (Resistência ao cisalhamento de núcleo em $2 \%$ de deformação)

As próximas tabelas apresentam os resultados médios dos ensaios de flexão estática das amostras dos painéis sanduíches compostos por núcleo de painéis aglomerado de partículas de subprodutos da agroindústria e painel MDP comercial de cada tratamento seguindo as diretrizes da norma ASTM C393/393M-11 Standard Test Method for Core Shear Properties of Sandwich Construction by Beam Flexure.

Linul e Marsavina (2015), em seu experimento produziram um mapa de modo de falhas para painéis sanduiche com núcleo de espuma de poliuretano, conforme descrição dos 
autores foi possível observar nas curvas de tensão-deformação as zonas de falhas durante os ensaios.

O corpo de prova CP3 do tratamento PS1 - BD foi utilizado como uma curva típica para descrever os seguimentos como segue: (i) a zona linear elástica está representada entre os pontos A-B; (ii) a partir do ponto B o material começa a sofrer a deformação plástica que ocorre entre B-C, ponto inicial do escoamento onde o material pode sofrer a deformação irreversível (escoamento da face e núcleo); (iii) o ponto $\mathrm{C}$ representa a tensão máxima de ruptura, onde pode ocorrer a ruptura de núcleo e face simultaneamente; (iv) seguido do cisalhamento do núcleo entre C-D; (v) entre D-E ocorre um pequeno aumento de carga e (vi) novamente o cisalhamento do núcleo entre E-F ocorrendo a ruína do painel (Figura 57).

Figura 57 - Curva representativa dos seguimentos que descrevem o mapa de modo de falhas

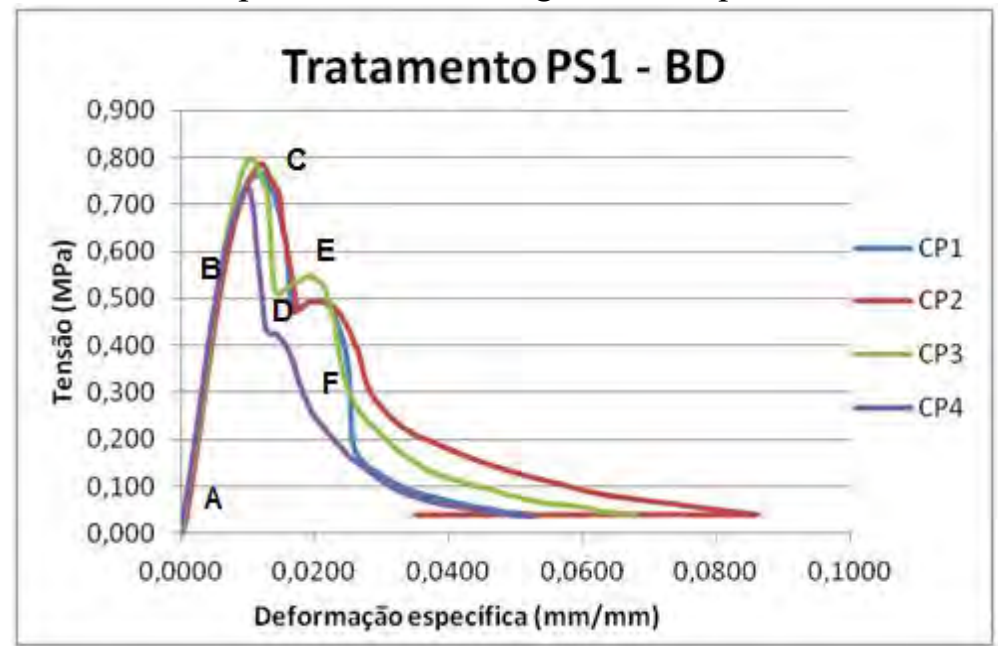

Fonte: Própria autoria.

\section{Fs ultimate}

O ensaio avalia a resistência máxima ao cisalhamento de núcleo dos painéis sanduíche e os resultados de todos os tratamentos são apresentados e analisados a seguir.

Os tratamentos PS2 - MD e PS4 - MDP não apresentaram diferença estatística significativa $(\mathrm{p}<0,05)$. Apesar do aumento das tensões, o comportamento das curvas dos tratamentos dos painéis com núcleos de subprodutos da agroindústria foi similar (Figura 58), vale destacar que este ensaio analisa o núcleo do painel sanduiche (cisalhamento de núcleo) e os resultados mostram que o aumento da densidade de núcleo proporcionou melhora na 
propriedade mecânica testada em comparação ao painel sanduíche de núcleo de MDP comercial, conforme (Tabela 18).

Tabela 18 - Resultado médio da Tensão máxima de cisalhamento de núcleo de cada tratamento dos painéis sanduíche

\begin{tabular}{lcccc}
\hline Tratamento & $\begin{array}{c}\text { Agrupamento } \\
\text { estatístico de } \\
\text { Tukey }\end{array}$ & $\begin{array}{c}\text { Fs ultimate } \\
\text { (MPa) }\end{array}$ & $\begin{array}{c}\text { Desvio Padrão } \\
\text { (MPa) }\end{array}$ & $\begin{array}{c}\text { Coeficiente de } \\
\text { variação (\%) }\end{array}$ \\
\hline (PS1 - BD) & $\mathbf{C}$ & $\mathbf{0 , 7 7 5}$ & 0,026 & 3,14 \\
(PS2 - MD) & $\mathbf{B}$ & $\mathbf{1 , 3 6 8}$ & 0,188 & 13,74 \\
(PS3 - AD) & $\mathbf{A}$ & $\mathbf{2 , 0 0 3}$ & 0,250 & 12,50 \\
(PS4 - MDP) & $\mathbf{B}$ & $\mathbf{1 , 2 0 5}$ & 0,119 & 9,88 \\
\hline
\end{tabular}

Fonte: Próprio autor.

Figura 58 - Curvas do ensaio de tensão máxima de ruptura de cisalhamento de núcleo do painel sanduíche de todos os tratamentos experimentais

(a)
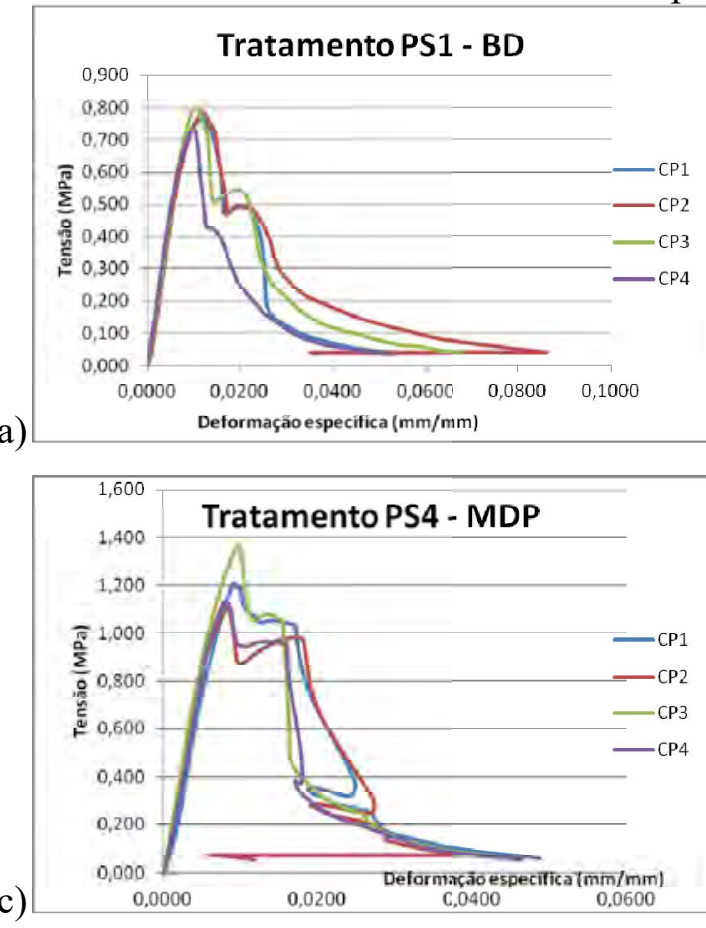

(b)
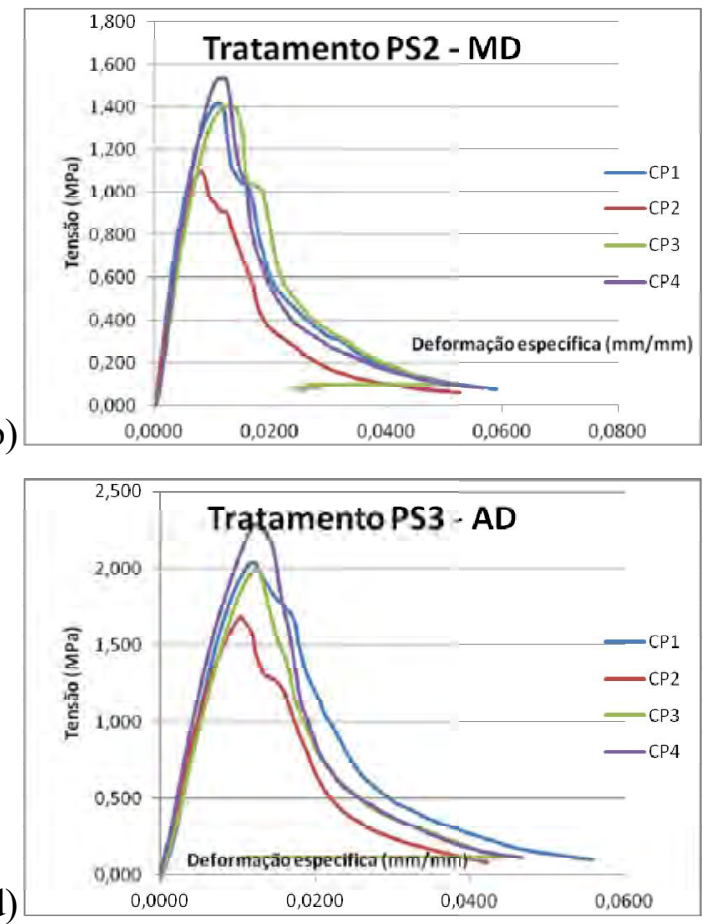

(a) Tratamento PS1-BD (b) Tratamento PS2-MD

(c) Tratamento PS4-MDP (d) Tratamento PS3-AD

Fonte: Própria autoria. 


\section{Facing stress $(\sigma)$}

O ensaio avalia a tensão máxima de tração e compressão nas faces do painel sanduíche e se apresentam na (Tabela 19).

Tabela 19 - Resultado médio da tensão máxima nas faces de cada tratamento dos painéis sanduíche

\begin{tabular}{lcccc}
\hline Tratamento & $\begin{array}{c}\text { Agrupamento } \\
\text { estatístico de } \\
\text { Tukey }\end{array}$ & $\sigma\left(\mathbf{N} / \mathbf{m m}^{2}\right)$ & $\begin{array}{c}\text { Desvio Padrão } \\
\left(\mathbf{N} / \mathbf{m m}^{2}\right)\end{array}$ & $\begin{array}{c}\text { Coeficiente de } \\
\text { variação (\%) }\end{array}$ \\
\hline (PS1 - BD) & $\mathbf{C}$ & $\mathbf{9 , 6 5}$ & 0,347 & 3,59 \\
(PS2 - MD) & $\mathbf{B}$ & $\mathbf{1 7 , 0 8}$ & 2,365 & 13,85 \\
(PS3 - AD) & $\mathbf{A}$ & $\mathbf{2 5 , 0 4}$ & 3,142 & 12,55 \\
(PS4 - MDP) & $\mathbf{B}$ & $\mathbf{1 5 , 0 4}$ & 1,47 & 9,77 \\
\hline
\end{tabular}

Fonte: Próprio autor.

Os tratamentos PS2 - MD e PS4 - MDP não apresentaram diferença estatística significativa $(\mathrm{p}<0,05)$ (Tabela19). As curvas do ensaio estão representadas na (Figura 59) no qual se visualiza a similaridade do comportamento das tensões nas faces do painel.

Apesar dos painéis sanduiches com núcleos de média densidade produzidos com painéis aglomerados de fibras da casca de coco verde e partículas de madeira de subprodutos da agroindústria e com o painel comercial MDP não apresentarem o mesmo acabamento na superfície por causa da matéria prima empregada na produção, a resina aderiu igualmente bem nas interfaces dos painéis (núcleos) e das faces (placas de fibrocimento) (Figura 50 e Figura 51).

O ensaio avalia as tensões nas faces, mas conforme revisão bibliográfica o núcleo tem a função de transmitir as tensões de cisalhamento para as faces, com a associação do núcleo com a face e com um núcleo mais denso, os resultados indicam que as reações às faces são amenizadas pelo comportamento mecânico do núcleo, segundo PETRAS (1998) o núcleo separa e carrega cargas entre as faces e o adesivo transmite o cisalhamento, e (BERTINI, 1995) confirma as afirmações e acrescenta que os núcleos podem ter resistência a flexão, mas esta função é das faces. 
Figura 59 - Curvas do ensaio de tensão máxima na face dos painéis sanduíche para todos os tratamentos experimentais

(a)
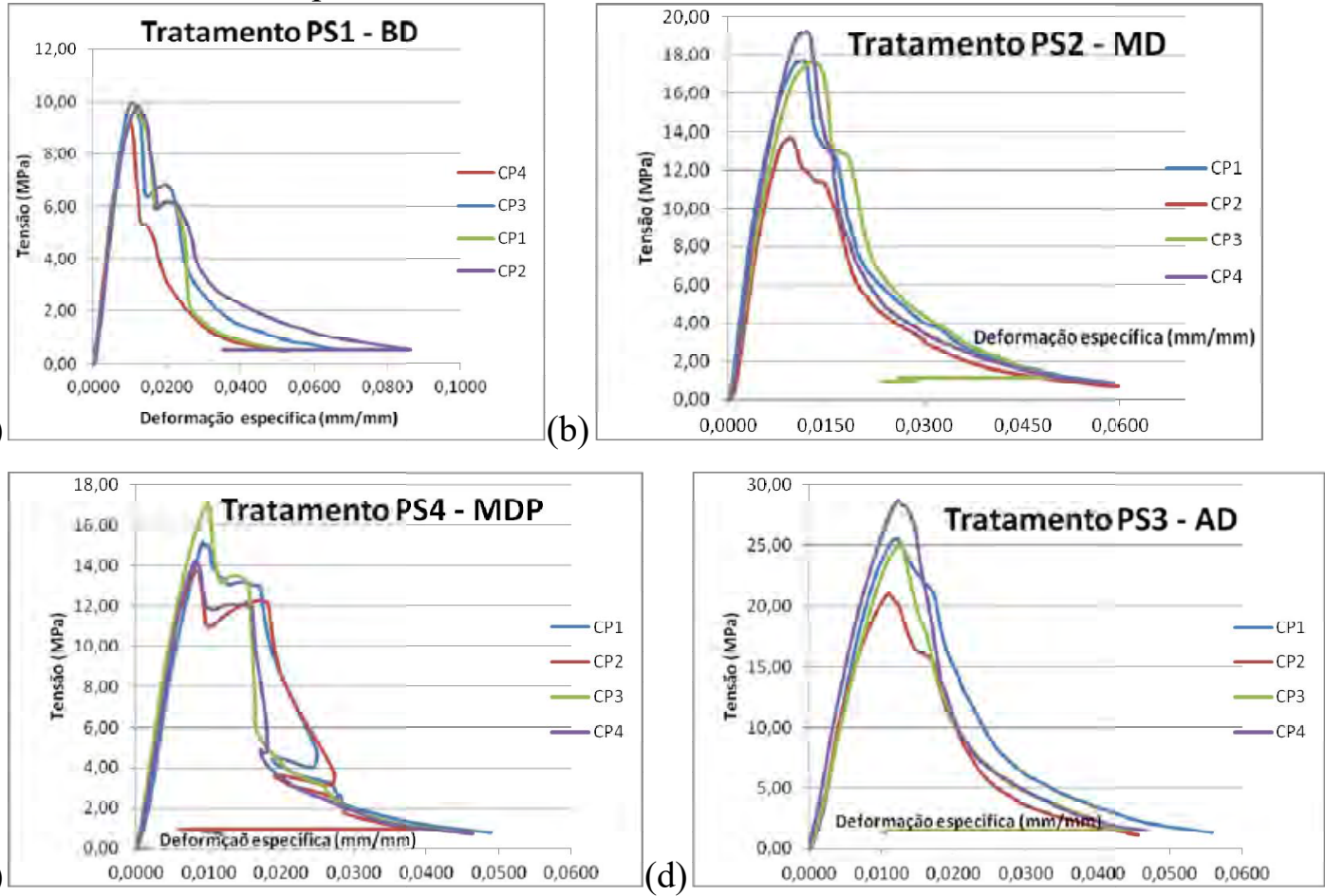

(a) Tratamento PS1-BD (b) Tratamento PS2-MD (c) Tratamento PS4-MDP (d) Tratamento PS3-AD

Fonte: Própria autoria.

Os resultados indicam que o núcleo do painel sanduíche composto por painéis de subprodutos da agroindústria de média densidade transmitiu tensões e contribuiu com a face de forma similar ao núcleo do painel sanduiche composta de MDP comercial produzindo tensões de faces similares.

\section{Fs yield}

O ensaio avalia a resistência ao cisalhamento de núcleo de materiais que atingem escoamento (deformação) acima de $2 \%$ e os resultados estão resumidos na (Tabela 20).

Os tratamentos PS1 - BD com PS4 - MDP e PS4 - MDP com PS2 - MD não apresentaram diferença estatística significativa $(\mathrm{p}<0,05)$ (Tabela 20). O comportamento elástico das curvas dos tratamentos se apresentou similar independente da relação tensão versus deformação específica. Os tratamentos PS1 - BD e PS3 - AD apresentaram entre os tratamentos as curvas mais similares apesar da dispersão dos resultados (Figura 60). 
Tabela 20 - Resultado médio da tensão de cisalhamento de núcleo de cada tratamento dos painéis sanduíche em $2 \%$ de deformação

\begin{tabular}{|c|c|c|c|c|}
\hline Tratamento & $\begin{array}{c}\text { Agrupamento } \\
\text { estatístico de } \\
\text { Tukey }\end{array}$ & $\begin{array}{l}\text { Fs yield } \\
\left(\mathrm{N} / \mathbf{m m}^{2}\right)\end{array}$ & $\begin{array}{c}\text { Desvio } \\
\text { Padrão } \\
\left(\mathrm{N} / \mathbf{m m}^{2}\right)\end{array}$ & $\begin{array}{l}\text { Coeficiente de } \\
\text { variação (\%) }\end{array}$ \\
\hline (PS1 - BD) & $\mathrm{C}$ & 0,583 & 0,164 & 28,22 \\
\hline (PS2 - MD) & B & 0,838 & 0,184 & 21,92 \\
\hline (PS3 - AD) & $\mathbf{A}$ & 1,700 & 0,335 & 19,68 \\
\hline (PS4 - MDP) & BC & 0,648 & 0,010 & 1,48 \\
\hline
\end{tabular}

Fonte: Próprio autor.

Figura 60 - Curvas do ensaio de tensão de cisalhamento de núcleo dos painéis sanduíche em $2 \%$ de deformação de todos os tratamentos experimentais

(a)

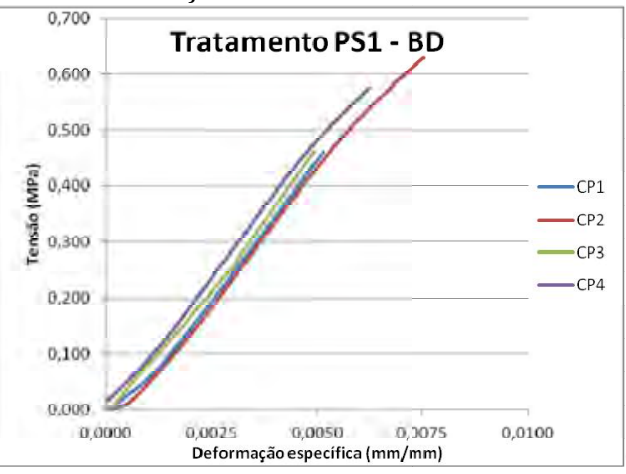

(c)

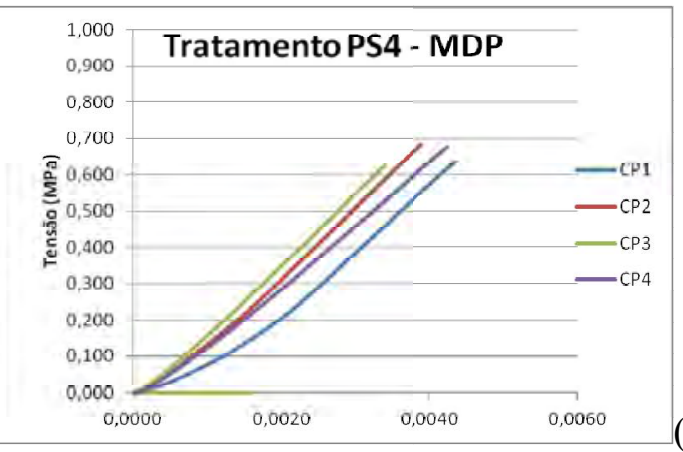

(b)
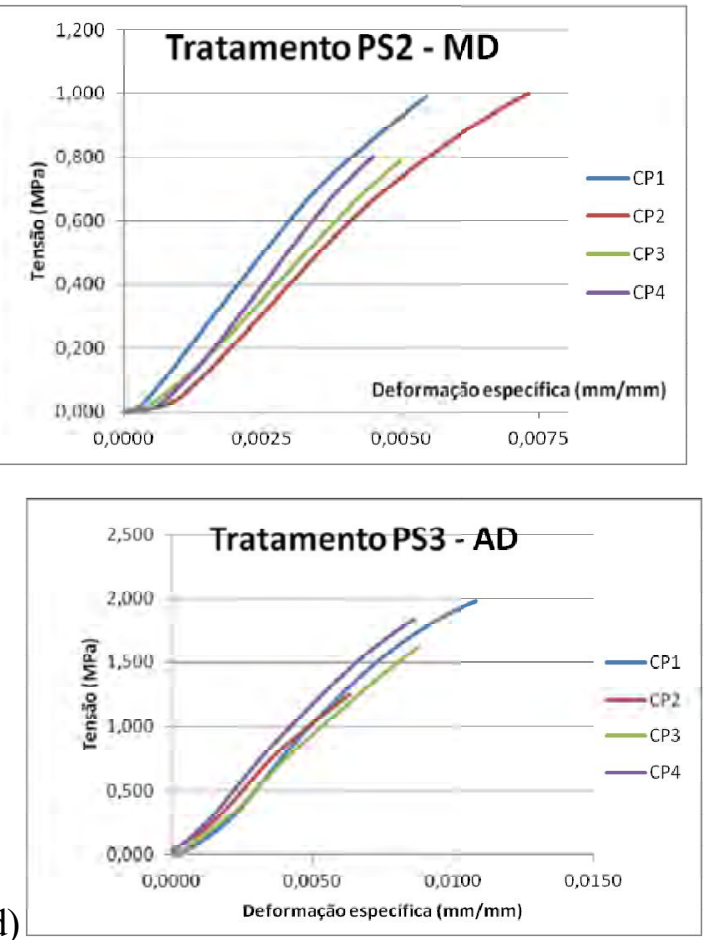

(a) Tratamento PS1-BD (b) Tratamento PS2-MD (c) Tratamento PS4-MDP (d) Tratamento PS3-AD

Fonte: Própria autoria. 
Os limites de proporcionalidade das amostras do tratamento PS4 - MDP se apresentaram similares, de acordo com a baixa dispersão de valores (Tabela 20) indicando homogeneidade do material. O núcleo do painel sanduíche composto por painéis aglomerados de subprodutos da agroindústria de média densidade apresentou um comportamento similar ao núcleo do painel sanduiche de MDP comercial.

\subsubsection{Considerações sobre os ensaios de flexão}

De modo geral o comportamento das curvas dos tratamentos dos painéis sanduíche com núcleo de painéis aglomerado de subprodutos da agroindústria foram similares e os resultados demonstraram que o aumento da densidade de núcleo proporcionou melhora nas propriedades mecânicas testadas em comparação ao painel sanduiche com núcleo de MDP comercial. Os resultados indicaram a contribuição do núcleo em função do aumento da densidade.

É possível notar uma redução repentina nas tensões atuantes após o primeiro sinal de ruptura, o comportamento dos corpos de prova durante o ensaio pode estar relacionado com o rompimento simultâneo do núcleo e da face inferior dos painéis sanduíches, posteriormente no estágio elasto-plástico não ocorreu variações bruscas na curva até a ruína dos painéis. $\mathrm{O}$ comportamento mecânico indicou que os núcleos trabalham como reforço recebendo e transmitindo tensões para as faces, reações esperadas conforme revisão bibliográfica do assunto.

A resina demonstrou capacidade de manter os painéis sanduíche de todos os tratamentos em funcionamento similar sob os esforços solicitantes, manteve os núcleos dos sanduíches compostos por painéis aglomerados de partículas de subprodutos da agroindústria e de MDP comercial aderidos às faces.

Observa-se que os resultados do ensaio de flexão estática demonstraram que os painéis sanduíche atenderam aos requisitos de forma similar a produtos oferecidos comercialmente, para serem aplicados como pisos ou vedação vertical, dessa forma o desempenho do compósito se apresentou satisfatório e com potencialidade técnica de aplicação em sistemas construtivos na construção civil. 


\subsubsection{Falhas mecânicas dos painéis sanduíche}

O comportamento da resina foi satisfatório, os corpos de prova não apresentaram delaminação de faces com núcleo em nenhum dos tratamentos. Não foi observada ruptura por corte de núcleo próximo aos apoios. Todos os tratamentos apresentaram semelhança no modo de ruptura (Figura 61).

Figura 61 - Amostras de todos os tratamentos experimentais dos painéis sanduíche após ensaios mecânicos de flexão estática para análise das falhas mecânicas

(a)
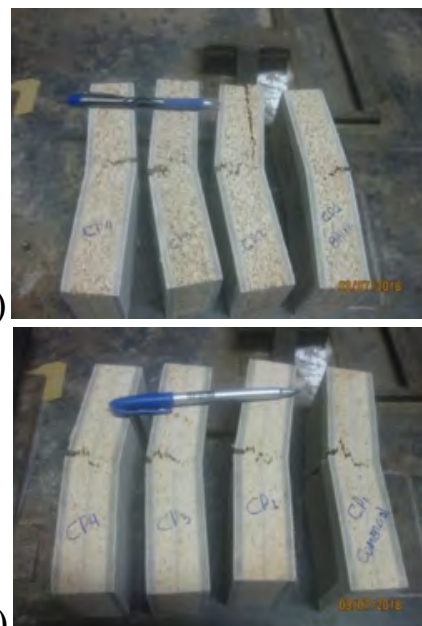

(d)

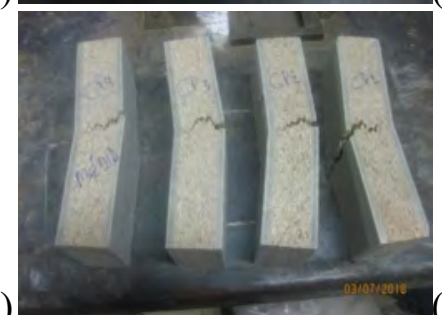

$(\mathrm{g})$

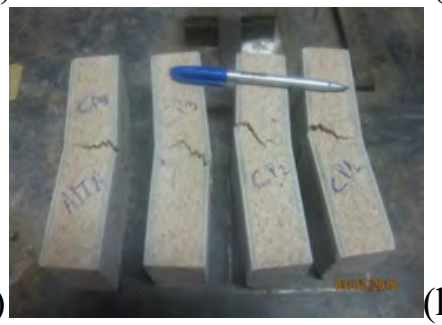

(b)

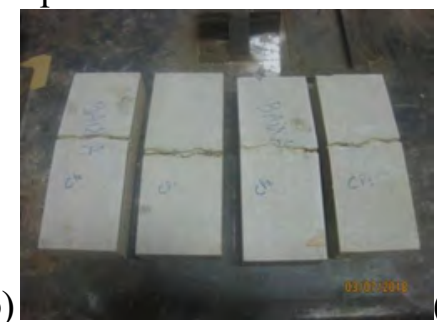

(c)
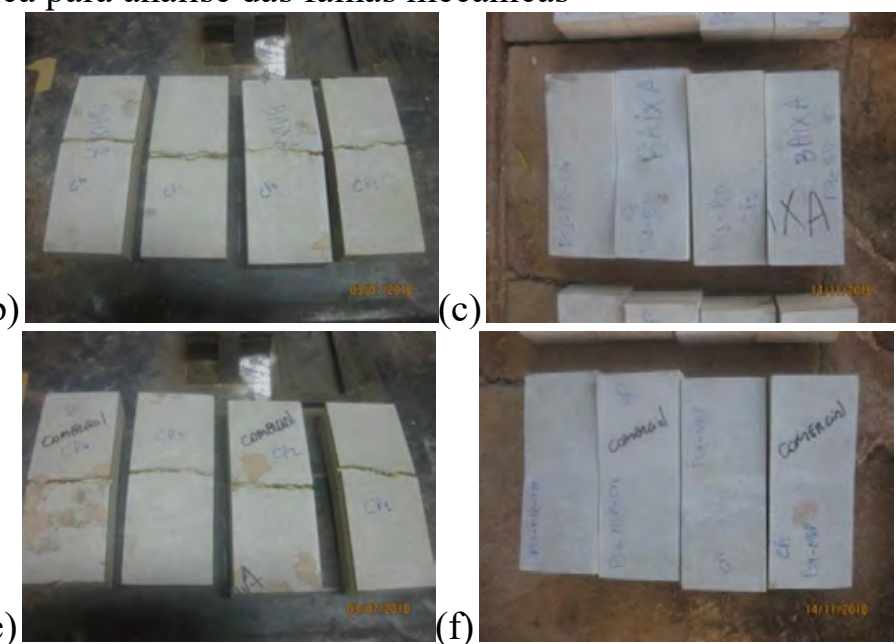

e)

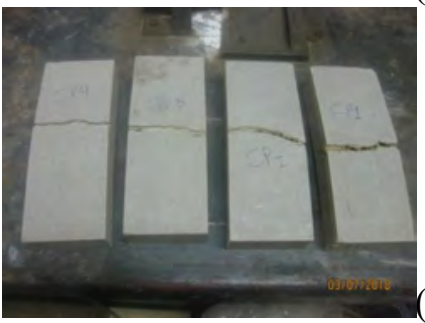

(h)

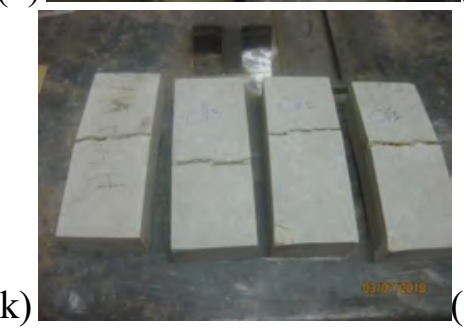

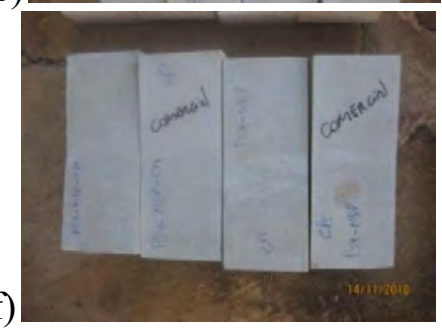

(f)
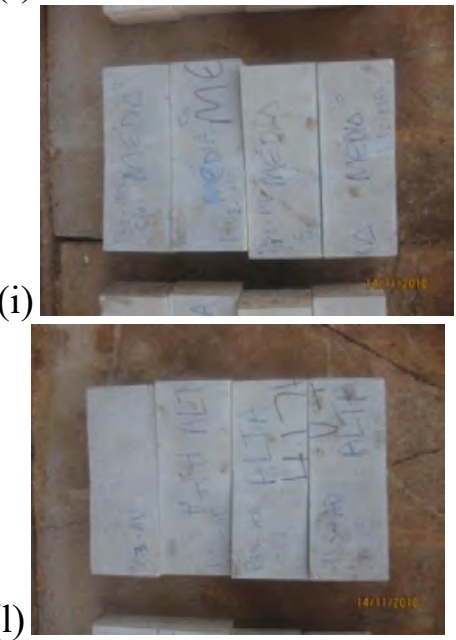

(a) vista lateral; (b) vista face inferior e (c) vista face superior (Tratamento PS1-BD). (d) vista lateral; (e) vista face inferior e (f) vista face superior (Tratamento PS2-MDP). (g) vista lateral; (h) vista face inferior e (i) vista face superior (Tratamento PS2-MD). (j) vista lateral; (k) vista face inferior e (l) vista face superior (Tratamento PS3-AD).

Fonte: Própria autoria. 
Nos ensaios, nota-se que a ruptura de núcleo ocorreu por corte e apenas um corpo de prova sofreu cisalhamento paralelo à face, corpo de prova $\mathrm{CP} 2$ de baixa densidade do tratamento (PS1 - BD). As faces não apresentaram indentação local nos pontos de aplicação de carga.

Se os materiais que compõem o painel sanduíche apresentarem módulo de cisalhamento ou de compressão e tração insuficientes pode ocorrer no núcleo ou face falha prematura, localizadas ou ambas. Na proximidade ao local de aplicação de carga, podem ocorrer problemas relacionados ao estresse por compressão na face. Ocasionalmente falhas de faces podem causar rupturas ou esmagamento de núcleo (ASTM 393/393M-11 STANDARD TEST METHOD FOR CORE SHEAR PROPERTIES OF SANDWICH CONSTRUCTIONS BY BEAM FLEXURE). Quando ocorre falha de face e núcleo simultaneamente nos arredores do ponto de aplicação de carga, pode surgir dificuldade para a determinação da sequência da falha. Ao analisar o corpo de prova após a ruptura, a avaliação pode ser comprometida visto que os materiais podem apresentar falhas em locais similares (ASTM 393/393M-11 STANDARD TEST METHOD FOR CORE SHEAR PROPERTIES OF SANDWICH CONSTRUCTIONS BY BEAM FLEXURE).

\subsubsection{Considerações sobre as falhas mecânicas}

Não houve indícios de descolamento de faces, esmagamento na região de apoio ou de aplicação de carga. Apenas um corpo de prova (CP2) do tratamento PS1-BD apresentou cisalhamento do núcleo paralelo à face juntamente com o cisalhamento de corte (Figura 62a). A falha pode estar relacionada à falta de homogeneidade de mistura das partículas e fibras com a resina durante a produção dos painéis aglomerados de partículas de subprodutos da agroindústria para o núcleo do painel sanduíche. Durante a amostragem, por escolha aleatória, esse corpo de prova pode ter vindo da região da borda do painel, onde ocorrem áreas de menor de densidade. 


\subsubsection{Condutividade e resistência térmica dos painéis sanduíche}

Seguindo as diretrizes da norma ABNT NBR 15220: 2003 - Desempenho térmico de edificações, determinou-se a resistência térmica e condutividade média de cada amostra do painel sanduíche conforme (Tabela 21) a seguir:

Tabela 21 - Resistência e condutividade térmica de cada tratamento dos painéis sanduíche

Resistência térmica (Rt)

\begin{tabular}{|c|c|c|c|}
\hline Tratamento & $\begin{array}{c}\text { Resistência térmica (Rt) } \\
\left(\mathrm{m}^{2} \cdot \mathrm{K} / \mathrm{W}\right)\end{array}$ & $\begin{array}{c}\text { Desvio Padrão (Rt) } \\
\left(\mathrm{m}^{2} . \mathrm{K} / \mathrm{W}\right)\end{array}$ & $\begin{array}{c}\text { Coeficiente de variação } \\
\text { (Rt) (\%) }\end{array}$ \\
\hline (PS1 - BD) & 0,396 & 0,0036 & 0,920 \\
\hline (PS2 - MD) & 0,392 & 0,0084 & 2,150 \\
\hline$(\mathbf{P S 3}-\mathrm{AD})$ & 0,388 & 0,0102 & 2,620 \\
\hline (PS4 - MDP) & 0,385 & 0,0103 & 2,689 \\
\hline
\end{tabular}

Condutividade térmica $(\mathbf{C t})$

\begin{tabular}{cccc}
\hline Tratamento & $\begin{array}{c}\text { Condutividade térmica }(\mathbf{C t}) \\
(\mathbf{W} / \mathbf{m} . \mathbf{K})\end{array}$ & $\begin{array}{c}\text { Desvio Padrão }(\mathbf{C t}) \\
(\mathbf{W} / \mathbf{m} . \mathbf{K})\end{array}$ & $\begin{array}{c}\text { Coeficiente de variação } \\
(\mathbf{C t}) \mathbf{( \% )}\end{array}$ \\
\hline (PS1 - BD) & $\mathbf{0 , 1 0 4}$ & 0,0013 & 1,21 \\
$\mathbf{( P S 2}-\mathbf{M D})$ & $\mathbf{0 , 1 0 8}$ & 0,0007 & 0,63 \\
$(\mathbf{P S 3}-\mathbf{A D})$ & $\mathbf{0 , 1 0 6}$ & 0,0013 & 1,21 \\
$\mathbf{( P S 4}-\mathbf{M D P})$ & $\mathbf{0 , 1 1 1}$ & 0,0010 & 0,86 \\
\hline
\end{tabular}

Fonte: Próprio autor.

Os painéis sanduíches de núcleo composto por subprodutos da agroindústria apresentaram resultados similares ao painel sanduíche de núcleo composto por MDP comercial (Tabela 21). Segundo os parâmetros e diretrizes da norma NBR 15220: 2003 e requisitos mínimos estabelecidos pela Norma NBR 15575-4: 2013 Edificações habitacionais Desempenho Parte 4: Sistemas de vedações verticais internas e externas - SVVIE os painéis são classificados como isolantes. A transmitância térmica média do painel sanduíche de 
subprodutos da agroindústria e do painel sanduíche de MDP comercial é igual a aproximadamente $2,55\left(\mathrm{~W} / \mathrm{m}^{2} . \mathrm{K}\right)$ e $2,59\left(\mathrm{~W} / \mathrm{m}^{2} . \mathrm{K}\right)$ respectivamente.

De acordo com a tabela D.3 da norma NBR 15220-3: 2003 paredes formadas por tijolos maciços assentados na menor dimensão, revestidos por argamassa e espessura aproximada de 0,15 metros, podem apresentar transmitância térmica média do conjunto em torno de $3,13\left(\mathrm{~W} / \mathrm{m}^{2} . \mathrm{K}\right)$ e resistividade térmica igual a $0,319\left(\mathrm{~m}^{2} . \mathrm{K} / \mathrm{W}\right)$.

Um estudo proposto por Santos et al. (2015), que avaliou comparativamente o comportamento térmico de alvenarias estruturais formadas por blocos cerâmicos e de concreto, seguindo os parâmetros e diretrizes da norma NBR 15220: 2003 e requisitos mínimos estabelecidos pela Norma NBR 15575-4: 2013, encontraram valores para transmitância térmica aproximada de $2,88\left(\mathrm{~W} / \mathrm{m}^{2} . \mathrm{K}\right)$ e conforme norma citada anteriormente que define a transmitância térmica como o inverso da resistência térmica total, resulta em uma resistividade térmica média aproximada igual a $0,347\left(\mathrm{~m}^{2} . \mathrm{K} / \mathrm{W}\right)$.

\subsubsection{Considerações sobre as propriedades térmicas}

A associação de diferentes materiais influencia nos resultados da condutividade e resistência térmica dos painéis sanduíche e estão relacionados com a massa específica do material e com as dimensões da espessura das composições. Assim se as amostras testadas possuem a mesmas dimensões pode-se fazer a comparação entre densidades das composições (VERAS, 2013).

No que diz respeito a este estudo, entre os tratamentos propostos, o painel sanduíche que atingiu maior resistividade térmica foi o do tratamento PS1 - BD, onde o valor médio resultou em $0,396 \mathrm{~m}^{2} . \mathrm{K} / \mathrm{W}$ e com transmitância térmica média aproximada de $2,52 \mathrm{~W} / \mathrm{m}^{2} . \mathrm{K}$. As propriedades apresentaram valores inferiores ao estabelecido para as zonas 3 a 8 segundo a norma ABNT NBR 15575-4: 2013 - Edificações habitacionais - Desempenho Parte 4: Sistemas de vedações verticais internas e externas - SVVIE. Assim pela similaridade de resultados e de acordo com a norma e revisão bibliográfica do assunto, os painéis sanduíche de núcleo de painéis aglomerado de partículas com subprodutos da agroindústria e com MDP comercial apresentaram comportamento térmico satisfatório comparado a um sistema de vedação composta por blocos ou tijolos cerâmicos de acordo com norma citada. 
Cabe salientar que os resultados da placa de fibrocimento isoladamente não atenderam ao requisito da norma citada anteriormente, para a propriedade transmitância térmica (U) o material analisado deve apresentar valor menor ou igual a $3,7 \mathrm{~W} / \mathrm{m}^{2} . \mathrm{K}$, assim pode-se considerar que a associação da placa de fibrocimento (faces) aos painéis aglomerados de partículas e fibras de subprodutos da agroindústria (núcleos) proporcionaram ao painel sanduíche características isolantes, a associação de materiais é uma das características que fazem dos painéis sanduíche um compósito aplicado em diversas áreas da engenharia, agrega em um único material propriedades físicas, mecânicas e térmicas. 


\section{CONCLUSÕES}

Com relação ao objetivo geral, foi possível produzir e avaliar o painel sanduíche composto por núcleo de painéis de partículas de fibra da casca de coco verde (Cocos nucifera) e maravalha de madeira pinus (Pinus sp) e MDP comercial conformado com faces de placa de fibrocimento. Os resultados indicaram que os painéis sanduíche avaliados nessa pesquisa apresentaram viabilidade técnica para serem utilizados como componente ou elemento de sistemas construtivos dos setores da construção civil. A utilização de subprodutos da agroindústria para a composição do núcleo do painel sanduiche potencializa o caráter inovador do compósito.

Com relação aos objetivos específicos pode-se afirmar que:

- $\quad$ Propriedades físicas, mecânicas e térmicas dos painéis de partículas aglomeradas (núcleo)

A análise das propriedades físicas e mecânicas dos painéis aglomerados demonstrou que as fibras da casca de coco verde e as partículas de madeira possuem potencialidade de aplicação como matéria prima de produção e, de forma geral, os painéis dessa pesquisa indicaram melhora nas propriedades em função do aumento das densidades. Considerando os requisitos da norma ANSI A208.1 - 1999 uma possível aplicação para estes painéis seria o núcleo de portas revestidas (designação LD-1) e o uso comercial geral interno não estrutural em condições secas (designação M-S e M-1).

Com relação às propriedades térmicas, todos os tratamentos apresentaram valores similares e atenderam ao requisito que os classifica como material isolante de acordo com a norma ABNT NBR 15220-2: 2003 - Desempenho térmico de edificações.

O trabalho evidenciou a potencialidade da utilização dos painéis de partículas aglomerados de partículas de fibras da casca de coco verde e de partículas de madeira Pinus como componente para a produção do núcleo dos painéis sanduíche e dessa maneira demonstrou uma disposição final mais produtiva para os subprodutos da agroindústria.

\section{- $\quad$ Propriedades físicas, mecânicas e térmicas da placa de fibrocimento (face)}

Os resultados dos ensaios físicos e mecânicos indicam a possibilidade da placa de fibrocimento ser aplicada em condições internas e externas se protegidas com revestimento 
(impregnação ou revestimento impermeável) e assim compor as faces do painel sanduíche de acordo com a norma ABNT NBR 15498: 2016 - Placas de fibrocimento sem amianto Requisitos e métodos de ensaio.

Com relação às propriedades térmicas, a placa fibrocimento não atendeu a todos os requisitos da norma ABNT NBR 15220-2: 2003 - Desempenho térmico de edificações.

\section{- $\quad$ Propriedades físicas dos painéis sanduíches}

Conforme ASTM C 271 - 1999 Standard Test Method for Density of Core Materials, os resultados indicaram que o compósito produzido com núcleo composto por painéis aglomerado de partículas de madeira pinus e fibras da casca de coco verde conformado com faces de placas de fibrocimento apresentaram densidades similares aos produtos comerciais existentes e aplicados nos setores da construção civil.

Assim o estudo demonstrou a viabilidade técnica de uma possível aplicação dos painéis aglomerados de subprodutos da agroindústria como um componente para a produção de painéis sanduíche.

\section{- $\quad$ Propriedades mecânicas dos painéis sanduiches}

Os painéis sanduíche foram planejados para o estudo da viabilidade técnica de aplicação como componentes ou elementos de sistemas construtivos industrializados, sua espessura se fundamentou em produtos comercialmente produzidos e diante dos resultados dos ensaios da face e do núcleo os painéis conforme diretrizes da norma ASTM C393/393M11 Standard Test Method for Core Shear Properties of Sandwich Construction by Beam Flexure, se apresentaram com potencialidade de aplicação. Comparados com os painéis sanduíche produzidos comercialmente, algumas possíveis aplicações seriam como divisórias, lajes secas, pisos elevados e mezaninos em áreas internas.

Com relação às falhas mecânicas a resina apresentou um comportamento satisfatório, não permitiu a delaminação de faces com o núcleo. As faces atenderam às solicitações de cargas pontuais evitando indentação local. Os núcleos apresentaram cisalhamento de corte após a ruptura de face confirmando a contribuição na transferência de cargas. 


\section{- $\quad$ Propriedades térmicas dos painéis sanduíches}

De acordo com os parâmetros e diretrizes da norma ABNT NBR 15220: 2003 e requisitos mínimos estabelecidos pela norma ABNT NBR 15575-4: 2013 os painéis sanduíches avaliados nesta pesquisa se enquadram na categoria de componente ou elemento construtivo isolante.

\section{TRABALHOS FUTUROS}

De acordo com Nogueira (2018), os estudos de desempenho de subsistemas construtivos têm produzido trabalhos relacionados ao comportamento térmico e acústico e a segurança do usuário, em atendimento aos requisitos básicos de habitabilidade. $\mathrm{O}$ autor acrescenta ainda o foco na minimização de impactos nas fases de uso e ocupação, como o consumo de energia para aquecimento e resfriamento de ambientes, o desconforto causado por ruído e outros fatores de transtorno aos usuários. A pesquisadora destaca ainda que a sustentabilidade têm produzido diversas pesquisas associadas em especial a busca por novos sistemas de vedação vertical. Nesse contexto a avaliação do desempenho de novos materiais em atendimento aos requisitos normativos estabelecidos pela ABNT NBR 15575: 2013: Desempenho de edificações habitacionais, se insere no objeto destas pesquisas e estudos futuros.

As edificações devem ser concebidas do ponto de vista técnico, econômico e social ao longo do seu ciclo de vida útil. Enquanto investimento, conhecer a durabilidade e saber a quantidade de tempo antes da necessidade de uma primeira manutenção e a frequência em que será repetida, auxilia na produção da metodologia adequada de conservação. Assim quanto maior for o ciclo, menor a periodicidade e o custo de manutenção. A perda gradual de desempenho é progressiva ao longo do tempo e o estado de degradação depende da análise dessa perda de desempenho, portanto são essenciais os estudos de modelos de previsão de vida útil das construções em detrimento ao custo-benefício de investidores e usuários (PEREIRA, 2018).

Outra questão em relação a avaliação dos sistemas construtivos é a análise do desempenho ambiental de edifícios, e uma das maneiras de se avaliar é o uso do ACV (Avaliação do Ciclo de Vida), que predominantemente reconhece os atributos dos produtos como custo, durabilidade, renovabilidade, teor reciclado, entre outros (BUENO, 2014). 
Diante das diversas possibilidades, estudos futuros que avaliem o desempenho, a durabilidade e os impactos ambientais potenciais gerados na produção de sistemas de vedação verticais tradicionais comparados aos produzidos com painéis sanduíche compostos por materiais não convencionais, podem auxiliar na divulgação de pesquisas relacionadas à utilização de fibras lignocelulósicas em componentes de sistemas construtivos e trazer avanços nas pesquisas sobre a industrialização da construção. 


\section{REFERÊNCIAS}

ABDOLPOUR, H.; ESCUSA, G.; SENA-CRUZ, J. M.; VALENTE, I. B.; BARROS, J. A. Axial performance of jointed wall panels. Journal of Composites for Construction, 2017, 21(4): 04017009.

AGÊNCIA BRASILEIRA DE DESENVOLVIMENTO INDUSTRIAL - ABDI - Manual da construção industrializada: Conceitos e Etapas. Volume 1, 208p: Estrutura e Vedação. Brasília, Distrito Federal, 2015.

ALMEIDA, M. I. A. Comportamento estrutural de painéis sanduíche compósitos para aplicações na indústria da construção. 2009. 185 p. Dissertação (Mestrado) - Universidade Técnica de Lisboa, Lisboa, Portugal, 2009.

ALMEIDA, I. A.; CORREIA, J. R.; BRANCO, F. A.; GONILLA, J. A. Comportamento estrutural de painéis sanduíche compósitos para aplicações na indústria da construção $8^{\circ}$ Encontro Nacional de Mecânica Experimental - 21 - 23 de abril, 2010 - Guimarâes, Lisboa, Portugal (2010).

AMERICAN NATIONAL STANDARDS INSTITUTE - ANSI A208.1 (1999). Matformed wood particleboard: Specification. National Particleboard Association Gaithersburg, United States.

AMERICAN SOCIETY FOR TESTING AND MATERIALS - ASTM D1037 (2006) Standard Test Methods for Evaluating Properties of Wood-Base Fiber and Particle Panel Materials. Philadelphia, United States.

AMERICAN SOCIETY FOR TESTING AND MATERIALS - ASTM. ASTM E1530/2011: Standard test methods for evaluating the resistance to thermal transmission of material by the guarded heat flow meter technique. Philadelphia, 2011.

AMERICAN SOCIETY FOR TESTING AND MATERIALS - ASTM C393/C393M (2011) Standard Test Method for Core Shear Properties of Sandwich Constructions by Beam Flexure. Philadelfia, United States.

AMERICAN SOCIETY FOR TESTING AND MATERIALS - ASTM C271 (1999) Standard Test Method for Density of Core Materials. West Conshohocken, United States.

AMERICAN SOCIETY FOR TESTING AND MATERIALS (2009) - D30 Committe on Composite Materials. Route 291 \& Stewart Ave., MC P24-25, Ridley PA 19078, USA, 2009

ASSOCIAÇÃO BRASILEIRA DE NORMAS TÉCNICAS. NBR 14810: Painéis de partícula de média densidade. Rio de Janeiro, 2013a.

ASSOCIAÇÃO BRASILEIRA DE NORMAS TÉCNICAS. NBR 15498: Placas de fibrocimento sem amianto. Rio de Janeiro, 2016. 
ASSOCIAÇÃO BRASILEIRA DE NORMAS TÉCNICAS. NBR 11802: Pisos elevados Especificação. Rio de Janeiro, 1991.

ASSOCIAÇÃO BRASILEIRA DE NORMAS TÉCNICAS. NBR 15575-5: Edificações habitacionais - Desempenho Parte 4: Sistemas de vedações verticais internas e externas SVVIE. Rio de janeiro, $2013 \mathrm{~b}$.

ASSOCIAÇÃO BRASILEIRA DE NORMAS TÉCNICAS. NBR 15220: Desempenho térmico de edificações Parte 1: Definições, símbolos e unidades. Rio de Janeiro, 2003a.

ASSOCIAÇÃO BRASILEIRA DE NORMAS TÉCNICAS. NBR 15220: Desempenho térmico de edificações Parte 2: Métodos de cálculo da transmitância térmica, da capacidade térmica, do atraso térmico e do fator solar de elementos e componentes de edificações. Rio de Janeiro, 2003b.

ASSOCIAÇÃO BRASILEIRA DE NORMAS TÉCNICAS. NBR 15220: Desempenho térmico de edificações Parte 4: Medição da resistência térmica e da condutividade térmica pelo princípio da placa quente protegida. Rio de Janeiro, 2003c.

ASSOCIAÇÃO BRASILEIRA DE NORMAS TÉCNICAS. NBR 15220: Desempenho térmico de edificações Parte 5: Medição da resistência térmica e da condutividade térmica pelo método fluximétrico. Rio de Janeiro, 2003d.

ALMEIDA, M. I. A. Comportamento estrutural de painéis sanduíche compósitos para aplicações na indústria da construção. 2009. 185p. Dissertação (Mestrado) - Universidade Técnica de Lisboa, Lisboa, Portugal, 2009.

BALLESTEROS, J. E. M. Compósitos cimentícios reforçados com polpa celulósica tratada por hornificação para aplicação em construções rurais. 2014. 160p. Dissertação (Mestrado) - Faculdade de Zootecnia e Engenharia de Alimentos, Universidade de São Paulo, Pirassununga, 2014.

BENASSI, A. C. Caracterizações biométrica, química e sensorial de frutos de coqueiro variedade anã verde. 2006. Tese (Doutorado) - Universidade Estadual Paulista "Julio de Mesquita Filho" Faculdade de Ciências Agrárias e Veterinárias Campus de Jaboticabal, São Paulo, 2006.

BERTINI, A. A. Análise do comportamento à flexão de painéis sanduíche com faces de argamassa armada e núcleo de espuma rígida derivado de óleo de mamona. $1995.155 \mathrm{p}$. Dissertação (Mestrado) - Escola de Engenharia de São Carlos, Universidade de São Paulo, São Carlos, São Paulo, 1995.

BONILLA BUENO, S.; Chapas de partículas multicamadas com resíduos lignocelulósicos e resina PU de mamona. 2015. 91p. Dissertação (Mestrado) - Faculdade de Zootecnia e Engenharia de Alimentos, Universidade de São Paulo, Pirassununga, 2015.

BRASILIT SAINT-GOBAIN. Manual de montagem, 24p. São Paulo, 2013. Disponível em: $<$ http://www. basilit.com.br $>$. Acesso em: 13 de nov. 2017. 
BRITO, E. O.; SÁ-ROCHA, J. D.; VIDAURRE, G. B.; BATISTA, D. C.; PASSO, P. R.; MARQUES, L. G. C. Propriedades de chapas produzidas com resíduos do fruto de coco e partículas de pinus. Revista Floresta e Ambiente. v. 11, n. 2, p. 01 - 06, 2004.

BUENO, C. Avaliação de Ciclo de Vida na Construção Civil: análise de sensibilidade. 2014. 268 p. Tese - Instituto de Arquitetura e Urbanismo, Universidade de São Paulo, São Carlos, 2014.

CAMILLO, M. G. D. Análise da utilização de chapas e placas industrializadas nas vedações verticais internas em construções residenciais na região sul do brasil. 2010. 126 p. Dissertação (Mestrado) - Universidade Federal de Santa Catarina, Florianópolis, Santa Catarina, 2010.

CANTERI, M. G.; ALTHAU, R. A.; FILHO, J. S. DAS V.; GIGLIOTI, E. A.; GODOY, C. V. SASM-AGRI: Sistema para análise e separação de médias em experimentos agrícolas pelos métodos Scott-knott, Tukey e Duncan. Revista Brasileira de Agrocomputação, v.1, n.2, p.18-24, Dez., Ponta Grossa, Paraná, 2001.

COLli, A.; VITAL, B. R.; CARNEIRO, A. C. O.; SILVA, J. C.; CARVALHO, A. M. M. L.; LUCIA, R. M. D. Propriedade de chapas fabricadas com partículas de fibras paricá (Schizolobium amazonicum Huber ex. ducke) e fibras de coco. Revista Árvore, Viçosa, v. 34, n. 2, p. 333-338, 2010.

COMPOSITE PANEL ASSOCIATION. Buyers Guide 2018-2019, 8p. Wisconsin, USA. Disponível em: <www.compositepanel.org/userfiles/filemanager/4758/>. Acesso em: $16 \mathrm{de}$ nov. 2018.

CRAVO, J. C. M. Compósito particulado de baixa densidade com casca de amendoim, fibra de coco verde e resina poliuretana à base de óleo de mamona para aplicação como forro de galpões avícolas. 2013. 166 p. Dissertação (Mestrado) - Faculdade de Zootecnia e Engenharia de Alimentos, Universidade de São Paulo, Pirassununga, 2013.

CRUZ, F. Q. Desenvolvimento e caracterização de painéis sanduíche híbridos para a reabilitação de pisos de edifícios. 2017. 244p. Dissertação (Mestrado) - Universidade do Minho, Braga/Guimarães, Portugal, 2017.

CURTOLO, D. D.; FIORELli, J.; RAMOS, R. D.; SAYAMA, J. T. Fabricação de compósitos de partículas com fibra do coco verde. $19^{\circ}$ Simpósio internacional de iniciação científica. 2011 Piracicaba-SP.

EMPRESA BRASILEIRA DE PESQUISA AGROPECUÁRIA - EMBRAPA. Disponível em: $<$ https://www.embrapa.br/agroindustria-tropical/busca-de-solucoes-tecnologicas/-/produtoservico/33/beneficiamento-da-casca-de-coco-verde-para-a-producao-de-fibra-e-po $>$. Acesso em: 12 ago. 2017

ESCOLA DE ENGENHARIA DE SÃO CARLOS - Painéis de Partículas de Madeira e de Materiais lignocelulósicos: Francisco Antonio Rocco Lahr e André Luis Christoforo - São Carlos: EESC/USP, 2013. 339 p. ISBN 978-85-8023-019-2. 
ETERNIT S.A. - DIVISÃO WALL. Painel wall Eternit, 4p. São Paulo, 2017. Disponível em: $<$ http://www.eternit.com.br>. Acesso em: 15 de nov. 2017.

DECORLIT INDÚSTRIA E COMÉRCIO LTDA. Produtos cimentícios, 12p. Leme, São Paulo, 2017. Disponível em: < http://www.decorlit.com.br>. Acesso em: 15 de nov. 2017.

FERREIRA, D. M. Comportamento estrutural em serviço e à rotura de painéis sanduiche compósitos. 2012. 174p. Dissertação (Mestrado) - Universidade Técnica de Lisboa, Lisboa, Portugal, 2012.

FIORELLI, J. Desenvolvimento, produção e caracterização de painéis de partículas lignocelulósicas de resíduos agroindustriais. 2013. $161 \mathrm{f}$. Livre docência - Faculdade de Zootecnia e Engenharia de Alimentos, Universidade de São Paulo, Pirassununga, 2013.

FIORELLI, J. ; GOMIDE, C. A.; LAHR, F. A. R.; NASCIMENTO, M. F.; BUENO, S. B.; SARTORI, D. L; BALESTEROS, J. E. M; BELINI, U. L. Physico-chemical and anatomical characterization of residual lignocellulosic fibers. Cellulose, v. 21. , n.5, p 3269-3277, ago. 2014.

FIORELLI, J.; CHRISTOFORO, A. L.; LAHR, F. A. R.; NASCIMENTO, M. F.; CURTOLO, D. D.; SARTORI, D. L; BELINI, U. L. Painéis de partículas monocamadas fabricados com resíduo de madeira e fibra de coco verde. Scientia Florestalis, v. 43, n.105, mar. 2015.

FONTANELlE, J. H.; AGOPYAN, V. A mobilidade dos sistemas de fixação de placas cimentícias destinadas a vedações externas. XVI ENTAC - Encontro Nacional de Tecnologia do Ambiente Construído - 29 a 31 de outubro, 2012- Juiz de fora. Minas Gerais, (2012).

GAGLIARDO, D. P. Análise de estruturas sanduíche: parâmetros de projeto. Campinas, 2008.166p. Dissertação (Mestrado em Estruturas) - Faculdade de Engenharia Civil, Arquitetura e Urbanismo, Universidade Estadual de Campinas, 2008.

GAGLIARDO, D. P.; MASCIA, N. T. Análise de estruturas sanduíche. Ambiente construído, v.10, n.4, p.247-258, 2010.

GARZON BARRERO, N. Estudo de durabilidade de painéis de partículas de bagaço de cana de açúcar e resina poliuretana à base de óleo de mamona para aplicação na construção civil. 2015. 231f Tese (Doutorado)- Faculdade de Zootecnia e Engenharia de Alimentos, Universidade de São Paulo, Pirassununga, 2015.

GOMES, T. S.; VISCONTE, L. L. Y.; PACHECO, E. B. A. V. Substituição da fibra de vidro por fibra de bananeira em compósitos de polietileno de alta densidade. Parte 1. Avaliação mecânica e térmica. Polímeros, vol. 23, n. 2, p. 206-211, 2013.

GUEDES, T. A.; MARTINS A. B. T.; ARCOSI L. R. C.; JANEIRO, V. Estatística descritiva: Projeto de ensino aprender fazendo estatística. Maringá: Universidade Estadual de Maringá, Departamento de Estatística; acesso 12 junho 2018. Disponível em: $<$ http://www.des.uem.br/Projetos/Estatistica_Descritiva.pdf $>$. 
GYPSUM DRYWALL. Guia de produtos, 24p. São Paulo, 2017. Dísponivel em: $<$ http://www.gypsum.com.br>. Acesso em: 14 de nov. 2017.

GUIA DE SISTEMAS PARA PRODUTOS PLANOS, 2011. Disponível em: $<$ http://www.basilit.com.br $>$. Acesso em: 13 de nov. 2017.

HOLANDA, E. P. T. Novas tecnologias construtivas para a produção de vedações verticais: diretrizes para o treinamento de mão de obra. 2003. $174 \mathrm{f}$. Dissertação (Mestrado) Departamento de Engenharia de Construção Civil da Escola Politécnica da USP.

INSTITUTO BRASILEIRO DE GEOGRAFIA E ESTATÍSTICA - IBGE. Disponível em: https://sidra.ibge.gov.br/tabela/6588\#resultado. Acesso em: 12 ago. 2017.

INSTITUTO BRASILEIRO DE SIDERÚRGIA/CENTRO BRASILEIRO DA CONSTRUÇÃO EM AÇO - IBS/CBCA, 2004. Manual de Construção em Aço: Painéis de vedação, $2^{\mathrm{a}}$ edição, 58p. Rio de Janeiro, Rio de Janeiro, 2004.

IWAKIRI, S. A influência d variáveis de processamento sobre propriedades das chapas de partículas de diferentes espécies de Pinus. $130 \mathrm{f}$. Tese (Doutorado em Ciências Florestais) - Setor de Ciências Agrárias, Universidade Federal do Paraná, Curitiba, 1989.

IWAKIRI, S. Painéis de Madeira Reconstituída. Ed. Ajir Gráfica e Editora Ltda, 2005. 247p. FUPEF - Fundação de Pesquisas Florestais do Paraná, 2005.

IWAKIRI, S. Produção de painéis de madeira aglomerada de Grevillea robusta. Revista Árvore, Viçosa, v. 28, n. 6, p. 883-887, 2004.

KNAUF INSULATION S.L. Ficha técnica, 2p. Barcelona 2014. Parque empresarial Mas Blau, Barcelona 2014.

LANA, A.M.Q.; SOARES NETO, J.; ALMEIDA, F. Q.; REZENDE, A. S. C. ; PRATES, R. C. Classificação de coeficientes de variação na experimentação com nutrição de equinos. Arquivo Brasileiro de Medicina Veterinária e Zootecnia, v.58, n.5, p.854-859, 2006.

LARROCA, C. Habitação social em madeira: Uma alternativa viável. 2002. 199p. Dissertação (Mestrado) - Universidade federal do Paraná, Engenharia Florestal do Setor de Ciências Agrárias, Curitiba, 2002.

LINUL, E.; MARSAVINA, L. Assesment of sandwich beams with rigid polyurethane foam core using failure-mode maps. Proceedings of the Romanian Academy, Series A, v.16, n.4, p 522-530, 2015.

LP BUILDING PRODUCTS. Catálogo técnico LP mezanino, 4p. Curitiba, Paraná 2012.

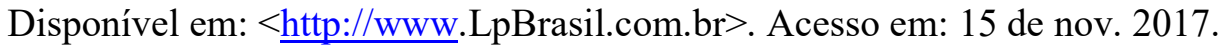

MANOLO, A. Fibre reinforced polymer composites sandwich structure: Recent developments and applications in civil infrastructure. 2013. Centre of Excellence in 
Engineered Fibre Composites, Faculty of Health, Engeneering and Sciences, |University of Southern Queensland, Australia, 2013.

MENDES, L. M.; ALBUQUERQUE, C. E. C.; IWAKIRI, S. A indústria brasileira de painéis de madeira. Revista da Madeira, v. 1, n. 71, p. 12-12, 2003.

MOHALlEM, D. F.; TAVARES, M.; SILVA, P. L.; GUIMARÃES, E. C; FREITAS, R. F. Avaliação do coeficiente de variação como medida da precisão em experimentos com frangos de corte. Arquivo Brasileiro de Medicina Veterinária e Zootecnia, v.60, n.2, p.449-453, 2008 .

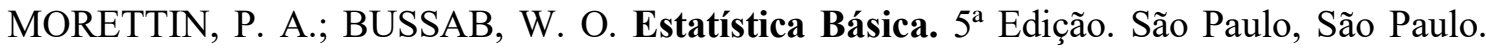
Editora Saraiva, 2004. 537p. ISBN 85-02-03497-9.

MOTTA, L. A. DE C.; GONÇALVES, L. K. DE S.; SILVA, M. S DA; CUNHA, J.; DANTAS, M E Painéis sanduíches de poliéster reforçado com fibras de rami para aplicação na Construção Civil. Revista Matéria, ISSN 1517-7076 ARTIGO 11745, P. 796-806, 2016.

MUNIZ, J. A.; JUDICE, M. G.; CARVALHEIRO, R. Avaliação do coeficiente de variação na experimentação com suínos. Ciênc. e Agrotec., v.23, n.1, p.170-173, jan./mar., 1999.

NASCIMENTO, M. F.; LAHR, F. A. R.; CHRISTOFORO, A. L.; BERTOLINI, M. DA S.; CHAHUD, E. Painéis de partículas homogêneas fabricados com espécies de manejo da região da Caatinga do Brasil. Construindo, Belo Horizonte, v. 5, n. 2, p. 1-10, Jul/Dez. 2013.

NOGUEIRA DE Ó, H. M. B. Comportamento de vigas sandwich de secção em caixa sujeitas a flexão: Vigas para aplicação em mobiliário construídas com compósitos de madeira. 2009. 107p. Dissertação (Mestrado) - Universidade Técnica de Lisboa, Lisboa, Portugal, 2009.

NOGUEIRA, J. R. da S.; CALLEJAS, I. J. A.; DURANTE, L. C. Desempenho de painel de vedação vertical externa em Light Steel Framing composto por placas de madeira mineralizada. Ambiente Construído, Porto Alegre, v. 18, n. 3, p. 289-307, jul./set. 2018. ISSN 1678-8621 Associação Nacional de Tecnologia do Ambiente Construído.

PASSOS, P. R. A. Destinação sustentável de cascas de coco verde (Cocos nucifera): obtenção de telhas e chapas de partículas. Rio de Janeiro, 2005. 166p. (Tese de Doutorado, COPPE/UFRJ).

PATINHA, S. M. P. A. Construção Modular - Desenvolvimento da ideia: Casa numa caixa. 2011. 184p. Dissertação (Mestrado) - Universidade de Aveiro, Aveiro, Portugal, 2011.

POLETO, S. F. S.; MORALES, E. A. M.; FERRO, F.; DIAS, F. M. Produção de painéis de partículas homogêneas (PPH) utilizando resíduos de espécies de reflorestamento - Painéis de Partículas de Madeira e de Materiais lignocelulósicos. Escola de Engenharia de São Carlos: EESC/USP, 2013. 339 p. ISBN 978-85-8023-019-2. 
SANTOS, M. C. S. Estabilidade e fenômenos de localização em elementos de painel sanduíche. 1994. 151f. Dissertação (Mestrado) - Departamento de Engenharia Civil, Universidade de Coimbra, Coimbra, 1994.

SCHMILDT, E. R.; SILVA, W.; AMBROSIO, T. DE J.; SCHMILDT, O.; NASCIMENTO, A. L; FERNANDES, A. A. Coeficiente de variação como medida da precisão em experimentos de alface. Revista Agro@mbiente On-line, ISSN 1982-8470, v. 11, n. 4, p. 290-295, outubro-dezembro, 2017.

PEREIRA, C. L. Aproveitamento do resíduo do coco verde para produção de compósitos destinados à construção rural. 2015. 231f. Tese (Doutorado). Faculdade de Zootecnia e Engenharia de Alimentos, Universidade de São Paulo, Pirassununga, 2015.

PEREIRA, D. V. Industrialização das construções complexas: estudo de obras hospitalares. 2012. 152 p. Dissertação (mestrado) - Instituto de Arquitetura e Urbanismo da Universidade de São Paulo, São Carlos, São Paulo, 2012.

PEREIRA, C.; SILVA, A.; BRITO, J.; SILVESTRE, J. D.; FLORES-COLEN, I. A previsão da vida útil de elementos construtivos como ferramenta de apoio a manutenção. $\mathbf{6}^{\mathbf{a}}$ Conferência sobre patologias e reabilitação de edifícios, 2018. 04-06 Abril, Poli/UFRJ, cidade Universitária, Rio de Janeiro.

PETERNELli, L. A. Capítulo 2: estatística descritiva. Material didático. s/d. Disponível em: $<$ http://www. dpi. ufv. br/ ${ }^{\sim}$ peternelli/inf162. www, v. 16032004, 2012.

PETRAS, A. Design of sandwich structures. 1998. 114p. Tese (Doutorado) - Robinson College, Cambridge University Engineering Department, 1998.

RILEM DRAFT RECOMMENDATIONS - Rilem Technical committee 49 trf: Testing methods for fibre reinforced cement based composites - Test for the determination of modulus of rupture and limit of proportionality of thin fibre reinforced cement sections.

RODRIGUES, C. F. S.; CAMELLO DE LIMA, F. J.; FABIANO, T. B. Importância do uso adequado da estatística básica nas pesquisas clínicas. Revista Brasileira Anestesiologia . 2017; v. 67(6), p.619-625.

SARTORI, D. L. Painel portante estrutural com chapa de partículas de bagaço de canade açúcar e resina de mamona para centro de manejo bovino 2012. 129 f. Dissertação (Mestrado) - Faculdade de Zootecnia e Engenharia de Alimentos, Universidade de São Paulo, Pirassununga, 2012.

SARTORI, D. L.; CRAVO, J. C. M.; BARRERO, N. G.; FIORELLI, J.; SAVASTANO JR, H. Painel em madeira de reflorestamento e chapas de partículas para instalações rurais. Revista Floresta e Ambiente, v.19, n.2, p.171-178, 2012.

SILVA, M. G. da.; SILVA, V. G. da. Painéis de vedação. - Rio de Janeiro: IBS/CBCA, (Série Manual de Construção em Aço). 59p. 2004. 
SOUZA. A. M. Introdução a projetos experimentais: caderno didático. 127p Universidade Federal de Santa Maria, Santa Maria, 2002.

TAGUCHI, M. K. Avaliação e qualificação das patologias das alvenarias de vedação nas edificações. 2008. 84 f. Dissertação (Mestrado) - Universidade Federal do Paraná, Setor de Tecnologia, Programa de Pós-Graduação em Construção Civil. Curitiba, 2008.

VERAS, M. A. Estudo, Fabrico e Caracterização de Painéis Sanduíche com Núcleos em Materiais Compósitos de Cortiça. 2013. 144 f. Dissertação (Mestrado) - Instituto Superior de Engenharia de Lisboa, Área Departamental de Engenharia Mecânica, Lisboa, 2013.

WAY, D. Proof of Concept for a Three-Dimensional Molded Core Wood Sandwich Panel. 2015. 123p. Dissertação (Mestrado) - Oregon State University, United State, 2015.

WAY, D.; SINHA, A.; ASCE, A. M.; KAMKE, F. A.; FUJI, J. S. Evaluation of a woodstrand molded core sandwich panel. Journal of Materials in Civil Engeneering, 2016, 28(9): 04016074. 